Prepared in cooperation with the California State Water Resources Control Board A product of the California Groundwater Ambient Monitoring and Assessment (GAMA) Program

\title{
Groundwater-Quality Data in the Borrego Valley, Central Desert, and Low-Use Basins of the Mojave and Sonoran Deserts Study Unit, 2008-2010: Results from the California GAMA Program
}

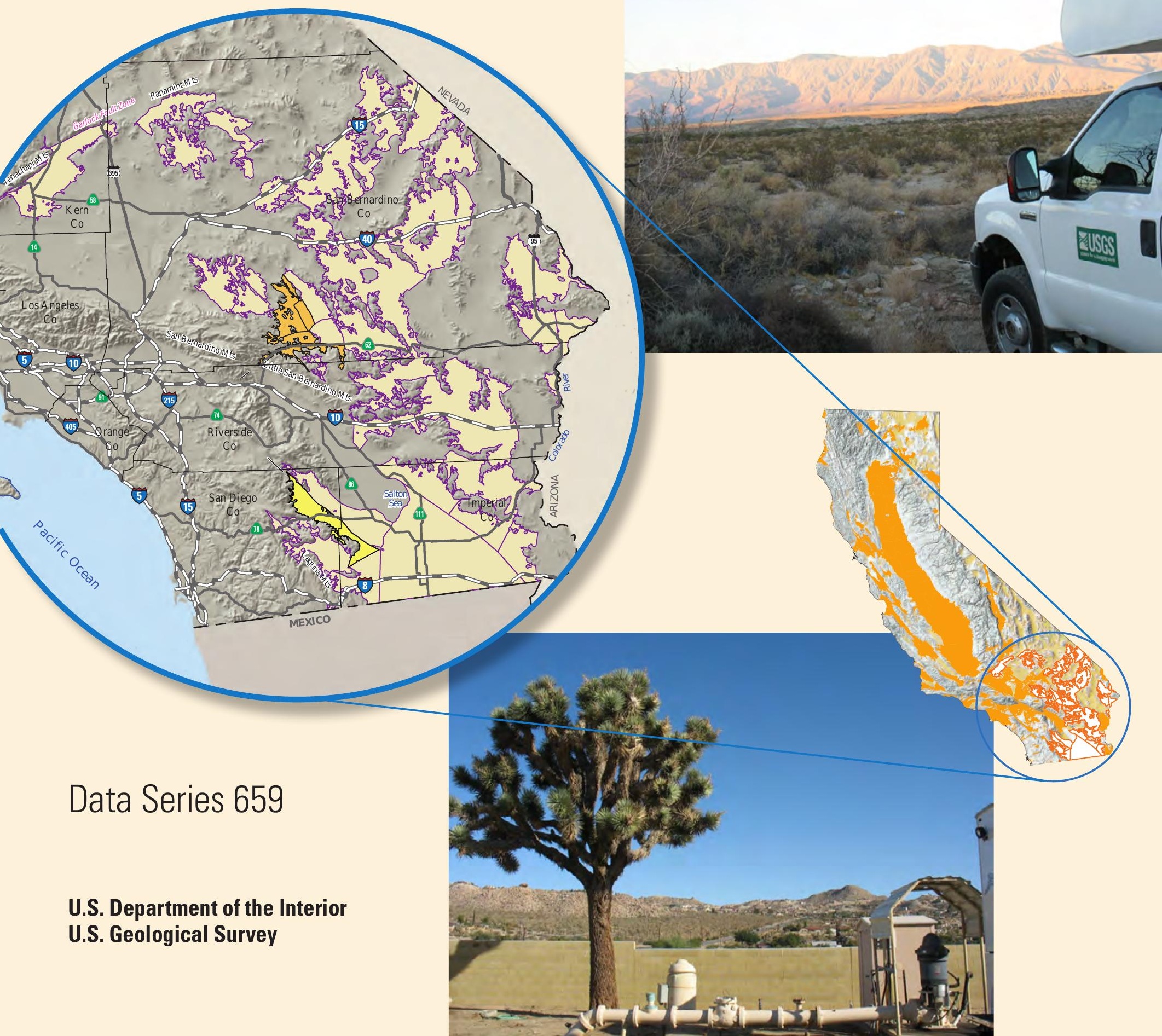


Top Right:

Borrego Valley at sunset, California. (Photograph taken by Michael Solt, U.S. Geological Survey)

Bottom:

Joshua Tree and public supply well, Yucca Valley, California. (Photograph taken by Dara Goldrath, U.S. Geological Survey) 


\section{Groundwater-Quality Data in the Borrego Valley, Central Desert, and Low-Use Basins of the Mojave and Sonoran Deserts Study Unit, 2008-2010: Results from the California GAMA Program}

By Timothy M. Mathany, Michael T. Wright, Brandon S. Beuttel, and Kenneth Belitz

A Product of the California Groundwater Ambient Monitoring and Assessment (GAMA) Program

Prepared in cooperation with the California State Water Resources Control Board

Data Series 659 


\title{
U.S. Department of the Interior \\ KEN SALAZAR, Secretary \\ U.S. Geological Survey \\ Marcia K. McNutt, Director
}

\author{
U.S. Geological Survey, Reston, Virginia: 2012
}

For more information on the USGS - the Federal source for science about the Earth, its natural and living resources, natural hazards, and the environment, visit http://www.usgs.gov or call 1-888-ASK-USGS.

For an overview of USGS information products, including maps, imagery, and publications, visit http://www.usgs.gov/pubprod

To order this and other USGS information products, visit http://store.usgs.gov

Any use of trade, product, or firm names is for descriptive purposes only and does not imply endorsement by the U.S. Government.

Although this report is in the public domain, permission must be secured from the individual copyright owners to reproduce any copyrighted materials contained within this report.

Suggested citation:

Mathany, T.M., Wright, M.T., Beuttel, B.S., and Belitz, Kenneth, 2012, Groundwater-quality data in the Borrego Valley, Central Desert, and Low-Use Basins of the Mojave and Sonoran Deserts study unit, 2008-2010—Results from the California GAMA Program: U.S. Geological Survey Data Series 659, 100 p. 


\section{Contents}

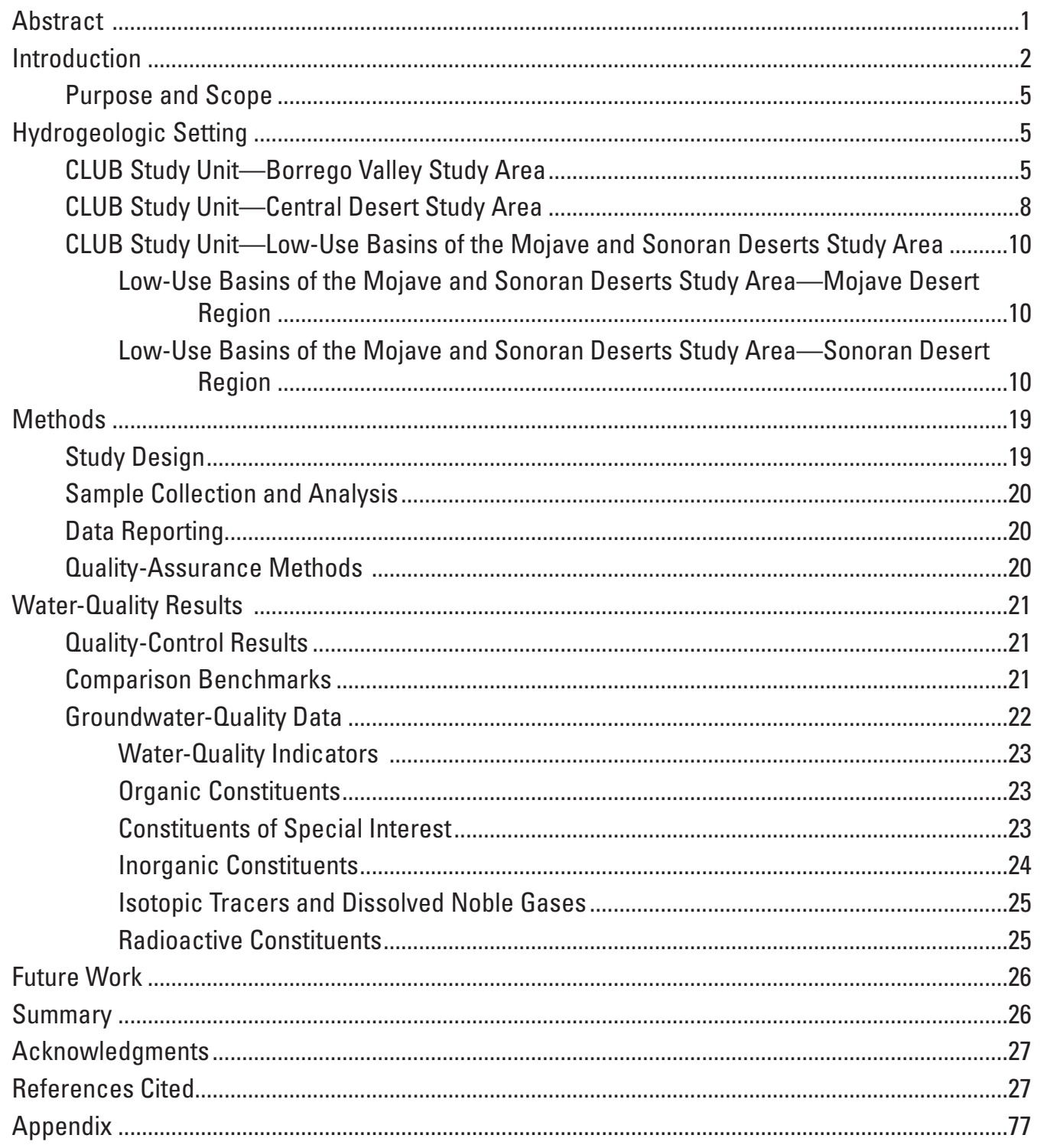




\section{Figures}

Figure 1. Map showing the hydrogeologic provinces of California and the location of the Borrego Valley, Central Desert, and Low-Use Basins of the Mojave and Sonoran Deserts (CLUB) Groundwater Ambient Monitoring and Assessment (GAMA) study unit and study areas.

Figure 2. Map showing the location of the Borrego Valley, Central Desert, and Low-Use Basins of the Mojave and Sonoran Deserts (CLUB) Groundwater Ambient Monitoring and Assessment (GAMA) study units

Figure 3. Map showing the Borrego Valley study area (BV), the boundaries of the California Department of Water Resources (CDWR) defined groundwater basins, the distribution of the Central Desert study area grid cells, the location of California Department of Public Health (CDPH) wells, and the location of sampled grid wells

Figure 4. Map showing the Central Desert study area (CD), the boundaries of the California Department of Water Resources (CDWR) defined groundwater basins, the distribution of the $\mathrm{CD}$ study area grid cells, the location of California Department of Public Health (CDPH) wells, and the location of sampled grid wells

Figure 5. Map showing the northwestern part, the northern part, the northeastern part, the western part, the central part, the eastern part, the southwestern part, and the southeastern part of the Low-Use Basins of the Mojave and Sonoran Deserts study area (LUB), the boundaries of the California Department of Water Resources (CDWR) defined groundwater basins, the distribution of the LUB study-area grid cells, the location of California Department of Public Health (CDPH) wells, and the location of sampled grid and understanding wells ... 11

\section{Tables}

Table 1. Identification, sampling, and construction information for wells sampled for the Borrego, Central Desert, and Low-Use Basins of the Mojave and Sonoran Deserts (CLUB) Groundwater Ambient Monitoring and Assessment (GAMA) study, California, December 2008 to March 2010.

Table 2. Classes of chemical constituents and water-quality indicators collected for the slow and the fast well sampling schedules in the Borrego, Central Desert, and Low-Use Basins of the Mojave and Sonoran Deserts (CLUB) Groundwater Ambient Monitoring and Assessment (GAMA) study, California, December 2008 to March 2010

Table 3A. Volatile organic compounds (VOCs), primary uses or sources, comparative benchmarks, and reporting information for the U.S. Geological Survey (USGS) National Water Quality Laboratory (NWOL) Schedule 2020

Table 3B. Pesticides and pesticide degradates, primary uses or sources, comparative benchmarks, and reporting information for the U.S. Geological Survey (USGS) National Water Quality Laboratory (NWQL) Schedule 2003

Table 4. Water-quality indicators in samples collected for the Borrego Valley, Central Desert, and Low-Use Basins of the Mojave and Sonoran Deserts (CLUB) Groundwater Ambient Monitoring and Assessment (GAMA) study, California, December 2008 to March 2010 


\section{Tables-Continued}

Table 5. Volatile organic compounds (VOCs) detected in samples collected for the Borrego Valley, Central Desert, and Low-Use Basins of the Mojave and Sonoran Deserts (CLUB) Groundwater Ambient Monitoring and Assessment (GAMA) study, California, December 2008 to March 2010.

Table 6. Pesticides and pesticide degradates detected in samples collected for the Borrego Valley, Central Desert, and Low-Use Basins of the Mojave and Sonoran Deserts (CLUB) Groundwater Ambient Monitoring and Assessment (GAMA) study, California, December 2008 to March 2010.

Table 7. Perchlorate detected in the samples collected for the Borrego Valley, Central Desert, and Low-Use Basins of the Mojave and Sonoran Deserts (CLUB) Groundwater Ambient Monitoring and Assessment (GAMA) study, California, December 2008 to March 2010

Table 8. Trace elements detected in the samples collected for the Borrego Valley, Central Desert, and Low-Use Basins of the Mojave and Sonoran Deserts (CLUB) Groundwater Ambient Monitoring and Assessment (GAMA) study, California, December 2008 to March 2010

Table 9. Nutrients detected in samples collected for the Borrego Valley, Central Desert, and Low-Use Basins of the Mojave and Sonoran Deserts (CLUB) Groundwater Ambient Monitoring and Assessment (GAMA) study, California, December 2008 to March 2010

Table 10. Major and minor ions, silica, and total dissolved solids (TDS) detected in samples collected for the Borrego Valley, Central Desert, and Low-Use Basins of the Mojave and Sonoran Deserts (CLUB) Groundwater Ambient Monitoring and Assessment (GAMA) study, California, December 2008 to March 2010.

Table 11. Species of inorganic chromium detected in samples collected for the Borrego Valley, Central Desert, and Low-Use Basins of the Mojave and Sonoran Deserts (CLUB) Groundwater Ambient Monitoring and Assessment (GAMA) study, California, December 2008.

Table 12. Hexavalent chromium (chromium-VI, Cr-VI) detected in samples collected for the Borrego Valley, Central Desert, and Low-Use Basins of the Mojave and Sonoran Deserts (CLUB) Groundwater Ambient Monitoring and Assessment (GAMA) study, California, October 2009 to March 2010.

Table 13. Results for analyses of stable isotope ratios, tritium activity, and carbon-14 abundance detected in samples collected for the Borrego Valley, Central Desert, and Low-Use Basins of the Mojave and Sonoran Deserts (CLUB) Groundwater Ambient Monitoring and Assessment (GAMA) study, California, December 2008 to March 2010

Table 14A. Radon-222 detected in samples collected for the Borrego Valley, Central Desert, and Low-Use Basins of the Mojave and Sonoran Deserts (CLUB) Groundwater Ambient Monitoring and Assessment (GAMA) study, California, December 2008 to March 2010.

Table 14B. Radium isotopes detected in samples collected for the Borrego Valley, Central Desert, and Low-Use Basins of the Mojave and Sonoran Deserts (CLUB) Groundwater Ambient Monitoring and Assessment (GAMA) study, California, December 2008 to March 2010

Table 14C. Gross alpha and beta radioactivity detected in samples collected for the Borrego Valley, Central Desert, and Low-Use Basins of the Mojave and Sonoran Deserts (CLUB) Groundwater Ambient Monitoring and Assessment (GAMA) study, California, December 2008 to March 2010 


\section{Conversion Factors and Datums}

Conversion Factors

Inch/Pound to SI

\begin{tabular}{lll}
\hline \multicolumn{1}{c}{ Multiply } & \multicolumn{1}{c}{ By } & \multicolumn{1}{c}{ To obtain } \\
\hline inch (in.) & 2.54 & centimeter $(\mathrm{cm})$ \\
foot (ft) & 0.3048 & meter $(\mathrm{m})$ \\
mile $(\mathrm{mi})$ & 1.609 & kilometer $(\mathrm{km})$ \\
square mile $\left(\mathrm{mi}^{2}\right)$ & 2.590 & square kilometer $\left(\mathrm{km}^{2}\right)$ \\
quart (qt) & 0.9464 & liter $(\mathrm{L})$ \\
pound, avoirdupois $(\mathrm{lb})$ & 0.4536 & kilogram $(\mathrm{kg})$ \\
\hline
\end{tabular}

SI to Inch/Pound

\begin{tabular}{lll}
\hline \multicolumn{1}{c}{ Multiply } & \multicolumn{1}{c}{ By } & \multicolumn{1}{c}{ To obtain } \\
\hline centimeter $(\mathrm{cm})$ & 0.3937 & inch $(\mathrm{in})$. \\
micrometer $(\mu \mathrm{m})$ & $3.3 \times 10^{-6}$ & foot $(\mathrm{ft})$ \\
kilometer $(\mathrm{km})$ & 0.6214 & mile $(\mathrm{mi})$ \\
square kilometer $\left(\mathrm{km}^{2}\right)$ & 0.3861 & square mile $\left(\mathrm{mi}^{2}\right)$ \\
liter $(\mathrm{L})$ & 1.0567 & quart $(\mathrm{qt})$ \\
gram $(\mathrm{g})$ & 0.03527 & ounce, avoirdupois $(\mathrm{oz})$ \\
kilogram $(\mathrm{kg})$ & 2.205 & pound, avoirdupois $(\mathrm{lb})$ \\
\hline
\end{tabular}

Temperature in degrees Celsius $\left({ }^{\circ} \mathrm{C}\right)$ may be converted to degrees Fahrenheit $\left({ }^{\circ} \mathrm{F}\right)$ as follows:

$$
{ }^{\circ} \mathrm{F}=\left(1.8 \times{ }^{\circ} \mathrm{C}\right)+32 .
$$

Specific conductance is given in microsiemens per centimeter at 25 degrees Celsius $(\mu \mathrm{S} / \mathrm{cm}$ at $\left.25^{\circ} \mathrm{C}\right)$.

Concentrations of chemical constituents in water are given either in milligrams per liter (mg/L) or micrograms per liter $(\mu \mathrm{g} / \mathrm{L})$.

Milligrams per liter is equivalent to parts per million (ppm), and micrograms per liter is equivalent to parts per billion (ppb).

Concentrations of radioactive constituents in water are given in picocuries per liter ( $\mathrm{pCi} / \mathrm{L})$.

Datums

Vertical coordinate information is referenced to the North American Vertical Datum of 1988 (NAVD 88).

Horizontal coordinate information is referenced to the North American Datum of 1983 (NAD 83).

Land-surface altitude, as used in this report, refers to distance above the vertical datum and is reported as feet above mean sea level ( $\mathrm{ft}$ above $\mathrm{msl}$ ) and feet below mean sea level (ft below $\mathrm{msl)}$. 


\section{Selected Terms and Symbols}

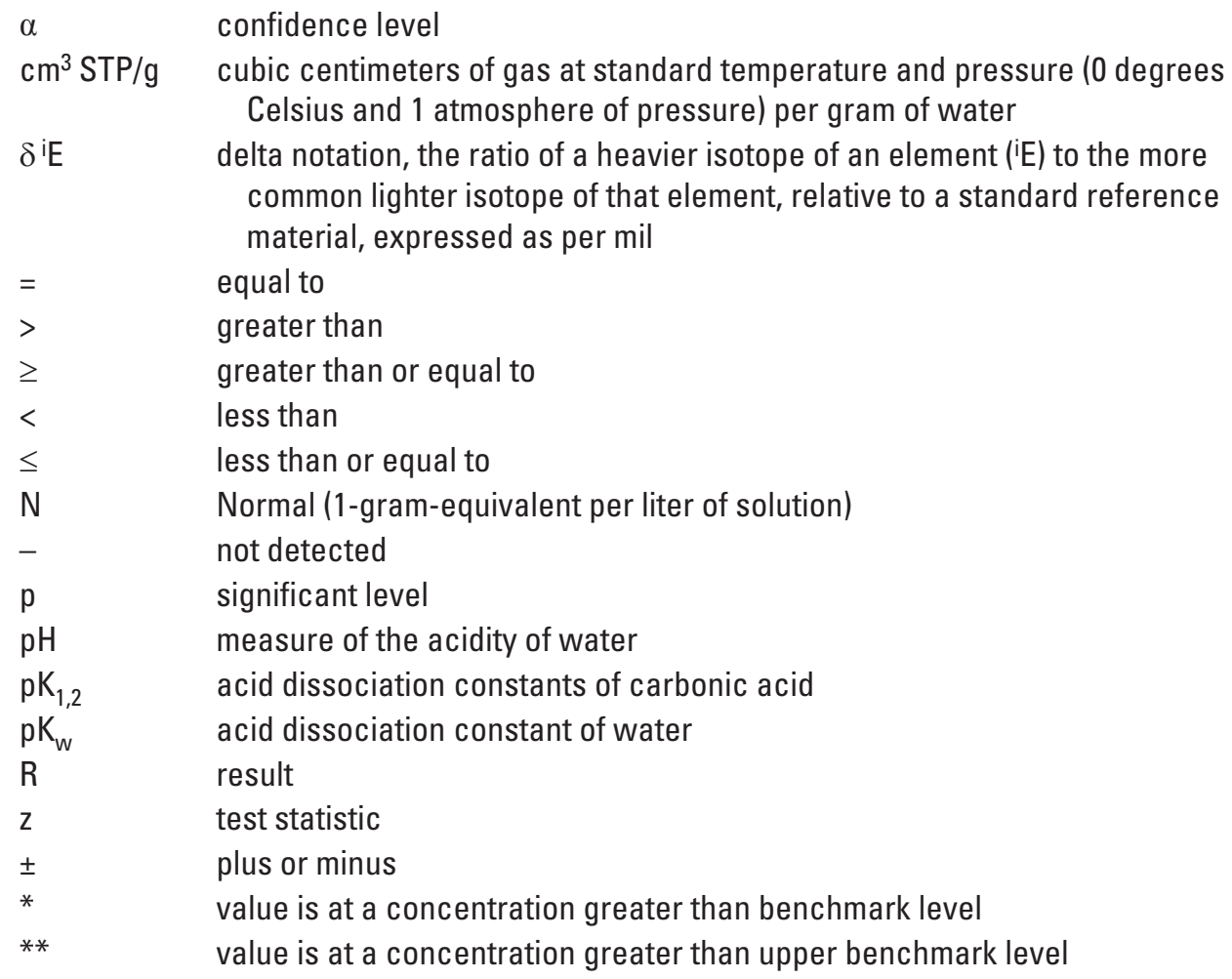

\section{Abbreviations and Acronyms}

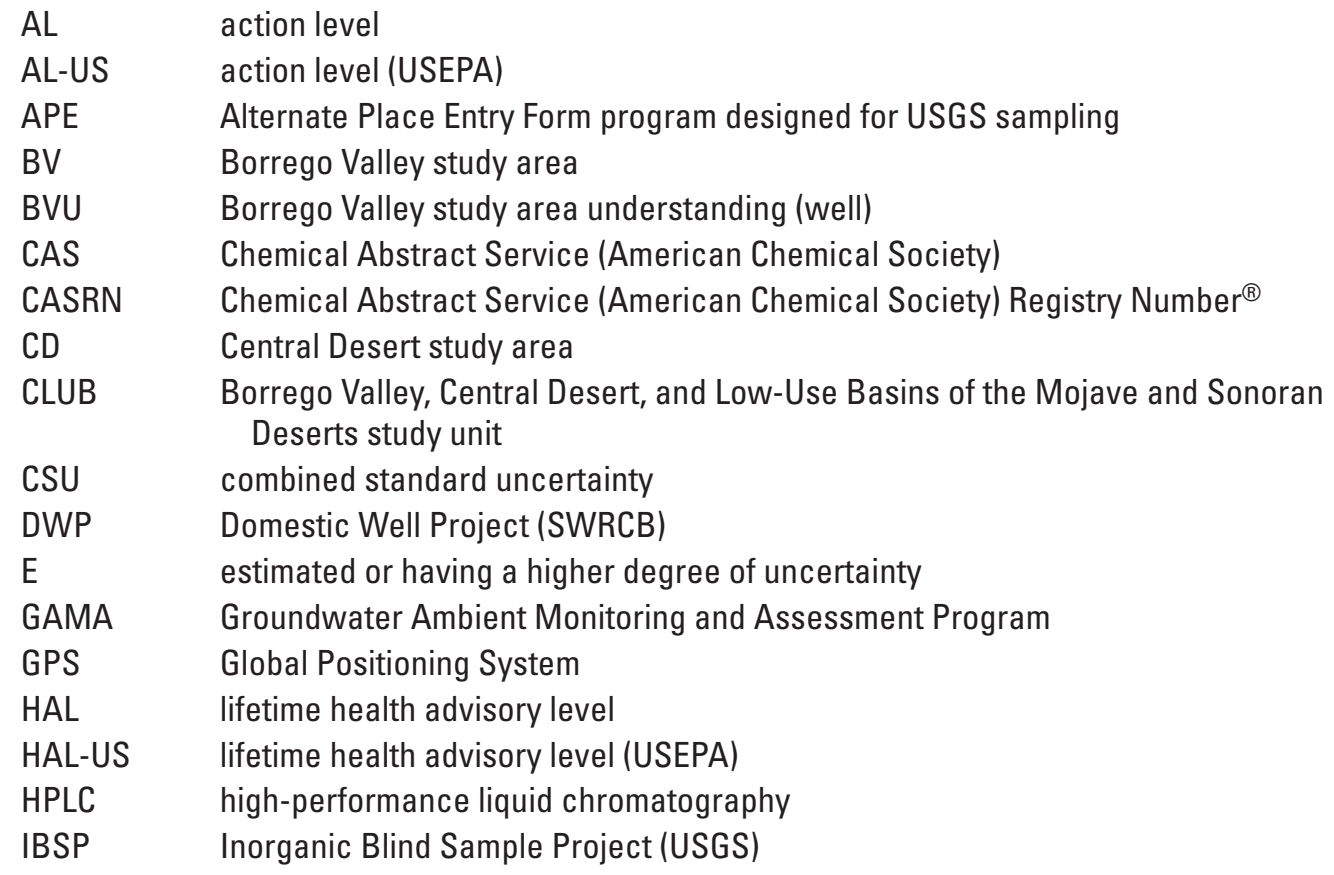




\title{
Abbreviations and Acronyms-Continued
}

\author{
LRL laboratory reporting level \\ LSD land surface datum \\ LT-MDL long-term method detection level \\ LUB Low-Use Basins of the Mojave and Sonoran Deserts study area \\ LUBU Low-Use Basins of the Mojave and Sonoran Deserts study area understanding \\ (well) \\ MCL maximum contaminant level \\ MCL-US maximum contaminant level (USEPA) \\ MCL-CA maximum contaminant level (CDPH) \\ MDL method detection limit \\ MRL minimum reporting level \\ MU method uncertainty \\ na not available \\ nc not collected \\ NELAP National Environmental Laboratory Accreditation Program \\ NFM National Field Manual (USGS) \\ NFOA National Field Quality Assurance Program (USGS) \\ NL notification level \\ NL-CA notification level (CDPH) \\ nv no measured value or no value in category \\ np no preference \\ NRP National Research Program (USGS) \\ NWIS National Water Information System (USGS) \\ OBSP Organic Blind Sample Program (USGS) \\ PBP Priority Basin Project \\ PCFF Personal Computer Field Form program designed for USGS sampling \\ QA quality assurance \\ OC quality control \\ $\mathrm{RL} \quad$ reporting level \\ RPD relative percent difference \\ RSD relative standard deviation \\ RSD5 risk-specific dose at $10^{-5}$ (USEPA) \\ SD standard deviation \\ SMCL secondary maximum contaminant level \\ SMCL-CA secondary maximum contaminant level (CDPH) \\ SMCL-US secondary maximum contaminant level (USEPA) \\ SRL $\quad$ study reporting level (concentration cutoff for applying the $\leq$ symbol) \\ $\mathrm{ssL}_{\mathrm{C}} \quad$ sample-specific critical level \\ U.S. United States \\ UV ultraviolet \\ VPDB Vienna Pee Dee Belemnite (the international reference standard for carbon \\ isotopes) \\ VSMOW Vienna Standard Mean Ocean Water (an isotopic water standard defined in 1968 \\ by the International Atomic Energy Agency)
}




\title{
Abbreviations and Acronyms - Continued
}

\section{Organizations}

\author{
BOS Branch of Quality Systems (USGS) \\ $\mathrm{CDPH} \quad$ California Department of Public Health \\ CDPR California Department of Pesticide Regulation \\ CDWR California Department of Water Resources \\ LLNL Lawrence Livermore National Laboratory \\ NAWQA National Water-Quality Assessment Program (USGS) \\ NIST National Institute of Standards and Technology \\ NWQL National Water Quality Laboratory (USGS) \\ SITL Stable Isotope and Tritium Laboratory, Menlo Park, California (USGS) \\ SWRCB California State Water Resources Control Board \\ TALIR TestAmerica Laboratories, Inc., Irvine, California \\ TML Trace Metal Laboratory, Boulder, Colorado (USGS) \\ USEPA U.S. Environmental Protection Agency \\ USGS U.S. Geological Survey
}

\section{Selected Chemical Names}

$\begin{array}{ll}\mathrm{CaCO}_{3} & \text { calcium carbonate } \\ \mathrm{CO}_{3}^{2-} & \text { carbonate } \\ \mathrm{CFC} & \text { chlorofluorocarbon } \\ \mathrm{Cr}-\mathrm{VI} & \text { hexavalent chromium (chromium-VI) } \\ \mathrm{DIPE} & \text { diisopropyl ether } \\ \mathrm{H}_{2} \mathrm{O} & \text { water } \\ \mathrm{HCl} & \text { hydrochloric acid } \\ \mathrm{HCO}_{3}^{-} & \text {bicarbonate } \\ \mathrm{MTBE} & \text { methyl tert-butyl ether } \\ \mathrm{NDMA} & \mathrm{N} \text {-nitrosodimethylamine } \\ \mathrm{PCE} & \text { perchloroethene (tetrachloroethene) } \\ \mathrm{PVC} & \text { polyvinyl chloride } \\ \mathrm{SiO} & \text { silicon dioxide } \\ \mathrm{TCE} & \text { trichloroethene } \\ \mathrm{TDS} & \text { total dissolved solids } \\ \text { THM } & \text { trihalomethane } \\ \text { VOC } & \text { volatile organic compound }\end{array}$


This page intentionally left blank 


\title{
Groundwater-Quality Data in the Borrego Valley, Central Desert, and Low-Use Basins of the Mojave and Sonoran Deserts Study Unit, 2008-2010: Results from the California GAMA Program
}

\author{
By Timothy M. Mathany, Michael T. Wright, Brandon S. Beuttel, and Kenneth Belitz
}

\section{Abstract}

G roundwater quality in the 12,103-square-mile Borrego Valley, Central Desert, and L ow-U se B asins of the M ojave and Sonoran Deserts (CLUB) study unit was investigated by the U.S. Geological Survey (USGS) from December 2008 to $M$ arch 2010, as part of the California State Water Resources Control Board (SWRCB) Groundwater A mbient M onitoring and A ssessment (GA M A) Program's Priority Basin Project (PBP). The GAM A -PBP was developed in response to the California G roundwater Quality M onitoring A ct of 2001 and is being conducted in collaboration with the SWRCB and L aw rence Livermore National Laboratory (LLNL). The CLUB study unit was the twenty-eighth study unit to be sampled as part of the GAMA-PBP.

The GAMA CLUB study was designed to provide a spatially unbiased assessment of untreated-groundwater quality in the primary aquifer systems, and to facilitate statistically consistent comparisons of untreated-groundwater qual ity throughout California. The primary aquifer systems (hereinafter referred to as primary aquifers) are defined as parts of aquifers corresponding to the perforation intervals of wells listed in the California D epartment of Public H ealth (CDPH) database for the CLUB study unit. The quality of groundwater in shallow or deep water-bearing zones may differ from the quality of groundwater in the primary aquifers; shallow groundwater may be more vulnerable to surficial contamination.

In the CLUB study unit, groundwater samples were collected from 52 wells in 3 study areas (B orrego Valley, Central Desert, and Low-U se Basins of the M ojave and Sonoran Deserts) in San B ernardino, Riverside, K ern, San Diego, and Imperial Counties. Forty-nine of the wells were selected by using a spatially distributed, randomized grid-based method to provide statistical representation of the study unit (grid wells), and three wells were selected to aid in evaluation of water-quality issues (understanding wells).
The groundwater samples were analyzed for organic constituents (volatile organic compounds [V OCs], pesticides and pesticide degradates, and pharmaceutical compounds), constituents of special interest (perchlorate and $\mathrm{N}$-nitrosodimethylamine [NDM A]), naturally-occurring inorganic constituents (trace elements, nutrients, major and minor ions, silica, total dissolved solids [TDS], alkalinity, and species of inorganic chromium), and radioactive constituents (radon-222, radium isotopes, and gross alpha and gross beta radioactivity). Naturally-occurring isotopes (stable isotopes of hydrogen, oxygen, boron, and strontium in water, stable isotopes of carbon in dissolved inorganic carbon, activities of tritium, and carbon-14 abundance) and dissolved noble gases also were measured to help identify the sources and ages of sampled groundwater. In total, 223 constituents and 12 water-quality indicators were investigated.

Three types of quality-control samples (blanks, replicates, and matrix spikes) were collected at up to 10 percent of the wells in the CLUB study unit, and the results for these samples were used to evaluate the quality of the data for the groundwater samples. Field blanks rarely contained detectable concentrations of any constituent, suggesting that contamination from sample collection procedures was not a significant source of bias in the data for the groundwater samples. Replicate samples generally were within the limits of acceptable analytical reproducibility. $M$ edian matrix-spike recoveries were within the acceptable range (70 to 130 percent) for approximately 85 percent of the compounds.

This study did not attempt to evaluate the quality of water delivered to consumers; after withdrawal from the ground, untreated groundwater typically is treated, disinfected, and (or) blended with other waters to maintain water quality. Regulatory benchmarks apply to water that is delivered to the consumer, not to untreated groundwater. However, to provide some context for the results, concentrations of constituents measured in the untreated groundwater were compared with 
regulatory and non-regulatory health-based benchmarks established by the U.S. Environmental Protection A gency (USEPA) and CDPH, and to non-regulatory benchmarks established for aesthetic concerns by CDPH. Comparisons between data collected for this study and benchmarks for drinking water are for illustrative purposes only and are not indicative of compliance or non-compliance with those benchmarks.

M ost inorganic constituents detected in groundwater samples from the 49 grid wells were detected at concentrations less than drinking-water benchmarks. In addition, all detections of organic constituents from the CLUB study-unit grid-well samples were less than health-based benchmarks.

In total, V OCs were detected in 17 of the 49 grid wells sampled (approximately 35 percent), pesticides and pesticide degradates were detected in 5 of the 47 grid w ells sampled (approximately 11 percent), and perchlorate was detected in 41 of 49 grid wells sampled (approximately 84 percent).

Trace elements, major and minor ions, and nutrients were sampled for at 39 grid wells, and radioactive constituents were sampled for at 23 grid wells; most detected concentrations were less than health-based benchmarks. Exceptions in the grid-well samples include seven detections of arsenic greater than the USEPA maximum contaminant level (M CL-US) of 10 micrograms per liter $(\mu \mathrm{g} / \mathrm{L})$; four detections of boron greater than the CDPH notification level (NL-CA) of $1,000 \mu \mathrm{g} / \mathrm{L}$; six detections of molybdenum greater than the USEPA lifetime health advisory level (HAL-US) of $40 \mu \mathrm{g} / \mathrm{L}$; two detections of uranium greater than the M CL -US of $30 \mu \mathrm{g} / \mathrm{L}$; nine detections of fluoride greater than the CDPH maximum contaminant level ( $M C L-C A)$ of 2 milligrams per liter $(\mathrm{mg} / \mathrm{L})$; one detection of nitrite plus nitrate $\left(\mathrm{NO}_{2}{ }^{-}+\mathrm{NO}_{3}{ }^{-}\right)$, as nitrogen, greater than the M CL-US of $10 \mathrm{mg} / \mathrm{L}$; and four detections of gross alpha radioactivity (72-hour count), and one detection of gross al pha radioactivity (30-day count), greater than the MCL-US of 15 picocuries per liter.

Results for constituents with non-regulatory benchmarks set for aesthetic concerns showed that a manganese concentration greater than the CDPH secondary maximum contaminant level (SM CL-CA) of $50 \mu \mathrm{g} / \mathrm{L}$ was detected in one grid well. Chloride concentrations greater than the recommended SM CL-CA benchmark of $250 \mathrm{mg} / \mathrm{L}$ were detected in three grid wells, and one of these wells also had a concentration that was greater than the upper SM CL-CA benchmark of $500 \mathrm{mg} / \mathrm{L}$. Sulfate concentrations greater than the recommended SM CL -CA benchmark of $250 \mathrm{mg} / \mathrm{L}$ were measured in six grid wells. TDS concentrations greater than the SM CL-CA recommended benchmark of $500 \mathrm{mg} / \mathrm{L}$ were measured in 20 grid wells, and concentrations in 2 of these wells also were greater than the SM CL-CA upper benchmark of $1,000 \mathrm{mg} / \mathrm{L}$.

\section{Introduction}

A bout one-half of the water used for public and domestic drinking-water supply in California is groundwater (K enny and others, 2009). To assess the quality of ambient groundwater in aquifers used for public drinking-water supply and to establish a baseline groundwater-quality monitoring program, the California State Water Resources Control B oard (SW RCB) in cooperation with the U.S. Geological Survey (USGS) and L awrence Livermore N ational L aboratory ( $L L N L$ ) implemented the Groundwater A mbient M onitoring and A ssessment (GA M A) Program (California Environmental Protection A gency, 2011, website at http://www.waterboards. ca.gov/water issues/programs/gama/). The main goals of the GA M A Program are to improve groundwater monitoring and to increase the availability of groundwater-quality data to the public. The GA M A Program currently consists of three projects: (1) the GA M A Priority B asin Project (PBP) conducted by the USGS (U.S. Geological Survey, 2011a, California Water Science Center w ebsite at http://ca.water. usgs.gov/gama/); (2) the GAM A Domestic Well Project (DWP) conducted by the SWRCB; and (3) GAM A Special Studies conducted by LLNL. The GAM A-PBP primarily focuses on the deep part of the groundwater resource, which is typically used for public drinking-water supply. The GAMA-DWP generally focuses on the shallow aquifer systems, which may be particularly at risk as a result of surficial contamination. The GAMA Special Studies Project focuses on using research methods to help explain the source, fate, transport, and occurrence of chemicals that can affect groundwater quality.

A II published and quality-assurance/quality-control (QA/QC) approved analytical data collected for the GAM A Program are stored in the web-based G eotracker Database (California State Water Resources Control B oard, 2009a, website at https://geotracker.waterboards.ca.gov/gama/). The Geotracker Database al so stores groundwater-quality data and related reports collected by other State agencies, such as the California Department of Public Health (CDPH), California D epartment of Water Resources (CDWR), and California Department of Pesticide Regulation (CDPR), and data collected by the SWRCB and Regional Boards from environmental monitoring wells at contaminated and (or) remediated sites.

The GA M A Program was initiated by the SWR RB in 2000 and later expanded by the Groundwater Quality M onitoring A ct of 2001 (State of California, 2001a,b; Sections 10780-10782.3 of the California Water Code, A ssembly Bill 599). The GA M A -PBP assesses groundwater quality in key groundwater basins that account for more than 90 percent 
of all groundwater in the State. For the GAM A-PBP, the USGS, in collaboration with the SWRCB, developed the monitoring plan to assess groundwater basins through direct and other statistically reliable sample approaches (B elitz and others, 2003; California State Water R esources Control B oard, 2003). A dditional partners in the GA M A -PBP include LLNL, CDPH, CDWR, CDPR, local water agencies, and well owners (Kulongoski and B elitz, 2004). Participation in the GAM A-PBP is entirely voluntary.

The GAM A-PBP is unique in California because it includes many chemical analyses that are not otherwise available in the statewide water-quality monitoring datasets. Groundwater samples collected for the GA M A -PBP are typically analyzed for approximately 300 chemical constituents using analytical methods with lower detection limits than required by the CDPH for regulatory monitoring of water from drinking-water wells. These analyses will be especially useful for providing an early indication of changes in groundwater quality. In addition, the GA M A -PBP analyzes samples for a suite of constituents more extensive than required by CDPH and for a suite of chemical and isotopic tracers for understanding hydrologic and geochemical processes. This understanding of groundwater composition is useful for identifying the natural and human factors affecting water quality. Understanding the occurrence and distribution of chemical constituents of significance to water quality is important for the long-term management and protection of groundwater resources.

The range of hydrologic, geologic, and climatic conditions in California must be considered in an assessment of groundwater quality. B elitz and others (2003) partitioned the State into 10 hydrogeologic provinces, each with distinctive hydrologic, geologic, and climatic characteristics: Cascades and M odoc Plateau, K lamath M ountains, N orthern Coast Ranges, Central Valley, Sierra N evada, Basin and Range, Southern Coast Ranges, Transverse Ranges and selected Peninsular Ranges, Desert, and San Diego Drainages (fig. 1). These 10 hydrogeologic provinces include groundwater basins and subbasins designated by the CDW R (California Department of Water Resources, 2003a). $G$ roundwater basins and subbasins generally consist of relatively permeable, unconsolidated deposits of alluvial or volcanic origin. Eighty percent of California's approximately 16,000 active and standby drinking-water wells listed in the statewide database maintained by the CDPH (hereinafter referred to as CDPH wells) are located in groundwater basins and subbasins within the 10 hydrogeologic provinces. Groundwater basins and subbasins were prioritized for sampling on the basis of the number of CDPH wells in the basin, with secondary consideration given to municipal groundwater use, agricultural pumping, the number of formerly leaking underground fuel tanks, and the number of registered pesticide applications (B elitz and others, 2003).
Of the 472 basins and subbasins designated by the CDWR, 116 priority basins were selected and grouped into 35 GA M A study units, representing approximately 95 percent of the CDPH wells in California. In addition, some areas outside of the defined groundwater basins were included in the nearest respective study unit to achieve representation of the 20 percent of the CDPH wells not located in the groundwater basins.

The data collected in each study unit is used for three types of water-quality assessments: (1) Status: assessment of the current quality of the groundwater resource;

(2) Understanding: identification of the natural and human factors affecting groundwater quality; and (3) Trends: detection of changes in groundwater quality over time (K ulongoski and Belitz, 2004). The assessments are intended to characterize the quality of groundwater in the primary aquifer systems of the study units, not the treated drinking water delivered to consumers by water purveyors. The primary aquifer systems (hereinafter referred to as primary aquifers) are defined as parts of aquifers corresponding to the perforation intervals of wells listed in the CDPH database for the study units. The CDPH database lists wells used for municipal and community drinking-water supplies, and includes wells from systems classified as non-transient (such as those in cities, towns, and mobile-home parks) and transient (such as those in schools, campgrounds, and restaurants). Collectively, the CDPH refers to these wells as "public-supply" wells. Groundwater quality in shallow or deep parts of the aquifer systems may differ from that in the primary aquifers. In particular, shallow groundwater may be more vulnerable to surface contamination. As a result, samples from shallow wells (such as many private domestic wells and environmental monitoring wells) can have greater concentrations of constituents (such as volatile organic compounds [V OCs] and nitrate) from anthropogenic sources than samples from wells screened in the underlying primary aquifers (L andon and others, 2010).

The B orrego Valley, Central Desert, and Low-U se $B$ asins of the $M$ ojave and Sonoran Deserts study unit (hereinafter referred to as the CLUB study unit) lies in the Desert hydrogeologic province as described by Belitz and others (2003) (fig. 1). Groundwater is a major source of public drinking-water supply for many of the cities located in the CLUB study unit (Water Education Foundation, 2006); therefore, the CLUB study unit was considered high priority for sampling to provide adequate representation of the $D$ esert hydrogeologic province. This USGS Data Series Report is the first in a series of reports presenting the water-quality data collected by the USGS in the CLUB study unit for the GA M A -PBP. Other Data Series Reports and additional reports addressing the status, understanding, and trends aspects of the water-quality assessments of each study unit are available from the U.S. Geological Survey (2011b) at http://ca.water. usgs.gov/projects/gama/includes/GAM A_publications.html. 


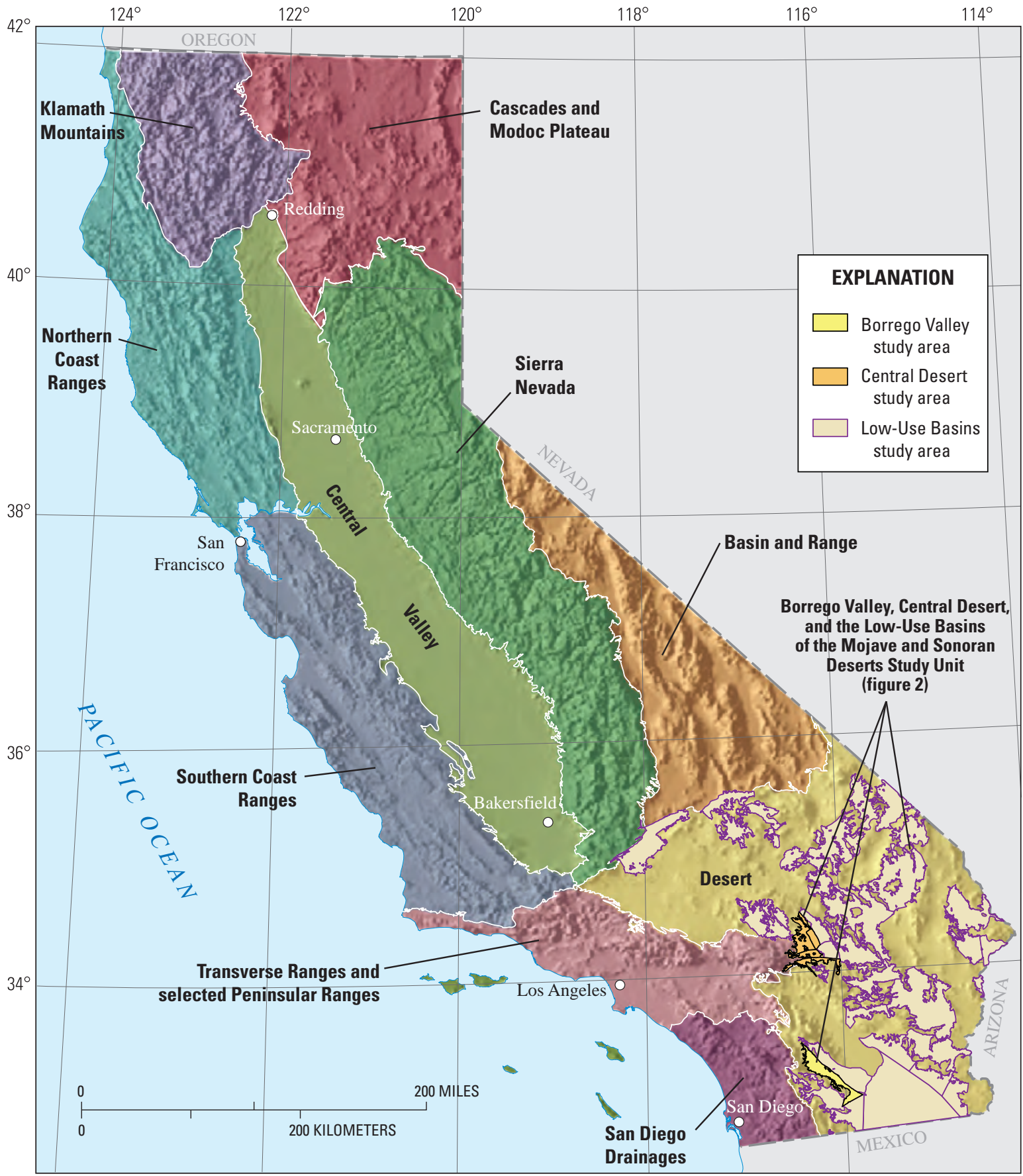

Shaded relief derived from U.S. Geological Survey

Provinces from Belitz and others, 2003.

National Elevation Dataset, 2006.

Albers Equal Area Conic Projection

Figure 1. The hydrogeologic provinces of California and the location of the Borrego Valley, Central Desert, and Low-Use Basins of the Mojave and Sonoran Deserts (CLUB) Groundwater Ambient Monitoring and Assessment (GAMA) study unit and study areas. 


\section{Purpose and Scope}

The purposes of this report are to describe (1) the study design, the hydrogeologic setting of the CLUB study unit, and the study methods; (2) the analytical results for groundwater samples collected in the CLUB study unit, and (3) the results of QC analyses. Groundwater samples were analyzed for water-quality indicators; organic, special-interest, inorganic, and radioactive constituents; naturally-occurring isotopes; and dissolved gases. The chemical data presented in this report were evaluated by comparison to State and Federal drinking-water regulatory and other non-regulatory standards that are applied to treated drinking water. Regulatory and non-regulatory benchmarks considered for this report are those established by the U.S. Environmental Protection A gency (USEPA) and (or) the CDPH. Discussion of the factors that influence the distribution and occurrence of the constituents detected in groundwater samples will be the subject of subsequent publications.

\section{Hydrogeologic Setting}

The CLU B study unit contains 47 groundwater basins and subbasins delineated by CDWR and is located in the South Lahontan and Colorado River hydrogeologic regions (C alifornia Department of Water Resources, 2003b,c, 2004a-ss). The three study areas (Borrego Valley, Central Desert, and Low-U se Basins of the M ojave and Sonoran Deserts) of the CLUB study unit cover an area of 12,103 square miles ( $\mathrm{mi}^{2}$ ) in San B ernardino, Riverside, K ern, San Diego, and Imperial Counties, California (fig. 2).

\section{CLUB Study Unit—Borrego Valley Study Area}

The B orrego Valley study area (hereinafter referred to as the BV study area) is $238 \mathrm{mi}^{2}$ in area and lies in the westernmost part of the Sonoran Desert, about 80 miles (mi) east of San Diego (fig. 2). The BV study area is located within the B orrego Valley groundwater basin (California D epartment of Water Resources, 2004a) and encompasses a large section of the A nza-B orrego Desert State Park. The study area is bounded on the west by the San Y sidro, Vallecito, Fish Creek, and Coyote M ountains and on the north by the Santa Rosa Mountains. The eastern boundary of the study area is defined by the Coyote Creek and Superstition M ountain faults. The southernmost border of the study area is a large unnamed wash that stretches from the Coyote M ountains northeast to Superstition M ountain (fig. 3).
L and-surface altitudes in the study area range from approximately 30 feet below mean sea level (ft below msl) in the L ower B orrego Valley, to over 4,500 feet above mean sea level (ft above msl) in the San Y sidro M ountains, located just west of the village of B orrego Springs. The major surface drainage features of the study area are the Coyote and San Felipe Creeks, both of which have their headwaters in the mountains to the north and west and drain to the Salton Sea. There is also a large surface drainage feature in the northern part of the study area named B orrego Sink, which is a major collection point for surficial runoff from Coyote Creek (fig. 3).

The climate in the study area is classified as subtropical desert (due to the land-surface altitude), with very hot summers and cool winters (PRISM Climate Group, 2010; U.S. D epartment of Commerce, National Climatic Data Center, 2010). Rainfall is predominantly derived from storms originating in the Pacific Ocean in the winter and to a lesser extent from the $\mathrm{N}$ orth A merican $\mathrm{M}$ onsoon, which is drawn northward through Mexico from the Pacific Ocean and (or) the Gulf of M exico in the summer (A dams, 1997). Average annual precipitation in the study area is less than 7 inches (in.) (PRISM Climate Group, Oregon State U niversity, 2010; Western Regional Climate Center, 2010).

The primary aquifer in the study area is the upper aquifer of a three-tiered alluvium-filled aquifer system that is underlain by crystalline bedrock. The upper aquifer is composed of alluvial, playa, eolian, and fan deposits of Holocene to Pleistocene age. The middle and lower aquifers consist of continental deposits of moderately consolidated gravel, sand, and boulders of Pleistocene age (California Department of Water Resources, 2004a).

The general groundwater-flow direction in the study area is from the western and northern sides of the study area toward the center, then southward, following the topography of the B orrego and L ower B orrego Valleys. The study area has two major northwest trending faults (Superstition M ountain and Coyote (reek), which act as hydrologic barriers to groundwater movement (California Department of Water Resources, 2004a) (fig. 3).

Groundwater recharge in the study area primarily occurs from the infiltration of runoff from the surrounding mountains into C oyote Creek, San F elipe Creek, and B orrego Sink. To a lesser extent, ambient recharge al so occurs from the seepage of small intermittent streams and washes originating from the mountains west and north of the study area (California Department of Water Resources, 2004a). 


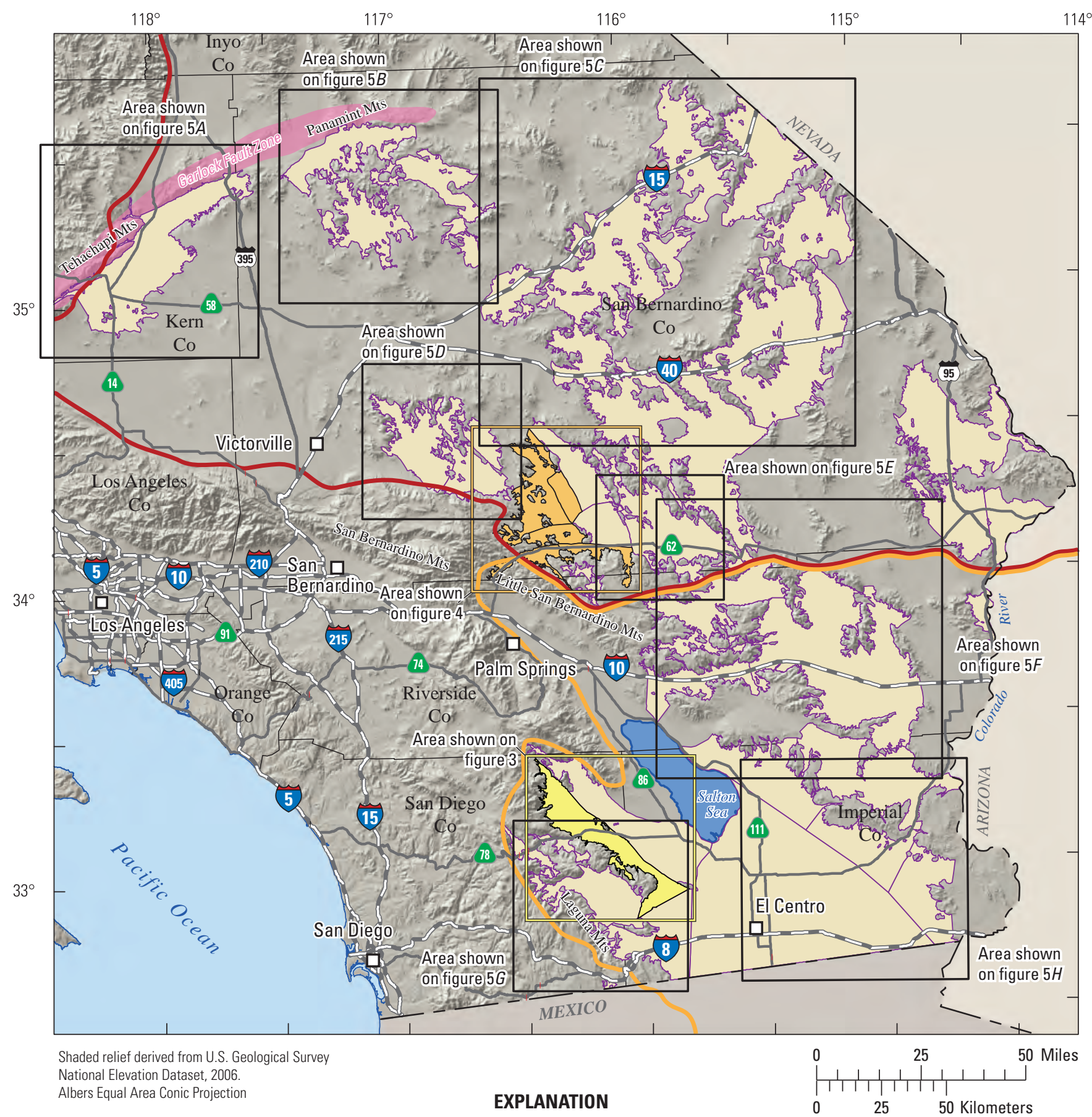

Approximate boundary of $\quad$ Approximate boundary of the Sonoran Desert the Mojave Desert

Figure 2. The location of the Borrego Valley, Central Desert, and Low-Use Basins of the Mojave and Sonoran Deserts (CLUB) Groundwater Ambient Monitoring and Assessment (GAMA) study units. 


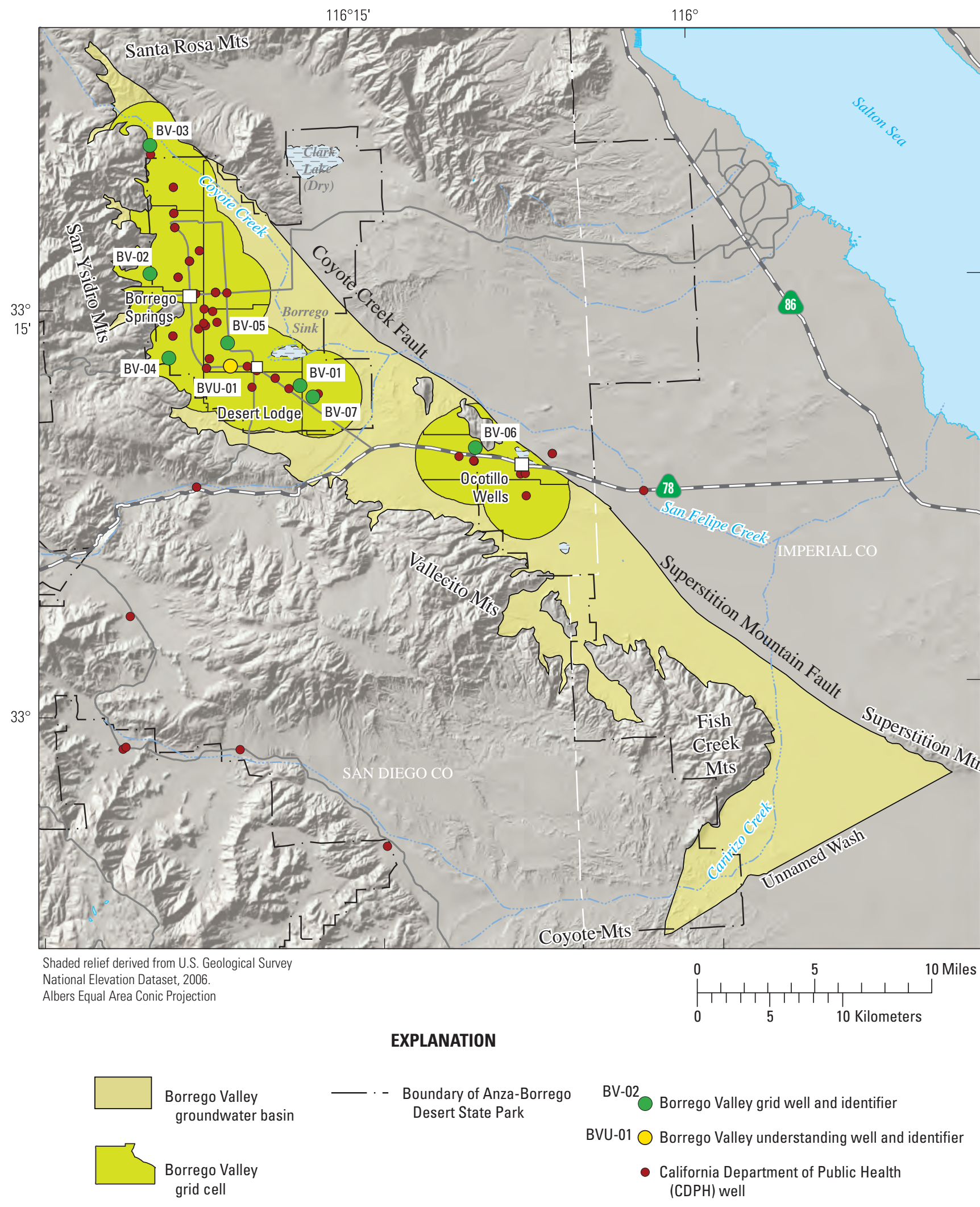

Figure 3. The Borrego Valley study area (BV), the boundaries of the California Department of Water Resources (CDWR) defined groundwater basins, the distribution of the Central Desert study area grid cells, the location of California Department of Public Health (CDPH) wells, and the location of sampled grid wells. 


\section{CLUB Study Unit-Central Desert Study Area}

The Central Desert study area (hereinafter referred to as the CD study area) is $353 \mathrm{mi}^{2}$ in area and contains six CDWR-defined basins and subbasins (California Department of Water Resources, 2003b, 2004b-f). The CD study area lies within the southern part of the M ojave Desert about 30 mi north of the city of Palm Springs and includes the northernmost section of the J oshua Tree N ational Park (fig. 4). The study area is bounded on the west by the uplands of the San B ernardino M ountains and the northern reaches of the E merson fault. It is bounded to the north by the Johnson Valley fault zone and I ron Ridge. The eastern boundary of the study area is defined by the Surprise Spring fault and the Hidalgo, Copper, and Pinto M ountains. The southernmost borders of the study area are L ower M orongo Canyon, the Little San B ernardino M ountains, and the uplands areas of the J oshua Tree National Park (California Department of Water Resources, 2003b, 2004b-f).

Land-surface altitudes in the study area range from approximately 2,300 ft above msl near Emerson L ake in the northern part of the study area, to over 5,000 ft above msl in the Little San B ernardino M ountains, located south of the town of Yucca Valley. The northern and western portions of the study area are drained by Pipes Wash to Emerson Lake. The southernmost reaches of the study area are drained by the $B$ ig and Little M orongo Creeks. Small ephemeral streams drain the eastern parts of the study area towards E merson and Deadman Lakes (California D epartment of Water Resources, 2003b, 2004b-f) (fig. 4).

The climate in the study area is classified as high arid desert (due to the land-surface altitude), with hot, dry summers and cold winters (PRISM Climate Group, Oregon State University, 2010; U.S. Department of C ommerce, National Climatic Data Center, 2010). Rainfall in the study area primarily stems from storms originating in the Pacific Ocean and is fairly evenly distributed throughout the year. Average annual precipitation in the study area is approximately $6.5 \mathrm{in}$. (PRISM Climate Group, Oregon State U niversity, 2010; Western Regional Climate Center, 2010).

The primary aquifers in the study area are located in unconsolidated to partly consolidated continental deposits and alluvium of M iocene to Q uaternary age. These unconfined water-bearing formations consist of interbedded conglomerates, gravels, sands, and silts deposited into alluvial fan systems. To a lesser extent, groundwater in the study area is found in deposits of clays, sandy-clays, distal silts, and dune sand (California Department of Water Resources, 2003b, 2004b-f).

The general direction of groundwater flow in the study area is from the southern, western, and eastern parts, towards the center, then northward to the Emerson L ake area. In the southwesternmost part of the study area, the direction of groundwater flow follows Morongo Canyon to the southwest then exits the study area by way of L ower M orongo Canyon. The east-west trending Pinto M ountain fault is the most influential hydrologic barrier to groundwater movement in the study area, with water table differences across the fault of more than $125 \mathrm{ft}$ in some locations. A dditionally, the Emerson, Surprise Spring, and M orongo Valley faults and the J ohnson Vall ey fault zone act as impediments to groundwater movement (M endez and Christensen, 1997; California Department of Water Resources, 2003b, 2004b-f; U.S. Geological Survey, 2009) (fig. 4).

$G$ roundwater recharge in the study area occurs from a mixture of ambient recharge (infiltration of runoff from surrounding mountains and hills into Little and Big M orongo Creeks, Pipes Wash, and Emerson L ake, seepage from ephemeral streams, and direct percolation of precipitation), subsurface inflow (from non-alluvial geologic units that bound the alluvial basins), and engineered recharge (percolation ponds and septic tank effluent) (California Department of Water Resources, 2003b, 2004b-f; U.S. G eological Survey, 2009) (fig. 4). 


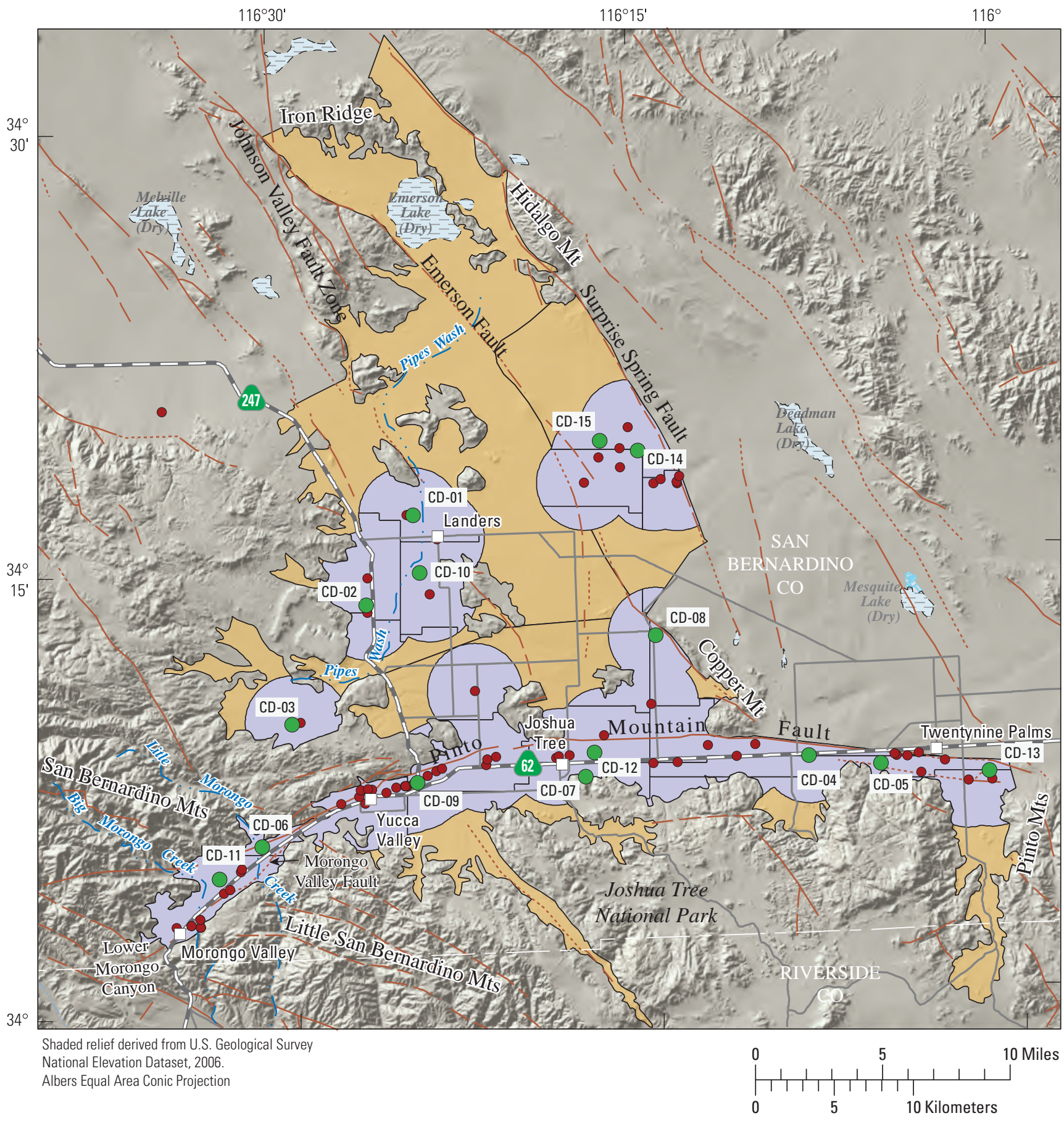

EXPLANATION

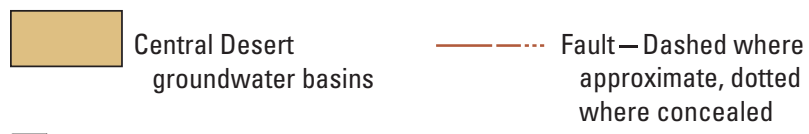
CD-02
Central Desert grid well and identifier
- California Department of Public Health (CDPH) well

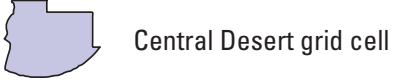

Figure 4. The Central Desert study area (CD), the boundaries of the California Department of Water Resources (CDWR) defined groundwater basins, the distribution of the CD study area grid cells, the location of California Department of Public Health (CDPH) wells, and the location of sampled grid wells. 


\section{CLUB Study Unit-Low-Use Basins of the Mojave and Sonoran Deserts Study Area}

The L ow-U se Basins of the M ojave and Sonoran Deserts study area (hereinafter referred to as the LUB study area) is $11,512 \mathrm{mi}^{2}$ in area and contains a total of 40 CDWR-defined basins and subbasins (California Department of Water Resources, 2003c, 2004g-ss). These basins and subbasins are spread over a large area in southeastern California that encompasses portions of the M ojave and Sonoran D eserts (fig. 2). The LU B study area is bounded on the west by the L aguna, San Bernardino, and Little San Bernardino $M$ ountains. The northern border of the study area is bounded by the Garlock fault zone and the Tehachapi, Chuckwalla, El Paso, Panamint, Soda, and Clark M ountains. The eastern border of the study area is bounded by the state of N evada and the Colorado River, and the southern boundary is the international border with M exico (fig. 5A-H).

\section{Low-Use Basins of the Mojave and Sonoran Deserts Study Area-Mojave Desert Region}

In the LUB study area, 24 CDWR-defined basins and subbasins are located in the M ojave Desert (hereinafter referred to as the LUB M ojave Desert region). The LUB Mojave Desert region consists of the CDWR-defined basins and subbasins located along and to the north of California State R oute 62 (fig. 2). L and-surface altitudes in the region range from approximately $600 \mathrm{ft}$ above msl near B ristol Lake, to over 7,900 ft above msl on the flanks of the Clark M ountains located northeast of the city of Baker (fig. 5C). The major surface drainage features in the region are the $L O S$ A ngeles A queduct, $M$ ojave River, and numerous ephemeral streams, creeks, and washes that flow towards dry lake beds located inside or adjacent to the groundwater basins and (or) subbasins (fig. 5A-E).

The climate in this region is classified as high arid desert (due to the land-surface altitude), with hot, dry summers and cold winters (PRISM Climate Group, Oregon State U niversity, 2010; U.S. Department of Commerce, N ational Climatic Data Center, 2010). The region lies in the rain shadow of the Tehachapi and the Sierra N evada M ountains with rainfall principally occurring in the winter months from storms originating in the Pacific Ocean. Average annual precipitation in the region is approximately 6 inches per year (in/yr). Some basins and subbasins can potentially receive no annual rainfall (PRISM Climate Group, Oregon State U niversity, 2010; Western Regional Climate Center, 2010).

A quifers in the region are found in alluvial deposits of $\mathrm{M}$ iocene to $\mathrm{H}$ olocene age. The primary aquifers in the region are located in alluvium of Q uaternary age. To a lesser extent, groundwater is found in Tertiary alluvium primarily underlying the alluvial deposits of Quaternary age, which are composed largely of unconsolidated to semi-consolidated clays, silts, sands, and gravels. Water-bearing formations in the region are on average about 2,000-ft thick (California Department of Water Resources, 2003c, 2004g-r, u-bb).

The general direction of groundwater flow in the region is from the surrounding mountains and hills towards dry lake beds located inside or adjacent to the basins and (or) subbasins. N early every basin and subbasin that makes up the region has faults present. Some faults act as hydrologic barriers, while the effect of other faults on groundwater flow is unknown (California D epartment of Water Resources, 2003C, 2004g-r, u-bb). In addition, an anticline is present north and west of the city of Twentynine Palms, limiting groundwater interaction between the LUB M ojave Desert region and the $C D$ study area (California Department of Water Resources, 2004w-y) (fig. 5C and 5E).

$G$ roundwater recharge in the region occurs from a mixture of ambient recharge (infiltration of runoff from the surrounding mountains into alluvial fan deposits, direct percolation of precipitation, and seepage from ephemeral rivers, streams, and washes) and subsurface inflow (from non-alluvial geologic units that bound the alluvial basins) (California Department of Water Resources, 2003c, 2004g-r, u-bb).

\section{Low-Use Basins of the Mojave and Sonoran Deserts Study Area-Sonoran Desert Region}

In the LUB study area, 16 CDWR-defined basins are situated in the Sonoran Desert (hereinafter referred to as the LUB Sonoran Desert region). The LU B Sonoran Desert region is composed of CDWR-defined basins located to the south of California State R oute 62 (fig. 2). L and-surface altitudes in this region range from approximately $230 \mathrm{ft}$ below msl in the basins surrounding the Salton Sea, to approximately $9,700 \mathrm{ft}$ above msl in the Santa Rosa M ountains just north of the BV study area (figs. 3 and $5 \mathrm{~F}-\mathrm{H}$ ). The major surface drainage features of the region are the Salton Sea and the Colorado River. The Salton Sea is fed by the $\mathrm{N}$ ew and A lamo Rivers, San Felipe, Vallecitos, and C aririzo Creeks, and unnamed ephemeral streams. The Colorado River supplies water to the Colorado A queduct, the A II A merican, Coachella, and East $\mathrm{Highline} \mathrm{Canals}$, and the $\mathrm{New}$ and A lamo Rivers (fig. $5 \mathrm{~F}-\mathrm{H}$ ).

The climate in the region is classified as subtropical desert (due to the land-surface altitude), with very hot summers and cool winters (PRISM Climate Group, Oregon State U niversity, 2010; U.S. Department of Commerce, National Climatic Data Center, 2010). Rainfall in these basins follows a bimodal pattern similar to that of the BV study area. The winter storms originating in the Pacific Ocean have a greater influence on precipitation in the western parts of the LUB Sonoran Desert region, and the N orth A merican $M$ onsoon accounts for most of the rainfall in the central and eastern parts (A dams, 1997). A nnual rainfall in the region is approximately $4 \mathrm{in} / \mathrm{yr}$, while some basins can receive little to no precipitation per year (PRISM Climate Group, Oregon State U niversity, 2010; Western R egional Climate Center, 2010). 


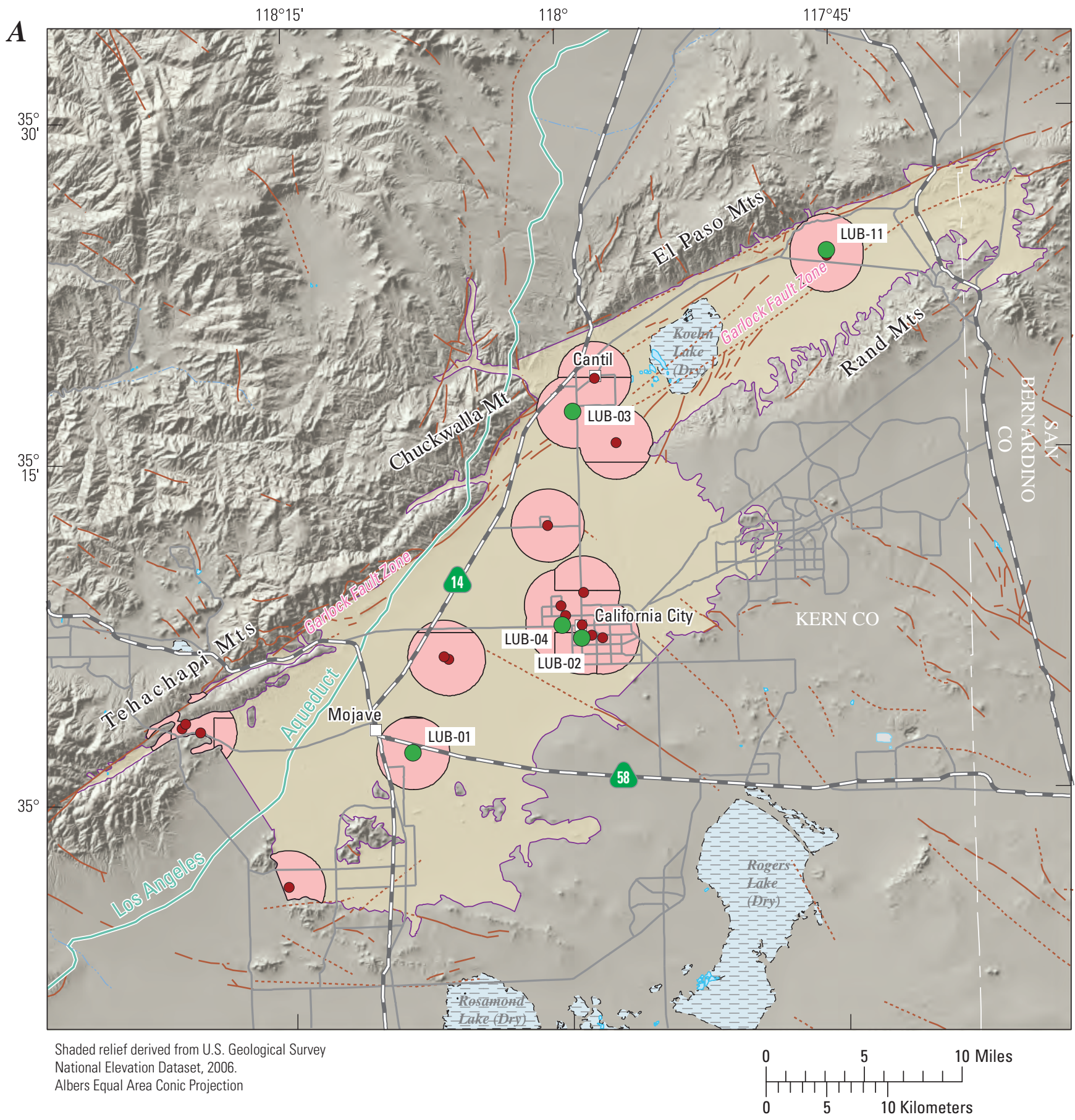

EXPLANATION

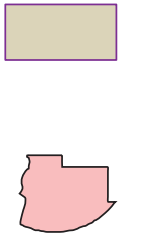

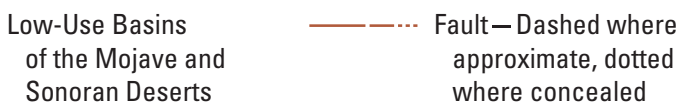

groundwater basin

Low-Use Basins

of the Mojave and

Sonoran Deserts grid cell
LUB-02

Low-Use Basins of the Mojave and Sonoran Deserts grid well and identifier

- California Department of Public Health (CDPH) well

Figure 5. $(A)$ The northwestern part, $(B)$ the northern part, $(C)$ the northeastern part, $(D)$ the western part, $(E)$ the central part, $(F)$ the eastern part, $(G)$ the southwestern part, and $(H)$ the southeastern part of the Low-Use Basins of the Mojave and Sonoran Deserts study area (LUB), the boundaries of the California Department of Water Resources (CDWR) defined groundwater basins, the distribution of the LUB study-area grid cells, the location of California Department of Public Health (CDPH) wells, and the location of sampled grid and understanding wells. 


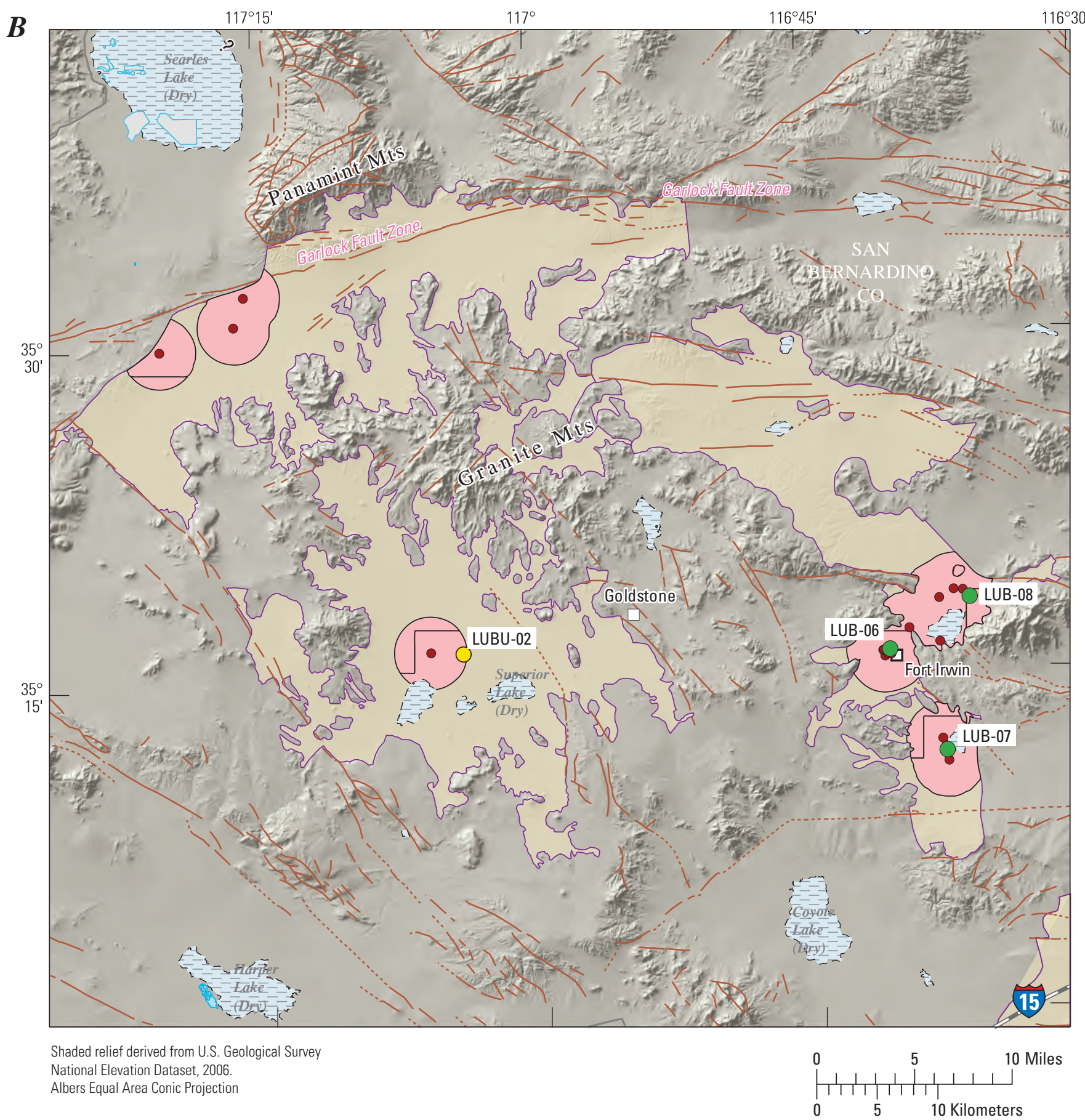

EXPLANATION

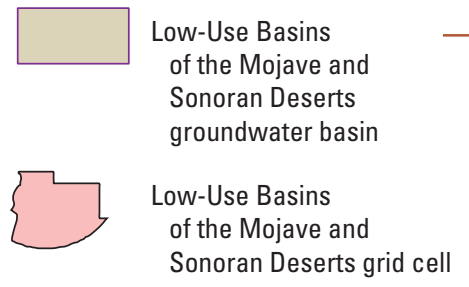
Fault-Dashed where
approximate, dotted
where concealed

Sonoran Deserts grid cell

\author{
LUB-07 \\ Low-Use Basins of the Mojave and \\ Sonoran Deserts grid well and identifier \\ LUBU-02 Low-Use Basins of the Mojave and \\ Sonoran Deserts understanding well and identifier \\ - California Department of Public Health \\ (CDPH) well
}

Figure 5.-Continued 
C

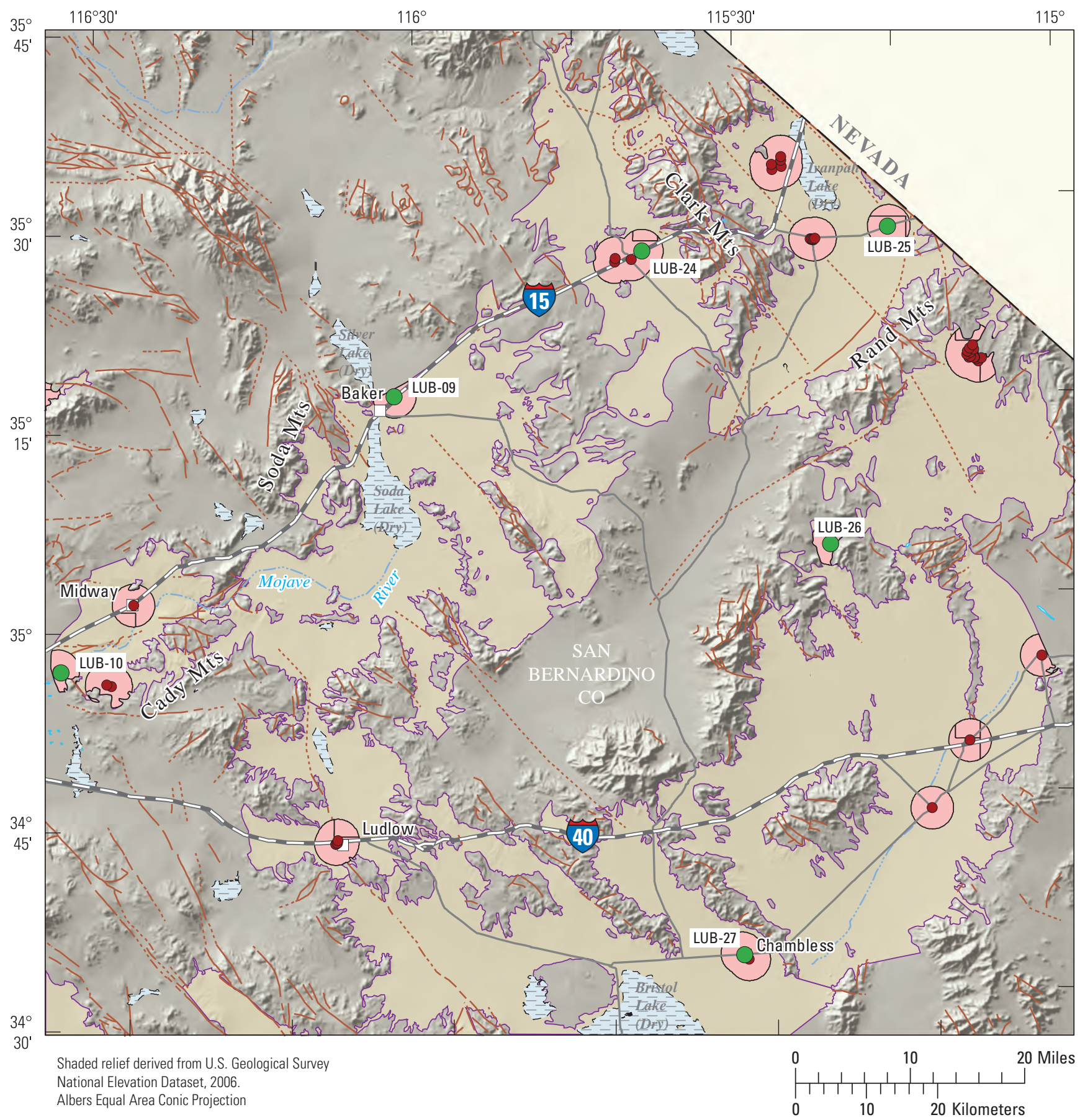

EXPLANATION

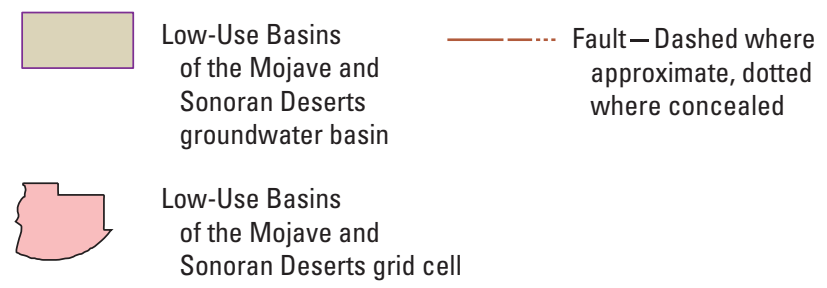

LUB-24

Low-Use Basins of the Mojave and
Sonoran Deserts grid well

- California Department of Public Health (CDPH) well

Figure 5.-Continued 
D

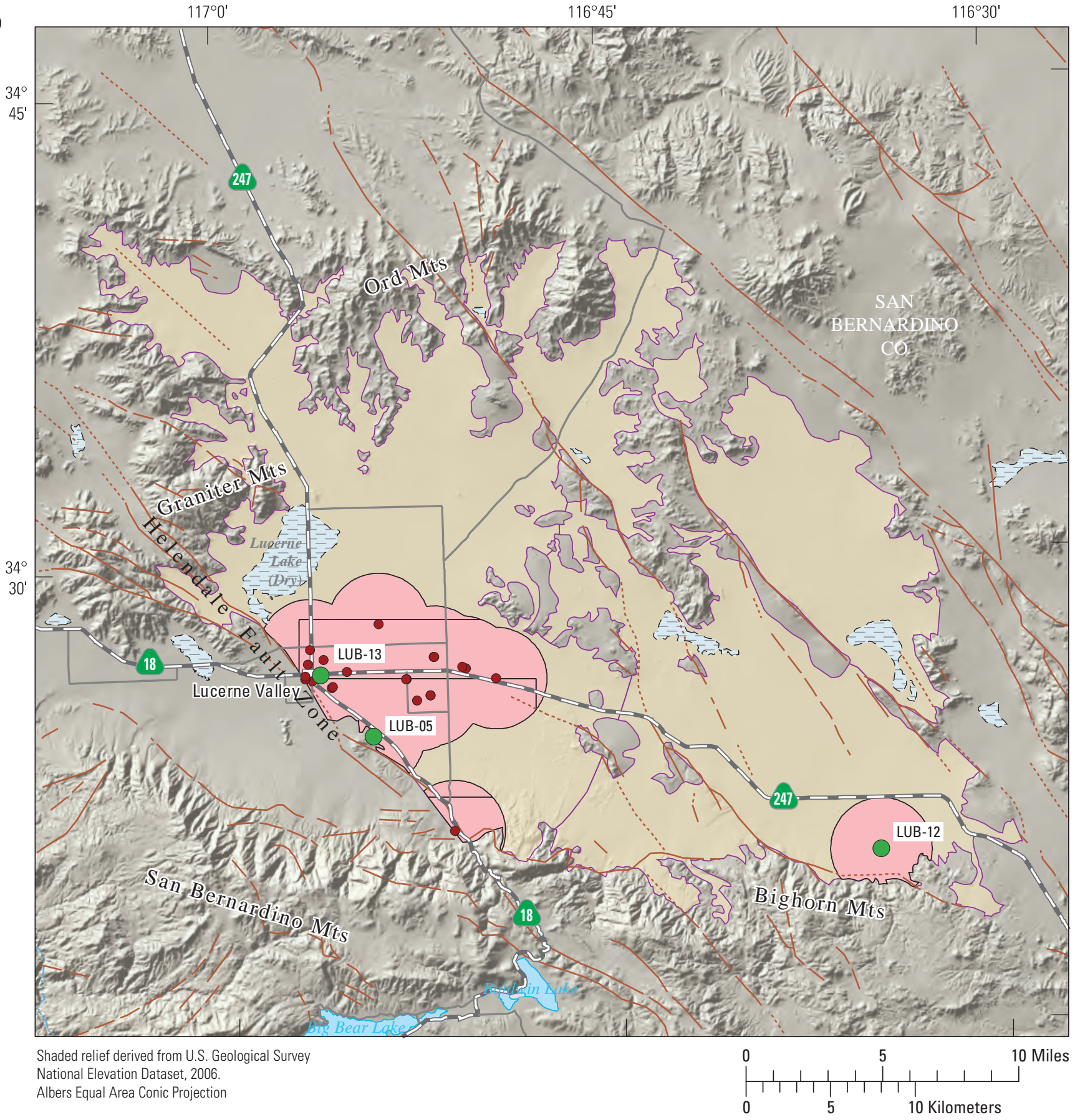

EXPLANATION

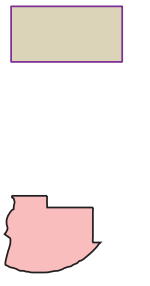

Low-Use Basins of the Mojave and Sonoran Deserts groundwater basin

Low-Use Basins

of the Mojave and

Sonoran Deserts grid cell
LUB-05 approximate, dotted where concealed
Low-Use Basins of the Mojave and Sonoran Deserts grid well and identifier

- California Department of Public Health (CDPH) well

Figure 5.-Continued 


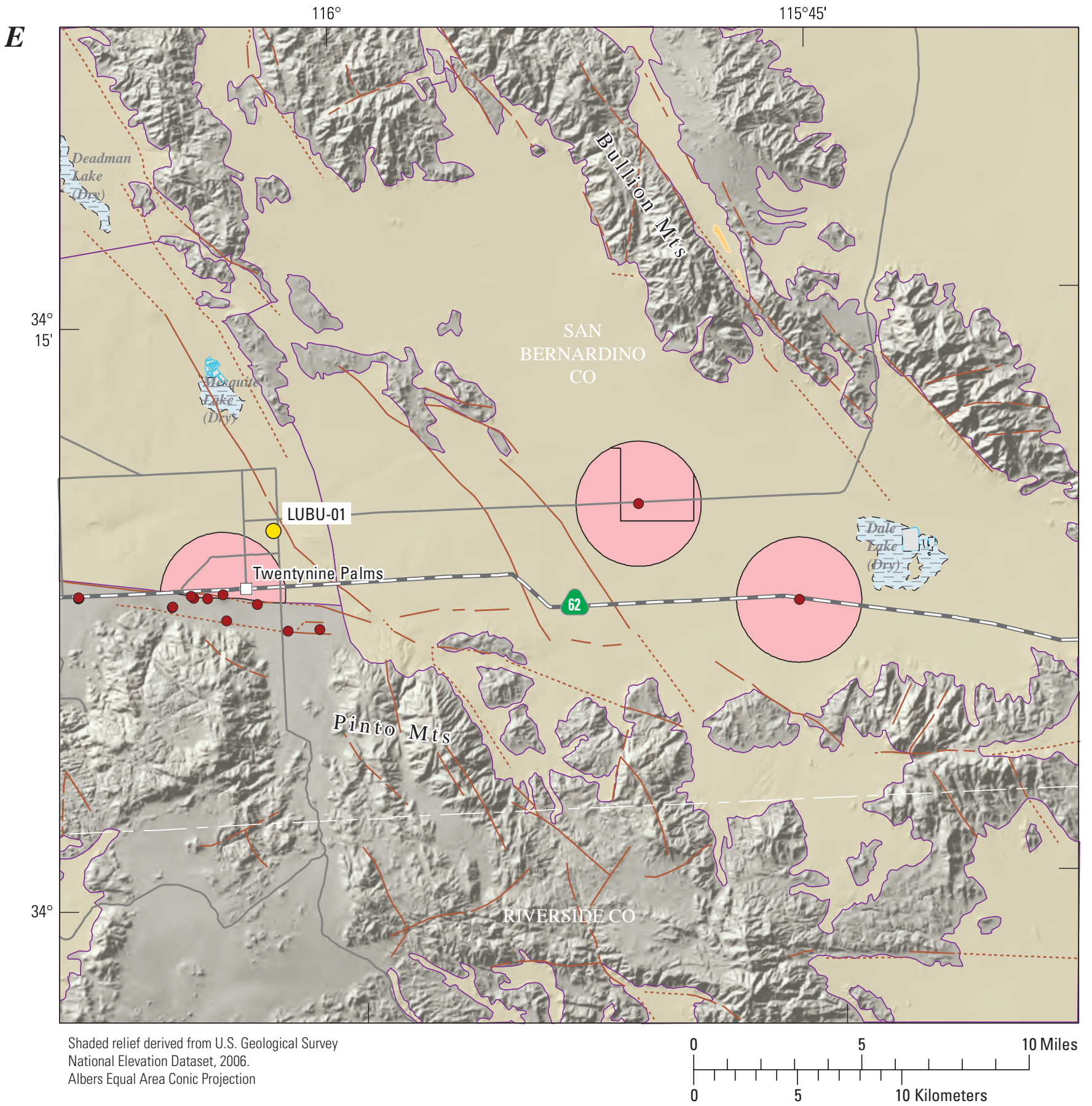

EXPLANATION

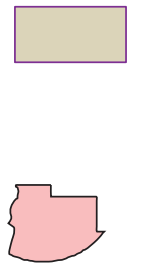

Low-Use Basins of the Mojave and Sonoran Deserts groundwater basin

Fault-Dashed where approximate, dotted where concealed

LUBU-01 Low-Use Basins of the Mojave and Sonoran Deserts understanding well and identifier

- California Department of Public Health (CDPH) well

\section{Low-Use Basins}

of the Mojave and

Sonoran Deserts grid cell

Figure 5.-Continued 


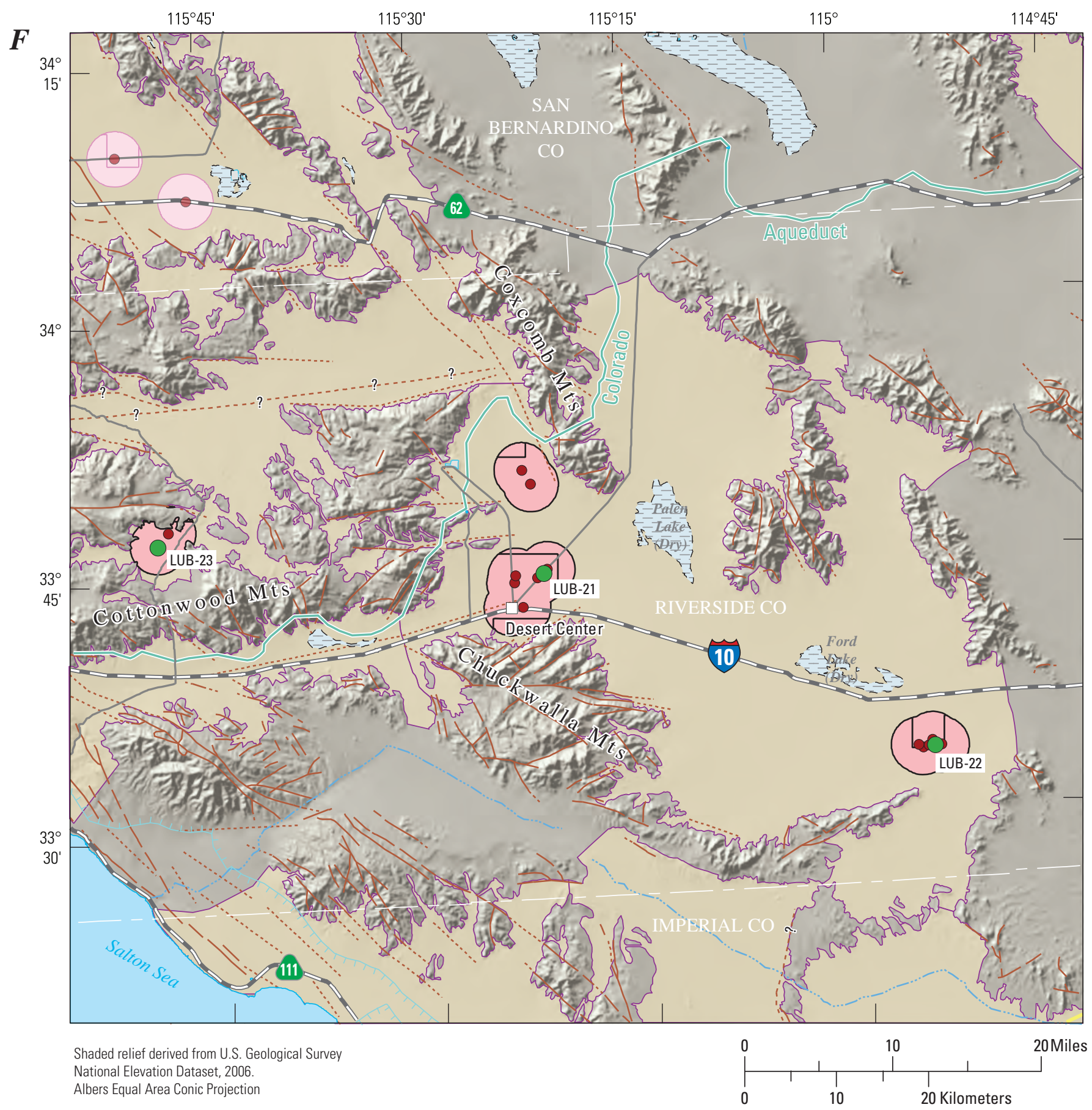

EXPLANATION
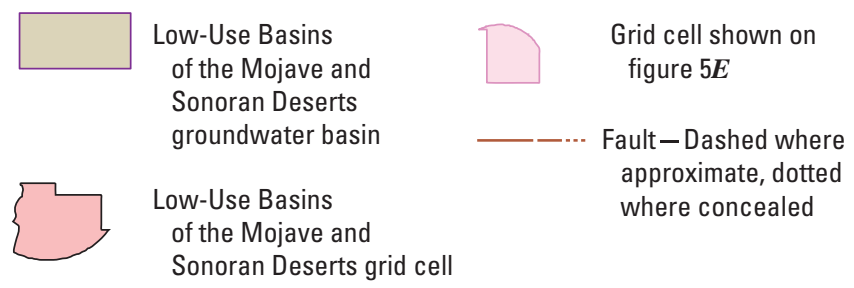

LUB-21

Low-Use Basins of the Mojave and Sonoran Deserts grid well and identifier

- California Department of Public Health (CDPH) well

Figure 5.-Continued 


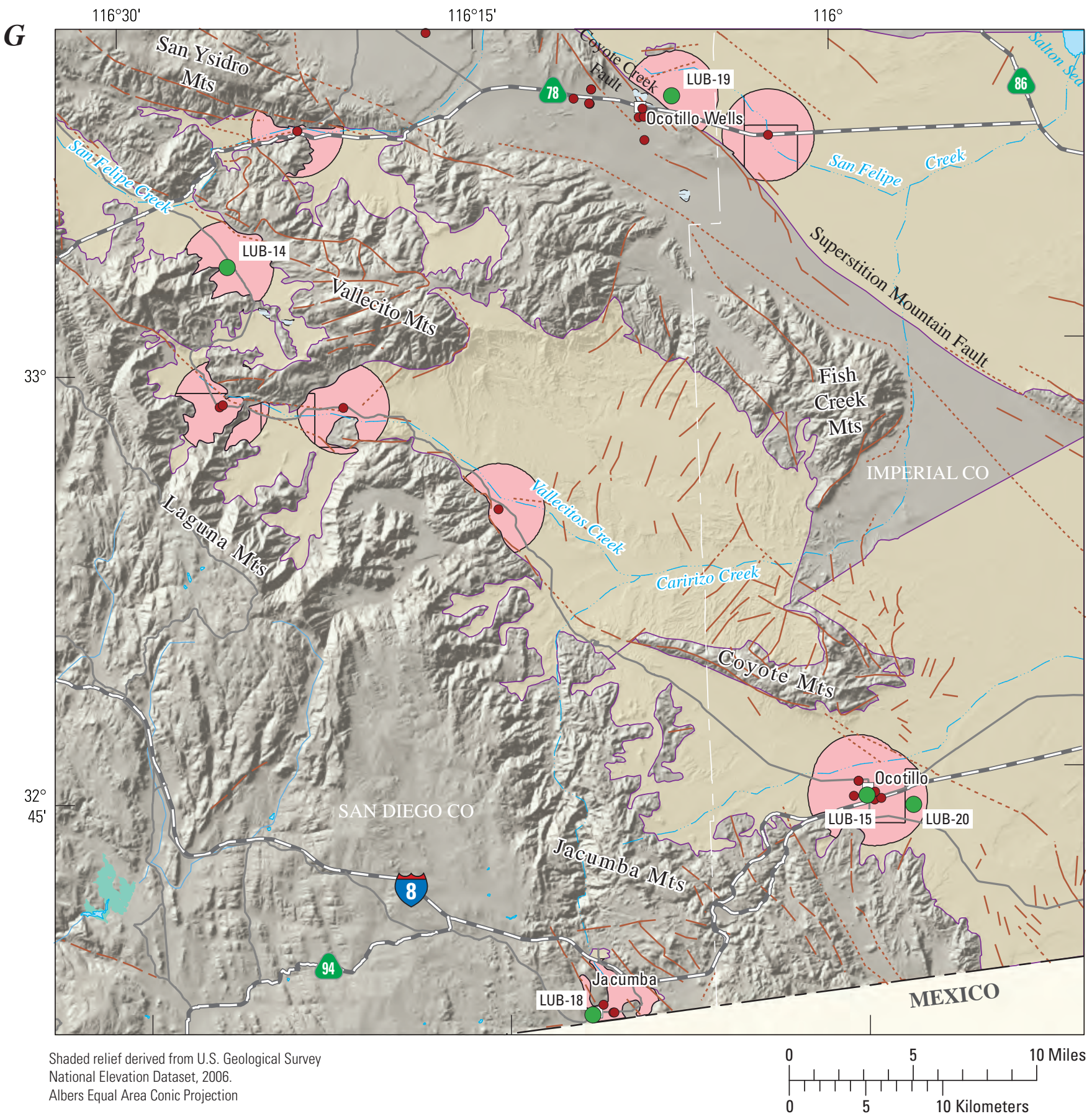

EXPLANATION
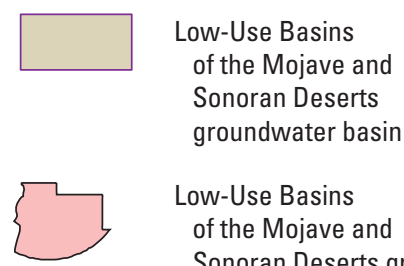

Low-Use Basins

of the Mojave and

Sonoran Deserts grid cell
LUB-15

uult-Dashed whe approximate, dotted where concealed
Low-Use Basins of the Mojave and Sonoran Deserts grid well and identifier

- California Department of Public Health (CDPH) well

Figure 5.-Continued 


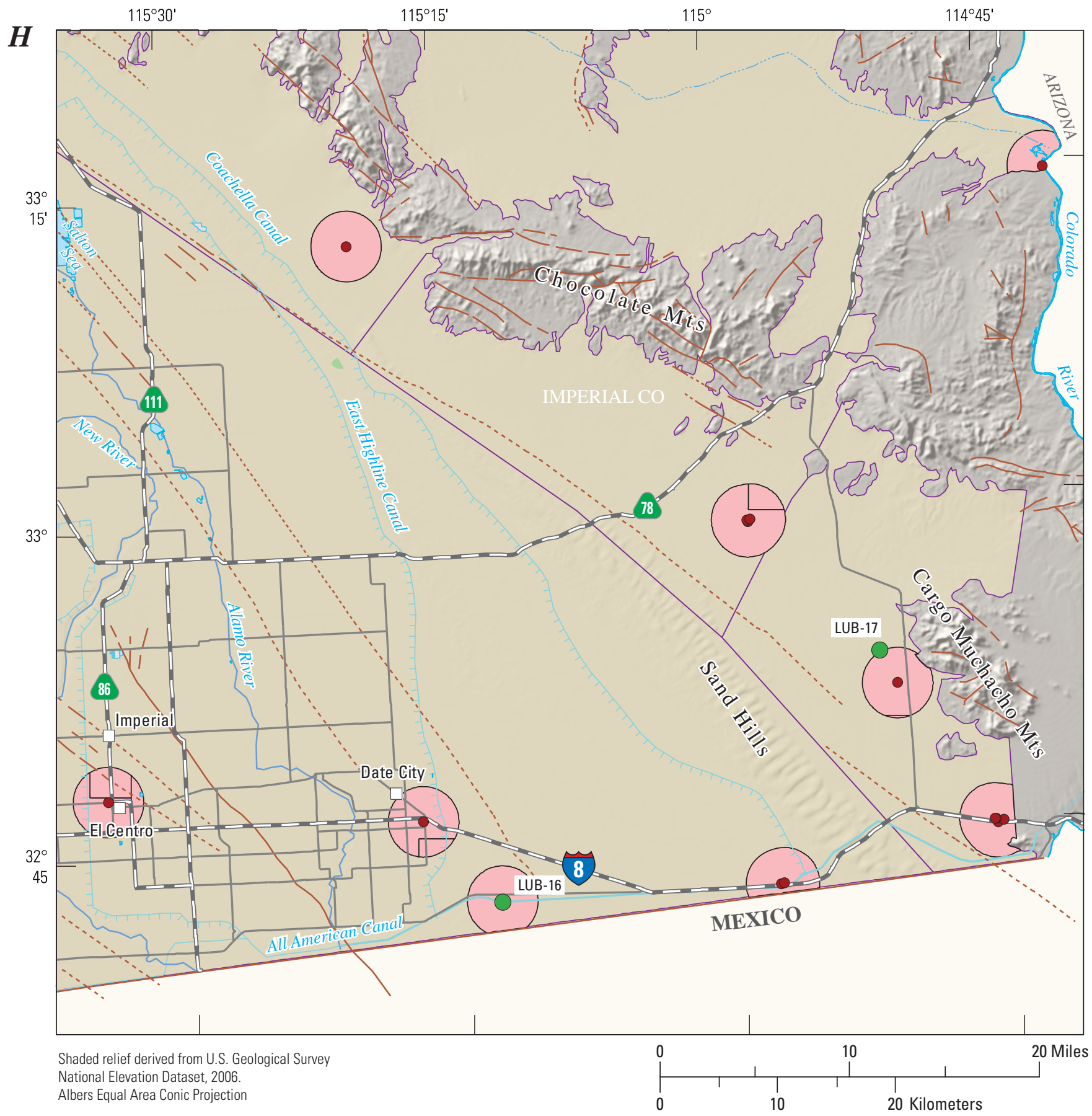

EXPLANATION

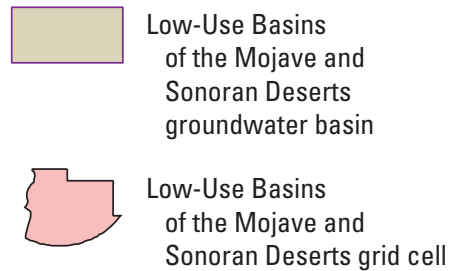

Fault-Dashed where approximate, dotted where concealed

LUB-16

Low-Use Basins of the Mojave and Sonoran Deserts grid well and identifier

- California Department of Public Health (CDPH) well

Figure 5.-Continued 
The primary aquifers in the region are located in alluvium of Quaternary age. To a lesser extent, groundwater is found in Tertiary-aged alluvium that is usually overlain by the alluvium of Q uaternary age. B oth the Quaternary and Tertiary deposits are composed of unconsolidated to semi-consolidated gravels, sands, silts, and clays. Water-bearing formations in the study area are, on average, $850 \mathrm{ft}$ thick (California Department of Water Resources 2004s, t, cc-ss).

The general direction of groundwater flow in most of the basins that make up the LUB Sonoran Desert region is towards rivers, creeks, and streams that eventually discharge into the Salton Sea. In the remaining basins, the direction of groundwater flow is from the surrounding hills and mountains towards dry lake beds. The region has numerous faults associated with the San A ndreas fault zone that act as the major barriers to groundwater flow. To a lesser extent, clay deposits and bedrock act as impediments to groundwater movement (California Department of Water Resources, 2004s, t, cC-ss).

$G$ roundwater recharge in the region occurs from a variety of sources: ambient recharge (infiltration of run off from the surrounding mountains into alluvial fan deposits, direct percolation of precipitation, seepage from ephemeral rivers, streams, and washes, agricultural return, and leaching along canals) and subsurface inflow (from non-alluvial geologic units that bound the alluvial basins) (California Department of Water Resources 2004s, t, cc-ss).

\section{Methods}

M ethods used for the GA M A-PB P were selected to achieve the following objectives: (1) design a sampling plan for suitable statistical representation; (2) collect samples in a consistent manner; (3) analyze samples by using proven and reliable laboratory methods; (4) assure the quality of the groundwater data; and (5) maintain data securely and with relevant documentation. The appendix contains detailed descriptions of the sample-collection protocols and analytical methods, the QA plan, and the results of analyses of QC samples.

\section{Study Design}

The wells selected for sampling in this study reflect the combination of two well-selection strategies. Fortynine wells were selected to provide a statistically unbiased, spatially distributed assessment of the quality of groundwater resources used for public drinking-water supply. Wells sampled as part of the spatially distributed, randomized grid-cell network, hereinafter, are referred to as "grid wells." Three additional, non-randomized wells (hereinafter referred to as "understanding wells") were sampled in the BV and LUB study areas to aid in the understanding of groundwater-quality issues.
The spatially distributed wells were selected by using a randomized grid-based method (Scott, 1990). The randomized grid-based method divides the study areas into equal-area grid cells; however, geographic features may force a grid cell to be divided into multiple pieces to obtain the designated coverage area for each cell. For instance, a portion of a grid cell may be located on either side of a mountain range, but the grid cell is still considered one grid cell.

In the CLUB study unit, the approach was to sample one available CDPH well located within each grid cell. If a grid cell contained more than one CDPH well, each well randomly was assigned a rank. The highest ranking well that met basic sampling criteria (for example, sampling point located prior to treatment, or capability to pump for several hours) was sampled. If a grid cell contained no accessible CDPH wells, then other types of wells, such as domestic, irrigation, and (or) industrial, were considered for sampling. These "alternative" wells were identified from wells listed in USGS databases or by door-to-door canvassing. Wells with depths and screened intervals similar to those in CDPH wells in the area were selected. In this fashion, one well was selected for possible sampling in each cell to provide a spatially distributed, randomized monitoring network.

The BV study area was divided into nine equal-area grid cells, each approximately $9.7 \mathrm{mi}^{2}$ ( 25 square kilometers [ $\left.\mathrm{km}^{2}\right]$ ) in area; wells in seven of the nine grid cells were sampled (fig. 3). The CD study area was divided into 17 equal-area grid cells, approximately $9.2 \mathrm{mi}^{2}\left(24 \mathrm{~km}^{2}\right)$ in area; wells in 15 of the 17 grid cells were sampled (fig. 4). The LUB study area was divided into 30 equal-area grid cells, approximately $20 \mathrm{mi}^{2}\left(52 \mathrm{~km}^{2}\right)$ in area; wells in 27 of the 30 grid cells were sampled (fig. 5A-H).

The design of the grid cells differed within the CLUB study unit because of differences in the distribution of CDPH wells and the overall size of each study area. A direct sampling approach involving use of circular buffers around each $C D P H$ well was used, as has been used in other GA M A-PBP study units with few and (or) unevenly distributed CDPH wells (W right and others, 2005; K ulongoski and others, 2006; Fram and B elitz, 2007; Ferrari and others, 2008; L and and B elitz, 2008; Densmore and others, 2009; Fram and others, 2009; B ennett and others, 2009; M athany and B elitz, 2009; Schmitt and others, 2009; Goldrath and others, 2010; M athany and others, 2010). These buffers have a radius of about 3 kilometers $(\mathrm{km})$, and the combined area was divided into the equal-area grid cells. In the BV and CD study areas, the CDPH wells were clustered in and around population centers, and the two study areas were relatively similar in size (BV $=238 \mathrm{mi}^{2}$ and $\left.C D=353 \mathrm{mi}^{2}\right)$; therefore, the size of the grid cells were similar (figs. 3 and 4). In the LUB study area, the CDPH wells were distributed sporadically, and the study area was much larger than the other study areas (LUB $=11,512 \mathrm{mi}^{2}$ ); consequently, the size of each grid cell was much larger than the grid cells in other study areas (fig. 5A-H). 
The 49 grid wells sampled in the CLUB study unit were numbered in the order in which samples were collected in each study area with the prefix varying by study area; "BV" for the B orrego Valley, "CD" for the Central Desert, and "LUB" for the L ow-U se B asins of the M ojave and Sonoran D eserts (figs. 3 , 4, and $\underline{5 \mathrm{~A}-\mathrm{H} \text { ). }}$.

The three understanding wells sampled as part of the study were not included in the statistical characterization of water quality in the CLUB study unit because inclusion of these wells would lead to the overrepresentation of some cells. These additional wells were numbered in the order of sample collection with the prefix modified from those used by the grid cells: "BVU" or "LUBU" ("U" indicates "understanding") (figs. $3, \underline{5 B}$ and $\underline{5 E}$ ).

The GAMA alphanumeric identification number for each well, along with the date sampled, sampling schedule, land-surface altitude, well type, and available wellconstruction information, is shown in table 1. Groundwater samples were collected from $42 \mathrm{CDPH}$ wells, 4 domestic wells, 2 irrigation wells, 2 unused wells, 1 industrial well, and 1 institutional well during the period from December 2008 to M arch 2010.

Well locations were verified by using a global positioning system (GPS), 1:24,000-scale USGS topographic maps, comparison with existing well information in USGS and CDPH databases, and information provided by well owners, drillers' logs, and (or) other sources of construction information. Well location and information were recorded by hand on field sheets and electronically on field laptop computers using the A Iternate Place Entry Form (APE) program designed by the USGS. All information was verified and then uploaded into the USGS National Water Information System (NWIS) database. Well location, well owner, and well-use information is confidential.

The wells in the CLUB study unit were sampled by using a tiered analytical approach. All wells were sampled for a standard set of constituents: water-quality indicators, VOCs, pesticides and pesticide degradates, perchlorate, stable isotopes of hydrogen and oxygen in water, stable isotopes of carbon in dissolved inorganic carbon and carbon-14 abundance, tritium, and dissolved noble gases. The standard set of constituents was termed the "fast" schedule (table 2). Wells on the "slow" schedule were sampled for all constituents on the fast schedule, plus pharmaceutical compounds, $\mathrm{N}$-nitrosodimethylamine (NDM A), trace elements, nutrients, major and minor ions, silica, total dissolved solids (TDS), stable isotopes of boron and strontium in water, radon-222, radium isotopes, and gross alpha and gross beta radioactivity. Species of inorganic chromium were sampled for on the CL UB study-unit slow sampling schedule in December 2008. Hexaval ent chromium (chromium-VI, Cr-VI) analysis from a second laboratory was added to the CLUB study-unit slow sampling schedule starting in October 2009. A dditionally, the 18 wells on the fast schedule in the LUB study area were sampled for trace elements, nutrients, major and minor ions, silica, and TDS (table 2).
F ast and slow refers to the relative time required to sample the well for all analytes on the schedule. Two slow or three fast wells generally could be sampled in 1 day. In the CLUB study unit, 28 of the wells were sampled on the fast schedule ( 26 grid and 2 understanding), and 24 wells were sampled on the slow schedule ( 23 grid and 1 understanding) (table 1).

\section{Sample Collection and Analysis}

Samples were collected with modified USGS National Water-Quality A ssessment (NAW QA) Program (K oterba and others, 1995) and USGS National Field M anual (NFM) (U.S. Geological Survey, variously dated) sampling protocols. These sampling protocols were followed so that representative samples of groundwater were collected at each site, and so that the samples were collected and handled in ways that minimized the potential for contamination.

Table 3A-K lists the compounds analyzed in each constituent class. Groundwater samples were analyzed for $85 \mathrm{VOCs}$ (table 3A); 63 pesticides and pesticide degradates (table 3B); 13 pharmaceutical compounds (table 3C); 2 constituents of special interest (table 3D); 24 trace el ements (table 3E); 5 nutrients (table 3F); 9 major and minor ions, silica, TDS, and alkalinity (table 3G); species of inorganic chromium (table $\underline{3 \mathrm{H}}$ and $\underline{3 \mathrm{I}}$ ); 4 stable isotopes and 7 radioactive constituents, including tritium and carbon- 14 abundance (table 3)); and 6 dissolved noble gases and helium isotope ratios (table 3K). The methods used for sample collection and analysis are described in the appendix section titled "Sample Collection and A nalysis."

\section{Data Reporting}

The methods and conventions used for reporting the data are described in the appendix section titled "Data Reporting." Three water-quality indicators - alkalinity, $\mathrm{pH}$, and specific conductance-were measured in the field and at the USGS National Water Quality Laboratory (NW QL), and both results are reported (see the appendix section titled "Constituents on M ultiple A nalytical Schedules"). Total chromium and Cr-V I were measured by two different laboratories, and all results are reported (tables $8, \underline{11}$, and $\underline{12}$ ). Tritium activities were measured by two different laboratories, but only one set of results were available at the time this report was published.

\section{Quality-Assurance Methods}

The QA/QC procedures used for this study followed the protocols used by the NAW QA Program (K oterba and others, 1995) and described in the NFM (U.S. Geological Survey, variously dated). The QA plan followed by the USGS NWQL, the primary laboratory used to analyze samples for this study, is described in Pirkey and Glodt (1998) and M aloney (2005). 
QC samples collected in the CLUB study unit are blanks, replicates, and matrix and surrogate spikes. QC samples were collected to evaluate potential contamination, as well as bias and variability of the data that may have resulted from sample collection, processing, storage, transportation, and laboratory analysis. QA/QC procedures and results are described in the appendix section titled "Q uality-A ssurance M ethods."

\section{Water-Quality Results}

\section{Quality-Control Results}

Results of QC analyses (blanks, replicates, and matrix and surrogate spikes) were used to eval uate the quality of the data for the groundwater samples. On the basis of detections in NW Q L blanks and QC samples collected for this and previous GA M A - PBP study units, the reporting levels for $10 \mathrm{VOCS}$ and 13 trace el ements were raised. Detections of the $10 \mathrm{~V} O \mathrm{Cs}$ with concentrations less than the raised reporting limits were removed from the set of groundwater-quality data presented in this report. Detections of the 13 trace el ements with concentrations less than the raised reporting limits are flagged with a less than or equal to symbol $(\leq)$ in this report (see table A 3 and additional discussion in the appendix section titled "Detections in Field B lanks and A pplication of SRLs"). Results from the replicates confirm that the procedures used to collect and analyze the samples were consistent. Variability for nearly 100 percent of the replicate pairs for constituents detected in samples was within the acceptable limits (table A 4A-C). M edian matrix-spike recoveries for 25 of the 150 organic and special-interest constituents analyzed were outside the acceptable range of between 70 and 130 percent (tables 3B and A 5B). Constituents for which low recoveries occurred might not have been detected in some samples if they were present at concentrations near the laboratory reporting levels (LRLs), and constituents with high recoveries may indicate that reported values could be greater than what is in the sample. The $Q C$ results are described in the appendix section titled "Quality-Control Results."

\section{Comparison Benchmarks}

Concentrations of constituents detected in groundwater samples were compared with CDPH and USEPA regulatory and non-regulatory drinking-water heal th-based benchmarks and benchmarks established for aesthetic purposes (California Department of Public Health, 2008a,b; U.S. Environmental Protection A gency, 2008a-c). The chemical data presented in this report are meant to characterize the quality of the untreated groundwater within the primary aquifers of the CLUB study unit and are not intended to represent the treated drinking water delivered to consumers by water purveyors.
The chemical composition of treated drinking water may differ from untreated groundwater because treated drinking water may be subjected to disinfection, filtration, mixing with other waters, and (or) exposure to the atmosphere prior to its delivery to consumers. Comparisons of untreated groundwater to benchmarks are for illustrative purposes only and are not indicative of compliance or non-compliance with drinking-water regulations. The following benchmarks were used for comparisons:

- MCL-M aximum Contaminant L evel. Legally enforceable standards that apply to public-water systems and are designed to protect public health by limiting the levels of contaminants in drinking water. M CL s established by the USEPA are the minimum standards with which States are required to comply, and individual States may choose to set more stringent standards. CDPH has established M CL s for additional constituents not regulated by the USEPA, as well as lowered the benchmark concentration for a number of constituents with M CL s established by the USEPA. In this report, a benchmark set by the USEPA and adopted by CDPH is labeled "M CL-US," and one set by $\mathrm{CDPH}$ that is more stringent than the M CL-US is labeled "MCL-CA." Well owners are notified when constituents are detected at concentrations greater than an M CL-US or an M CL-CA benchmark in samples collected for the GAM A-PBP, but these detections do not constitute violations of $C D P H$ regulations.

- AL - Action L evel. L egally enforceable standards that apply to public-water systems and are designed to protect public health by limiting the levels of copper and lead in drinking water. Detections of copper or lead greater than the action-level benchmarks trigger requirements for mandatory water treatment to reduce the corrosiveness of water to water pipes. The action levels established by the USEPA and CDPH are the same; thus, the benchmarks are labeled "AL-US" in this report.

- SM C L-Secondary M aximum C ontaminant L evel. N on-enforceable standards applied to constituents that affect the aesthetic qualities of drinking water, such as taste, odor, and color, or the technical qualities of drinking water, such as scaling and staining. $B$ oth the USEPA and CDPH define SMCLs, but unlike MCLs, SM CL s established by CDPH are not required to be at least as stringent as those established by USEPA. SM CLs established by CDPH are used in this report (SM CL-CA) for all constituents that have SM CL-CA values. The SM CL-US is used for $\mathrm{pH}$ because no SMCL-CA has been defined. 
- NL-Notification Level. Health-based notification levels established by CDPH for some of the constituents in drinking water that lack MCLs (NL-CA). If a constituent is detected at concentrations greater than its N L-CA, California State law requires timely notification of local governing bodies and recommends consumer notification.

- HAL - L ifetime Health Advisory L evel. The maximum concentration of a constituent at which its presence in drinking water is not expected to cause any adverse carcinogenic effects for a lifetime of exposure. HAL $S$ are established by the USEPA (HAL-US) and are calculated assuming consumption of 2 liters ( $L$ ) (2.1 quarts) of water per day over a 70-year lifetime by a 70-kilogram (154-pound) adult and that 20 percent of a person's exposure comes from drinking water.

- RSD5-Risk-Specific Dose. The concentration of a constituent in drinking water corresponding to an excess estimated lifetime cancer risk of 1 in 100,000. RSD5 is an acronym for risk-specific dose at $10^{-5}$. RSD 5s are calculated by dividing the $10^{-4}$ cancer risk concentration established by the USEPA by 10 (RSD5-US).

For constituents with $\mathrm{MCLs}$, detections in groundwater samples were compared to the M CL -US or M CL-CA. Constituents with SM CLs were compared with the SM CL-CA . For chloride, sulfate, specific conductance, and TDS, CDPH defines a "recommended" and an "upper" SMCL-CA; detections of these constituents in groundwater samples were compared with both levels. The SM CL-US for these constituents corresponds to the recommended SM CL-CA. Detected concentrations of constituents without an $M C L$ or SM CL were compared to the NL-CA. For constituents without an $M C L, S M C L$, or NL-CA, detected concentrations were compared with the HAL-US. For constituents without an $M C L$, SM CL, NL-CA, or HAL-US, detected concentrations were compared with the RSD5-US. For constituents without an M CL, SM CL, NL-CA, HAL-US, or RSD 5-US, detected concentrations were compared with the A L -US. N ote that using this hierarchy to select the comparison benchmark for a constituent with more than one type of established benchmark will not necessarily result in selection of the benchmark with the lowest concentration. For example, for zinc the SM CL-CA is $5,000 \mu \mathrm{g} / \mathrm{L}$ and the HAL-US is $2,000 \mu \mathrm{g} / \mathrm{L}$, but the comparison benchmark selected by this hierarchy is the SM CL-CA. The comparison benchmarks used in this report are listed in table 3A-K for all constituents and in tables 4-14 for constituents detected in groundwater samples from the CL UB study unit. Established benchmarks are not available for all constituents analyzed for this study. Detections of constituents at concentrations greater than the selected comparison benchmark are marked with asterisks in tables 4 , 8-10, and $\underline{14 C}$.

\section{Groundwater-Quality Data}

Results from analyses of untreated-groundwater samples from the CLUB study unit are presented in tables 4-14. These results are separated into the three study areas that make up the CLUB study unit (BV, CD, and LUB). Groundwater samples collected in the CLUB study unit were analyzed for 221 constituents; 134 of those constituents were not detected in any of the samples, and 68 constituents were detected (table $3 A-K$ ). The LLNL results for dissolved noble gases, tritium, and helium isotope ratios have not been received yet and are not presented in this report; they will be included in a subsequent publication.

For organic and special-interest constituent classes that were analyzed at all of the grid wells, the results tables include the following summary statistics: the number of wells at which each analyte was detected, the frequency at which it was detected (in relation to the number of grid wells in the study unit and in each study area), and the total number of constituents detected at each well. For the inorganic, isotopic, and radioactive constituent classes, the tables include all of the wells, constituents, and samples analyzed.

Water-quality indicators measured in the field and at the NW QL are included in table 4. The results of groundwater analyses organized by compound classes are presented in tables 5-14:

- Organic constituents

- Volatile organic compounds (table 5)

- Pesticides and pesticide degradates (table 6)

- Perchlorate (table 7)

- Inorganic constituents

- Trace el ements (table 8)

- Nutrients (table 9)

- M ajor and minor ions, silica, and total dissolved solids (table 10)

- Species of inorganic chromium (table 11)

- Hexavalent chromium (chromium-VI) (table 12)

- Isotopic tracers (table 13)

- Radioactive constituents

- Radon-222 (table 14A)

- Radium isotopes (table 14B)

- Gross alpha and gross beta radioactivity (table 14C) 


\section{Water-Quality Indicators}

Field measurements of dissolved oxygen and water temperature and field and laboratory measurements of $\mathrm{pH}$, specific conductance, and alkalinity are presented in table 4. Bicarbonate and carbonate concentrations are calculated from the $\mathrm{pH}$ and alkalinity results. Dissolved oxygen, alkalinity, and bicarbonate and carbonate concentrations are used as indicators of natural processes that affect water chemistry. The $\mathrm{pH}$ value indicates the acidity of the water. Specific conductance is the measure of electrical conductivity of the water and is proportional to the amount of total dissolved solids in the water.

Field $\mathrm{pH}$ values for 5 of the 49 grid wells sampled ( 1 in the BV study area, 1 in the CD study area, and 3 in the LUB study area) in the CLUB study unit were outside of the $S M C L-U S$ range for $\mathrm{pH}(<6.5$ or $>8.5$ ) (table 4). L aboratory $\mathrm{pH}$ values may be dissimilar to field $\mathrm{pH}$ values because the $\mathrm{pH}$ of groundwater may change upon removal from the ambient environment and exposure to the atmosphere.

Field specific-conductance values for 18 of 49 of the CLUB study-unit grid-well samples were greater than the recommended SM CL-CA of 900 microsiemens per centimeter $(\mu \mathrm{S} / \mathrm{cm})$ (approximately 37 percent) (table 4). Field specific-conductance values for five of seven grid-well samples in the BV study area were greater than the recommended SM CL-CA, and two of these values also were greater than the upper SMCL-CA of $1,600 \mu \mathrm{S} / \mathrm{cm}$. Field specific-conductance values for 1 of 15 grid-well samples in the $C D$ study area were greater than the recommended SMCL-CA. Field specific-conductance values for 12 of 27 grid-well samples in the LUB study area were greater than the recommended SM CL-CA, and 3 of these values also were greater than the upper SM CL-CA .

\section{Organic Constituents}

V OCs are present in paints, solvents, fuels, fuel additives, refrigerants, fumigants, and disinfected water and are characterized by their tendency to evaporate. V OCs generally persist longer in groundwater than in surface water because groundwater is isolated from the atmosphere.

Of the $85 \mathrm{~V} \mathrm{OCs}$ analyzed, 8 were detected in the CLUB study-unit groundwater samples; all detections in samples were less than health-based benchmarks (table 5). One or more V OCs were detected in 17 of the 49 CLUB study-unit grid wells sampled (about 35 percent detection frequency). Three V OCs, including chloroform (trichloromethane), were detected in two of the seven grid wells sampled in the BV study area (approximately 29 percent). Chloroform is among the most commonly detected $\mathrm{V} O \mathrm{Cs}$ in groundwater nationally (Zogorski and others, 2006). V OCs were detected in 3 of the 15 grid wells sampled in the CD study area (20 percent); chloroform was detected in all 3 grid wells in which V OCs were detected. V OCs were detected in 12 of the 27 grid wells sampled in the LUB study area (approximately 44 percent). Chloroform and perchloroethene (PCE) were detected in more than 10 percent of the grid wells sampled in the LUB study area. Chloroform and 1,2,4-trimethylbenzene were the only $\mathrm{V} O \mathrm{C}$ s detected in one of the three understanding well samples (table 5).

Pesticides include herbicides, insecticides, and fungicides and are used to control weeds, insects, fungi, and other pests in agricultural, urban, and suburban settings. Of the 63 pesticides and pesticide degradates analyzed at 47 of the 49 grid wells in the CLUB study unit, 3 pesticides (atrazine, simazine, and metolachlor) and 3 pesticide degradates (3,4-dichloroaniline, deethylatrazine, and dieldrin) were detected in groundwater samples; all detections were less than health-based benchmarks (table 6). A trazine, simazine, and deethylatrazine are among the nation's most commonly detected pesticide compounds in groundwater (Gilliom and others, 2006). One or more pesticide compounds were detected in 5 of $47 \mathrm{grid}$ wells sampled in the CLUB study unit (about 11 percent detection frequency). Four pesticide compounds were detected in 1 grid well sampled in the CD study area. Pesticide and (or) pesticide degradates were detected in 4 of 27 grid wells sampled in the LUB study area (approximately 15 percent). No pesticides and (or) pesticide degradates were detected in any of the seven grid wells sampled in the BV study area or in the three understanding wells sampled in the CLUB study unit.

Pharmaceutical compounds were not detected at concentrations greater than or equal to method detection limits in the CLUB study unit. Fram and Belitz (2011) present all results for pharmaceutical compounds in groundwater samples collected for the first 28 GAMA-PBP study units (May 2004 through M arch 2010).

\section{Constituents of Special Interest}

Perchlorate and NDM A are constituents of special interest in California because they may adversely affect water quality and recently have been detected in water supplies (California Department of Public Health, 2008b). Perchlorate was analyzed for at all 52 wells in the CLUB study unit and was detected in 41 of 49 grid wells sampled (about 84 percent detection frequency; table 7). Perchlorate was detected in 4 of 7 grid wells sampled in the BV study area (approximately 57 percent). Perchlorate was detected in 14 of 15 grid wells sampled in the CD study area (approximately 93 percent). Perchlorate was detected in 23 of 27 grid wells sampled in the LUB study area (approximately 85 percent). Perchlorate was not measured at concentrations greater than the M CL-CA of 6 micrograms per liter $(\mu \mathrm{g} / \mathrm{L})$ in any of the grid or understanding wells sampled in the CLUB study unit. NDM A was sampled for at the 24 slow wells in the CLUB study unit and was not detected in any of the wells. A s a result, NDMA is not included in table 7. 


\section{Inorganic Constituents}

Unlike the organic constituents and the constituents of special interest, inorganic constituents are naturally present in groundwater, although their concentrations may be influenced by human activities. Inorganic constituents were sampled for on the slow sampling schedule in the CLUB study unit and the fast sampling schedule in the LUB study area.

Regulatory health-based or non-regulatory health-based benchmarks have been established for 18 of 24 trace elements and for one of the major and minor ions analyzed in this study (table $3 \mathrm{E}, \mathrm{G}$ ). Of these 18 constituents with health-based benchmarks, all detections of 13 constituents had concentrations less than their respective benchmarks (table 8). A rsenic, boron, molybdenum, uranium, and fluoride were detected at concentrations greater than healthbased benchmarks in samples from the CD and LUB study areas. Trace el ements were not detected at concentrations greater than established health-based benchmarks in the BV study area well samples (table 8).

A rsenic concentrations greater than the M CL -US of $10 \mu \mathrm{g} / \mathrm{L}$ were detected in seven grid wells sampled (one in the CD study area and six in the LUB study area; table 8). A rsenic was measured at a concentration greater than the M CL-US in one LUBU well sample.

Boron concentrations greater than the CDPH notification level ( $\mathrm{NL}-\mathrm{CA}$ ) of $1,000 \mu \mathrm{g} / \mathrm{L}$ were detected in four grid wells sampled in the LUB study area (table 8).

$M$ olybdenum concentrations greater than the HAL-US of $40 \mu \mathrm{g} / \mathrm{L}$ were detected in six grid wells sampled (one in the CD study area and five in the LUB study area; table 8). Additionally, molybdenum was measured at a concentration greater than the HAL-US in one LUBU well sample.

U ranium concentrations greater than the M CL-US of $30 \mu \mathrm{g} / \mathrm{L}$ were detected in two grid wells sampled (one in the CD study area and one in the LUB study area; table 8).

Fluoride is the only major ion with a regulatory health-based benchmark (M CL-CA of 2 milligrams per liter $[\mathrm{mg} / \mathrm{L}])$; it was detected at a concentration greater than the $M C L-C A$ in nine grid wells sampled (one in the CD study area and eight in the LUB study area; table 10). Fluoride was detected at a concentration greater than the $\mathrm{MCL}-\mathrm{CA}$ in one LUBU well sample.

Nutrients (nitrogen and phosphorus) present in groundwater can affect biological activity in aquifers and in surface-water bodies that receive groundwater discharge. Inorganic nitrogen may be present in the form of ammonia, nitrite, or nitrate, depending on the oxidation-reduction state of the groundwater. High concentrations of nitrate can adversely affect human health, particularly the heal th of infants.

A ll concentrations of ammonia, nitrite, and nitrate measured in the CLUB study-unit wells were less than health-based benchmarks, with the exception of nitrite plus nitrate $\left(\mathrm{NO}_{2}{ }^{-}+\mathrm{NO}_{3}{ }^{-}\right)$, as nitrogen, detected at a concentration greater than the M CL-US of $10 \mathrm{mg} / \mathrm{L}$ in one grid well sampled in the LUB study area (table 9).
The levels of certain trace elements, major-ion composition, and TDS content in groundwater affect the aesthetic properties of water, such as taste, color, and odor, and the technical properties of water, such as scaling and staining. A lthough there are no adverse health effects directly associated with these properties, they may reduce consumer satisfaction with the water or may have economic effects. The CDPH has established non-enforceable benchmarks (SM CL-CAs) that are based on aesthetic properties rather than on human-heal th concerns for iron, manganese, silver, zinc, chloride, sulfate, and TDS. I ron and manganese are trace elements whose concentrations are affected by the oxidationreduction state of the groundwater. Precipitation of minerals containing iron or manganese may cause orange, brown, or black staining of surfaces.

I ron concentrations greater than the SM CL-CA of $300 \mu \mathrm{g} / \mathrm{L}$ were not detected in any of the wells in the CLUB study unit (table 8). $M$ anganese concentrations greater than the SMCL-CA of $50 \mu \mathrm{g} / \mathrm{L}$ were detected in one LUB study-area grid-well sample (table 8).

Chloride concentrations greater than the recommended SM CL-CA benchmark of $250 \mathrm{mg} / \mathrm{L}$ were detected in three grid wells sampled in the LUB study area (table 10). One of these three well samples al so had chloride concentrations greater than the upper SM CL-CA benchmark of $500 \mathrm{mg} / \mathrm{L}$.

Sulfate concentrations greater than the recommended SM CL -CA benchmark of $250 \mathrm{mg} / \mathrm{L}$ were detected in six grid wells sampled (one in the BV study area and five in the LUB study area; table 10).

TDS concentrations greater than the recommended SM CL -CA benchmark of $500 \mathrm{mg} / \mathrm{L}$ were detected in 20 grid wells sampled ( 3 in the BV study area, 1 in the CD study area, and 16 in the LUB study area; table 10). TDS concentrations greater than the upper SM CL-CA benchmark of $1,000 \mathrm{mg} / \mathrm{L}$ were detected in 2 of the 16 grid wells sampled in the LUB study area.

Silver and zinc were not detected at concentrations greater than the corresponding SM CL-CA in any of wells in the CLUB study unit (table 8). A dditionally, all iron, manganese, chloride, sulfate, and TDS concentrations in the three understanding wells in the CLUB study unit were less than the SM CL-CA (tables 8, 10).

Chromium occurs as different species depending on the oxidation-reduction state of the groundwater. The oxidized and reduced species have different solubilities in groundwater and may have different effects on human heal th. The relative proportions of the species can be used to aid in interpretation of the oxidation-reduction state of the aquifer. Concentrations of chromium (total) and (or) the concentrations of $\mathrm{Cr}-\mathrm{VI}$ are reported in tables 11 and $\underline{12}$.

Species of inorganic chromium were sampled for at seven slow wells (three CD study-area grid wells and four LUB study-area grid wells) in December 2008. Chromium (total) and Cr-VI were detected in five grid-well samples in the CLUB study unit (three in the CD study area and two in the LUB study area; table 11). Concentrations of chromium 
(total) reported by the NW Q in table 8 are considered to be more accurate than the concentrations reported by the USGS N ational Research Program (NRP) Trace M etal L aboratory (TM L), B oulder, Colorado, in table 11 (see the appendix section titled "Constituents on M ultiple A nalytical Schedules").

$\mathrm{Cr}-\mathrm{VI}$ is a heavy metal that is frequently detected at Iow levels in California's drinking-water supply (California Environmental Protection A gency, 2009). Cr-VI has a variety of natural sources (oxidation of chromium-III, serpentine-containing rocks, and chromium-containing geologic formations) and anthropogenic sources (chrome-plating liquid wastes, dye and paint pigments, wood preservatives, chemical manufacturing, and the combustion of natural gas, oil, and coal) (California Environmental Protection A gency, 2009; California State Water Resources Control Board, 2009b). In January 2001, CDPH identified $\mathrm{Cr}-\mathrm{VI}$ as an unregulated chemical requiring monitoring (California State Water Resources Control B oard, 2009b).

Cr-VI was sampled for at 17 slow wells ( 3 BV study-area grid wells, 6 CD study-area grid wells, 7 LUB study-area grid wells, and the BVU well) in the CLUB study unit starting in $O$ ctober 2009. These samples were analyzed at TestA merica L aboratories, Inc. (TA LIR), I rvine, California, rather than at the NRP-TML in order to fulfill a contractual obligation with the NW QL. Cr-VI was detected in seven grid wells sampled in the CLUB study unit (four in the CD study and three in the LUB study area; table 12). Cr-V I also was detected in the BVU well sampled.

\section{Isotopic Tracers and Dissolved Noble Gases}

The isotopic ratios, activities, and abundances of many elements and the concentrations of dissolved gases (including noble gases) may be used as tracers of hydrologic processes (Clark and Fritz, 1997).

The isotopic ratios of hydrogen and oxygen in water (table 13) aid in the interpretation of the sources of groundwater recharge. These stable-isotope ratios reflect the altitude, latitude, and temperature of precipitation and also the extent of evaporation of the water in surface-water bodies or soils prior to infiltration into the aquifer.

Stable-isotope ratios of boron in water may be useful in distinguishing the sources of boron in aquifers. $A$ geochemically-based classification of the source of boron in groundwater could potentially determine the similarity of boron to known sources or mixtures between known sources, or classify whether the relative age of the groundwater predated potential sources.

Stable-isotope ratios of strontium in water reflect the amount of strontium (and other inorganic constituents) the aquifer materials are contributing to the groundwater system. In regions that have diverse geology, strontium isotope ratios may aid in estimating groundwater-flow paths.
Tritium activities (table 13), helium isotope ratios, and carbon-14 abundance (table 13) al so provide information about the age (time since recharge) of groundwater. Tritium is a short-lived radioactive isotope of hydrogen that is incorporated into the water molecule. Low levels of tritium are produced continuously by interaction of cosmic radiation with the Earth's atmosphere, and a large amount of tritium was produced as a result of atmospheric testing of nuclear weapons between 1952 and 1963. Thus, concentrations of tritium greater than background generally indicate the presence of water recharged after the early 1950s. Helium isotope ratios are used in conjunction with tritium concentrations to estimate ages for young groundwater.

Carbon-14 (table 13) is a radioactive isotope of carbon. Low levels of carbon-14 are produced continuously by interaction of cosmic radiation with the Earth's atmosphere and incorporated into atmospheric carbon dioxide. Carbon dioxide dissolves in precipitation, surface water, and groundwater exposed to the atmosphere, thereby entering the hydrologic cycle. B ecause carbon-14 decays with a half-life of approximately 5,700 years, low activities of carbon-14, relative to modern values, generally indicate a presence of groundwater that is several thousand years old or more.

$G$ ases dissolve in water that is in contact with the atmosphere, and the solubilities of the different gas species vary with temperature. Concentrations of dissolved noble gases are used to estimate the conditions of groundwater recharge, particularly the temperature of the recharge water.

Of the isotopic tracer constituents analyzed for this study, tritium is the only one with a health-based benchmark. All measured tritium activities in samples from the well samples in the CLUB study unit were more than three orders of magnitude less than the M CL-CA benchmark (table 13).

\section{Radioactive Constituents}

Radioactivity is the release of energy or energetic particles during changes in the structure of the nucleus of an atom. M ost radioactivity in groundwater comes from decay of naturally-occurring isotopes of uranium and thorium that are present in minerals in the sediments or fractured rocks of the aquifer. U ranium and thorium decay in a series of steps eventually forming stable isotopes of lead (Soddy, 1913; Faure and $M$ ensing, 2005). R adium-226, radium-228, and radon-222 are radioactive isotopes formed during the uranium or thorium decay series. In each step in the decay series, one radioactive element turns into a different radioactive element by emitting an al pha or a beta particle from its nucleus. For example, radium-226 emits an al pha particle and therefore turns into radon-222. Radium-228 decays to form actinium-228 by emission of a beta particle. The al pha and beta particles emitted during radioactive decay are hazardous to human health because these energetic particles may damage cells. Radiation damage to cell DNA may increase the risk of getting cancer. 
A ctivity often is used instead of concentration for reporting the presence of radioactive constituents. A ctivity of radioactive constituents in groundwater is measured in units of picocuries per liter ( $\mathrm{pCi} / \mathrm{L}$ ), and $1 \mathrm{pCi} / \mathrm{L}$ is approximately equal to two atoms decaying per minute. The number of atoms decaying is equal to the number of alpha or beta particles emitted.

Radon-222 was sampled for at 22 slow grid wells and 1 slow understanding well in the CLUB study unit (table 14A). Radium isotopes (radium-226 and radium-228) and gross alpha and gross beta radioactivity were sampled for at 23 slow grid wells and 1 slow understanding well (table 14B, C).

Radon-222 activities for all wells sampled in the CLUB study unit were less than the proposed M CL-US of 4,000 pCi/L (table 14A). The proposed M CL-US will apply if the state or local water agency has an approved multimedia mitigation program to address radon levels in indoor air (U.S. Environmental Protection A gency, 1999).

Radium isotope (radium-226 and radium-228) activities for all of the wells sampled in the CLUB study unit were less than the MCL-US of $5 \mathrm{pCi} / \mathrm{L}$ (table 14B). The $M C L$-US benchmark for radium is the sum of radium-226 and radium-228.

Gross al pha and gross beta radioactivity activities for most of the wells sampled in the CLUB study unit were less than established health-based benchmarks (table 14C). Exceptions include two detections of gross al pha radioactivity (72-hour count) and one detection of gross alpha radioactivity (30-day count) greater than the M CL-US of $15 \mathrm{pCi} / \mathrm{L}$ in two grid wells sampled in the CD study area and two detections of gross al pha radioactivity (72-hour count) in two grid wells sampled in the LUB study area.

\section{Future Work}

Subsequent reports for the CLUB study unit will be focused on assessment of the data presented in this report by using a variety of statistical, qualitative, and quantitative approaches to evaluate the natural and human factors affecting groundwater quality in the CLUB study unit. Water-quality data contained in the CDPH databases will be compiled, evaluated, and used in combination with the data that are presented in this report. A dditionally, these subsequent reports will include the results for the analysis of stable isotopes of boron and strontium in water and the LLNL results (dissolved noble gases, tritium, and helium isotope ratios) for the CLUB study unit.

\section{Summary}

G roundwater quality in the 12,103-square-mile B orrego Valley, Central Desert, and L ow-U se B asins of the M ojave and Sonoran Deserts (CLUB) study unit was investigated by the U.S. Geological Survey (USGS) from December 2008 to $M$ arch 2010, as part of the California State Water Resources Control B oard (SW RCB) Groundwater A mbient M onitoring and A ssessment (GA M A) Program's Priority B asin Project (PBP). The GA M A Program was created to provide a comprehensive baseline of groundwater quality in the state. The GA M A -PBP was created as a result of the Groundwater Quality M onitoring A ct of 2001 (Sections 10780-10782.3 of the California Water Code, A ssembly Bill 599) to assess and monitor the quality of groundwater. The GA M A-PBP is being conducted by the USGS in cooperation with the SWRCB and Lawrence Livermore N ational L aboratory (LLNL).

The GAMA CLUB study was designed to provide a spatially unbiased assessment of untreated-groundwater quality in the primary aquifer systems and to facilitate statistically consistent comparisons of untreated-groundwater quality throughout California. The primary aquifer systems (hereinafter referred to as primary aquifers) are defined as parts of aquifers corresponding to the perforation intervals of wells listed in the California Department of Public Health (CDPH) database for the CLUB study unit. The quality of groundwater in shallow or deep water-bearing zones may differ from that in the primary aquifers; shallow groundwater may be more vulnerable to surficial contamination.

This study did not attempt to evaluate the quality of water delivered to consumers; after withdrawal from the ground, water typically is treated, disinfected, and blended with other waters to maintain acceptable water quality. Regulatory benchmarks apply to treated water that is served to the consumer, not to untreated groundwater. However, to provide some context for the results, concentrations of constituents measured in the untreated groundwater were compared with regulatory and non-regulatory heal th-based benchmarks established by the U.S. Environmental Protection A gency (USEPA) and CDPH and non-regulatory benchmarks established for aesthetic concerns by the CDPH.

The CLUB study unit is located within the M ojave and Sonoran Deserts in the Desert hydrologic province and includes 47 groundwater basins and subbasins defined by the California Department of Water Resources. The CLUB study included assessment of the groundwater quality from 52 wells in San Bernardino, Riverside, San Diego, and Imperial Counties, California. Forty-nine of the wells were selected using a randomized grid approach to achieve statistically unbiased representation of groundwater used for public drinking-water supplies (grid wells). Three of the wells were selected to provide additional sampling density to aid in understanding processes affecting groundwater quality (understanding wells). 
G roundwater samples were analyzed for water-quality indicators, organic constituents, naturally-occurring inorganic constituents, and radioactive constituents. Naturally-occurring isotopes and dissolved noble gases also were measured to provide a dataset that will be used to interpret the sources and ages of the sampled groundwater. In total, 223 constituents and 12 water-quality indicators were measured for this study. This report describes the sampling, analytical, and quality-assurance methods used in the study and presents the results of the chemical analyses of the groundwater samples.

Three types of quality-control samples (blanks, replicates, and matrix spikes) were collected at up to 10 percent of the wells in the CLUB study unit, and the results for these samples were used to evaluate the quality of the data for the groundwater samples. Field blanks rarely contained detectable concentrations of any constituent, suggesting that contamination from sample collection procedures was not a significant source of bias in the data for the groundwater samples. Replicate samples generally were within the limits of acceptable analytical reproducibility. $M$ edian matrix-spike recoveries were within the acceptable range (70 to 130 percent) for approximately 85 percent of the compounds.

O rganic constituents were sampled for at all 49 grid wells in the CLUB study unit, and all detected concentrations were less than health-based benchmarks. Trace elements, nutrients, and major and minor ions were sampled for at 39 grid wells, and radioactive constituents were sampled for at 23 grid wells. M ost detections were at concentrations less than health-based benchmarks.

In the B orrego Valley study area, all detected concentrations of trace elements, major and minor ions, and radioactive constituents were less than health-based benchmarks.

In the Central Desert study area, one detection of arsenic was greater than the USEPA maximum contaminant level (MCL-US), one detection of molybdenum was greater than the USEPA lifetime health advisory level (HAL-US), one detection of uranium was greater than the M CL-US, one detection of fluoride measured greater than the CDPH maximum contaminant level (MCL-CA), and two detections of gross al pha radioactivity (72-hour count) and one detection of gross al pha radioactivity (30-day count) were greater than the MCL-US.

In the Low-U se Basins of the M ojave and Sonoran Deserts study area, detections of arsenic were greater than the M CL-US, four detections of boron were greater than the CDPH notification level (NL-CA), five detections of molybdenum were greater than the HAL-US, one detection of uranium was at a concentration greater than the M CL-US, eight detections of fluoride were greater than the MCL-CA, one detection of nitrite plus nitrate $\left(\mathrm{NO}_{2}{ }^{-}+\mathrm{NO}_{3}{ }^{-}\right)$, as nitrogen, was greater than the M CL-US, and two detections of gross al pha radioactivity (72-hour count) were greater than the MCL-US.
M ost of the samples from the CLUB study-unit wells collected for trace elements and major ions had measured concentrations less than the non-enforceable benchmarks set for aesthetic concerns.

In the B orrego Valley study area, one detection of sulfate was greater than the recommended CDPH secondary maximum contaminant level (SM CL-CA), and three detections of TDS were greater than the recommended SM CL-CA.

In the Central Desert study area, one detection of TDS was greater than the recommended SM CL-CA .

In the L ow-U se Basins of the M ojave and Sonoran Deserts study area, 1 detection of manganese was greater than the SM CL-CA, 3 detections of chloride were greater than the recommended SM CL-CA ( 1 of the detections was greater than the upper SM CL-CA ), 5 detections of sulfate were greater than the recommended SM CL-CA, and 16 detections of TDS were greater than the recommended SM CL-CA (2 of the detections were greater than the upper SM CL-CA).

In the three understanding wells in the CLU B study unit, one detection of arsenic was greater than the M CL -US, one detection of molybdenum was greater than the HAL-US, and one detection of fluoride was greater than the MCL-CA.

\section{Acknowledgments}

The authors thank the following cooperators for their support: the California State Water Resources Control B oard, California Department of Public Health, California Department of Water Resources, and L aw rence L ivermore $\mathrm{N}$ ational Laboratory. We especially thank the well owners and water purveyors for allowing the U.S. Geological Survey to collect samples from their wells.

\section{References Cited}

A dams, D.K., 1997, Review of variabilty in the North A merican M onsoon- Impact of climate change and land use in the southwestern U nited States, U.S. Global Change R esearch Program, accessed J anuary 10, 2011, at http:// geochange.er.usgs.gov/sw/changes/natural/monsoon/.

A merican Public Health A ssociation, 1998, Standard methods for the examination of water and wastewater (20th ed.): Washington, D.C., A merican Public Health A ssociation, A merican Water Works A ssociation, and Water Environment Federation, p. 3-37-3-43.

A merican Society for Testing and M aterials, 1998, Water and environmental technology, in A nnual book of A STM standards: Philadel phia, Pa., A merican Society for Testing and $M$ aterials, section 11.02 (Water II), p. 664-666. 
A nderson, R.L., 1987, Practical statistics for analytical chemists: N ew York, Van N ostrand Reinhold Company, Inc., $315 \mathrm{p}$.

Ball, J.W., and M cCleskey, R.B., 2003a, A new cationexchange method for accurate field speciation of hexaval ent chromium: U.S. Geological Survey Water-Resources Investigations Report 03-4018, 17 p.

Ball, J.W., and M cCleskey, R.B., 2003b, A new cationexchange method for accurate field speciation of hexavalent chromium: Talanta, v. 61, p. 305-313.

B elitz, K enneth, Dubrovsky, N.M ., Burow, K .R., J urgens, B ryant, and J ohnson, Tyler, 2003, Framework for a groundwater quality monitoring and assessment program for California: U.S. Geological Survey Water-Resources Investigations Report 03-4166, 78 p.

B ennett, P.A., B ennett, G.L., V, and B elitz, K enneth, 2009, Groundwater qual ity data for the N orthern Sacramento Valley, 2007-Results from the California GA M A Program: U.S. G eological Survey Data Series 452, 90 p.

Bullen, T.D., K rabbenhoft, D.P., and K endall, Carol, 1996, $K$ inetic and mineralogic controls on the evolution of groundwater chemistry and ${ }^{87} \mathrm{Sr} / 86 \mathrm{Sr}$ in a sandy silicate aquifer, northern Wisconsin, USA: Geochimica et Cosmochimica A cta, v. 60, no. 10, p. 1807-1821.

California Department of Public H ealth, 2008a, California drinking water-related laws - D rinking water-related regulations, Title 22: California Department of Public Health, accessed October 6, 2010, at http://www.cdph. ca.gov/certlic/drinkingwater/Pages/L aw book.aspx.

California Department of Public H ealth, 2008b, Drinking water notification levels-Notification levels: California Department of Public Health, accessed October 6, 2010, at http://www.cdph.ca.gov/certlic/drinkingwater/Pages/ NotificationLevels.aspx.

California Department of Water Resources, 2003a, California's groundwater update 2003: California D epartment of Water Resources B ulletin 118, 246 p., accessed O ctober 5, 2010, at http://www.water.ca.gov/groundwater/bulletin118/ update2003.cfm.

California Department of Water Resources, 2003b, California's groundwater-Individual basin descriptions, M orongo Valley: California Department of Water Resources B ulletin 118, accessed N ovember 9, 2010, at http://www.water.ca.gov/pubs/groundwater/bulletin 118/ basindescriptions/7-20.pdf.
California Department of Water Resources, 2003c, California's groundwater-Individual basin descriptions, Caves Canyon Valley: California Department of Water Resources Bulletin 118, accessed December 2, 2010, at http://www.water.ca.gov/pubs/groundwater/bulletin_118/ basindescriptions/6-38.pdf.

California D epartment of Water Resources, 2004a, California's groundwater-Individual basin descriptions, B orrego Valley: California Department of Water Resources Bulletin 118, accessed October 12, 2010, at http:/l www.water.ca.gov/pubs/groundwater/bulletin_118/ basindescriptions/7-24.pdf.

California D epartment of Water Resources, 2004b, California's groundwater-Individual basin descriptions, Copper M ountain Valley: California Department of Water Resources Bulletin 118, accessed N ovember 9, 2010, at http://www.water.ca.gov/pubs/groundwater/bulletin_118/ basindescriptions/7-11.pdf.

California Department of Water Resources, 2004c, California's groundwater-Individual basin descriptions, Warren Valley: California Department of Water R esources Bulletin 118, accessed N ovember 9, 2010, at http://www.water.ca.gov/ pubs/groundwater/bulletin_118/basindescriptions/7-12.pdf.

California D epartment of Water Resources, 2004d, California's groundwater-Individual basin descriptions, Deadman Valley, Surprise Spring Subbasin: California Department of Water Resources B ulletin 118, accessed N ovember 9, 2010, at http://www.water.ca.gov/pubs/ groundwater/bulletin_118/basindescriptions/7-13.02.pdf.

California Department of Water Resources, 2004e, California's groundwater-Individual basin descriptions, A mes Valley: California Department of Water R esources Bulletin 118, accessed N ovember 9, 2010, at http://www.water.ca.gov/ pubs/groundwater/bulletin_118/basindescriptions/7-16.pdf.

California Department of Water Resources, 2004f, California's groundwater-Individual basin descriptions, J oshua Tree: California Department of Water R esources Bulletin 118, accessed N ovember 9, 2010, at http://www.water.ca.gov/ pubs/groundwater/bulletin_118/basindescriptions/7-62.pdf.

California D epartment of Water Resources, 2004g, California's groundwater-Individual basin descriptions, U pper Kingston Valley: California Department of Water Resources Bulletin 118, accessed December 2, 2010, at http://www.water.ca.gov/pubs/groundwater/bulletin 118/ basindescriptions/6-22.pdf.

California D epartment of Water Resources, 2004h, California's groundwater-Individual basin descriptions, Bicycle Valley: California Department of Water Resources Bulletin 118, accessed December 2, 2010, at http:/l www.water.ca.gov/pubs/groundwater/bulletin_118/ basindescriptions/6-25.pdf. 
California Department of Water Resources, 2004i, California's groundwater-Individual basin descriptions, Ivanpah Valley: California Department of Water R esources Bulletin 118, accessed December 2, 2010, at http:// www.water.ca.gov/pubs/groundwater/bulletin 118/ basindescriptions/6-30.pdf.

California D epartment of Water Resources, 2004j, California's groundwater-Individual basin descriptions, B roadwell Valley: California Department of Water R esources Bulletin 118, accessed December 2, 2010, at http:// www.water.ca.gov/pubs/groundwater/bulletin_118/ basindescriptions/6-32.pdf.

California Department of Water Resources, 2004k, California's groundwater-Individual basin descriptions, Soda Lake Valley: California Department of Water Resources Bulletin 118, accessed December 2, 2010, at http://www.water.ca.gov/pubs/groundwater/bulletin_118/ basindescriptions/6-33.pdf.

California D epartment of Water Resources, 2004l, California's groundwater-Individual basin descriptions, L angford Valley, Langford Well Lake Subbasin: California Department of Water Resources B ulletin 118, accessed December 2, 2010, at http://www.water.ca.gov/pubs/ groundwater/bulletin_118/basindescriptions/6-36.01.pdf.

California Department of Water Resources, 2004m, California's groundwater-Individual basin descriptions, L angford Valley, Irwin Subbasin: California D epartment of Water R esources Bulletin 118, accessed December 2, 2010, at http://www.water.ca.gov/pubs/groundwater/bulletin_118/ basindescriptions/6-36.02.pdf.

California Department of Water Resources, 2004n, California's groundwater-Individual basin descriptions, Fremont Valley: California Department of Water Resources Bulletin 118, accessed December 2, 2010, at http:// www.water.ca.gov/pubs/groundwater/bulletin 118/ basindescriptions/6-46.pdf.

California Department of Water Resources, 20040, California's groundwater-Individual basin descriptions, Superior Valley: Cal ifornia Department of Water Resources Bulletin 118, accessed December 2, 2010, at http:// www.water.ca.gov/pubs/groundwater/bulletin_118/ basindescriptions/6-49.pdf.

California D epartment of Water Resources, 2004p, California's groundwater-Individual basin descriptions, Pilot K nob Valley: California Department of Water Resources Bulletin 118, accessed December 2, 2010, at http://www.water.ca.gov/pubs/groundwater/bulletin_118/ basindescriptions/6-51.pdf.
California Department of Water R esources, 2004q, California's groundwater-Individual basin descriptions, L anfair Valley: California Department of Water Resources B ulletin 118, accessed December 2, 2010, at http:/l www.water.ca.gov/pubs/groundwater/bulletin_118/ basindescriptions/7-1.pdf.

California Department of Water R esources, 2004r, California's groundwater-Individual basin descriptions, Fenner Valley: California Department of Water Resources B ulletin 118, accessed December 2, 2010, at http://www.water.ca.gov/ pubs/groundwater/bulletin_118/basindescriptions/7-2.pdf.

California Department of Water R esources, 2004s, California's groundwater-Individual basin descriptions, Chuckwalla Valley: California Department of Water Resources Bulletin 118, accessed December 2, 2010, at http://www.water.ca.gov/pubs/groundwater/bulletin 118/ basindescriptions/7-5.pdf.

California Department of Water R esources, 2004t, California's groundwater-Individual basin descriptions, Pinto Valley: California Department of Water Resources B ulletin 118, accessed December 2, 2010, at http://www.water.ca.gov/ pubs/groundwater/bulletin_118/basindescriptions/7-6.pdf.

California Department of Water R esources, 2004u, California's groundwater-Individual basin descriptions, B ristol Valley: California Department of Water Resources Bulletin 118, accessed December 2, 2010, at http:/l www.water.ca.gov/pubs/groundwater/bulletin_118/ basindescriptions/7-8.pdf.

California Department of Water Resources, 2004v, California's groundwater-Individual basin descriptions, Dale Valley: California Department of Water Resources B ulletin 118, accessed December 2, 2010, at http://www.water.ca.gov/ pubs/groundwater/bulletin_118/basindescriptions/7-9.pdf.

California Department of Water R esources, 2004w, California's groundwater-Individual basin descriptions, Twentynine Palms: California Department of Water Resources Bulletin 118, accessed December 2, 2010, at http://www.water.ca.gov/pubs/groundwater/bulletin_118/ basindescriptions/7-10.pdf.

California Department of Water R esources, 2004x, California's groundwater-Individual basin descriptions, Deadman Valley, D eadman Lake Subbasin: California Department of Water Resources Bulletin 118, accessed December 2, 2010, at http://www.water.ca.gov/pubs/ groundwater/bulletin_118/basindescriptions/7-13.01.pdf.

California Department of Water Resources, 2004y, California's groundwater-Individual basin descriptions, J ohnson Valley, Soggy Lake Subbasin: California Department of Water Resources Bulletin 118, accessed December 2, 2010, at http://www.water.ca.gov/pubs/groundwater/bulletin_118/ basindescriptions/7-18.01.pdf. 
California Department of Water Resources, 2004z, California's groundwater-Individual basin descriptions, Johnson Valley, U pper J ohnson Valley Subbasin: California Department of Water Resources B ulletin 118, accessed December 2, 2010, at http://www.water.ca.gov/pubs/ groundwater/bulletin_118/basindescriptions/7-18.02.pdf.

California Department of Water Resources, 2004aa, California's groundwater-Individual basin descriptions, L ucerne Vall ley: California Department of Water Resources Bulletin 118, accessed December 2, 2010, at http:// www.water.ca.gov/pubs/groundwater/bulletin_118/ basindescriptions/7-19.pdf.

California Department of Water Resources, 2004bb, California's groundwater-Individual basin descriptions, O cotillo-Clark Valley: California Department of Water Resources B ulletin 118, accessed December 2, 2010, at http://www.water.ca.gov/pubs/groundwater/bulletin_118/ basindescriptions/7-25.pdf.

California Department of Water Resources, 2004cc, California's groundwater-Individual basin descriptions, San Felipe Valley: California Department of Water Resources B ulletin 118, accessed December 2, 2010, at http://www.water.ca.gov/pubs/groundwater/bulletin_118/ basindescriptions/7-27.pdf.

California Department of Water Resources, 2004dd, California's groundwater-Individual basin descriptions, Vallecito-Carrizo Valley: California Department of Water Resources B ulletin 118, accessed December 2, 2010, at http://www.water.ca.gov/pubs/groundwater/bulletin 118/ basindescriptions/7-28.pdf.

California Department of Water Resources, 2004ee, California's groundwater-Individual basin descriptions, Coyote Wells Valley: California D epartment of Water Resources B ulletin 118, accessed December 2, 2010, at http://www.water.ca.gov/pubs/groundwater/bulletin_118/ basindescriptions/7-29.pdf.

California Department of Water Resources, 2004ff, California's groundwater-Individual basin descriptions, Imperial Valley: California Department of Water Resources Bulletin 118, accessed December 2, 2010, at http:// www.water.ca.gov/pubs/groundwater/bulletin_118/ basindescriptions/7-30.pdf.

California Department of Water Resources, 2004gg, California's groundwater-Individual basin descriptions, Orocopia Valley: California D epartment of Water Resources Bulletin 118, accessed December 2, 2010, at http://www.water.ca.gov/pubs/groundwater/bulletin_118/ basindescriptions/7-31.pdf.
California D epartment of Water Resources, 2004hh, California's groundwater-Individual basin descriptions, East Salton Sea: California Department of Water Resources Bulletin 118, accessed December 2, 2010, at http:/l www.water.ca.gov/pubs/groundwater/bulletin_118/ basindescriptions/7-33.pdf.

California D epartment of Water Resources, 2004ii, California's groundwater-Individual basin descriptions, A mos Valley: California Department of Water R esources Bulletin 118, accessed December 2, 2010, at http:// www.water.ca.gov/pubs/groundwater/bulletin_118/ basindescriptions/7-34.pdf.

California D epartment of Water Resources, 2004jj, California's groundwater-Individual basin descriptions, O gilby Valley: California Department of Water Resources Bull etin 118, accessed December 2, 2010, at http:// www.water.ca.gov/pubs/groundwater/bulletin_118/ basindescriptions/7-35.pdf.

California D epartment of Water Resources, 2004kk, California's groundwater-Individual basin descriptions, A rroyo Seco Valley: California Department of Water Resources Bulletin 118, accessed December 2, 2010, at http://www.water.ca.gov/pubs/groundwater/bulletin_118/ basindescriptions/7-37.pdf.

California D epartment of Water Resources, 2004II, California's groundwater-Individual basin descriptions, Quien Sabe Point Valley: California Department of Water Resources Bulletin 118, accessed December 2, 2010, at http://www.water.ca.gov/pubs/groundwater/bulletin_118/ basindescriptions/7-40.pdf.

California Department of Water Resources, 2004mm, California's groundwater-Individual basin descriptions, Calzona Valley: California Department of Water Resources Bulletin 118, accessed December 2, 2010, at http:// www.water.ca.gov/pubs/groundwater/bulletin_118/ basindescriptions/7-41.pdf.

California D epartment of Water Resources, 2004nn, California's groundwater-Individual basin descriptions, Vidal Valley: California Department of Water Resources Bulletin 118, accessed December 2, 2010, at http:// www.water.ca.gov/pubs/groundwater/bulletin_118/ basindescriptions/7-42.pdf.

California D epartment of Water Resources, 200400, California's groundwater-Individual basin descriptions, Chemehuevi Valley: California Department of Water Resources Bulletin 118, accessed December 2, 2010, at http://www.water.ca.gov/pubs/groundwater/bulletin_118/ basindescriptions/7-43.pdf. 
California Department of Water Resources, 2004pp, California's groundwater-Individual basin descriptions, Jacumba Valley: California Department of Water Resources Bulletin 118, accessed December 2, 2010, at http://www.water.ca.gov/pubs/groundwater/bulletin_118/ basindescriptions/7-47.pdf.

California D epartment of Water Resources, 2004qq, California's groundwater-Individual basin descriptions, Lost Horse Valley: California Department of Water Resources Bulletin 118, accessed December 2, 2010, at http://www.water.ca.gov/pubs/groundwater/bulletin 118/ basindescriptions/7-51.pdf.

California D epartment of Water Resources, 2004rr, California's groundwater-Individual basin descriptions, Yaqui Well A rea: California Department of Water Resources Bulletin 118, accessed December 2, 2010, at http://www.water.ca.gov/pubs/groundwater/bulletin_118/ basindescriptions/7-56.pdf.

California D epartment of Water Resources, 2004ss, California's groundwater-Individual basin descriptions, $M$ ason Valley: California Department of Water Resources Bulletin 118, accessed December 2, 2010, at http:/l www.water.ca.gov/pubs/groundwater/bulletin_118/ basindescriptions/7-59.pdf.

California Environmental Protection A gency, 2009, Draft public health goal for hexavalent chromium, Office of Environmental Health H azard A ssessment Fact Sheet, accessed October 6, 2010, at http://www.oehha.ca.gov/ water/phg/pdf/H exChromfacts082009.pdf.

California Environmental Protection A gency, 2011, GA M A $G$ roundwater $A$ mbient $M$ onitoring and $A$ ssessment Program: State Water Resources Control B oard website, accessed February 14, 2011, at http://www.waterboards. ca.gov/water_issues/programs/gamal.

California State Water Resources Control B oard, 2003, Report to the Governor and Legislature-A comprehensive groundwater quality monitoring program for California: A ssembly Bill 599, M arch 2003, 121 p., accessed October 11, 2010, at http://www.waterboards.ca.gov/gama/ docs/final ab 599 rpt to legis 7 31 03.pdf.

California State Water Resources Control B oard, 2009a, Geotracker GA M A : State Water Resources Control B oard database, accessed February 14, 2011, at https://geotracker. waterboards.ca.gov/gamal.

California State Water Resources Control B oard, 2009b, Chromium VI, California State Water Resources Control B oard Groundwater Information Sheet, accessed October 6, 2010, at http://www.swrcb.ca.gov/water_issues/programs/ gama/docs/coc_hexchromcr6.pdf.
Childress, C.J .O., Foreman, W.T., Connor, B.F., and M al oney, T.J., 1999, N ew reporting procedures based on long-term method detection levels and some considerations for interpretations of water-quality data provided by the U.S. Geological Survey N ational Water Quality Laboratory: U.S. Geological Survey O pen-File Report 99-193, 19 p.

Clark, I.D., and Fritz, P., 1997, Environmental Isotopes in Hydrogeology: Boca Raton, Fla., CRC Press LLC, 328 p.

Connor, B.F., Rose, D.L., N oriega, M .C., M urtagh, L.K., and A bney, S.R., 1998, M ethods of analysis by the U.S. Geological Survey N ational Water Quality LaboratoryDetermination of 86 volatile organic compounds in water by gas chromatography/mass spectrometry, including detections less than reporting limits: U.S. Geological Survey O pen-File Report 97-829, 78 p.

Coplen, T.B ., 1994, Reporting of stable hydrogen, carbon, and oxygen isotopic abundances: Pure and A pplied Chemistry, v. 66, p. $273-276$.

Coplen, T.B., Hopple, J.A ., Bohlke, J.K., Peiser, H.S., Rieder, S.E., Krouse, H.R., Rosman, K.J.R., Ding, T., Vocke, R.D., J r., Revesz, K.M ., L amberty, A., Taylor, P., and DeB ierve, P., 2002, Compilation of minimum and maximum isotope ratios of selected elements in naturally occurring terrestrial materials and reagents: U.S. Geological Survey Water-Resources Investigations Report 01-4222, 98 p.

Coplen, T.B., Wildman, J.D., and Chen, J., 1991, Improvements in the gaseous hydrogen-water equilibrium technique for hydrogen isotope analysis: A nalytical Chemistry, v. 63, p. 910-912.

Densmore, J.N., Fram, M .S., and B elitz, K enneth, 2009, Ground-water quality data in the 0 wens and Indian Wells Valleys study unit, 2006-Results from the California GA M A Program: U.S. Geological Survey Data Series 427, $86 \mathrm{p}$.

Donahue, D.J., Linick, T.W., and J ull, A.J .T., 1990, Isotoperatio and background corrections for accel erator mass spectrometry radiocarbon measurements: Radiocarbon, v. 32 , book 2, p. 135-142.

Dwyer, G.S., and Vengosh, A., 2008, Alternative filament loading solution for accurate analysis of boron isotopes by negative thermal ionization mass spectrometry: Eos, Transactions, A merican Geophysical U nion, v. 89, no. 53, abstract H51C-0824.

Eaton, G.F., Hudson, G.B ., and M oran, J .E., 2004, Tritiumhelium-3 age-dating of groundwater in the Livermore Valley of California: A merican Chemical Society A CS Symposium Series, v. 868, p. 235-245. 
Epstein, Samuel, and M ayeda, T.K., 1953, Variation of 0-18 content of water from natural sources: Geochimica et Cosmochimica A cta, v. 4, p. 213-224.

Faires, L.M ., 1993, M ethods of analysis by the U.S. Geological Survey National Water Q uality L aboratoryDetermination of metals in water by inductively coupled plasma-mass spectrometry: U.S. G eological Survey Open-File Report 92-634, 28 p.

Farrar, J.W., and L ong, H.K., 1997, Report on the U.S. Geological Survey's evaluation program for standard reference samples distributed in September 1996- T-143 (trace constituents), T-145 (trace constituents), M -140 (major constituents), N-51 (nutrient constituents), P-27 (low ionic strength constituents), and Hg-23 (mercury): U.S. Geological Survey Open-File Report 97-20, 145 p.

Faure, Gunter, and M ensing, T.M ., 2005, I sotopes- Principles and applications ( $3 d$ ed.): Hoboken, N ew Jersey, J ohn Wiley \& Sons, Inc., 897 p.

Ferrari, M .J ., Fram, M .S., and B elitz, K enneth, 2008, Ground-water quality in the Central Sierra study unit, California, 2006-R esults from the California GA M A Program: U.S. Geological Survey Data Series 335, 60 p.

Firestone, R.B., Shirley, V.S., B aglin, C.M ., Chu, S.Y.F., and Zipkin, J., 1996, Table of isotopes (8th ed.): N ew York, J ohn Wiley \& Sons, 3168 p., accessed N ovember 16, 2010, at http://ie.lbl.gov/toipdf/toi20.pdf.

Fishman, M.J., 1993, M ethods of analysis by the U.S. Geological Survey National Water Q uality L aboratoryDetermination of inorganic and organic constituents in water and fluvial sediments: U.S. Geological Survey Open-File Report 93-125, 217 p.

Fishman, M .J ., and Friedman, L.C., 1989, M ethods for determination of inorganic substances in water and fluvial sediments: U.S. Geological Survey Techniques of Water-Resources Investigations, book 5, chap. A 1, 545 p.

Fram, M .S., and B elitz, K enneth, 2007, Groundwater quality data in the Southern Sierra Study U nit, 2006- Results from the California GA M A Program: U.S. Geological Survey Data Series 258, $78 \mathrm{p}$.

Fram, M.S., M unday, C.M ., and B elitz, K enneth, 2009, Ground-water quality data for the Tahoe-M artis study unit, 2007-Results from the California GA M A Program: U.S. Geological Survey Data Series 432, $80 \mathrm{p}$.

Fram, M .S., and B elitz, K enneth, 2011, Occurrence and concentrations of pharmaceutical compounds in groundwater used for public drinking-water supply in California: Science of the Total Environment, v. 409, no. 18, p. 3409-3417. (A Iso available at http://www. sciencedirect. com/science/article/pii/S0048969711005778.)
Furlong, E.T., Werner, S.L., A nderson, B.D., and Cahill, J.D., 2008, Determination of human-health pharmaceuticals in filtered water by chemically modified styrene-divinyl benzene resin-based solid-phase extraction and high-performance liquid chromatography/mass spectrometry: U.S. Geological Survey Techniques and M ethods, book 5, sec. B, chap. B 5, 56 p.

Gagnon, A.R., and J ones, G .A ., 1993, A M S-graphite target production methods at the Woods Hole Oceanographic Institution during 1986-1991: Radiocarbon, v. 35, book 2, p. 301-310.

Garbarino, J.R., 1999, M ethods of analysis by the U.S. Geological Survey National Water Quality LaboratoryDetermination of dissolved arsenic, boron, lithium, selenium, strontium, thallium, and vanadium using inductively coupled plasma-mass spectrometry: U.S. Geological Survey Open-File Report 99-093, 31 p.

Garbarino, J.R., K anagy, J.R., and Cree, M .E., 2006, Determination of el ements in natural-water, biota, sediment, and soil samples using collision/reaction cell inductively coupled plasma-mass spectrometry: U.S. Geological Survey Techniques and M ethods, book 5, chap. B 1, 88 p.

Gilliom, R.J ., Barbash, J.E., Crawford, C.G., Hamilton, P.A., M artin, J.D., Nakagaki, N ., N owell, L.H., Scott, J.C., Stackelberg, P.E., Thelin, G.P., and Wolock, D.M., 2006 , The quality of our nation's waters- Pesticides in the nation's streams and groundwater, 1992-2001: U.S. Geological Survey Circular 1291, 172 p.

Goldrath, D.A., Wright, M .T., and B elitz, K enneth, 2010, Groundwater-quality data in the Colorado River study unit, 2007-Results from the California GA M A Program: U.S. Geological Survey Data Series 474, 66 p.

Gran, G., 1952, Determination of the equivalence point in potentiometric titration, Part II: A nalyst, v. 77, p. 661.

Grob, R.L., ed., 1995, M odern practice of gas chromatography (3d ed.): N ew Y ork, J ohn Wiley \& Sons, 888 p.

Hahn, G.J ., and M eeker, W.Q., 1991, Statistical intervals-A guide for practitioners: N ew York, John Wiley \& Sons, $392 p$.

Hem, J.D., 1985, Study and interpretation of the chemical characteristics of natural water: U.S. Geological Survey Water-Supply Paper 2254, 263 p., 3 pls.

Hoaglin, D.C., 1983, Letter values-A set of selected order statistics, in Hoaglin, D.C., M osteller, F., and Tukey, J.W., eds., Understanding robust and exploratory data analysis: N ew York, John Wiley \& Sons, p. 33-54. 
K enny, J.F., B arber, N.L., Hutson, S.S., Linsey, K .S., Lovelace, J.K., and M aupin, M .A., 2009, Estimated use of water in the U nited States in 2005: U.S. Geological Survey Circular 1344, 52 p.

Kolpin, D.W., Furlong, E.T., M eyer, M .T., Thurman, E.M ., Zaugg, S.D., B arber, L.B., and B uxton, H.T., 2002, Pharmaceuticals, hormones and other organic wastewater contaminants in U.S. streams, 1999-2000: Environmental Science \& Technology, v. 36, no. 6, p. 1202-1211.

K oterba, M .T., Wilde, F.D., and L apham, W.W., 1995, Groundwater data-collection protocols and procedures for the N ational Water-Q ual ity A ssessment ProgramCollection and documentation of water-quality samples and related data: U.S. Geological Survey O pen-File Report 95-399, 113 p.

K reiger, H.L., and W hittaker, E.L., 1980, Prescribed procedures for measurement of radioactivity in drinking water: U.S. Environmental Protection A gency EPA -600-480-032, 142 p. (A Iso available as PB 80-224744 at http:/l www.ntis.gov.)

K ulongoski, J.T., and B elitz, K enneth, 2004, Groundwater A mbient M onitoring and A ssessment Program: U.S. Geological Survey Fact Sheet 2004-3088, 2 p.

K ul ongoski, J.T., B elitz, K enneth, and Dawson, B.J., 2006, Groundwater quality data in the North San Francisco Bay Hydrogeologic provinces, California, 2004: Results from the California Groundwater A mbient M onitoring and A ssessment (GA M A) Program: U.S. Geological Survey Data Series 167, $100 \mathrm{p}$.

Land, M .T., and B elitz, K enneth, 2008, Groundwater quality data in the San Fernando-San Gabriel study unit, 2005-Results from the California GA M A Program: U.S. Geological Survey Data Series 356, 84 p.

L andon, M .K., B elitz, K enneth, Jurgens, B.C., K ulongoski, J.T., and J ohnson, T.D., 2010, Status and understanding of groundwater qual ity in the Central-E astside San J oaquin Basin, 2006: California G A M A Priority Basin Project: U.S. Geological Survey Scientific Investigations Report 2009-5266, $97 \mathrm{p}$.

Lane, S.L., Flanagan, Sarah, and Wilde, F.D., 2003, Selection of equipment for water sampling (ver. 2.0): U.S. Geological Survey Techniques of Water-R esources Investigations, book 9, chap. A 2, accessed September 17, 2010, at http:// pubs.water.usgs.gov/twrigA 2/.

Lewis, M .E., 2006, Dissolved oxygen (ver. 2.1): U.S. Geological Survey Techniques of Water-Resources Investigations, book 9, chap. A 6.2, accessed A ugust 18, 2009, at http://pubs.water.usgs.gov/twri9A 6.21.
Lindley, C.E., Stewart, J.T., and Sandstrom, M.W., 1996, Determination of low concentrations of acetochlor in water by automated solid-phase extraction and gas chromatography with mass selective detection: J ournal of A O A C International, v. 79, no. 4, p. 962-966.

M adsen, J.E., Sandstrom, M .W., and Zaugg, S.D., 2003, M ethods of analysis by the U.S. Geological Survey National Water Quality Laboratory-A method supplement for the determination of fipronil and degradates in water by gas chromatography/mass spectrometry: U.S. Geological Survey O pen-File Report 02-462, 11 p.

M aloney, T.J ., ed., 2005, Q uality management system, U.S. Geological Survey N ational Water Quality Laboratory: U.S. Geological Survey O pen-File Report 2005-1263, accessed N ovember 8, 2010, at http://pubs.usgs.gov/of/2005/1263/.

M athany, T.M ., and B elitz, K enneth, 2009, Ground-water quality data in the M ojave study unit, 2008- Results from the California GA M A Program: U.S. Geological Survey Data Series 440, $80 \mathrm{p}$.

M athany, T.M ., B urton, C.A ., L and, M.T., and B elitz, K enneth, 2010, Groundwater-quality data in the Southern Coast Range-Coastal study unit, 2008-Results from the California GA M A Program: U.S. Geological Survey Data Series $504,106 \mathrm{p}$.

M cCurdy, D.E., Garbarino, J .R., and M ullin, A.H ., 2008, Interpreting and reporting radiological water-quality data: U.S. Geological Survey Techniques and M ethods, book 5, chap. B6, $33 \mathrm{p}$.

M CL ain, B ., 1993, M ethods of analysis by the U.S. Geological Survey N ational Water Quality L aboratory-D etermination of chromium in water by graphite furnace atomic absorption spectrophotometry: U.S. Geological Survey Open-File Report 93-449, $16 \mathrm{p}$.

M cNichol, A.P., Gagnon, A.R., J ones, G.A., and Osborne, E.A., 1992, Illumination of a black box-A nalysis of gas composition during graphite target preparation, in L ong, A ., and K ra, R.S., eds., Proceedings of the 14th International ${ }^{14} \mathrm{C}$ Conference: Radiocarbon, v. 34, book 3, p. 321-329.

M cNichol, A .P., J ones, G.A ., Hutton, D.L., and Gagnon, A.R., 1994, The rapid preparation of seawater $\sum \mathrm{CO}_{2}$ for radiocarbon analysis at the $\mathrm{N}$ ational $\mathrm{O}$ cean Sciences A M S Facility: Radiocarbon, v. 36, book 2, p. 237-246.

M endez, G.O., and Christensen, A.H., 1997, Regional water table (1996) and water-level changes in the M ojave River, M orongo, and Fort Irwin ground-water basins, San B ernardino County, California: U.S. Geological Survey Water-R esources Investigations R eport 97-4160, 34 p., accessed November 30, 2010, at http://pubs.er.usgs.gov/ usgspubs/wri/wri974160. 
M oran, J .E., Hudson, G.B., Eaton, G.F., and Leif, R., 2002, A contamination vulnerability assessment for the Livermore-A mador and Niles Cone Groundwater B asins: L aw rence Livermore $N$ ational L aboratory internal report UCRL -A R-148831, 25 p.

M ueller, D.K., and Titus, C.J ., 2005, Quality of nutrient data from streams and ground water sampled during water years 1992-2001: U.S. Geological Survey Scientific Investigations Report 2005-5106, 27 p.

Olsen, L.D., Fram, M.S., and B elitz, K enneth, 2010, Review of trace-element field-blank data collected for the California Groundwater A mbient M onitoring and A ssessment (GA M A) Program, M ay 2004-J anuary 2008: U.S. Geological Survey Scientific Investigations Report 2009-5220, 47 p.

Patton, C.J., and K ryskalla, J.R., 2003, M ethods of analysis by the U.S. Geological Survey National Water Quality Laboratory-Evaluation of al kaline persulfate digestion as an alternative to $\mathrm{K} \mathrm{jel}$ dahl digestion for determination of total and dissolved nitrogen and phosphorous in water: U.S. G eological Survey Water-Resources Investigations Report 03-4174, $33 \mathrm{p}$.

Pirkey, K.D., and Glodt, S.R., 1998, Quality control at the U.S. G eological Survey National Water Quality L aboratory: U.S. Geological Survey Fact Sheet 026-98, 4 p., accessed N ovember 12, 2010, at http://pubs.er.usgs.gov/usgspubs/fs/ fs02698.

Plomley, J.B., K oester, C.J ., and M arch, R.E., 1994, Determination of NDM A in complex environmental matrices by quadrupole ion storage tandem mass spectrometry enhanced by unidirectional ion ejection: A nalytical Chemistry, v. 66, no. 24, p. 4437-4443.

PRISM Climate Group, Oregon State U niversity, 2010, United States average annual precipitation, maximum and minimum temperature, 1971-2009, accessed J anuary 14, 2011, at http://prism.oregonstate.edu/.

Radtke, D.B., Davis, J.V., and Wilde, F.D., 2005, Specific electrical conductance (ver. 1.2): U.S. G eological Survey Techniques of Water-R esources Investigations, book 9 , chap. A 6.3, accessed N ovember 17, 2010, at http://pubs. water.usgs.gov/twri9A 6.3/.

Sandstrom, M.W., Stroppel, M .E., Foreman, W.T., and Schroeder, M .P., 2001, M ethods of analysis by the U.S. Geological Survey National Water Q uality L aboratoryDetermination of moderate-use pesticides and selected degradates in water by $\mathrm{C}-18$ solid-phase extraction and gas chromatography/mass spectrometry: U.S. Geological Survey Water-R esources Investigations Report 01-4098, $70 \mathrm{p}$.
Schmitt, S.J., M ilby Dawson, B.J., and B elitz, K enneth, 2009, Groundwater-quality data in the A ntelope Valley study unit, 2008-Results from the California GA M A Program: U.S. Geological Survey Data Series 479, $79 \mathrm{p}$.

Schneider, R.J ., J ones, G.A ., M cNichol, A .P., von Reden, K.F., Elder, K.A., Huang, K., and Kessel, E.D., 1994, Methods for data screening, flagging, and error analysis at the N ational O cean Sciences A M S F acility: N uclear Instruments and M ethods in Physics Research, book 92, p. 172-175.

Scott, J.C., 1990, Computerized stratified random site selection approaches for design of a groundwater quality sampling network: U.S. G eological Survey Water-Resources Investigations Report 90-4101, 109 p.

Shel ton, J .L., B urow, K .R ., B elitz, K enneth, Dubrovsky, N.M ., L and, M.T., and Gronberg, J.M ., 2001, Low-level volatile organic compounds in active public supply wells as groundwater tracers in the L os A ngeles physiographic basin, California, 2000: U.S. Geological Survey Water-Resources Investigations Report 01-4188, 29 p.

Soddy, F., 1913, Radioactivity: A nnual Reports on the Progress of Chemistry, v. 10, p. 262-288.

State of California, 2001a, A ssembly Bill N 0. 599, Chapter 522, accessed February 14, 2011, at http://www. swrcb.ca.gov/gama/docs/ab_599_bill_20011005_chaptered. pdf.

State of California, 2001b, Groundwater M onitoring A ct of 2001: C al ifornia Water Code, part 2.76, Sections 1078010782.3, accessed February 14, 2011, at http://www.leginfo. ca.gov/cgi-bin/displaycode? section $=$ wat $\&$ group $=10001$ 11000\&file $=10780-10782.3$.

Thatcher, L .L., J anzer, V.J ., and Edwards, K.W., 1977, $M$ ethods for the determination of radioactive substances in water: U.S. Geological Survey Techniques of Water-Resources Investigations, book 5, chap. A 5, 95 p.

Timme, P.J., 1995, N ational Water Quality Laboratory 1995 services catal og: U.S. Geological Survey Open-File Report 95-352, $120 \mathrm{p}$.

U.S. Department of Commerce, National Climatic Data Center, 2010, National Climatic Data Center, accessed January 13, 2011, at http://www.ncdc.noaa.gov/oa/ncdc. html.

U.S. Environmental Protection A gency, 1989, Semivolatile organic compounds by isotope dilution GSM S (J uly 1989): Washington, D.C., U.S. Environmental Protection A gency, $68 \mathrm{p}$. 
U.S. Environmental Protection A gency, 1994, M ethod 218.6-Determination of dissolved hexavalent chromium in drinking water, groundwater and industrial wastewater effluents by ion chromatography (Revision 3.3, January 2005): Office of Groundwater and Drinking Water, EPA D ocument \# 815-R-05-007, 34 p., accessed October 11, 2010, at http://www.epa.gov/safewater/ methods/pdfs/methods/met331 0.pdf.

U.S. Environmental Protection A gency, 1996, M ethod 7199-D etermination of dissolved hexavalent chromium in drinking water, groundwater and industrial wastewater effluents by ion chromatography: Office of Groundwater and Drinking Water, EPA D ocument \# 846, 10 p., accessed October 11, 2010, at http://www.epa.gov/osw/ hazard/testmethods/sw846/pdfs/7199.pdf.

U.S. Environmental Protection A gency, 1999, N ational primary drinking water regulations, Radon-222: Federal Register, v. 64, no. 211, p. 59, 245-259, and 294.

U.S. Environmental Protection A gency, 2002, Guidelines for establishing procedures for the analysis of pollutants: U.S. Code of Federal Regulations, Title 40, $136 \mathrm{p}$.

U.S. Environmental Protection A gency, 2005, M ethod 331.0Determination of perchlorate in drinking water by liquid chromatography electrospray ionization mass spectrometry (Revision 1.0, January 2005): Office of Groundwater and D rinking Water, EPA D ocument \# 815-R-05-007, 34 p., accessed A ugust 11, 2010, at http://www.epa.gov/safewater/ methods/pdfs/methods/met331 0.pdf.

U.S. Environmental Protection A gency, 2008a, D rinking water contaminants, accessed A ugust 11, 2010, at http://www.epa. gov/safewater/contaminants/index.html.

U.S. Environmental Protection A gency, 2008b, D rinking water health advisories- 2006 drinking water standards and health advisory tables, accessed A ugust 11, 2010, at http:/l www.epa.gov/waterscience/criteria/drinking/.

U.S. Environmental Protection A gency, 2008c, Proposed radon in drinking water rule, accessed $A$ ugust 11, 2010, at http://www.epa.gov/ogwdw/radon/proposal.html.

U.S. Geological Survey, 2006, National Elevation Dataset (NED): U.S. Geological Survey database, accessed February 14, 2011, at http://ned.usgs.gov/.

U.S. Geological Survey, 2009, M ojave Water Studies, accessed N ovember 30, 2010, at http://ca.water.usgs.gov/ mojave/index.html.

U.S. Geological Survey, 2011a, W hat is the Priority Basin Project?: California Water Science Center website, accessed February 14, 2011, at http://ca.water.usgs.gov/gama/.
U.S. Geological Survey, 2011b, Publications: California Water Science Center website, accessed February 14, 2011, at http://ca.water.usgs.gov/gama/includes/GA M A publications.html.

U.S. Geological Survey, [variously dated], National field manual for the collection of water-quality data: U.S. Geological Survey Techniques of Water-Resources Investigations, book 9, chap. A 1-A 9, accessed September 16, 2010, at http://water.usgs.gov/owq/ FieldM anual/.

U.S. Geological Survey B ranch of Quality Systems, 2008, QA DATA summary-December 2008: U.S. Geological Survey B ranch of Quality Systems, accessed A pril 26, 2012, at http://bqs.usgs.gov/ibsp/qadata.shtml.

U.S. Geological Survey B ranch of Quality Systems, 2010, QA DATA summary-February 2010: U.S. Geological Survey B ranch of Quality Systems, accessed A pril 26, 2012 at http://bqs.usgs.gov/ibsp/qadata.shtml.

Vengosh, A ., Chivas, A .R ., and M cCulloch, M .T., 1989, Direct determination of boron and chlorine isotopes in geological materials by negative thermal ionization mass spectrometry: Chemical Geology, v. 79, p. 333-343.

Vogel, J.S., N elson, D.E., and Southon, J.R., 1987, ${ }^{14} \mathrm{C}$ background levels in an accelerator mass spectrometry system: Radiocarbon, v. 29, book 3, p. 323-333.

Water E ducation Foundation, 2006, Where does my water come from?: Sacramento, Calif., Water E ducation Foundation, accessed September 13, 2010, at http://www. water-ed.org/watersources/default.asp.

Weiss, R.F., 1968, Piggyback sampler for dissolved gas studies on sealed water samples: Deep Sea Research, v. 15, p. 721-735.

Western Regional Climate Center, 2010, Western Regional Climate Center, Summary climate data for Southern California, average monthly precipitation data, accessed J anuary 10, 2011, at http://www.wrcc.dri.edu/summary/ Climsmsca.html.

Wilde, F.D., ed., 2004, Cleaning of equipment for water sampling (ver. 2.0): U.S. Geological Survey Techniques of Water-R esources Investigations, book 9, chap. A 3, accessed November 8, 2010, at http://pubs.water.usgs.gov/twri9A 3/.

Wilde, F.D., 2006, Temperature (ver. 2): U.S. Geological Survey Techniques of Water-R esources Investigations, book 9, chap. A 6.1, accessed N ovember 8, 2010, at http:// pubs.water.usgs.gov/twri9A 6.1/.

Wilde, F.D., B usenberg, E., and Radtke, D.B., 2006, pH (ver. 1.3): U.S. G eological Survey Techniques of WaterResources Investigations, book 9, chap. A 6.4, accessed N ovember 8, 2010, at http://pubs.water.usgs.gov/ twri9A 6.4/. 
Wilde, F.D., and Radtke, D.B., 2005, General information and guidelines (ver. 1.2): U.S. Geological Survey Techniques of Water-R esources Investigations, book 9, chap. A 6.0, accessed N ovember 8, 2010, at http://pubs.water.usgs.gov/ twri9A 6.0/.

Wilde, F.D., Radtke, D.B., Gibs, J., and I watsubo, R.T., 1999, Collection of water samples: U.S. G eological Survey Techniques of Water-R esources Investigations, book 9 , chap. A 4, accessed N ovember 8, 2010, at http://pubs.water. usgs.gov/twrigA 4/.

Wilde, F.D., Radtke, D.B., Gibs, J ., and I watsubo, R.T., 2004, Processing of water samples: U.S. Geological Survey Techniques of Water-R esources Investigations, book 9 , chap. A 5, accessed N ovember 8, 2010, at http://pubs.water. usgs.gov/twrigA 5/.
Wright, M .T., B elitz, K enneth, and Burton, C.A ., 2005, California GA M A Program-Groundwater quality in the San D iego drainages hydrologic province, California, 2004: U.S. Geological Survey Data Series 129, 91 p.

Zaugg, S.D., Sandstrom, M .W., Smith, S.G., and Fehlberg, K.M ., 1995, M ethods of analysis by the U.S. G eological Survey National Water Quality L aboratory-Determination of pesticides in water by $\mathrm{C}$-18 solid-phase extraction and capillary-column gas chromatography/mass spectrometry: U.S. Geological Survey Open-File Report 95-181, 60 p.

Zogorski, J.S., Carter, J.M., I vahnenko, T., Lapham, W.W., M oran, M.J ., Rowe, B.L., Squillace, P.J ., and Toccalino, P.L., 2006, Volatile organic compounds in the Nation's ground water and drinking-water supply wells: U.S. Geological Survey Circular 1292, 101 p. 
Table 1. Identification, sampling, and construction information for wells sampled for the Borrego, Central Desert, and Low-Use Basins of the Mojave and Sonoran Deserts (CLUB) Groundwater Ambient Monitoring and Assessment (GAMA) study, California, December 2008 to March 2010.

[Sampling schedule is described in table 2. L and-surface datum (LSD) is a datum plane that is approximately at land surface at each well. The altitude of the LSD is described in feet above the North American Vertical Datum 1988 (NAVD 88). Numbered suffix indicates the order of sample collection within each study area. GAMA well identification number: BV, B orrego study-area grid well; BVU, B orrego study-area understanding well; CD, Central Desert study-area grid well; LUB, Low-U se B asins of the M ojave and Sonoran Deserts study-area grid well; LUBU, Low-U se B asins of the M ojave and Sonoran Deserts studyarea understanding well. Other abbreviations: ft, foot; na, not available]

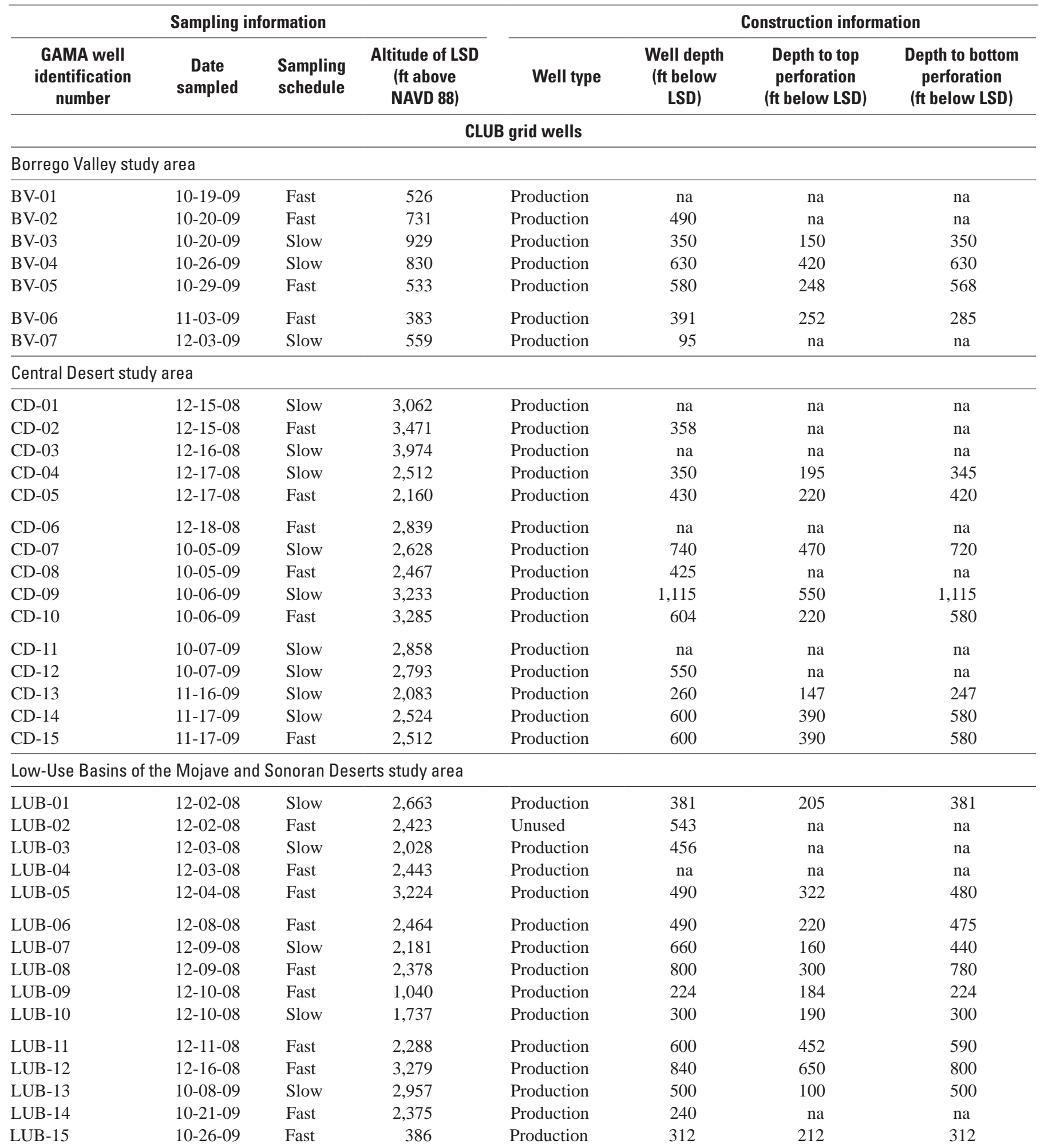


Table 1. Identification, sampling, and construction information for wells sampled for the Borrego, Central Desert, and Low Use Basins of the Mojave and Sonoran Deserts (CLUB) Groundwater Ambient Monitoring and Assessment (GAMA) study, California, December 2008 to March 2010.-Continued

[Sampling schedule is described in table 2. L and-surface datum (LSD) is a datum plane that is approximately at land surface at each well. The altitude of the LSD is described in feet above the North American Vertical Datum 1988 (NAVD 88). Numbered suffix indicates the order of sample collection within each study area. GAMA well identification number: BV, B orrego study-area grid well; BVU, B orrego study-area understanding well; CD, Central Desert study-area grid well; LUB, Low Use Basins of the M ojave and Sonoran Deserts study-area grid well; LUBU, Low U se Basins of the M ojave and Sonoran Deserts study-area understanding well. Other abbreviations: ft, foot; na, not available]

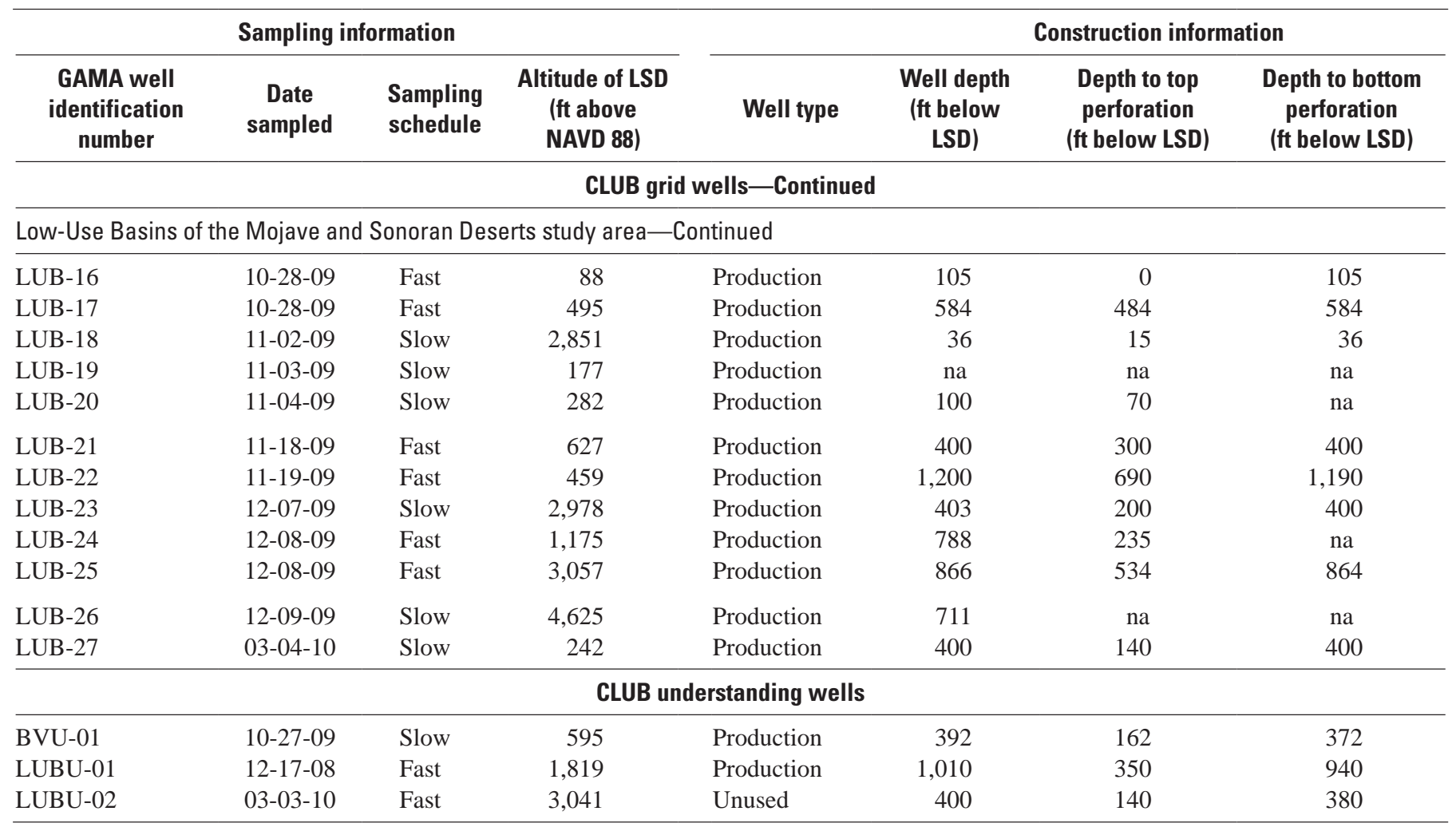


Table 2. Classes of chemical constituents and water-quality indicators collected for the slow and the fast well sampling schedules in the Borrego, Central Desert, and Low-Use Basins of the Mojave and Sonoran Deserts (CLUB) Groundwater Ambient Monitoring and Assessment (GAMA) study, California, December 2008 to March 2010.

\begin{tabular}{|c|c|c|c|c|}
\hline Analyte classes & $\begin{array}{c}\text { Slow } \\
\text { schedule }\end{array}$ & $\begin{array}{c}\text { Fast } \\
\text { schedule }\end{array}$ & $\begin{array}{l}\text { Analyte list } \\
\text { table }\end{array}$ & $\begin{array}{c}\text { Results } \\
\text { table }\end{array}$ \\
\hline \multicolumn{5}{|l|}{ Water-quality indicators } \\
\hline Dissolved oxygen, temperature, $\mathrm{pH}$, and specific conductance & $\mathrm{x}$ & $\mathrm{x}$ & & 4 \\
\hline Field al kalinity, bicarbonate, and carbonate & $x$ & & & 4 \\
\hline \multicolumn{5}{|l|}{ Organic constituents } \\
\hline Volatile organic compounds (V OC) & $\mathrm{x}$ & $\mathrm{x}$ & $3 \mathrm{~A}$ & 5 \\
\hline Pesticides and pesticide degradates & $x$ & $x$ & 3B & 6 \\
\hline Pharmaceutical compounds & $\mathrm{x}$ & & $3 \mathrm{C}$ & none ${ }^{1}$ \\
\hline \multicolumn{5}{|l|}{ Constituents of special interest } \\
\hline Perchlorate & $x$ & $\mathrm{x}$ & 3D & 7 \\
\hline $\mathrm{N}$-nitrosodimethylamine (NDM A) & $x$ & & $3 \mathrm{D}$ & none 2 \\
\hline \multicolumn{5}{|l|}{ Inorganic constituents } \\
\hline Trace el ements & $x$ & $x^{3}$ & $3 E$ & 8 \\
\hline Nutrients & $\mathrm{x}$ & $x^{3}$ & $3 \mathrm{~F}$ & 9 \\
\hline M ajor and minor ions, silica, and total dissolved solids (TDS) & $\mathrm{x}$ & $x^{3}$ & 3G & 10 \\
\hline L aboratory alkalinity, bicarbonate, and carbonate & $\mathrm{x}$ & $\mathrm{x}$ & 3G & 4 \\
\hline Species of inorganic chromium & $x^{4}$ & & $3 \mathrm{H}, 3 \mathrm{I}$ & 11,12 \\
\hline \multicolumn{5}{|l|}{ Stable isotopes } \\
\hline Stable isotopes of hydrogen and oxygen in water & $x$ & $x$ & 3] & 13 \\
\hline Stable isotopes of carbon in dissolved inorganic carbon and carbon-14 abundance & $\mathrm{x}$ & $\mathrm{x}$ & 3] & 13 \\
\hline Stable isotopes of boron in water & $\mathrm{x}$ & & 3] & none ${ }^{5}$ \\
\hline Stable isotopes of strontium in water & $x$ & & 3) & none ${ }^{5}$ \\
\hline \multicolumn{5}{|l|}{ Radioactivity and dissolved noble gases } \\
\hline Tritium & $\mathrm{x}$ & $\mathrm{x}$ & 3] & 13 \\
\hline Radon-222 & $\mathrm{x}$ & & 3] & $14 \mathrm{~A}$ \\
\hline Radium isotopes (radium-226 and radium-228) & $\mathrm{x}$ & & 3] & $14 \mathrm{~B}$ \\
\hline Gross alpha and gross beta radioactivity ( 72 -hour and 30 -day) & $\mathrm{x}$ & & 3] & $14 \mathrm{C}$ \\
\hline Dissolved noble gases, tritium, and helium isotope ratios & $x$ & $x$ & $3 \mathrm{~K}$ & none ${ }^{6}$ \\
\hline
\end{tabular}

${ }^{1}$ Pharmaceutical compounds were not detected at concentrations greater than or equal to method detection limits in the CLUB study unit.

${ }^{2}$ Constituent was not detected in groundwater samples.

${ }^{3}$ Wells sampled on the fast schedule in the L ow-U se B asins of the M ojave and Sonoran Deserts study area included these constituents.

${ }^{4} \mathrm{H}$ exavalent chromium analysis from TestA merica L aboratories, Inc., Irvine, California, was added to the slow sampling schedule starting in 0 ctober 2009.

${ }^{5}$ Results for the stable isotopes of boron and strontium in water analyzed by U.S. G eological Survey National Research Program M etals Isotope Research Laboratory, M enlo Park, California, were not completed in time for inclusion in this report; results will be presented in a subsequent publication.

${ }^{6}$ Results for dissolved noble gases, tritium, and helium isotope ratios analyzed by Lawrence Livermore N ational L aboratory, Livermore, California, were not completed in time for inclusion in this report; results will be presented in a subsequent publication. 

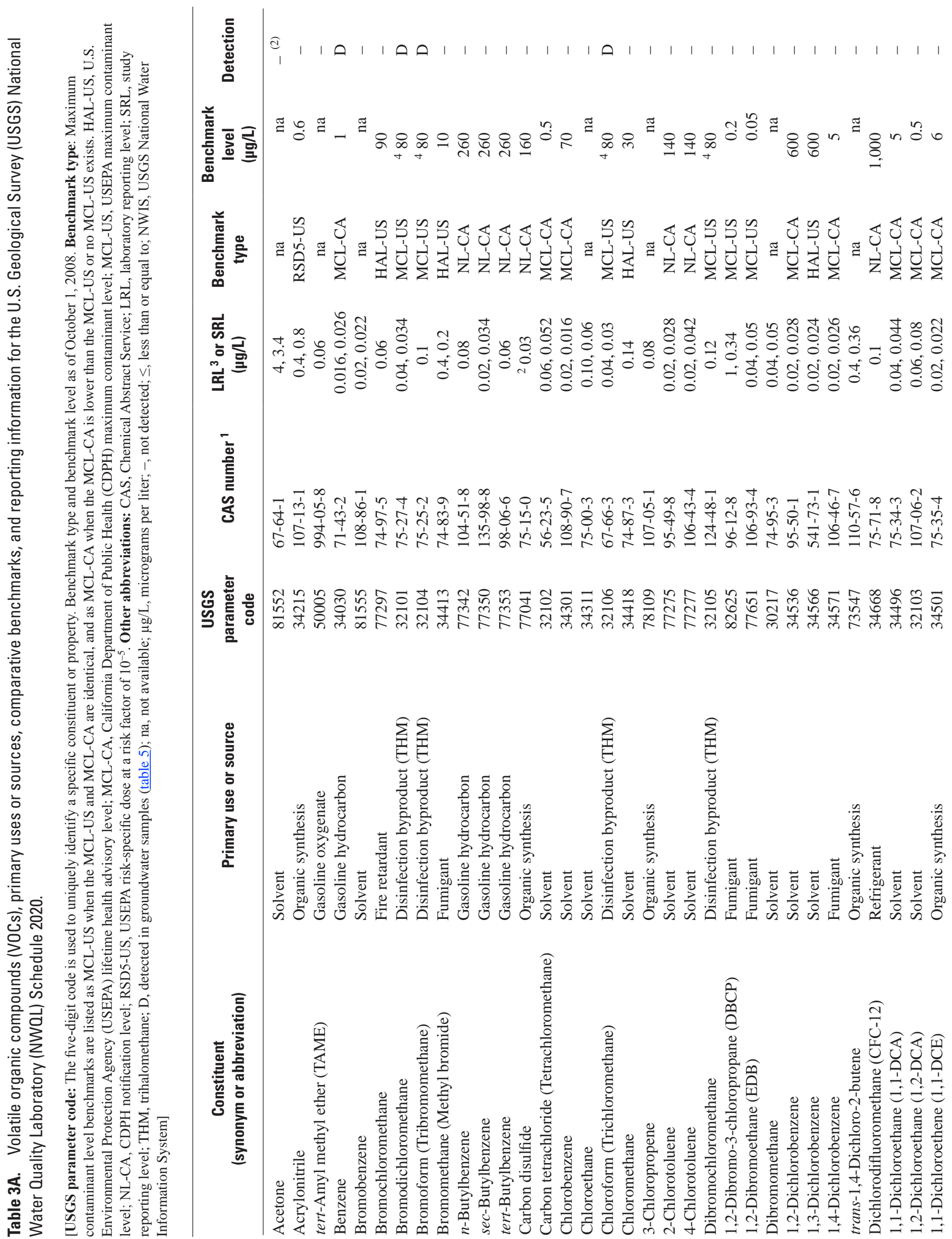


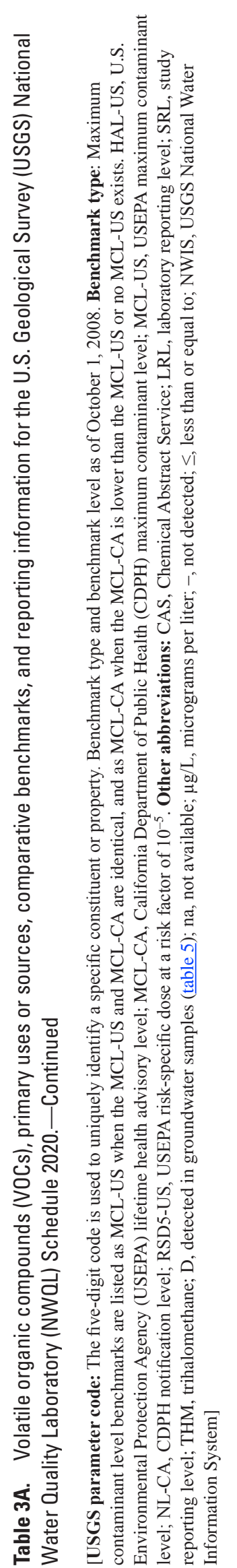

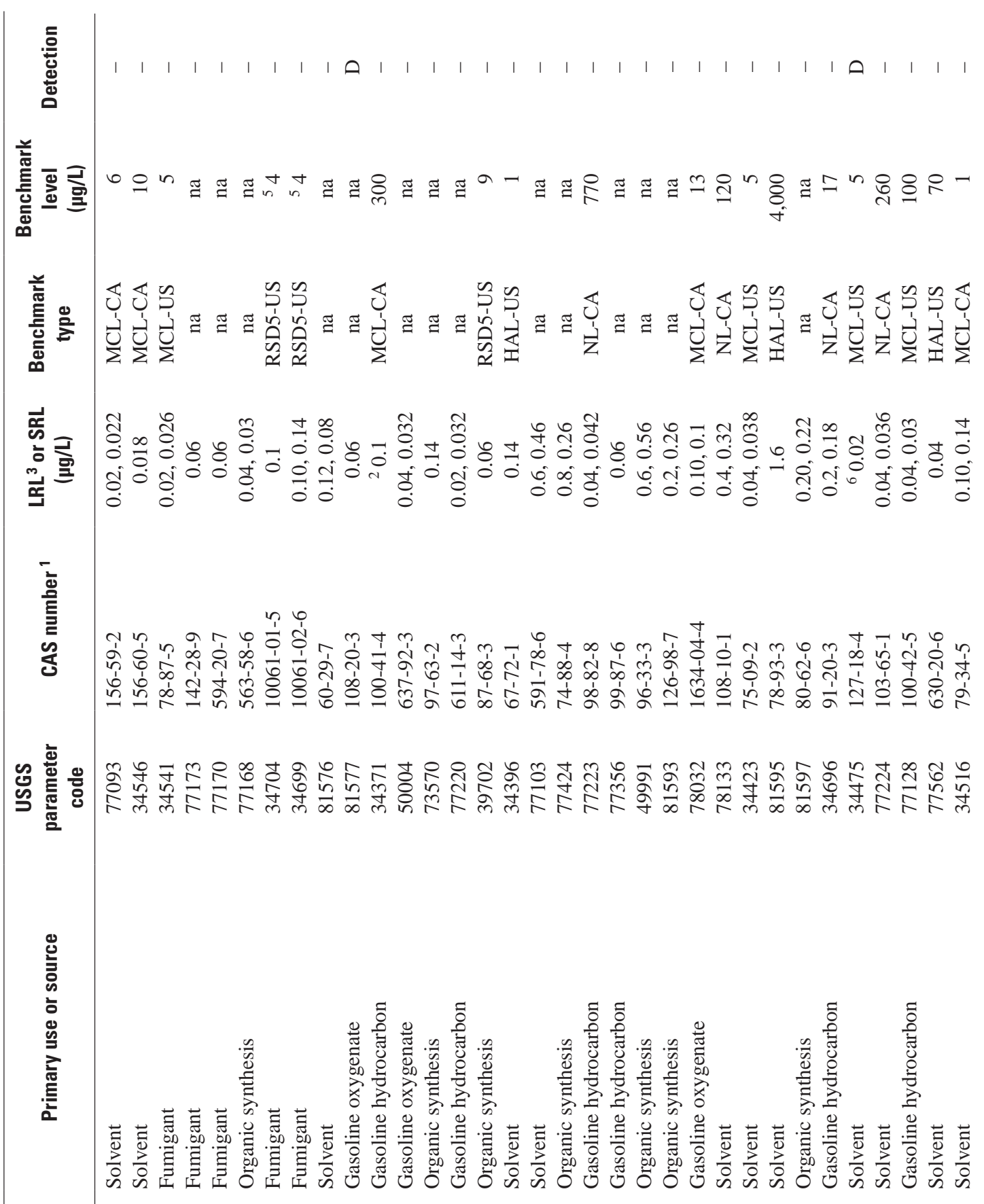

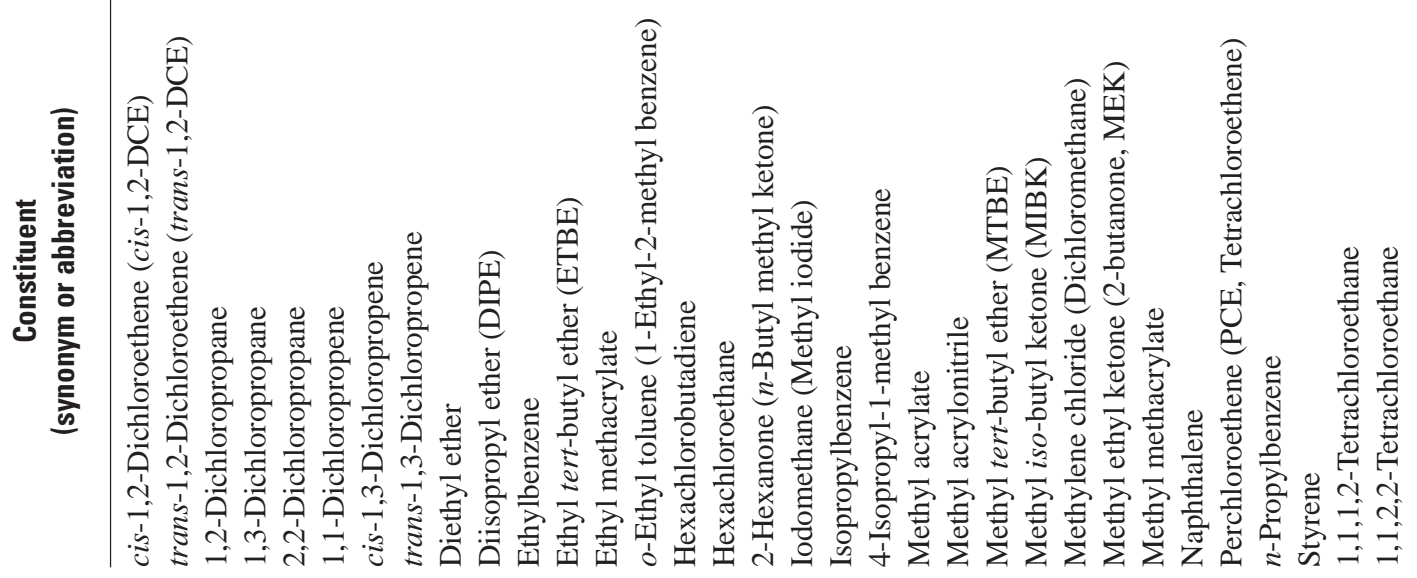



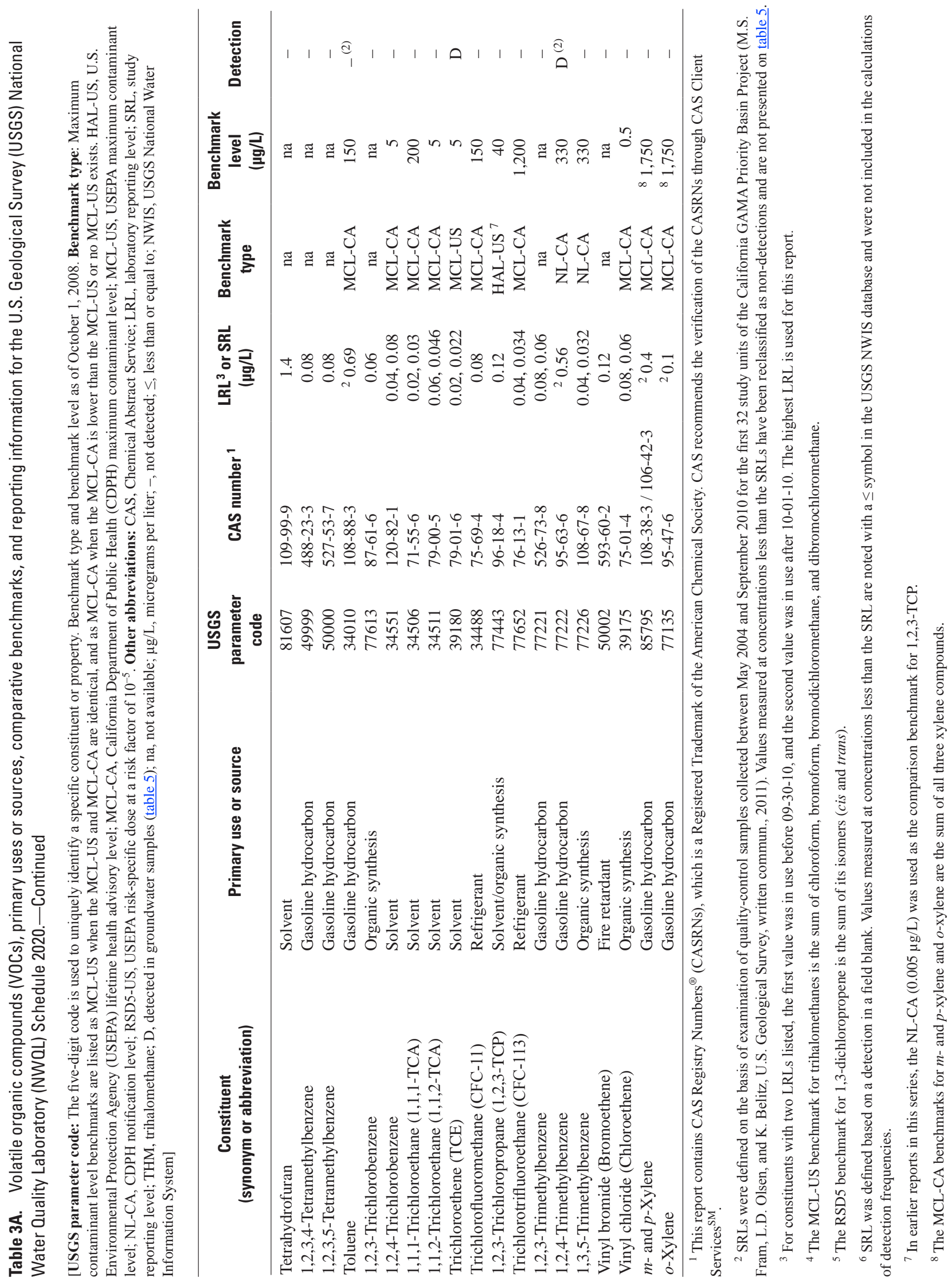
Table 3B. Pesticides and pesticide degradates, primary uses or sources, comparative benchmarks, and reporting information for the U.S. Geological Survey (USGS) National Water Quality Laboratory (NWQL) Schedule 2003.

[The five-digit USGS parameter code is used to uniquely identify a specific constituent or property. Benchmark type and benchmark level as of October 1, 2008. Benchmark type: $M$ aximum contaminant level benchmarks are listed as M CL-US when the M CL-US and M CL-CA are identical, and as M CL-CA when the M CL-CA is lower than the M CL-US or no M CL-US exists. HAL-US, U.S. Environmental Protection A gency (USEPA) lifetime health advisory level; M CL-CA, California Department of Public Health maximum contaminant level; MCL-US, USEPA maximum contaminant level; RSD5-US, USEPA risk-specific dose at a risk factor of $10^{-5}$. Other abbreviations: CA S, Chemical A bstract Service; LRL, laboratory reporting level; D, detected in groundwater samples (table 6); na, not available; $\mu \mathrm{g} / \mathrm{L}$, micrograms per liter; - , not detected]

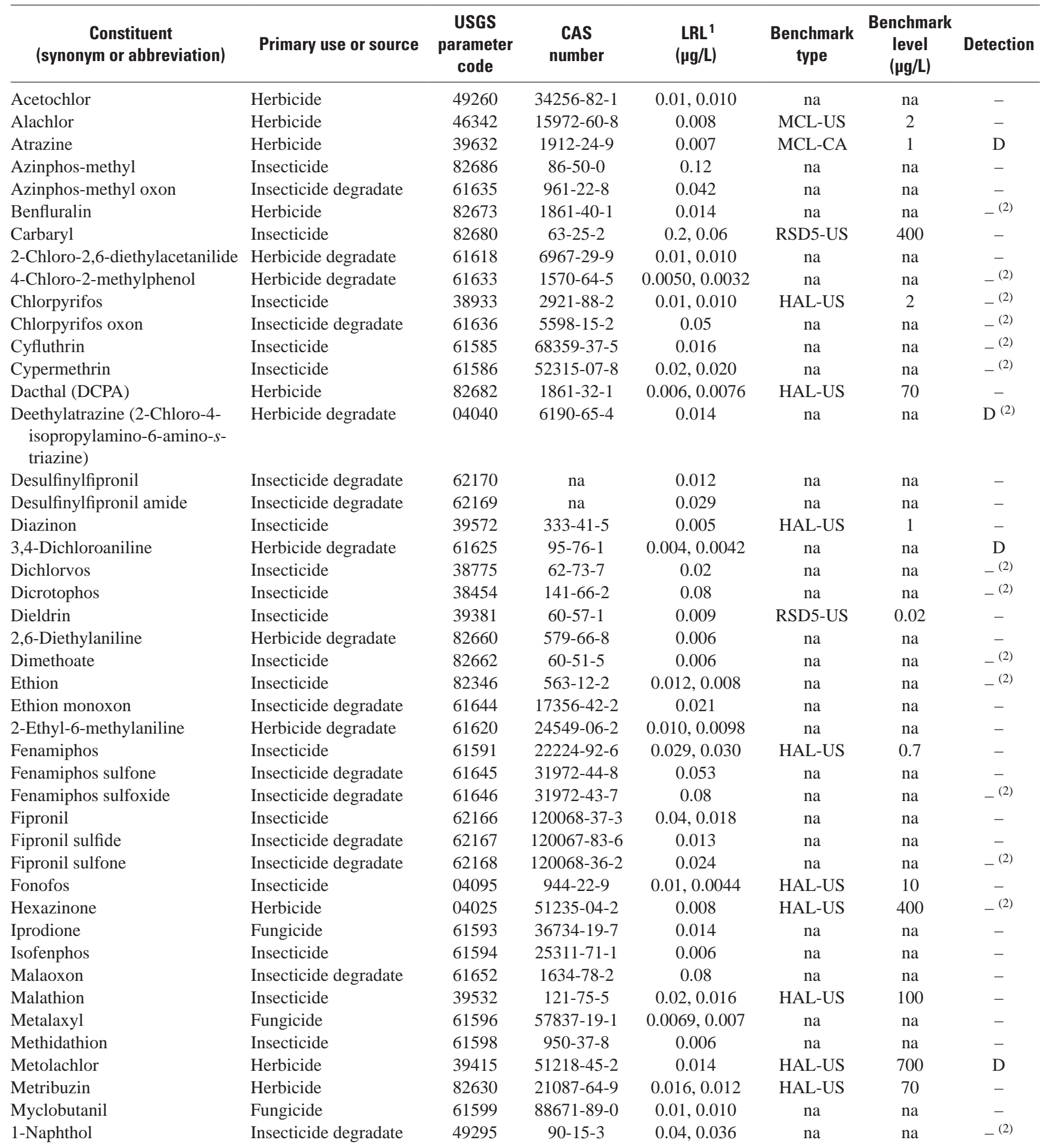


Table 3B. Pesticides and pesticide degradates, primary uses or sources, comparative benchmarks, and reporting information for the U.S. Geological Survey (USGS) National Water Quality Laboratory (NWOL) Schedule 2003.-Continued

[The five-digit USGS parameter code is used to uniquely identify a specific constituent or property. Benchmark type and benchmark level as of October $1,2008$. Benchmark type: M aximum contaminant level benchmarks are listed as M CL-US when the M CL-US and M CL-CA are identical, and as M CL-CA when the MCL-CA is lower than the M CL-US or no M CL-US exists. HAL-US, U.S. Environmental Protection A gency (USEPA) lifetime health advisory level; M CL-CA, California Department of Public Health maximum contaminant level; MCL-US, USEPA maximum contaminant level; RSD5-US, USEPA risk-specific dose at a risk factor of $10^{-5}$. Other abbreviations: CAS, Chemical A bstract Service; LRL, laboratory reporting level; D, detected in groundwater samples (table 6); na, not available; $\mu \mathrm{g} / \mathrm{L}$, micrograms per liter; - , not detected]

\begin{tabular}{|c|c|c|c|c|c|c|c|}
\hline $\begin{array}{c}\text { Constituent } \\
\text { (synonym or abbreviation) }\end{array}$ & Primary use or source & $\begin{array}{c}\text { USGS } \\
\text { parameter } \\
\text { code }\end{array}$ & $\begin{array}{c}\text { CAS } \\
\text { number }\end{array}$ & $\begin{array}{r}\mathrm{LRL}^{1} \\
(\mu \mathrm{g} / \mathrm{L})\end{array}$ & $\begin{array}{c}\text { Benchmark } \\
\text { type }\end{array}$ & $\begin{array}{c}\text { Benchmark } \\
\text { level } \\
\text { ( } \mu \mathrm{g} / \mathrm{L})\end{array}$ & Detection \\
\hline Parathion-methyl & Insecticide & 82667 & $298-00-0$ & 0.008 & HAL-US & 1 & - (2) \\
\hline Pendimethalin & Herbicide & 82683 & $40487-42-1$ & 0.012 & na & na & - \\
\hline cis-Permethrin & Insecticide & 82687 & $54774-45-7$ & 0.014 & na & na & - (2) \\
\hline Phosmet & Insecticide & 61601 & $732-11-6$ & $0.2,0.034$ & na & na & - (2) \\
\hline Phosmet oxon & Insecticide degradate & 61668 & $3735-33-9$ & 0.0511 & na & na & - (2) \\
\hline Prometon & Herbicide & 04037 & $1610-18-0$ & 0.012 & HAL-US & 100 & - \\
\hline Prometryn & Herbicide & 04036 & $7287-19-6$ & $0.0059,0.006$ & na & na & - \\
\hline Pronamide (Propyzamide) & Herbicide & 82676 & $23950-58-5$ & $0.004,0.0036$ & RSD5-US & 20 & - \\
\hline Terbuthylazine & Herbicide & 04022 & $5915-41-3$ & 0.006 & na & na & - \\
\hline Tribufos & Defoliant & 61610 & $78-48-8$ & $0.035,0.018$ & na & na & $-(2)$ \\
\hline Trifluralin & Herbicide & 82661 & $1582-09-8$ & $0.012,0.018$ & HAL-US & 10 & - (2) \\
\hline
\end{tabular}

\footnotetext{
${ }^{1}$ For constituents with two LRLs listed, the first value was in use before 09-30-10, and the second value was in use after 10-01-10. The highest LRL is used for this report.

${ }^{2}$ The median matrix-spike recovery was less than 70 percent. Low recoveries may indicate that the compound might not have been detected in some samples if it was present at very low concentrations.

${ }^{3}$ The median matrix-spike recovery was greater than 130 percent. High recoveries may indicate that reported values could be greater than what is detected in the sample.
} 
Table 3C. Pharmaceutical compounds, primary uses or sources, comparative benchmarks, and reporting information for the U.S. Geological Survey (USGS) National Water Quality Laboratory (NWOL) Schedule 2080.

[The five-digit USGS parameter code is used to uniquely identify a specific constituent or property. Abbreviations: CA S, Chemical A bstract Service; SRL, study reporting level; na, not available; $\mu \mathrm{g} / \mathrm{L}$, micrograms per liter]

\begin{tabular}{|c|c|c|c|c|c|c|c|}
\hline Constituent & Primary use or source & $\begin{array}{c}\text { USGS } \\
\text { parameter } \\
\text { code }\end{array}$ & $\begin{array}{c}\text { CAS } \\
\text { number }\end{array}$ & $\begin{array}{c}S^{S R L^{1}} \\
(\mu g / L)\end{array}$ & $\begin{array}{c}\text { Benchmark } \\
\text { type }\end{array}$ & $\begin{array}{c}\text { Benchmark } \\
\text { level }\end{array}$ & Detection \\
\hline A Ibuterol & B ronchodilator & 62020 & 18559-94-9 & 0.04 & na & na & - \\
\hline Caffeine & Stimulant & 50305 & $58-08-2$ & 0.10 & na & na & - \\
\hline Carbamazapine & A nticonvulsant; mood stabilizer & 62793 & $298-46-4$ & 0.03 & na & na & - \\
\hline Dehydronifedipine & Antianginal metabolite & 62004 & $67035-22-7$ & 0.04 & na & na & - \\
\hline Diltiazem & A ntianginal; antihypertensive & 62008 & 42399-41-7 & 0.04 & na & na & - \\
\hline 1,7-D imethylxanthine & Caffeine metabolite & 62030 & $611-59-6$ & 0.06 & na & na & - \\
\hline Diphenhydramine & A ntihistamine & 62796 & $147-25-0$ & 0.02 & na & na & - \\
\hline Sulfamethoxazole & A ntibacterial & 62021 & $723-46-6$ & 0.08 & na & na & - \\
\hline
\end{tabular}

${ }^{1}$ The California Groundwater A mbient M onitoring and A ssessment (GA M A) Program uses more conservative reporting limits for the pharmaceutical compounds than are used by the USGS National Water Q uality L aboratory (NW QL) (Fram and B elitz, 2011). The SRL corresponds to the highest long-term method detection limit (LT-M DL) or interim method detection limit (I-M DL) used by the NW QL during the period GA M A samples were analyzed (M ay 2004 through J une 2010). Results reported by the NW Q L with concentrations less than the SRL s are reported as non-detections by GA M A . Data are stored in the USGS National Water Information System (NWIS) database as reported by GA M A : results initially reported as detections with concentrations below the SRL $s$ or as non-detections less than LRLs have been recoded as non-detections less than SRLs. Results for pharmaceutical compounds in groundwater samples from the GA M A B orrego Valley, Central Desert, and Low-U se B asins of the M ojave and Sonoran Deserts (CLU B) study unit are presented in Fram and B elitz (2011). 
Table 3D. Constituents of special interest, primary uses or sources, comparative benchmarks, and reporting information for Weck Laboratories, Inc., analyses.

[The five-digit USGS parameter code is used to uniquely identify a specific constituent or property. Minimum reporting level, benchmark type, and benchmark level as of October 1, 2008. Benchmark type: M aximum contaminant level benchmarks are listed as M CL-US when the M CL-US and M CL-CA are identical, and as M CL-CA when the M CL-CA is lower than the M CL-US or no M CL-US exists. M CL-CA, California D epartment of Public Health (CDPH) maximum contaminant level; NL-CA, CDPH notification level. Other abbreviations: CAS, Chemical A bstract Service; M RL, minimum reporting level; D, detected in groundwater samples (table 7); $\mu \mathrm{g} / \mathrm{L}$, micrograms per liter; -, not detected]

\begin{tabular}{|c|c|c|c|c|c|c|c|}
\hline $\begin{array}{l}\text { Constituent } \\
\text { (synonym or } \\
\text { abbreviation) }\end{array}$ & Primary use or source & $\begin{array}{c}\text { USGS } \\
\text { parameter } \\
\text { code }\end{array}$ & $\begin{array}{c}\text { CAS } \\
\text { number }\end{array}$ & $\begin{array}{c}\text { MRL } \\
(\mu g / L)\end{array}$ & $\begin{array}{c}\text { Benchmark } \\
\text { type }\end{array}$ & $\begin{array}{c}\text { Benchmark } \\
\text { level }\end{array}$ & Detection \\
\hline $\begin{array}{l}\mathrm{N} \text {-nitrosodimethylamine } \\
\text { (NDMA) }\end{array}$ & Disinfection byproduct & 34438 & $62-75-9$ & 0.0020 & $\mathrm{NL}-\mathrm{CA}$ & 0.010 & - \\
\hline
\end{tabular}


Table 3E. Trace elements, comparative benchmarks, and reporting information for the U.S. Geological Survey (USGS) National Water Quality Laboratory (NWOL) Schedule 1948.

[The five-digit USGS parameter code is used to uniquely identify a specific constituent or property. Benchmark type and benchmark level as of October 1, 2008. Benchmark type: M aximum contaminant level benchmarks are listed as M CL-US when the MCL-US and MCL-CA are identical, and as MCL-CA when the MCL-CA is lower than the MCL-US or no M CL-US exists. AL-US, U.S. Environmental Protection A gency (USEPA) action level; HAL-US, USEPA lifetime health advisory level; M CL-CA, California Department of Public Health (CDPH) maximum contaminant level; M CL-US, USEPA maximum contaminant level; NL-CA, CDPH notification level; SMCL-CA, CDPH secondary maximum contaminant level. Other abbreviations: CAS, Chemical A bstract Service; LRL, laboratory reporting level; SRL, study reporting level; $D$, detected in groundwater samples (table 8); na, not available; $\mu \mathrm{g} / \mathrm{L}$, micrograms per liter; $\leq$, less than or equal to; NWIS, USGS National Water Information System; N W Q L, USGS N ational Water Q uality Laboratory; B QS, USGS B ranch of Quality Systems]

\begin{tabular}{|c|c|c|c|c|c|c|}
\hline Constituent & $\begin{array}{c}\text { USGS } \\
\text { parameter } \\
\text { code }\end{array}$ & $\begin{array}{c}\text { CAS } \\
\text { number }\end{array}$ & $\begin{array}{c}\text { LRL }^{1} \text { or SRL } \\
(\mu \mathrm{g} / \mathrm{L})\end{array}$ & $\begin{array}{c}\text { Benchmark } \\
\text { type }\end{array}$ & $\begin{array}{c}\text { Benchmark } \\
\text { level }\end{array}$ & Detection \\
\hline Aluminum & 01106 & $7429-90-5$ & ${ }^{2} 1.6$ & MCL-CA & 1,000 & $D$ \\
\hline A ntimony & 01095 & $7440-36-0$ & $0.04,0.054$ & MCL-US & 6 & $D$ \\
\hline A rsenic & 01000 & $7440-38-2$ & $0.06,0.044$ & MCL-US & 10 & $D$ \\
\hline B arium & 01005 & $7440-39-3$ & 20.36 & $M C L-C A$ & 1,000 & $D$ \\
\hline B eryllium & 01010 & $7440-41-7$ & $0.02,0.012$ & MCL-US & 4 & $D$ \\
\hline Boron & 01020 & $7440-42-8$ & $4,2.8$ & NL-CA & 1,000 & $D$ \\
\hline Cadmium & 01025 & $7440-43-9$ & 0.02 & MCL-US & 5 & $D$ \\
\hline Chromium & 01030 & $7440-47-3$ & 20.42 & $M C L-C A$ & 50 & $D$ \\
\hline Cobalt & 01035 & $7440-48-4$ & ${ }^{3} 0.18$ & na & na & $D$ \\
\hline Copper & 01040 & $7440-50-8$ & ${ }^{2} 1.7$ & AL-US & 1,300 & $D$ \\
\hline Iron & 01046 & $7439-89-6$ & 26 & SM CL-CA & 300 & $D$ \\
\hline Lead & 01049 & 7439-92-1 & ${ }^{2} 0.65$ & AL-US & 15 & $D$ \\
\hline Lithium & 01130 & 7439-93-2 & $1,0.44$ & na & na & $D$ \\
\hline M anganese & 01056 & $7439-96-5$ & ${ }^{2} 0.2$ & SM CL-CA & 50 & $D$ \\
\hline M olybdenum & 01060 & 7439-98-7 & ${ }^{3} 0.32$ & HAL-US & 40 & $D$ \\
\hline Nickel & 01065 & $7440-02-0$ & ${ }^{2} 0.36$ & $M C L-C A$ & 100 & $D$ \\
\hline Selenium & 01145 & $7782-49-2$ & $0.06,0.040$ & MCL-US & 50 & $D$ \\
\hline Silver & 01075 & $7440-22-4$ & $0.008,0.010$ & SM CL-CA & 100 & $D$ \\
\hline Strontium & 01080 & $7440-24-6$ & $0.8,0.40$ & HAL-US & 4,000 & $D$ \\
\hline Thallium & 01057 & $7440-28-0$ & $0.04,0.020$ & MCL-US & 2 & $D$ \\
\hline Tungsten & 01155 & $7440-33-7$ & ${ }^{2} 0.11$ & na & na & $\mathrm{D}$ \\
\hline Uranium & 22703 & 7440-61-1 & $0.006,0.008$ & MCL-US & 30 & $D$ \\
\hline Vanadium & 01085 & $7440-62-2$ & ${ }^{2} 0.11$ & NL-CA & 50 & $\mathrm{D}$ \\
\hline Zinc & 01090 & $7440-66-6$ & 24.8 & ${ }^{4} \mathrm{SMCL}-\mathrm{CA}$ & 5,000 & $D$ \\
\hline
\end{tabular}

\footnotetext{
${ }^{1}$ For constituents with two LRLs listed, the first value was in use before 09-30-10, and the second value was in use after
} 10-01-10. The highest LRL is used for this report.

${ }^{2}$ SRL was defined based on examination of GAMA quality-control samples collected from May 2004 through January 2008 (OIsen and others, 2010). Values less than the SRL are reported as less than or equal to the value reported by the laboratory. In the USGS NWIS database, the result is accompanied with the following comment: Result is < or = reported value, based on QC data (may include: field blanks, source-solution blanks, trip blanks, NWQL set blanks, NWQL blank water certificates, and USGS BQS B lind Blank Program data).

${ }^{3}$ SRL was defined based on a detection in a field blank. Values less than the SRL are reported as $\leq$ the value reported by the laboratory. In the USGS NWIS database, the result is accompanied with the following comment: Result is < or = reported value, based on a detection in a field blank.

${ }^{4}$ The secondary maximum contaminant level for zinc is listed as SM CL-CA because SM CL s established by the CDPH are used in this report for all constituents that have SM CL-CA values. 
Table 3F. Nutrients, comparative benchmarks, and reporting information for the U.S. Geological Survey (USGS) National Water Quality Laboratory (NWQL) Schedule 2755.

[The five-digit USGS parameter code is used to uniquely identify a specific constituent or property. Benchmark type and benchmark level as of October 1, 2008. Benchmark type: M aximum contaminant level benchmarks are listed as M CL-US when the M CL-US and M CL-CA are identical, and as M CL-CA when the M CL-CA is lower than the M CL-US or no M CL-US exists. HAL-US, U.S. Environmental Protection A gency (USEPA) lifetime health advisory level; M CL-US, USEPA maximum contaminant level. Other abbreviations: CAS, Chemical A bstract Service; LRL, laboratory reporting level; D, detected in groundwater samples (table 9); na, not available; mg/L, milligrams per liter]

\begin{tabular}{|c|c|c|c|c|c|c|}
\hline Constituent & $\begin{array}{l}\text { USGS } \\
\text { parameter } \\
\text { code }\end{array}$ & $\begin{array}{l}\text { CAS } \\
\text { number }\end{array}$ & $\begin{array}{l}\text { LRL }^{1} \\
(\mathbf{m g} / \mathbf{L})\end{array}$ & $\begin{array}{l}\text { Benchmark } \\
\text { type }\end{array}$ & $\begin{array}{l}\text { Benchmark } \\
\text { level }\end{array}$ & Detection \\
\hline A mmonia (as nitrogen) & 00608 & $7664-41-7$ & 0.02 & HAL-US & 224.7 & D \\
\hline $\begin{array}{l}\text { Nitrate plus nitrite (as } \\
\text { nitrogen) }\end{array}$ & 00631 & na & 0.04 & MCL-US & 10 & D \\
\hline Nitrite (as nitrogen) & 00613 & $14797-65-0$ & 0.002 & MCL-US & 1 & D \\
\hline $\begin{array}{l}\text { Total nitrogen (ammonia, } \\
\text { nitrite, nitrate, organic } \\
\text { nitrogen) }\end{array}$ & 62854 & $17778-88-0$ & $0.1,0.10$ & na & na & D \\
\hline $\begin{array}{l}\text { Phosphate, orthophosphate } \\
\text { (as phosphorus) }\end{array}$ & 00671 & $14265-44-2$ & 0.006 & na & na & D \\
\hline
\end{tabular}

\footnotetext{
${ }^{1}$ For constituents with two LRLs listed, the first value was in use before 09-30-10, and the second value was in use after 10-01-10. The highest $L R L$ is used for this report.

2 The HAL-US is $30 \mathrm{mg} / \mathrm{L}$ "as ammonia." To facilitate comparson to the analytical results, we have converted and reported this HAL-US as $24.7 \mathrm{mg} / \mathrm{L}$ "as nitrogen."
} 
Table 3G. Major and minor ions, silica, total dissolved solids (TDS), and alkalinity, comparative benchmarks, and reporting information for the U.S. Geological Survey (USGS) National Water Quality Laboratory (NWOL) Schedule 1948.

[The five-digit USGS parameter code is used to uniquely identify a specific constituent or property. Benchmark type and benchmark level as of October 1, 2008. Benchmark type: M aximum contaminant level benchmarks are listed as M CL -US when the M CL -US and MCL-CA are identical, and as MCL-CA when the MCL-CA is lower than the MCL-US or no MCL-US exists. MCL-CA, California Department of Public Health (CDPH) maximum contaminant level; SM CL-CA, CDPH secondary maximum contaminant level. Other abbreviations: $C A S, C$ hemical A bstract Service; LRL, laboratory reporting level; $D$, detected in groundwater samples (table 10); na, not available; $\mathrm{mg} / \mathrm{L}$, milligrams per liter]

\begin{tabular}{|c|c|c|c|c|c|c|}
\hline Constituent & $\begin{array}{c}\text { USGS } \\
\text { parameter } \\
\text { code }\end{array}$ & $\begin{array}{c}\text { CAS } \\
\text { number }\end{array}$ & $\begin{array}{l}\mathrm{LRL}^{1} \\
\text { (mg/L) }\end{array}$ & $\begin{array}{c}\text { Benchmark } \\
\text { type }\end{array}$ & $\begin{array}{c}\text { Benchmark } \\
\text { level }\end{array}$ & Detection \\
\hline Bromide & 71870 & 24959-67-9 & 0.02 & na & na & $D$ \\
\hline Calcium & 00915 & $7440-70-2$ & $0.02,0.044$ & na & na & D \\
\hline Chloride & 00940 & $16887-00-6$ & 0.12 & SMCL-CA & ${ }^{2} 250(500)$ & D \\
\hline Fluoride & 00950 & $16984-48-8$ & 0.08 & $M C L-C A$ & 2 & D \\
\hline lodide & 71865 & $7553-56-2$ & 0.002 & na & na & $\mathrm{D}$ \\
\hline M agnesium & 00925 & $7439-95-4$ & $0.012,0.016$ & na & na & D \\
\hline Potassium & 00935 & $7440-09-7$ & $0.06,0.064$ & na & na & D \\
\hline Sodium & 00930 & $7440-23-5$ & $0.12,0.10$ & na & na & D \\
\hline Sulfate & 00945 & 14808-79-8 & 0.18 & SM CL-CA & ${ }^{2} 250(500)$ & D \\
\hline Silica (as $\mathrm{SiO}_{2}$ ) & 00955 & $7631-86-9$ & $0.02,0.058$ & na & na & $D$ \\
\hline TDS & 70300 & na & 10 & SMCL-CA & $2500(1,000)$ & D \\
\hline $\begin{array}{l}\text { Laboratory alkalinity } \\
\qquad\left(\text { as } \mathrm{CaCO}_{3}\right)^{3}\end{array}$ & 29801 & na & 1 & na & na & $D$ \\
\hline
\end{tabular}

\footnotetext{
${ }^{1}$ For constituents with two LRLs listed, the first value was in use before 09-30-10, and the second value was in use after 10-01-10. The highest $L R L$ is used for this report.

${ }^{2}$ The recommended SM CL -CA benchmarks for chloride, sulfate, and TDS are listed with the upper SM CL-CA benchmarks in parentheses.

${ }^{3}$ Laboratory alkalinity results are presented in table 4.
} 
Table 3H. Species of inorganic chromium, comparative benchmarks, and reporting information for the U.S. Geological Survey Trace Metal Laboratory, Boulder, Colorado, analyses.

[The five-digit USGS parameter code is used to uniquely identify a specific constituent or property. Method detection limit, benchmark type, and benchmark level as of November 17, 2008. Benchmark type: M aximum contaminant level benchmarks are listed as MCL-US when the MCL-US and M CL-CA are identical, and as M CL-CA when the M CL-CA is lower than the M CL-US or no M CL-US exists. M CL-CA, California Department of Public Health maximum contaminant level. Other abbreviations: CAS, Chemical A bstract Service; M DL, method detection limit; Cr-VI, hexavalent chromium (chromium-VI); na, not available; $\mu \mathrm{g} / \mathrm{L}$, micrograms per liter; D, detected in groundwater samples (table 11); N W IS, USGS N ational Water Information System]

\begin{tabular}{lcccccc}
\hline Constituent & $\begin{array}{c}\text { USGS } \\
\text { parameter } \\
\text { code }^{\mathbf{1}}\end{array}$ & $\begin{array}{c}\text { CAS } \\
\text { number }\end{array}$ & $\begin{array}{c}\text { MDL } \\
(\boldsymbol{\mu} \mathbf{g} / \mathbf{L})\end{array}$ & $\begin{array}{c}\text { Benchmark } \\
\text { type }\end{array}$ & $\begin{array}{c}\text { Benchmark } \\
\text { level } \\
(\boldsymbol{\mu g} / \mathbf{L})\end{array}$ & Detection \\
\hline Chromium (total) & 01030 & $7440-47-3$ & 1 & $\mathrm{MCL}-\mathrm{CA}$ & 50 & $\mathrm{D}$ \\
Cr-VI & 01032 & $18540-29-9$ & 1 & na & na & $\mathrm{D}$ \\
\hline
\end{tabular}

${ }^{1}$ Data are generated from research methods and not stored in the USGS N W IS database under the listed parameter code.

Table 3l. Hexavalent chromium (chromium-VI, Cr-VI), comparative benchmark, and reporting information for the TestAmerica Laboratories, Inc., Irvine, California, analyses.

[The five-digit USGS parameter code is used to uniquely identify a specific constituent or property. Method detection limit as of October 5, 2009. Abbreviations: CAS, Chemical A bstract Service; M DL, method detection limit; na, not available; $\mu \mathrm{g} / \mathrm{L}$, micrograms per liter; D, detected in groundwater samples (table 12)]

\begin{tabular}{lcccccc}
\hline Constituent & $\begin{array}{c}\text { USGS } \\
\text { parameter } \\
\text { code }\end{array}$ & $\begin{array}{c}\text { CAS } \\
\text { number }\end{array}$ & $\begin{array}{c}\text { MDL } \\
(\mu \mathrm{g} / \mathrm{L})\end{array}$ & $\begin{array}{c}\text { Benchmark } \\
\text { type }\end{array}$ & $\begin{array}{c}\text { Benchmark } \\
\text { level }\end{array}$ & Detection \\
\hline $\mathrm{Cr}-\mathrm{VI}$ & 01032 & $18540-29-9$ & 1 & na & na & $\mathrm{D}$ \\
\hline
\end{tabular}


Table 3J. Isotopic and radioactive constituents, comparative benchmarks, and reporting information for laboratory analyses.

[The five-digit USGS parameter code is used to uniquely identify a specific constituent or property. Stable isotope ratios are reported in the standard delta notation $(\delta)$, the ratio of a heavier isotope to more common lighter isotope of that element, relative to a standard reference material. Reporting level, benchmark type, and benchmark level as of October 1, 2008. Benchmark type: M aximum contaminant level benchmarks are listed as M CL-US when the M CL-US and M CL-CA are identical, and as M CL-CA when the M CL-CA is lower than the M CL-US or no M CL-US exists. M CL-US, U.S. Environmental Protection A gency maximum contaminant level; M CL-CA, California Department of Public Health maximum contaminant level. Other abbreviations: USGS, U.S. G eological Survey; CA S, Chemical A bstract Service; CSU, combined standard uncertainty; sSL ${ }_{C}$, sample-specific critical level; MRL, minimum reporting level; na, not available; H, hydrogen; O, oxygen; B, boron; Sr, strontium; pCi/L, picocuries per liter; D, detected in groundwater samples (tables $\underline{13}$ and $\underline{14 \mathrm{~A}}$ through $\underline{14 \mathrm{C}}$ ); NRP, USGS National Research Program]

\begin{tabular}{|c|c|c|c|c|c|c|c|}
\hline Constituent & $\begin{array}{c}\text { USGS } \\
\text { parameter } \\
\text { code }\end{array}$ & $\begin{array}{c}\text { CAS } \\
\text { number }\end{array}$ & $\begin{array}{l}\text { Reporting } \\
\text { level type }\end{array}$ & $\begin{array}{c}\text { Reporting } \\
\text { level or } \\
\text { uncertainty }\end{array}$ & $\begin{array}{c}\text { Benchmark } \\
\text { type }\end{array}$ & $\begin{array}{l}\text { Benchmark } \\
\text { level }\end{array}$ & Detection \\
\hline$\delta^{2} \mathrm{H}$ in water ${ }^{1}$ & 82082 & na & MU & 2 & na & na & $\mathrm{D}$ \\
\hline$\delta^{18} 0$ in water ${ }^{1}$ & 82085 & na & MU & 0.20 & na & na & $\mathrm{D}$ \\
\hline$\delta^{11} \mathrm{~B}$ in water ${ }^{2}$ & 62648 & na & MU & na & na & na & $\mathrm{D}$ \\
\hline \multicolumn{8}{|l|}{ Isotope ratios (atom ratio) } \\
\hline $\begin{array}{l}\text { Strontium isotope ratio } \\
\left({ }^{87} \mathrm{Sr} /{ }^{86} \mathrm{Sr}\right)^{2}\end{array}$ & 75978 & na & MU & 0.00005 & na & na & $\mathrm{D}$ \\
\hline \multicolumn{8}{|c|}{ Radioactive constituents (percent modern) } \\
\hline Radon-222 4 & 82303 & $14859-67-7$ & $\mathrm{ssL}_{\mathrm{c}}$ & CSU & MCL-US (Proposed) & 4,000 & $\mathrm{D}$ \\
\hline Tritium 5 & 07000 & $10028-17-8$ & $\mathrm{ssL}_{\mathrm{c}}$ & CSU & MCL-CA & 20,000 & $\mathrm{D}$ \\
\hline Radium-226 6 & 09511 & $13982-63-3$ & ssL & CSU & MCL-US & 75 & $\mathrm{D}$ \\
\hline Radium-228 ${ }^{6}$ & 81366 & 15262-20-1 & $\mathrm{ssL}_{\mathrm{C}}$ & CSU & MCL-US & 75 & $D$ \\
\hline $\begin{array}{l}\text { Gross al pha radioactivity, } \\
72 \text {-hour and } 30 \text {-day counts }{ }^{6}\end{array}$ & 62636,62639 & $12587-46-1$ & $\mathrm{ssL}_{\mathrm{C}}$ & CSU & MCL-US & 15 & $\mathrm{D}$ \\
\hline $\begin{array}{l}\text { Gross beta radioactivity, } \\
72 \text {-hour and } 30 \text {-day counts } 6\end{array}$ & 62642,62645 & $12587-47-2$ & $\mathrm{ssL}_{\mathrm{C}}$ & CSU & MCL-CA & 50 & $D$ \\
\hline
\end{tabular}

${ }^{1}$ USGS Stable Isotope L aboratory, Reston, Virginia (USGSSIVA).

2 USGS NRP M etals I sotope Research L aboratory, M enlo Park, California (USGSM ICA).

${ }^{3}$ Woods Hole Oceanographic Institution, National Ocean Sciences A ccelerator M ass Spectrometry Facility (contract laboratory, M A-W HA M S).

${ }^{4}$ USGS National Water Quality Laboratory (USGSNW QL).

${ }^{5}$ USGS Stable Isotope and Tritium L aboratory, M enlo Park, California (USGSH3CA).

${ }^{6}$ Eberline A nalytical Services, Richmond, California (contract laboratory, CA-EBERL).

${ }^{7}$ The M CL-US benchmark for radium is the sum of radium-226 and radium-228. 
Table 3K. Dissolved noble gases and tritium, comparison benchmarks, and reporting information for the Lawrence Livermore National Laboratory, Livermore, California, analyses.

[The five-digit USGS parameter code is used to uniquely identify a specific constituent or property. Method uncertainty, benchmark type, and benchmark values as of October 1, 2008. Benchmark type: $M$ aximum contaminant level benchmarks are listed as M CL-US when the M CL-US and M CL-CA are identical, and as MCL-CA when the M CL-CA is lower than the M CL-US or no M CL-US exists. M CL -CA, California D epartment of Public Health maximum contaminant level. Other abbreviations: CAS, Chemical A bstract Service; MU, method uncertainty; na, not available; $\mathrm{cm}^{3} \mathrm{STP} / \mathrm{g}$, cubic centimeters of gas at standard temperature and pressure per gram of water; $\mathrm{pCi} / \mathrm{L}$, picocuries per liter]

\begin{tabular}{|c|c|c|c|c|c|c|c|}
\hline Constituent & $\begin{array}{c}\text { USGS } \\
\text { parameter } \\
\text { code }\end{array}$ & $\begin{array}{c}\text { CAS } \\
\text { number }\end{array}$ & $\begin{array}{c}\text { MU } \\
\text { (percent) }\end{array}$ & $\begin{array}{l}\text { Reporting } \\
\text { units }\end{array}$ & $\begin{array}{c}\text { Benchmark } \\
\text { type }\end{array}$ & $\begin{array}{c}\text { Benchmark } \\
\text { level } \\
\text { (pCi/L) }\end{array}$ & Detection \\
\hline Argon & 85563 & $7440-37-1$ & 2 & $\mathrm{~cm}^{3} \mathrm{STP} / \mathrm{g}$ & na & na & na \\
\hline Helium-4 & 85561 & $7440-59-7$ & 2 & $\mathrm{~cm}^{3} \mathrm{STP} / \mathrm{g}$ & na & na & na \\
\hline Krypton & 85565 & $7439-90-9$ & 2 & $\mathrm{~cm}^{3} \mathrm{STP} / \mathrm{g}$ & na & na & na \\
\hline Neon & 61046 & 7440-01-09 & 2 & $\mathrm{~cm}^{3} \mathrm{STP} / \mathrm{g}$ & na & na & na \\
\hline Xenon & 85567 & $7440-63-3$ & 2 & $\mathrm{~cm}^{3} \mathrm{STP} / \mathrm{g}$ & na & na & na \\
\hline Tritium & 07000 & $10028-17-8$ & 1 & $\mathrm{pCi} / \mathrm{L}$ & MCL-CA & 20,000 & na \\
\hline Helium-3 / Helium-4 & 61040 & na / 7440-59-7 & 0.75 & atom ratio & na & na & na \\
\hline
\end{tabular}


Table 4

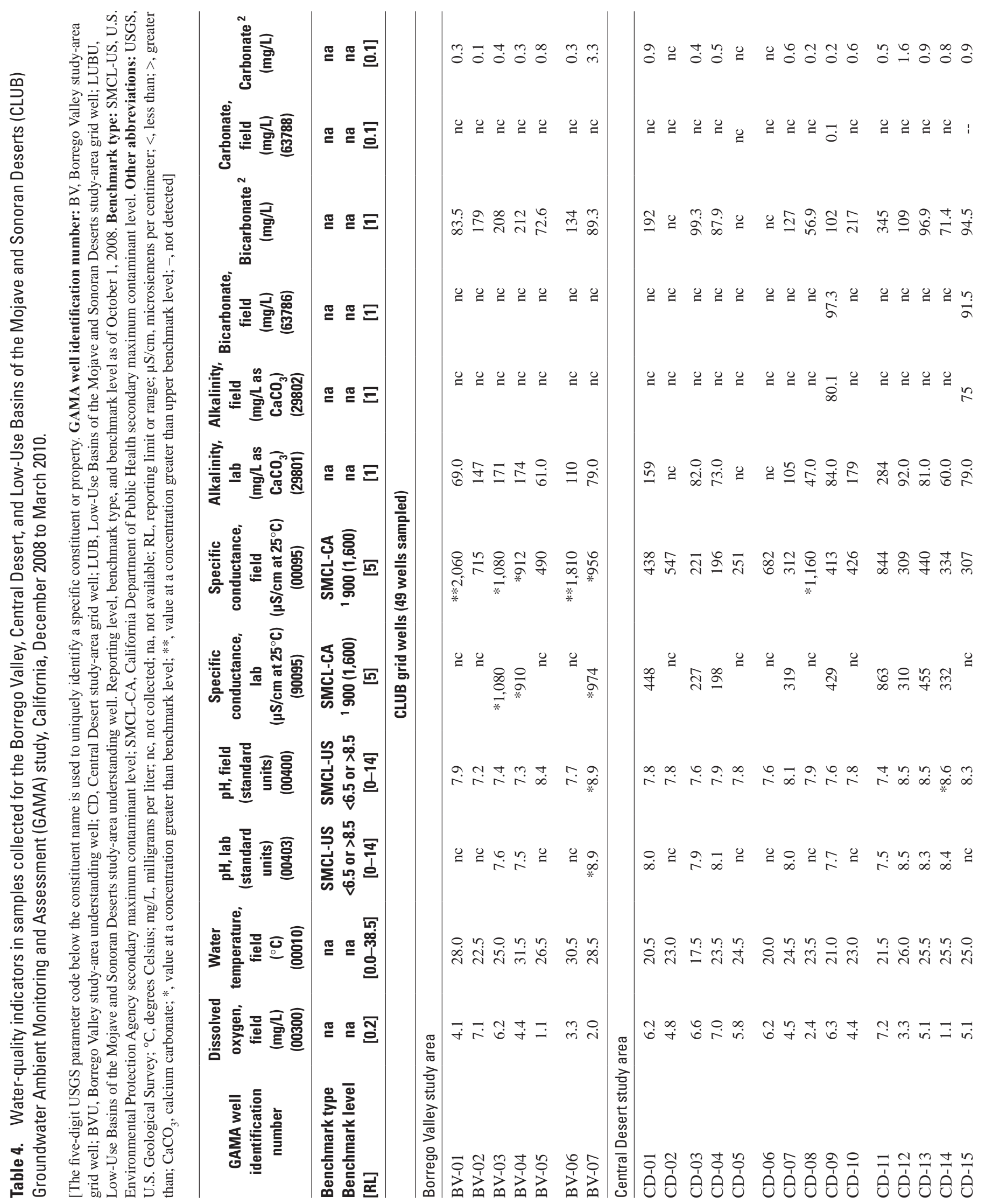



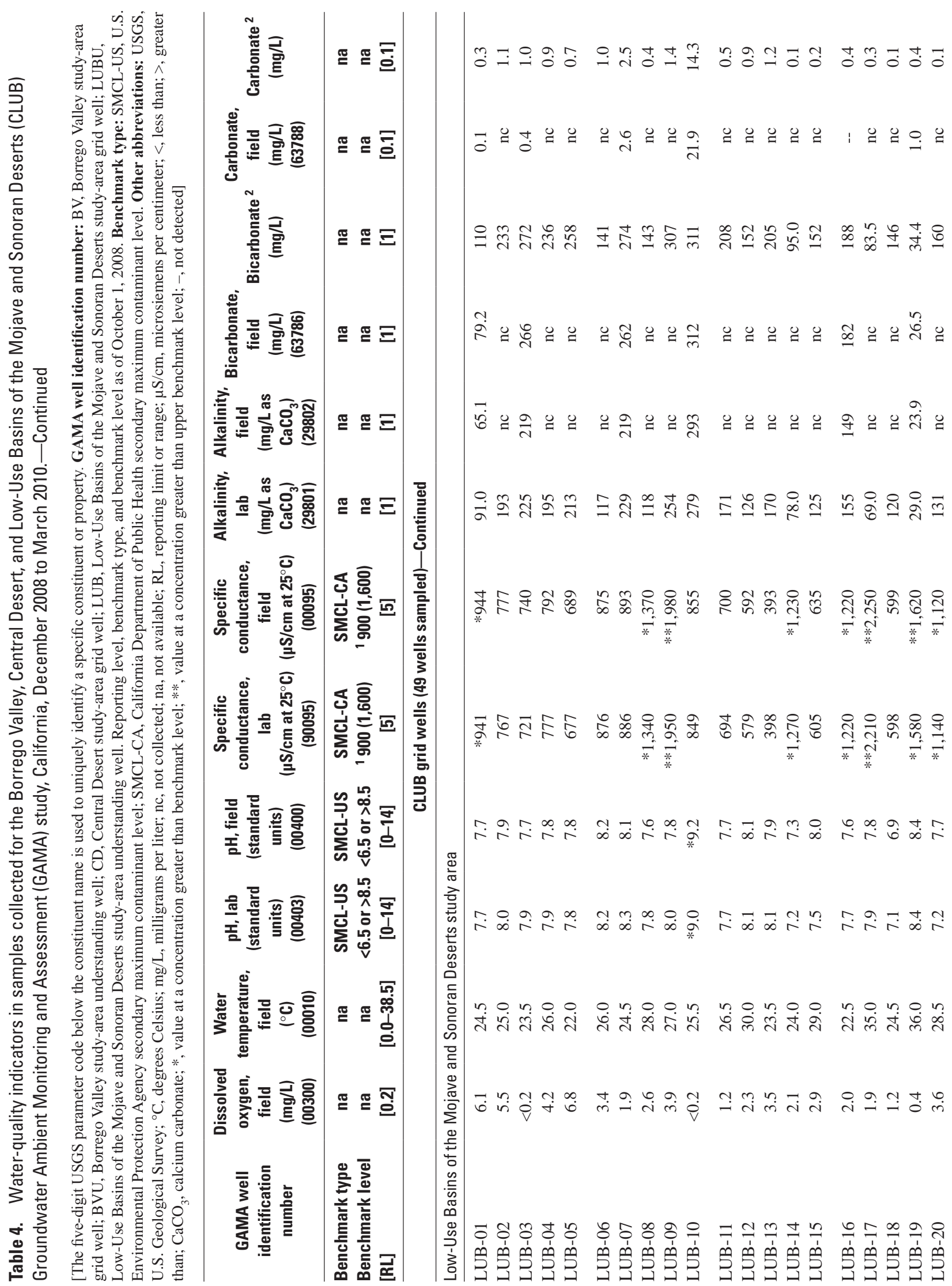


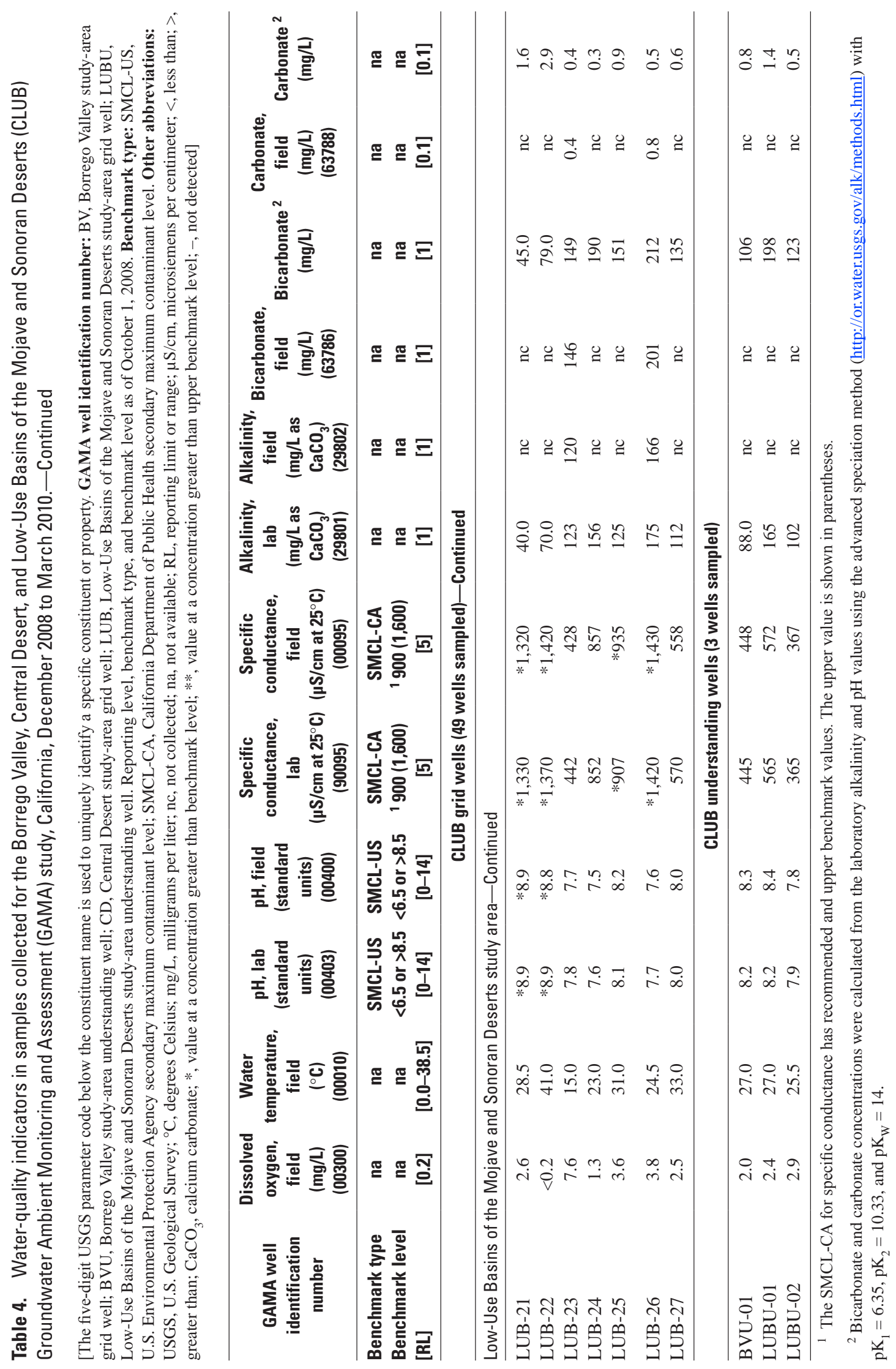




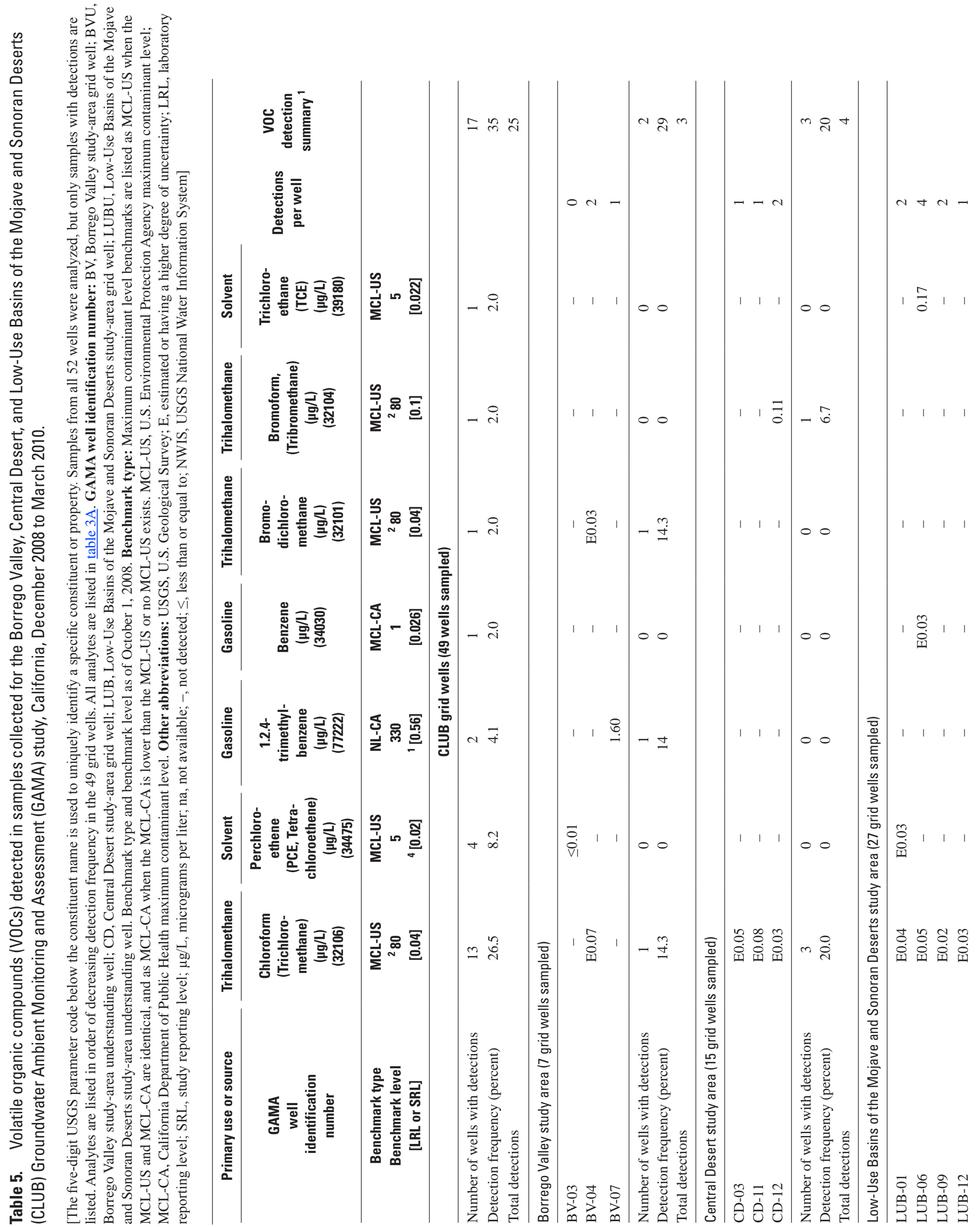




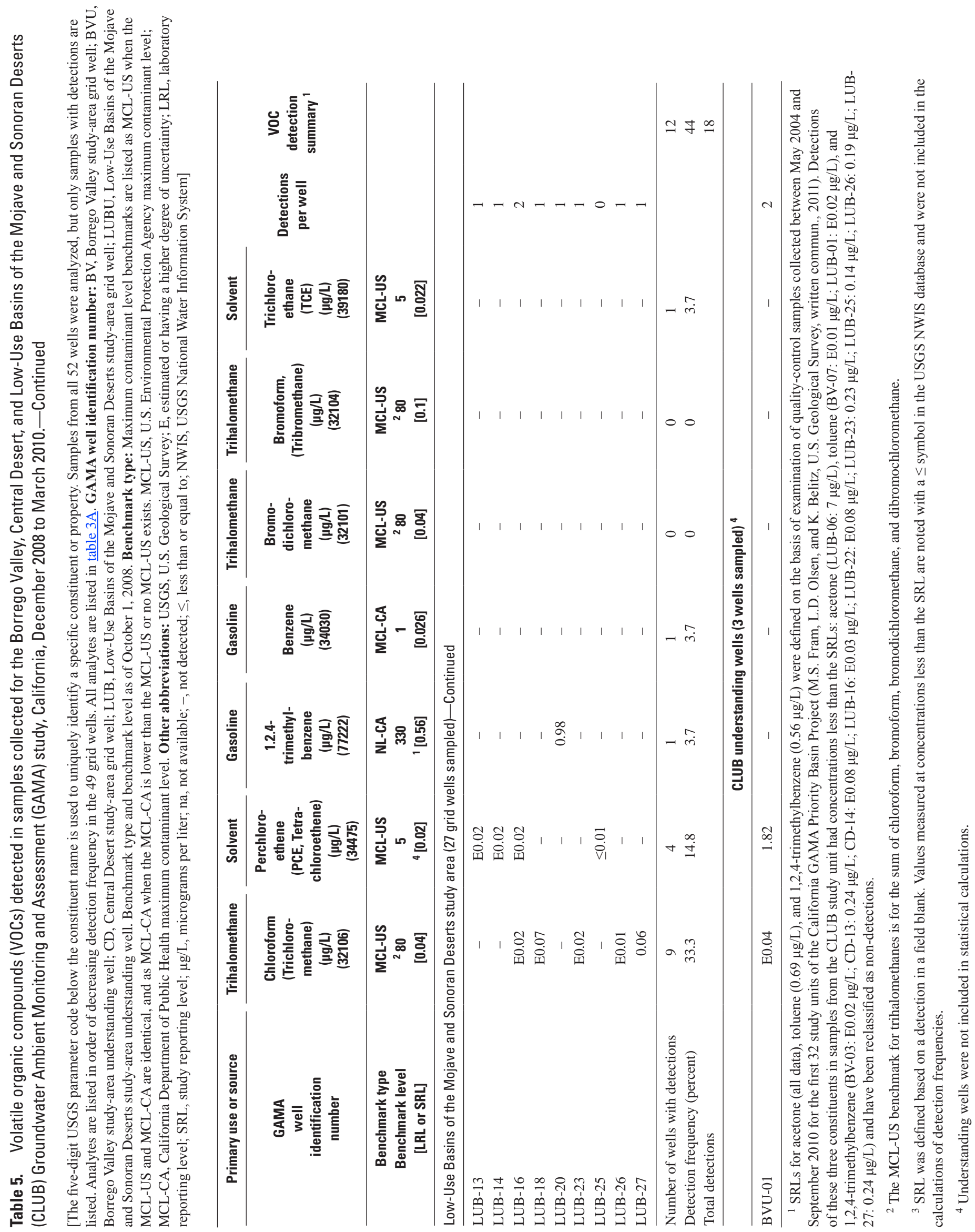


Table 6. Pesticides and pesticide degradates detected in samples collected for the Borrego Valley, Central Desert, and Low-Use Basins of the Mojave and Sonoran Deserts (CLUB) Groundwater Ambient Monitoring and Assessment (GAMA) study, California, December 2008 to March 2010.

[The five-digit USGS parameter code below the constituent name is used to uniquely identify a specific constituent or property. Samples from 50 wells were analyzed, but only samples with detections are listed. A nalytes are listed in order of decreasing detection frequency in the $47 \mathrm{grid}$ wells sampled. All analytes are listed in table 3B. GAMA well identification number: CD, Central Desert study-area grid well; LUB, Low-U se Basins of the M ojave and Sonoran Deserts study-area grid well. B enchmark type and benchmark level as of October 1, 2008. Benchmark type: $M$ aximum contaminant level benchmarks are listed as MCL-US when the MCL-US and MCL-CA are identical, and as M CL-CA when the M CL-CA is lower than the M CL-US or no M CL-US exists. M CL-CA, California Department of Public Health maximum contaminant level; M CL -US, U.S. Environmental Protection A gency (USEPA) maximum contaminant level; HAL-US, USEPA lifetime health advisory level. Other abbreviations: USGS, U.S. Geological Survey; E, estimated or having a higher degree of uncertainty; $L R L$, laboratory reporting level; $\mu \mathrm{g} / \mathrm{L}$, micrograms per liter; na, not available; -, not detected]

\begin{tabular}{|c|c|c|c|c|c|c|c|c|}
\hline Primary use or source & Herbicide & $\begin{array}{l}\text { Herbicide } \\
\text { degradate }\end{array}$ & Herbicide & $\begin{array}{l}\text { Herbicide } \\
\text { degradate }\end{array}$ & Herbicide & $\begin{array}{l}\text { Insecticide } \\
\text { degradate }\end{array}$ & & \\
\hline $\begin{array}{l}\text { GAMA well } \\
\text { identification number }\end{array}$ & $\begin{array}{c}\text { Atrazine } \\
(\mu \mathrm{g} / \mathrm{L}) \\
(39632)\end{array}$ & $\begin{array}{c}\text { Deethylatrazine } \\
\text { (2-Chloro- } \\
\text { 4-isopropyl- } \\
\text { amino-6-amino- } \\
s \text {-triazine) } \\
(\mu \mathrm{g} / \mathrm{L}) \\
(04040)\end{array}$ & $\begin{array}{c}\text { Simazine } \\
(\mu \mathrm{g} / \mathrm{L}) \\
(04035)\end{array}$ & $\begin{array}{c}\text { 3,4-Di- } \\
\text { chloro- } \\
\text { aniline } \\
(\mu \mathrm{g} / \mathrm{L}) \\
(61625)\end{array}$ & $\begin{array}{l}\text { Metola- } \\
\text { chlor } \\
(\mu \mathrm{g} / \mathrm{L}) \\
(39415)\end{array}$ & $\begin{array}{l}\text { Dieldrin } \\
\text { ( } \mu \mathrm{g} / \mathrm{L}) \\
(39381)\end{array}$ & $\begin{array}{l}\text { Pesticide } \\
\text { detections } \\
\text { per well }\end{array}$ & $\begin{array}{l}\text { Pesticide } \\
\text { detection } \\
\text { summary }\end{array}$ \\
\hline Benchmark type & MCL-CA & na & MCL-US & na & HAL-US & RSD5-US & & \\
\hline $\begin{array}{l}\text { Benchmark level } \\
\text { [LRL] }\end{array}$ & $\begin{array}{c}1 \\
{[0.007]}\end{array}$ & $\begin{array}{c}\text { na } \\
{[0.014]}\end{array}$ & $\begin{array}{c}4 \\
{[0.01]}\end{array}$ & $\begin{array}{c}\text { na } \\
{[0.0042]}\end{array}$ & $\begin{array}{c}700 \\
{[0.014]}\end{array}$ & $\begin{array}{c}0.02 \\
{[0.009]}\end{array}$ & & \\
\hline \multicolumn{9}{|c|}{ CLUB grid wells (47 wells sampled) ${ }^{1}$} \\
\hline $\begin{array}{l}\text { Number of wells with detections } \\
\text { Detection frequency (percent) } \\
\text { Total detections }\end{array}$ & $\begin{array}{l}3 \\
6.4\end{array}$ & $\begin{array}{l}2 \\
4.3\end{array}$ & $\begin{array}{l}2 \\
4.3\end{array}$ & $\begin{array}{l}2 \\
4.3\end{array}$ & $\begin{array}{l}1 \\
2.1\end{array}$ & $\begin{array}{l}1 \\
2.1\end{array}$ & & $\begin{array}{r}5 \\
11 \\
11\end{array}$ \\
\hline \multicolumn{9}{|c|}{ Central Desert study area (13 grid wells sampled) ${ }^{1}$} \\
\hline CD-09 & 0.011 & - & 0.022 & E0.018 & E0.011 & - & 2 & \\
\hline $\begin{array}{l}\text { Number of wells with detections } \\
\text { Detection frequency (percent) } \\
\text { Total detections }\end{array}$ & $\begin{array}{l}1 \\
7.7\end{array}$ & $\begin{array}{l}0 \\
0\end{array}$ & $\begin{array}{l}1 \\
7.7\end{array}$ & $\begin{array}{l}1 \\
7.7\end{array}$ & $\begin{array}{l}1 \\
7.7\end{array}$ & $\begin{array}{l}0 \\
0\end{array}$ & & $\begin{array}{l}1 \\
8 \\
4\end{array}$ \\
\hline \multicolumn{9}{|c|}{ Low-Use Basins of the Mojave and Sonoran Deserts study area (27 grid wells sampled) } \\
\hline $\begin{array}{l}\text { LUB }-01 \\
\text { LUB }-06 \\
\text { LUB }-16 \\
\text { LUB }-27\end{array}$ & $\begin{array}{c}\text { E0.007 } \\
- \\
- \\
\text { E } 0.006\end{array}$ & $\begin{array}{c}E 0.009 \\
- \\
E 0.007 \\
-\end{array}$ & $\begin{array}{l}0.025 \\
- \\
- \\
-\end{array}$ & $\begin{array}{c}\text { E0.005 } \\
- \\
- \\
-\end{array}$ & $\begin{array}{l}- \\
- \\
-\end{array}$ & $\begin{array}{c}- \\
E 0.004 \\
- \\
-\end{array}$ & $\begin{array}{l}4 \\
1 \\
1 \\
1\end{array}$ & \\
\hline $\begin{array}{l}\text { Number of wells with detections } \\
\text { Dectection frequency (percent) } \\
\text { Total detections }\end{array}$ & $\begin{array}{l}2 \\
7.0\end{array}$ & $\begin{array}{l}2 \\
7.0\end{array}$ & $\begin{array}{l}1 \\
3.7\end{array}$ & $\begin{array}{l}1 \\
3.7\end{array}$ & $\begin{array}{l}0 \\
0\end{array}$ & $\begin{array}{l}1 \\
3.7\end{array}$ & & $\begin{array}{r}4 \\
15 \\
7\end{array}$ \\
\hline
\end{tabular}

\footnotetext{
${ }^{1}$ Samples from CD-10 and CD-12 were ruined during sample preparation at the USGS N ational Water Quality Laboratory.
} 
Table 7. Perchlorate detected in the samples collected for the Borrego Valley, Central Desert, and Low-Use Basins of the Mojave and Sonoran Deserts (CLUB) Groundwater Ambient Monitoring and Assessment (GAMA) study, California, December 2008 to March 2010.

[The five-digit USGS parameter code below the constituent name is used to uniquely identify a specific constituent or property. Information about the analyte given in table 3D. Samples from all 52 wells were analyzed for perchlorate, but only samples with detections are listed. GAMA well identification number: BV, B orrego Valley study-area grid well; BVU, B orrego Valley study-area understanding well; CD, Central D esert study-area grid well; LUB, L ow-U se B asins of the M ojave and Sonoran Deserts study-area grid well; LUBU, Low-U se B asins of the M ojave and Sonoran Deserts study-area understanding well. M inimum reporting level, benchmark type, and benchmark level as of October 1, 2008. Benchmark type: M aximum contaminant level benchmarks are listed as M CL-US when the MCL-US and MCL-CA are identical, and as MCL-CA when the MCL-CA is lower than the M CL-US or no M CL-US exists. MCL-CA, California Department of Public Health maximum contaminant level. Other abbreviations: USGS, U.S. Geological Survey; M RL, minimum reporting level; $\mu$ g/L, micrograms per liter]

\begin{tabular}{|c|c|}
\hline $\begin{array}{c}\text { GAMA well } \\
\text { identification } \\
\text { number }\end{array}$ & $\begin{array}{c}\text { Perchlorate } \\
(\mu \mathrm{g} / \mathrm{L}) \\
(63790)\end{array}$ \\
\hline Benchmark type & MCL-CA \\
\hline Benchmark level & 6 \\
\hline [MRL] & {$[0.10]$} \\
\hline \multicolumn{2}{|c|}{ CLUB grid wells (49 wells sampled) } \\
\hline Number of wells with detections & 41 \\
\hline D etection frequency (percent) & 84 \\
\hline \multicolumn{2}{|c|}{ CLUB Borrego Valley study area (7 grid wells sampled) } \\
\hline BV-01 & 0.19 \\
\hline BV-04 & 0.57 \\
\hline BV-06 & 0.88 \\
\hline BV-07 & 0.30 \\
\hline Number of wells with detections & 4 \\
\hline D etection frequency (percent) & 57 \\
\hline \multicolumn{2}{|c|}{ CLUB Central Desert study area (15 grid wells sampled) } \\
\hline CD-01 & 0.48 \\
\hline CD-02 & 0.59 \\
\hline CD-03 & 0.30 \\
\hline CD-04 & 0.39 \\
\hline CD -05 & 0.44 \\
\hline CD-06 & 0.19 \\
\hline CD-07 & 0.43 \\
\hline CD-09 & 0.19 \\
\hline CD-10 & 0.38 \\
\hline CD-11 & 0.52 \\
\hline CD-12 & 0.50 \\
\hline CD-13 & 0.26 \\
\hline CD-14 & 0.29 \\
\hline CD-15 & 0.59 \\
\hline Number of wells with detections & 14 \\
\hline Detection frequency (percent) & 93 \\
\hline
\end{tabular}

\begin{tabular}{lc}
\hline \multicolumn{1}{c}{$\begin{array}{c}\text { GAMA well } \\
\text { identification } \\
\text { number }\end{array}$} & $\begin{array}{c}\text { Perchlorate } \\
(\mu \mathrm{g} / \mathrm{L})\end{array}$ \\
& $(63790)$ \\
\hline Benchmark type & MCL-CA \\
Benchmark level & 6 \\
{$[\mathrm{MRL}]$} & {$[0.10]$}
\end{tabular}

CLUB Low-Use Basins of the Mojave and Sonoran Deserts study area (27 grid wells sampled)

\begin{tabular}{|c|c|}
\hline LUB-01 & 0.28 \\
\hline LUB-02 & 0.17 \\
\hline LUB-04 & 0.14 \\
\hline LUB-05 & 0.55 \\
\hline LUB-06 & 0.67 \\
\hline LUB-07 & 0.28 \\
\hline LUB-08 & 1.12 \\
\hline LUB-09 & 1.83 \\
\hline LUB-11 & 0.64 \\
\hline LUB-12 & 0.35 \\
\hline LUB-13 & 0.33 \\
\hline LUB-14 & 0.37 \\
\hline LUB-15 & 0.28 \\
\hline LUB-16 & 1.29 \\
\hline LUB-17 & 1.87 \\
\hline LUB-19 & 0.10 \\
\hline LUB-20 & 0.33 \\
\hline LUB-21 & 0.87 \\
\hline LUB-23 & 0.95 \\
\hline LUB-24 & 0.47 \\
\hline LUB-25 & 1.48 \\
\hline LUB-26 & 3.59 \\
\hline LUB -27 & 0.71 \\
\hline N umber of wells with detections & 23 \\
\hline D etection frequency (percent) & 85 \\
\hline \multicolumn{2}{|c|}{ CLUB understanding wells ( 3 wells sampled) } \\
\hline BVU-01 & 0.27 \\
\hline LUBU-02 & 0.83 \\
\hline
\end{tabular}



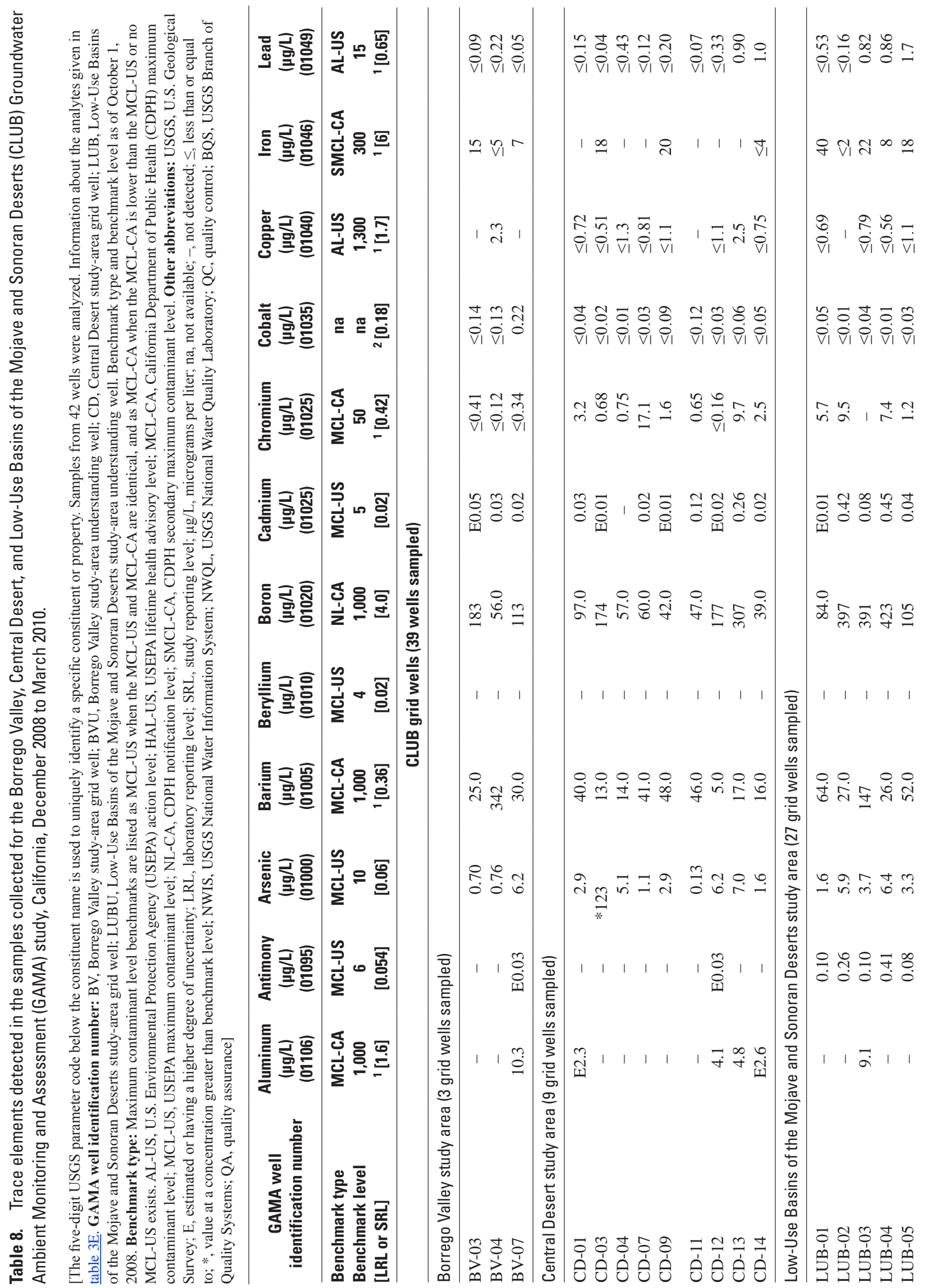

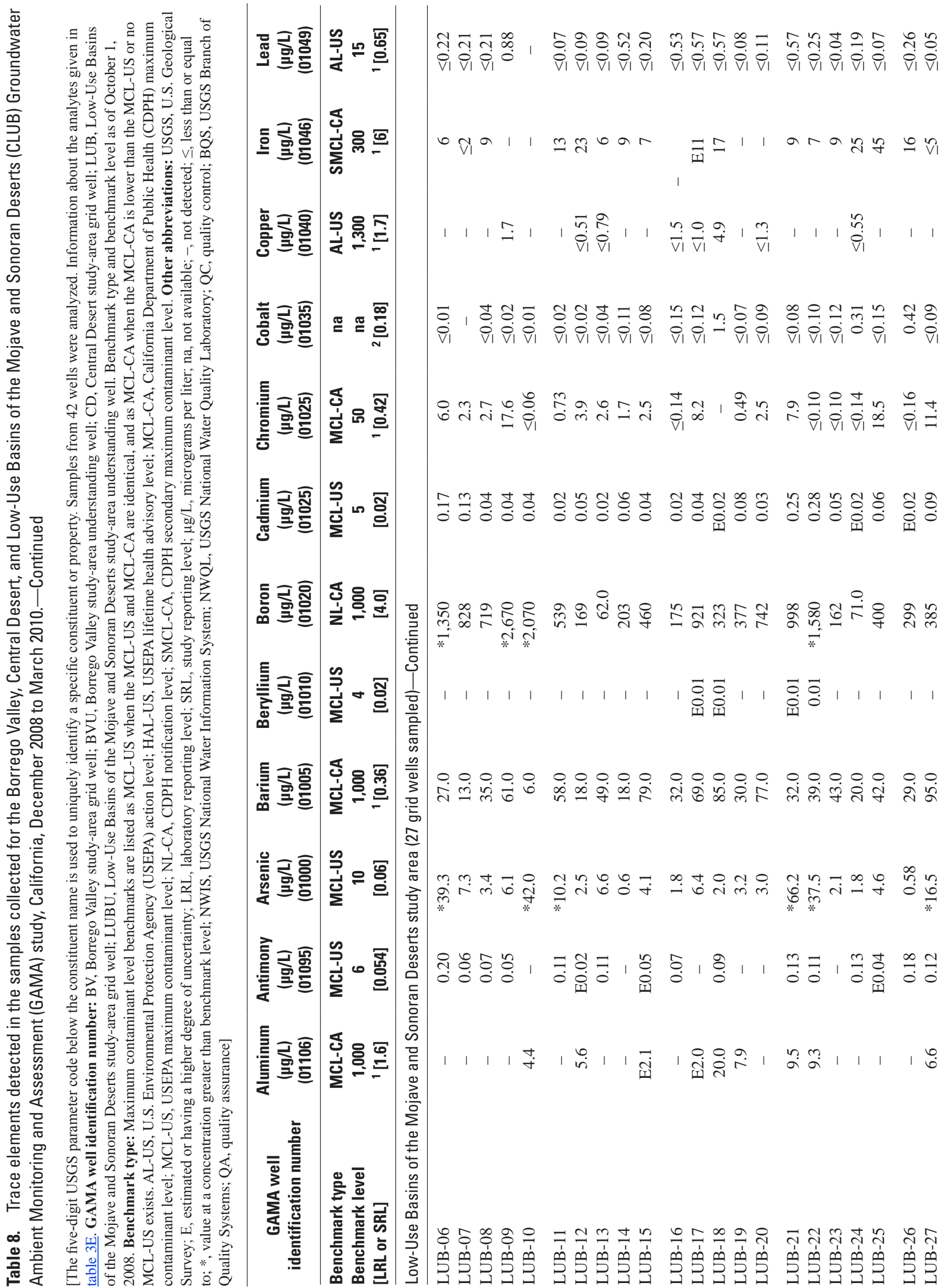


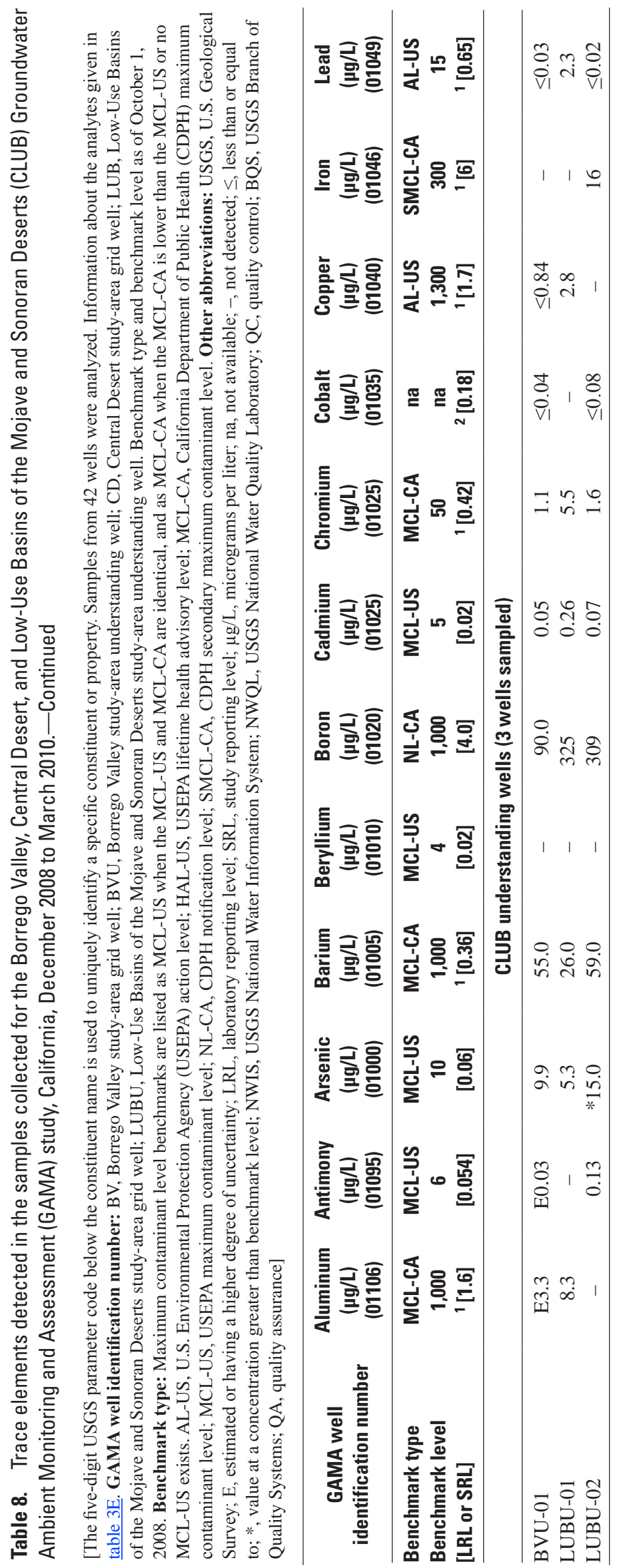


Table 863

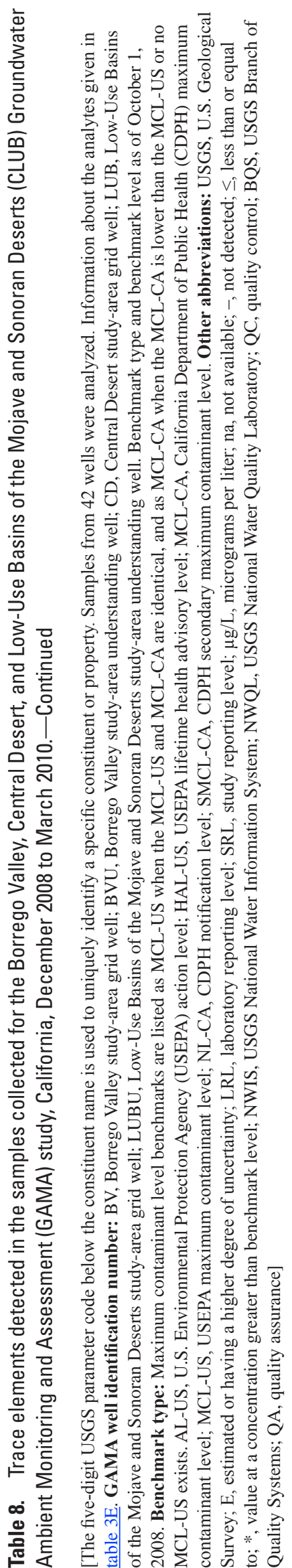

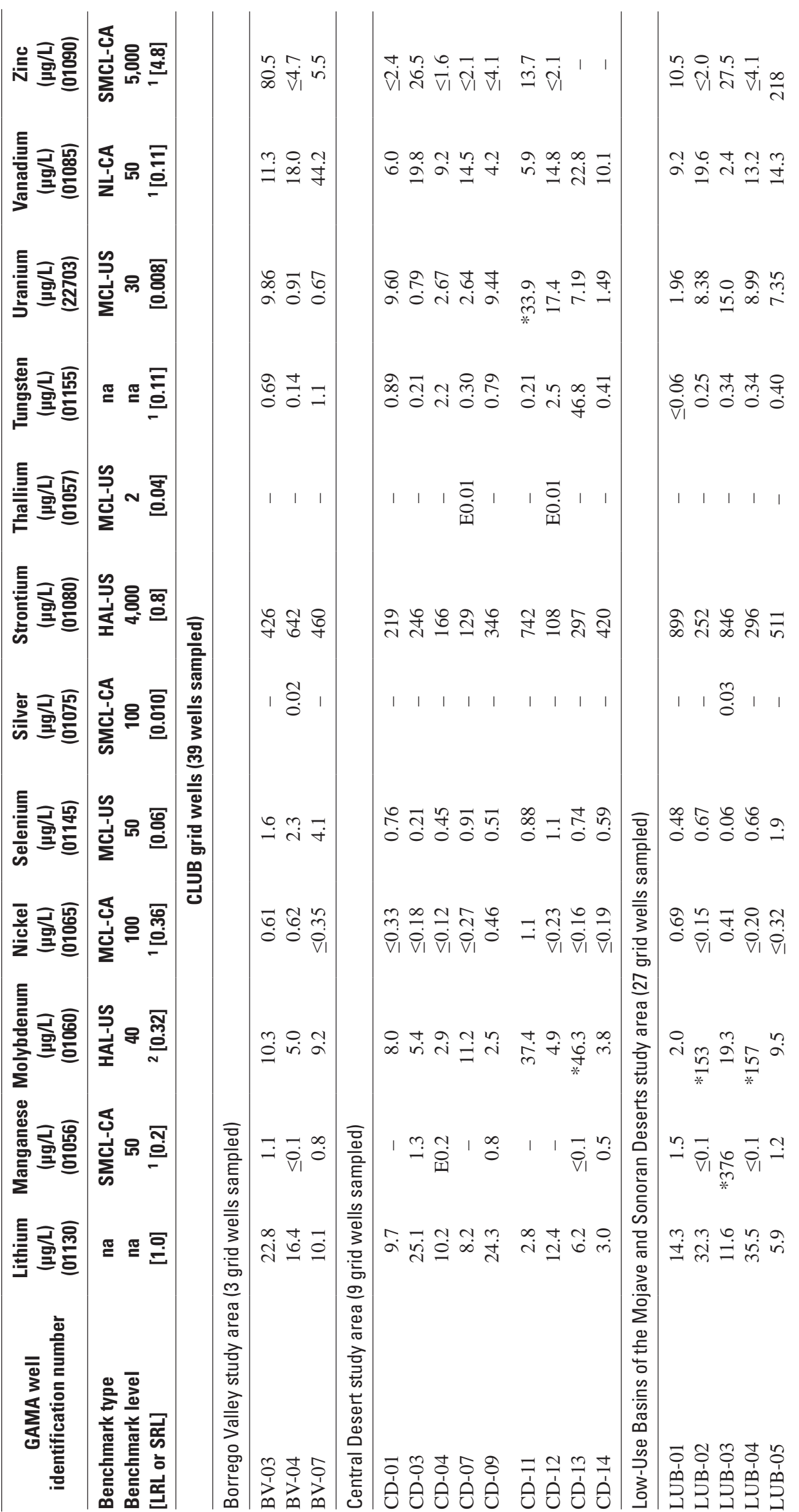



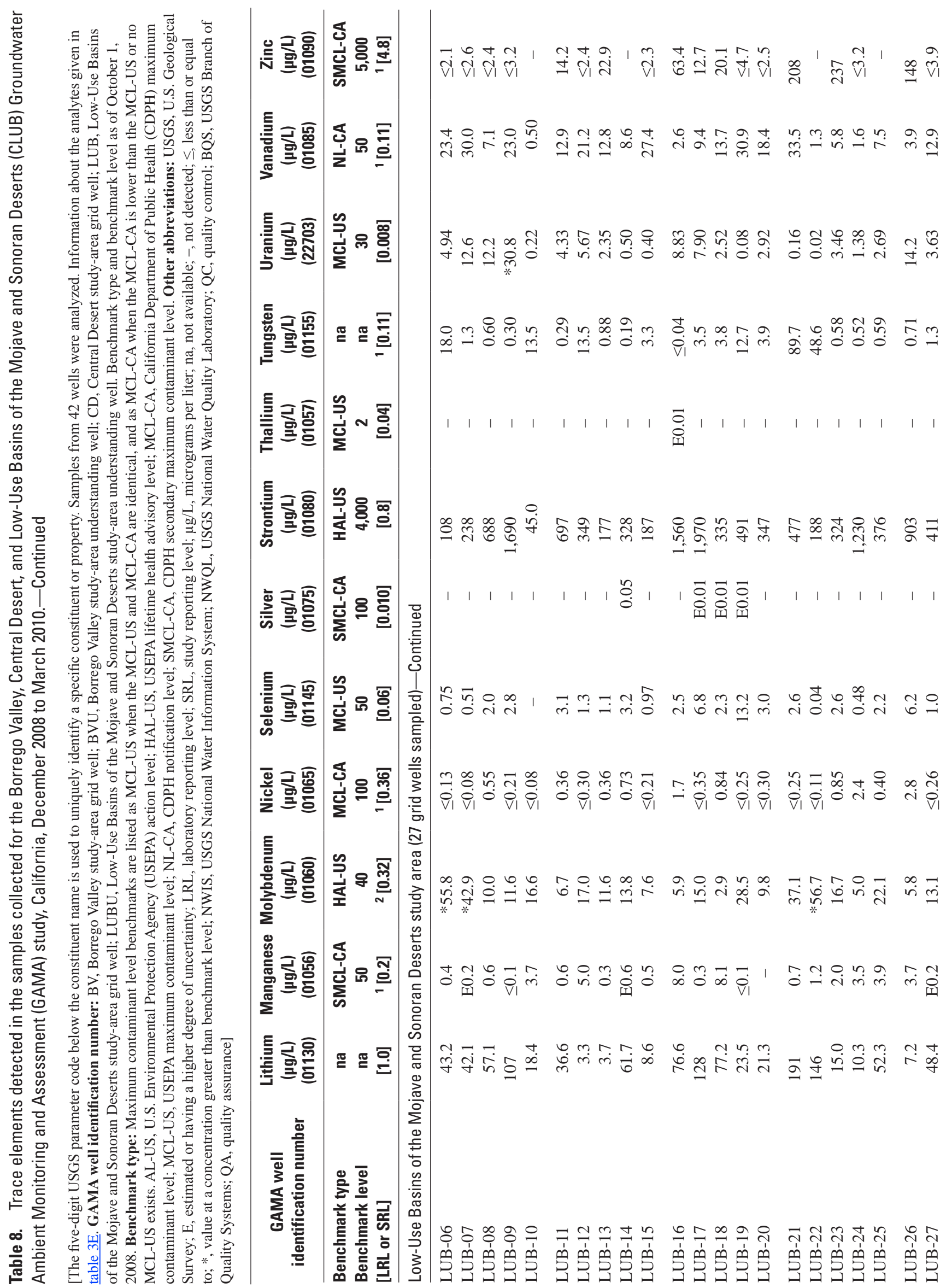


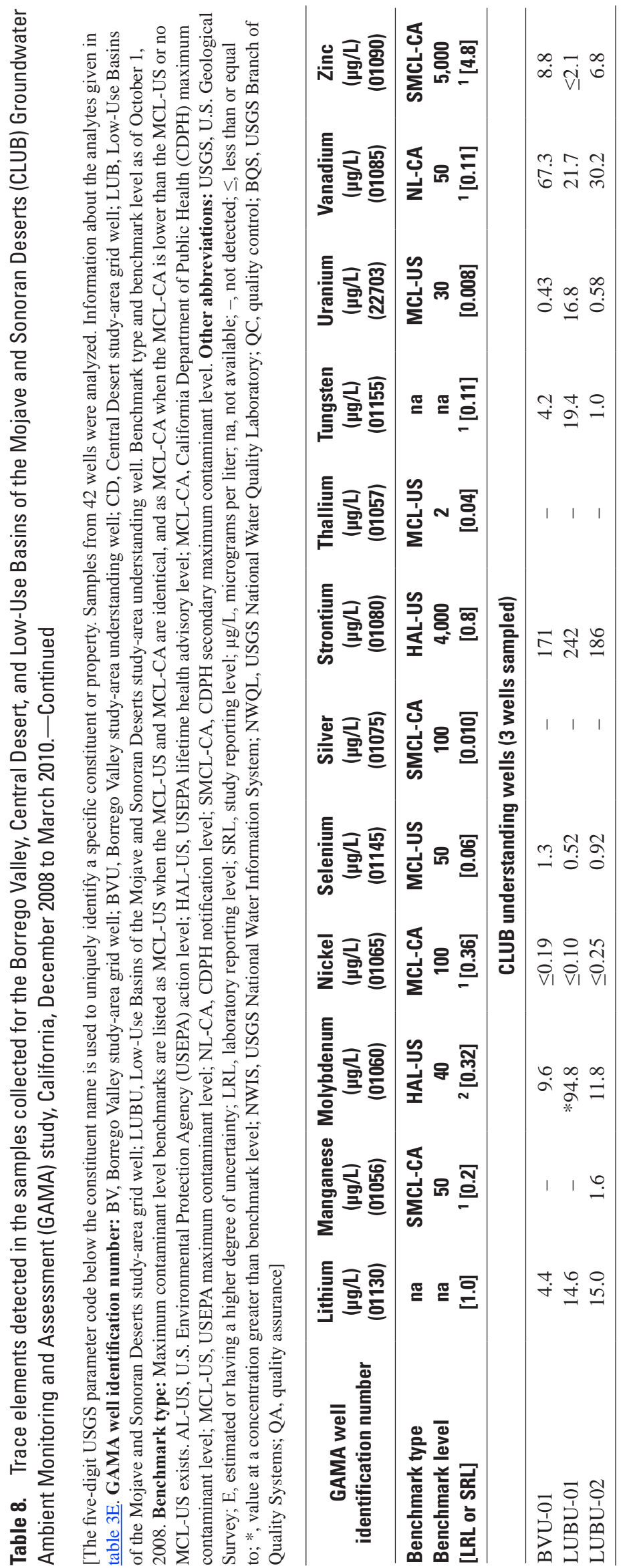


Table 9. Nutrients detected in samples collected for the Borrego Valley, Central Desert, and Low-Use Basins of the Mojave and Sonoran Deserts (CLUB) Groundwater Ambient Monitoring and Assessment (GAMA) study, California, December 2008 to March 2010.

[The five-digit USGS parameter code below the constituent name is used to uniquely identify a specific constituent or property. Samples from 42 wells were analyzed. Information about the analytes given in table 3F. GAMA well identification number: BV, B orrego Valley studyarea grid well; BVU, B orrego Valley study-area understanding well; CD, Central Desert study-area grid well; LUB, Low-U se Basins of the M ojave and Sonoran Deserts study-area grid well; LUBU, L ow-U se B asins of the M ojave and Sonoran Deserts study-area understanding well. B enchmark type and benchmark level as of October 1, 2008. Benchmark type: M aximum contaminant level benchmarks are listed as M CL-US when the MCL-US and MCL-CA are identical, and as MCL-CA when the MCL-CA is lower than the M CL-US or no M CL-US exists. HAL-US, U.S. Environmental Protection A gency (USEPA) lifetime health advisory level; M CL-US, USEPA maximum contaminant level. Other abbreviations: USGS, U.S. G eological Survey; E, estimated or having a higher degree of uncertainty; LRL, laboratory reporting level; mg/L, milligram per liter; na, not available; -, not detected; *, value is at a concentration greater than benchmark level]

\begin{tabular}{|c|c|c|c|c|c|}
\hline $\begin{array}{c}\text { GAMA well } \\
\text { identification } \\
\text { number }\end{array}$ & $\begin{array}{c}\text { Ammonia, } \\
\text { as nitrogen } \\
(\mathrm{mg} / \mathrm{L}) \\
(00608)\end{array}$ & $\begin{array}{l}\text { Nitrite, as } \\
\text { nitrogen } \\
\text { (mg/L) } \\
(00613)\end{array}$ & $\begin{array}{c}\text { Nitrite } \\
\text { plus nitrate, } \\
\text { as nitrogen } \\
\text { (mg/L) } \\
(00631)\end{array}$ & $\begin{array}{c}\text { Total nitrogen } \\
\text { (ammonia + } \\
\text { nitrate + nitrite + } \\
\text { organic-nitrogen) } \\
\text { (mg/L) } \\
(62854)\end{array}$ & $\begin{array}{c}\text { Phosphate, } \\
\text { orthophosphate } \\
\text { (as phosphorus) } \\
\text { (mg/L) } \\
\text { (00671) }\end{array}$ \\
\hline Benchmark type & HAL-US & MCL-US & MCL-US & na & na \\
\hline Benchmark level & 124.7 & 1 & 10 & na & na \\
\hline$[\mathbf{L R L}]$ & {$[0.02]$} & {$[0.002]$} & {$[0.04]$} & {$[0.10]$} & {$[0.006]$} \\
\hline \multicolumn{6}{|c|}{ CLUB grid wells (39 wells sampled) } \\
\hline \multicolumn{6}{|c|}{ Borrego Valley study area (3 grid wells sampled) } \\
\hline BV-03 & - & - & 0.28 & 20.27 & 0.019 \\
\hline BV-04 & - & - & 2.44 & 2.46 & 0.033 \\
\hline BV-07 & - & E0.001 & 0.99 & 1.01 & 0.013 \\
\hline \multicolumn{6}{|c|}{ Central Desert study area ( 9 grid wells sampled) } \\
\hline CD-01 & - & - & 1.55 & ${ }^{2} 1.51$ & 0.016 \\
\hline CD-03 & - & - & 2.03 & 2.06 & 0.025 \\
\hline CD-04 & - & - & 1.41 & 1.42 & 0.018 \\
\hline CD-07 & - & - & 2.62 & 2.68 & 0.027 \\
\hline CD-09 & - & - & 2.20 & 2.25 & 0.027 \\
\hline CD-11 & - & - & 1.24 & 1.30 & 0.027 \\
\hline CD-12 & - & E0.001 & 1.90 & 2.00 & 0.014 \\
\hline CD-13 & - & - & 1.63 & 1.91 & 0.009 \\
\hline CD-14 & - & E0.001 & 1.19 & 1.20 & 0.009 \\
\hline \multicolumn{6}{|c|}{ Low-Use Basins of the Mojave and Sonoran Deserts study area (27 grid wells sampled) } \\
\hline LUB-01 & - & - & $* 12.1$ & 12.3 & 0.011 \\
\hline LUB-02 & - & - & 0.41 & 20.39 & 0.022 \\
\hline LUB-03 & 0.04 & 0.011 & 0.09 & ${ }^{2} \mathrm{E} 0.10$ & 0.051 \\
\hline LUB-04 & - & - & 0.38 & 20.36 & 0.017 \\
\hline LUB-05 & - & - & 1.03 & 1.04 & 0.012 \\
\hline LUB-06 & - & 0.014 & 3.60 & 23.55 & 0.015 \\
\hline LUB-07 & - & - & 1.57 & ${ }^{2} 1.50$ & 0.011 \\
\hline LUB-08 & - & - & 4.94 & 4.96 & 0.029 \\
\hline LUB-09 & - & - & 5.11 & 5.22 & 0.018 \\
\hline LUB-10 & 0.16 & - & - & 0.21 & 0.096 \\
\hline LUB-11 & - & E0.001 & 4.10 & 24.06 & 0.017 \\
\hline LUB-12 & - & 0.006 & 1.50 & 1.56 & 1.35 \\
\hline LUB-13 & - & - & 0.92 & 0.94 & 0.014 \\
\hline LUB-14 & - & - & 0.60 & ${ }^{2} 0.58$ & 0.024 \\
\hline LUB-15 & - & - & 2.06 & 2.09 & 0.013 \\
\hline
\end{tabular}


Table 9. Nutrients detected in samples collected for the Borrego Valley, Central Desert, and Low-Use Basins of the Mojave and Sonoran Deserts (CLUB) Groundwater Ambient Monitoring and Assessment (GAMA) study, California, December 2008 to March 2010.-Continued

[The five-digit USGS parameter code below the constituent name is used to uniquely identify a specific constituent or property. Samples from 42 wells were analyzed. Information about the analytes given in table 3F. GAMA well identification number: BV, B orrego Valley studyarea grid well; BVU, B orrego Valley study-area understanding well; CD, Central Desert study-area grid well; LUB, Low-U se B asins of the M ojave and Sonoran Deserts study-area grid well; LUBU, L ow-U se Basins of the M ojave and Sonoran Deserts study-area understanding well. B enchmark type and benchmark level as of October 1, 2008. Benchmark type: M aximum contaminant level benchmarks are listed as MCL-US when the MCL-US and M CL-CA are identical, and as M CL-CA when the M CL-CA is lower than the M CL-US or no M CL-US exists. HAL-US, U.S. Environmental Protection A gency (USEPA) lifetime health advisory level; M CL-US, USEPA maximum contaminant level. Other abbreviations: USGS, U.S. Geological Survey; E, estimated or having a higher degree of uncertainty; LRL, laboratory reporting level; mg/L, milligram per liter; na, not available; -, not detected; ${ }^{*}$, value is at a concentration greater than benchmark level]

\begin{tabular}{|c|c|c|c|c|c|}
\hline $\begin{array}{c}\text { GAMA well } \\
\text { identification } \\
\text { number }\end{array}$ & $\begin{array}{l}\text { Ammonia, } \\
\text { as nitrogen } \\
\text { (mg/L) } \\
(00608)\end{array}$ & $\begin{array}{c}\text { Nitrite, as } \\
\text { nitrogen } \\
(\mathrm{mg} / \mathrm{L}) \\
(00613)\end{array}$ & $\begin{array}{c}\text { Nitrite } \\
\text { plus nitrate, } \\
\text { as nitrogen } \\
(\mathrm{mg} / \mathrm{L}) \\
(00631)\end{array}$ & $\begin{array}{c}\text { Total nitrogen } \\
\text { (ammonia + } \\
\text { nitrate + nitrite + } \\
\text { organic-nitrogen) } \\
\text { (mg/L) } \\
(62854)\end{array}$ & $\begin{array}{c}\text { Phosphate, } \\
\text { orthophosphate } \\
\text { (as phosphorus) } \\
\text { (mg/L) } \\
\text { (00671) }\end{array}$ \\
\hline Benchmark type & HAL-US & MCL-US & MCL-US & na & na \\
\hline Benchmark level & 124.7 & 1 & 10 & na & na \\
\hline [LRL] & [0.02] & [0.002] & [0.04] & [0.10] & {$[0.006]$} \\
\hline \multicolumn{6}{|c|}{ Low-Use Basins of the Mojave and Sonoran Deserts study area (27 grid wells sampled)—Continued } \\
\hline LUB-16 & - & - & 0.35 & 0.42 & 0.009 \\
\hline LUB-17 & - & - & 1.35 & 1.41 & E0.008 \\
\hline LUB-18 & - & - & 0.25 & 0.28 & 0.160 \\
\hline LUB-19 & - & - & 1.22 & 21.18 & E0.007 \\
\hline LUB-20 & - & - & 1.71 & 1.77 & 0.018 \\
\hline LUB-21 & - & 0.005 & 4.51 & 4.68 & 0.008 \\
\hline LUB-22 & 0.093 & E0.001 & - & 0.21 & 0.010 \\
\hline LUB-23 & - & - & 1.47 & 1.48 & 0.014 \\
\hline LUB-24 & - & E0.002 & 0.65 & 0.66 & 0.011 \\
\hline LUB-25 & - & 0.002 & 3.03 & 23.02 & E0.008 \\
\hline LUB-26 & - & - & 4.55 & 24.32 & 0.010 \\
\hline LUB-27 & - & - & 2.69 & 2.72 & 0.021 \\
\hline \multicolumn{6}{|c|}{ CLUB understanding wells ( 3 wells sampled) } \\
\hline BVU -01 & - & - & 2.02 & 2.07 & 0.016 \\
\hline LUBU-01 & - & - & 0.33 & 0.34 & 0.011 \\
\hline LUBU-02 & - & 0.004 & 2.48 & 2.52 & 0.042 \\
\hline
\end{tabular}




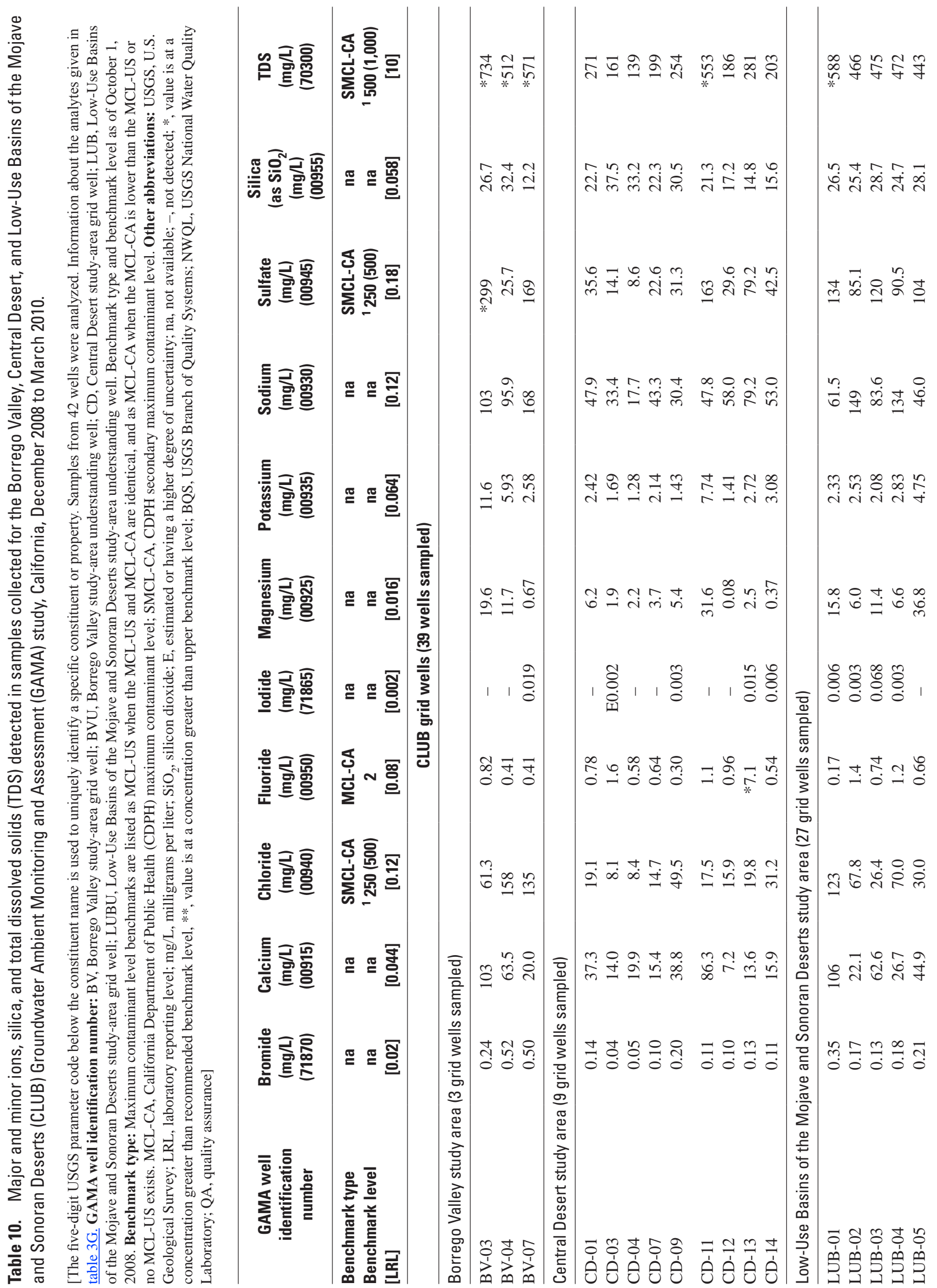




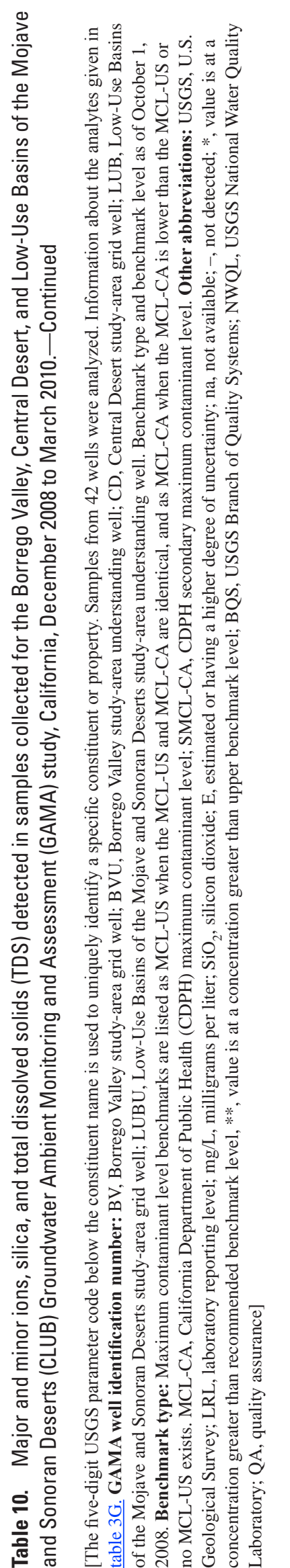

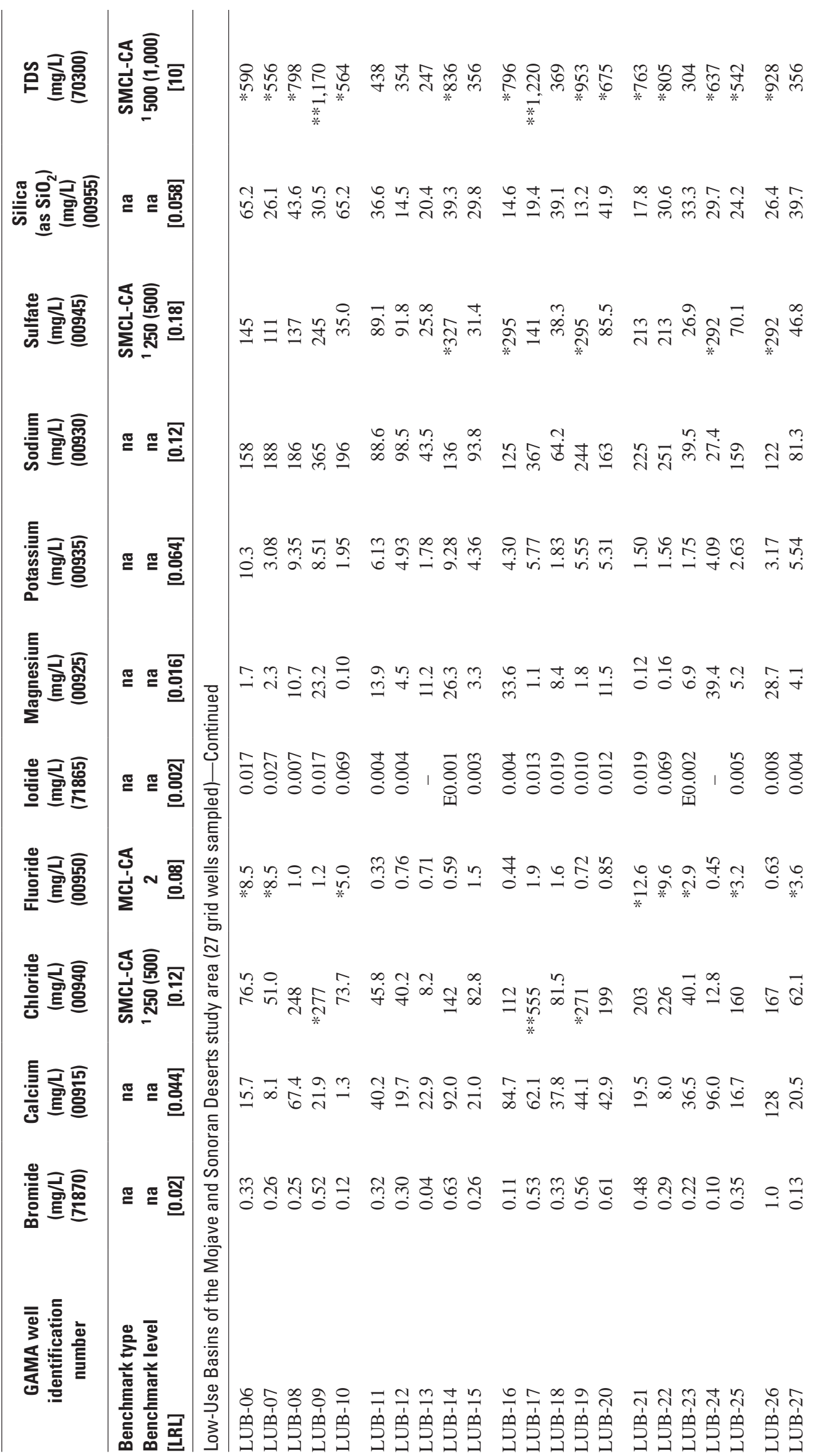




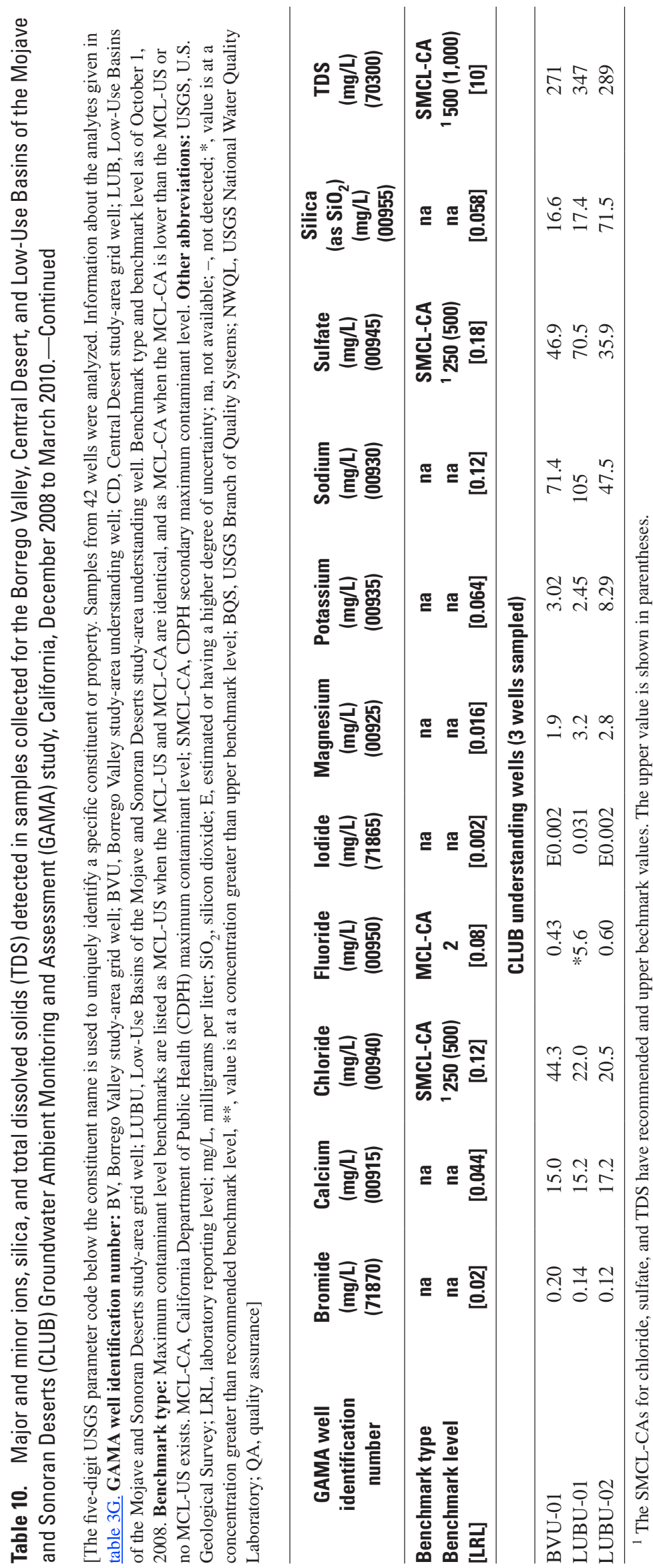


Table 11. Species of inorganic chromium detected in samples collected for the Borrego Valley, Central Desert, and Low-Use Basins of the Mojave and Sonoran Deserts (CLUB) Groundwater Ambient Monitoring and Assessment (GAMA) study, California, December 2008.

[D ata in this table was generated at the USGS Trace M etals L aboratory, B oulder, Colorado, using research methods and are not stored in the USGS $N$ ational Water Information System database. Information about the analytes given in table 3H. Samples from 7 slow wells in December 2008 were analyzed. GAMA well identification number: $C D, C$ entral Desert studyarea grid well; LUB, Low-U se Basins of the M ojave and Sonoran Deserts study-area grid well. M ethod detection limit, benchmark type, and benchmark level as of October 1, 2008. Benchmark type: M aximum contaminant level benchmarks are listed as M CL-US when the M CL-US and M CL-CA are identical, and as MCL-CA when the MCL-CA is lower than the MCL-US or no M CL-US exists. M CL-CA, California Department of Public Health maximum contaminant level. Other abbreviations: USGS, U.S. Geological Survey; Cr-VI, hexavalent chromium, chromium-VI; M DL, method detection limit; $\mu \mathrm{g} / \mathrm{L}$, micrograms per liter; na, not available; $E$, estimated or having a high degree of uncertianty; - , not detected]

\begin{tabular}{|c|c|c|}
\hline $\begin{array}{c}\text { GAMA well } \\
\text { identification } \\
\text { number }\end{array}$ & $\begin{array}{l}\text { Chromium } \\
(\mu \mathrm{g} / \mathrm{L})\end{array}$ & $\begin{array}{l}\text { Cr-VI } \\
(\mu \mathrm{g} / \mathrm{L})\end{array}$ \\
\hline Benchmark type & MCL-CA & na \\
\hline Benchmark level & 50 & na \\
\hline [MDL] & [1] & [1] \\
\hline \multicolumn{3}{|c|}{ CLUB grid wells (7 wells sampled) } \\
\hline \multicolumn{3}{|c|}{ Borrego Valley study area (3 grid wells sampled) } \\
\hline CD-01 & 3.0 & 2.3 \\
\hline CD -03 & E0.6 & E0.5 \\
\hline CD -04 & E0.6 & E0.6 \\
\hline \multicolumn{3}{|c|}{$\begin{array}{l}\text { Low-Use Basins of the Mojave and Sonoran Deserts study area } \\
\text { ( } 4 \text { grid wells sampled) }\end{array}$} \\
\hline LUB-01 & 6.4 & 5.3 \\
\hline LUB -03 & - & - \\
\hline LUB -07 & 2.1 & 1.9 \\
\hline LUB-10 & - & - \\
\hline
\end{tabular}

Table 12. Hexavalent chromium (chromium-VI, Cr-VI) detected in samples collected for the Borrego Valley, Central Desert, and Low-Use Basins of the Mojave and Sonoran Deserts (CLUB) Groundwater Ambient Monitoring and Assessment (GAMA) study, California, October 2009 to March 2010.

[The five-digit USGS parameter code below the constituent name is used to uniquely identify a specific constituent or property. Data in this table were generated at TestA merica L aboratories, Inc., Irvine, California. Samples from 17 slow wells were analyzed. Information about the analyte given in table 31. GAMA well identification number: BV, B orrego Valley study-area grid well; BVU, Borrego Valley study-area understanding well; CD, Central Desert study-area grid well; LUB, L ow$U$ se Basins of the M ojave and Sonoran Deserts study-area grid well. $M$ ethod detection limit as of October 5, 2009. Other abbreviations: USGS, U.S. Geological Survey; na, not available; M DL, method detection limit; $\mu \mathrm{g} / \mathrm{L}$, micrograms per liter; - , not detected]

\begin{tabular}{|c|c|}
\hline $\begin{array}{c}\text { GAMA well } \\
\text { identification } \\
\text { number }\end{array}$ & $\begin{array}{l}\text { Cr-VI } \\
(\mu \mathrm{g} / \mathrm{L})\end{array}$ \\
\hline Benchmark type & na \\
\hline Benchmark level & na \\
\hline [MDL] & [1] \\
\hline \multicolumn{2}{|c|}{ CLUB grid wells (16 wells sampled) } \\
\hline \multicolumn{2}{|c|}{ Borrego Valley study area (3 grid wells sampled) } \\
\hline BV-01 & 3.0 \\
\hline BV-03 & E0.6 \\
\hline BV-04 & E0.6 \\
\hline \multicolumn{2}{|c|}{ Central Desert study area (6 grid wells sampled) } \\
\hline CD -07 & 18.0 \\
\hline CD -09 & 1.9 \\
\hline CD-11 & - \\
\hline CD -12 & - \\
\hline CD -13 & 10.0 \\
\hline $\mathrm{CD}-14$ & 2.4 \\
\hline \multicolumn{2}{|c|}{$\begin{array}{l}\text { Low-Use Basins of the Mojave and Sonoran Deserts study area } \\
\text { (7 grid wells sampled) }\end{array}$} \\
\hline LUB-13 & 3.1 \\
\hline LUB-18 & - \\
\hline LUB-19 & - \\
\hline LUB-20 & 2.8 \\
\hline LUB -23 & - \\
\hline LUB-26 & - \\
\hline LUB -27 & 13.0 \\
\hline \multicolumn{2}{|c|}{ CLUB understanding wells (1 well sampled) } \\
\hline BVU -01 & 1.1 \\
\hline
\end{tabular}


Table 13. Results for analyses of stable isotope ratios, tritium activity, and carbon-14 abundance detected in samples collected for the Borrego Valley, Central Desert, and Low-Use Basins of the Mojave and Sonoran Deserts (CLUB) Groundwater Ambient Monitoring and Assessment (GAMA) study, California, December 2008 to March 2010.

[The five-digit USGS parameter code below the constituent name is used to uniquely identify a specific constituent or property. Information about the analytes given in table 3l. Samples from all 52 wells were analyzed for stable isotopes of hydrogen and oxygen in water and tritium activities. Samples from 51 wells were analyzed for stable isotopes of carbon in dissolved inorganic carbon and carbon-14 abundance. Stable isotope ratios are reported in the standard delta notation ( $\delta$ ), the ratio of a heavier isotope to more common lighter isotope of that element, relative to a standard reference material. Tritium values less than the sample-specific critical level $\left(\mathrm{ssL}_{C}\right)$ are reported as non-detections (-). GAMA well identification number: BV, Borrego Valley study-area grid well; BVU, B orrego Valley study-area understanding well; CD, Central Desert study-area grid well; LUB, Low-U se Basins of the M ojave and Sonoran Deserts study-area grid well; LUBU, Low-U se B asins of the M ojave and Sonoran Deserts studyarea understanding well. B enchmark type and benchmark level as of O ctober 1, 2008. Benchmark type: M aximum contaminant level benchmarks are listed as M CL-US when the M CL-US and M CL-CA are identical, and as M CL-CA when the M CL-CA is lower than the M CL-US or no M CL-US exists. M CL-CA, California Department of Public Health maximum contaminant level. Other abbreviations: USGS, U.S. Geological Survey; $\mathrm{H}$, hydrogen; $\mathrm{O}$, oxygen; $\mathrm{C}$, carbon; CSU, 1-sigma combined standard uncertainty; pCi/L, picocuries per liter; -, not detected; \pm , plus or minus; na, not available]

\begin{tabular}{|c|c|c|c|c|c|c|}
\hline $\begin{array}{c}\text { GAMA well } \\
\text { identification } \\
\text { number }\end{array}$ & $\begin{array}{c}\delta^{2} \mathrm{H} \\
\text { (per mil) } \\
(82082)\end{array}$ & $\begin{array}{c}\delta^{18} 0 \\
\text { (per mil) } \\
(82085)\end{array}$ & \multicolumn{2}{|c|}{$\begin{array}{l}\text { Tritium } \\
\text { (pCi/L) } \\
(07000)\end{array}$} & $\begin{array}{c}\delta^{13} \mathrm{C} \\
\text { (per mil) } \\
(82081)\end{array}$ & $\begin{array}{c}\text { Carbon-14 } \\
\text { (percent } \\
\text { modern) } \\
(49933)\end{array}$ \\
\hline Benchmark type & na & na & \multicolumn{2}{|c|}{ MCL-CA } & na & na \\
\hline Benchmark level & na & na & \multicolumn{2}{|c|}{20,000} & na & na \\
\hline & & & Result \pm CSU & ssL $_{\mathbf{c}}$ & & \\
\hline \multicolumn{7}{|c|}{ CLUB grid wells (49 wells sampled) } \\
\hline \multicolumn{7}{|c|}{ Borrego Valley study area (7 grid wells sampled) } \\
\hline $\begin{array}{l}\text { BV }-01 \\
B V-02 \\
B V-03 \\
B V-04 \\
B V-05\end{array}$ & $\begin{array}{l}-56.90 \\
-56.40 \\
-60.90 \\
-64.00 \\
-59.90\end{array}$ & $\begin{array}{l}-8.17 \\
-8.34 \\
-8.73 \\
-8.90 \\
-8.83\end{array}$ & $\begin{array}{c}0.4 \pm 0.32 \\
3.8 \pm 0.35 \\
2.5 \pm 0.32 \\
- \\
0.5 \pm 0.32\end{array}$ & $\begin{array}{l}0.32 \\
0.32 \\
0.32 \\
0.32 \\
0.32\end{array}$ & $\begin{array}{r}-9.48 \\
-10.64 \\
-13.10 \\
-12.78 \\
-11.30\end{array}$ & $\begin{array}{c}42.41 \\
112.6 \\
99.29 \\
79.08 \\
27.45\end{array}$ \\
\hline $\begin{array}{l}B V-06 \\
B V-07\end{array}$ & $\begin{array}{l}-73.10 \\
-67.30\end{array}$ & $\begin{array}{l}-8.57 \\
-9.45\end{array}$ & - & $\begin{array}{l}0.32 \\
0.35\end{array}$ & $\begin{array}{r}-10.94 \\
\text { na }^{1}\end{array}$ & $\begin{array}{l}4.390 \\
\text { na }^{1}\end{array}$ \\
\hline \multicolumn{7}{|c|}{ Central Desert study area ( 15 grid wells sampled) } \\
\hline $\begin{array}{l}C D-01 \\
C D-02 \\
C D-03 \\
C D-04 \\
C D-05\end{array}$ & $\begin{array}{l}-83.80 \\
-82.30 \\
-78.70 \\
-80.60 \\
-81.60\end{array}$ & $\begin{array}{l}-11.4 \\
-11.0 \\
-11.1 \\
-11.5 \\
-11.5\end{array}$ & $\begin{array}{c}- \\
- \\
4.5 \pm 0.38 \\
2.8 \pm 0.45 \\
0.5 \pm 0.45\end{array}$ & $\begin{array}{l}0.35 \\
0.45 \\
0.35 \\
0.41 \\
0.45\end{array}$ & $\begin{array}{r}-8.81 \\
-9.44 \\
-12.13 \\
-12.40 \\
-11.85\end{array}$ & $\begin{array}{l}85.11 \\
84.73 \\
75.81 \\
87.65 \\
79.42\end{array}$ \\
\hline $\begin{array}{l}C D-06 \\
C D-07 \\
C D-08 \\
C D-09 \\
C D-10\end{array}$ & $\begin{array}{l}-78.70 \\
-77.80 \\
-89.50 \\
-73.90 \\
-80.50\end{array}$ & $\begin{array}{c}-11.1 \\
-11.0 \\
-11.9 \\
-9.98 \\
-11.2\end{array}$ & $\begin{array}{c}4.4 \pm 0.45 \\
- \\
0.5 \pm 0.32 \\
6.9 \pm 0.41 \\
2.5 \pm 0.35\end{array}$ & $\begin{array}{l}0.38 \\
0.32 \\
0.32 \\
0.32 \\
0.32\end{array}$ & $\begin{array}{r}-10.50 \\
-11.10 \\
-10.03 \\
-10.92 \\
-9.99\end{array}$ & $\begin{array}{l}92.91 \\
59.77 \\
12.69 \\
91.04 \\
90.55\end{array}$ \\
\hline $\begin{array}{l}C D-11 \\
C D-12 \\
C D-13 \\
C D-14 \\
C D-15\end{array}$ & $\begin{array}{l}-73.50 \\
-77.00 \\
-83.40 \\
-83.10 \\
-82.20\end{array}$ & $\begin{array}{l}-10.6 \\
-10.7 \\
-11.3 \\
-11.3 \\
-11.3\end{array}$ & $\begin{array}{c}4.6 \pm 0.41 \\
- \\
- \\
- \\
-\end{array}$ & $\begin{array}{l}0.35 \\
0.32 \\
0.32 \\
0.32 \\
0.32\end{array}$ & $\begin{array}{r}-12.27 \\
-12.21 \\
-9.59 \\
-11.03 \\
-8.52\end{array}$ & $\begin{array}{c}107.1 \\
26.62 \\
31.86 \\
26.31 \\
54.81\end{array}$ \\
\hline \multicolumn{7}{|c|}{ Low-Use Basins of the Mojave and Sonoran Deserts study area (27 grid wells sampled) } \\
\hline $\begin{array}{l}\text { LUB-01 } \\
\text { LUB-02 } \\
\text { LUB-03 } \\
\text { LUB-04 } \\
\text { LUB-05 }\end{array}$ & $\begin{array}{l}-69.00 \\
-78.30 \\
-82.70 \\
-78.50 \\
-88.50\end{array}$ & $\begin{array}{l}-8.67 \\
-10.9 \\
-11.1 \\
-10.9 \\
-11.9\end{array}$ & $\begin{array}{c}2.7 \pm 0.38 \\
- \\
0.7 \pm 0.38 \\
- \\
-\end{array}$ & $\begin{array}{l}0.35 \\
0.35 \\
0.38 \\
0.38 \\
0.38\end{array}$ & $\begin{array}{r}-9.23 \\
-6.74 \\
-11.66 \\
-6.82 \\
-9.24\end{array}$ & $\begin{array}{l}45.07 \\
21.29 \\
50.48 \\
19.27 \\
60.23\end{array}$ \\
\hline
\end{tabular}


Table 13. Results for analyses of stable isotope ratios, tritium activity, and carbon-14 abundance detected in samples collected for the Borrego Valley, Central Desert, and Low-Use Basins of the Mojave and Sonoran Deserts (CLUB) Groundwater Ambient Monitoring and Assessment (GAMA) study, California, December 2008 to March 2010.-Continued

[The five-digit USGS parameter code below the constituent name is used to uniquely identify a specific constituent or property. Information about the analytes given in table 3l. Samples from all 52 wells were analyzed for stable isotopes of hydrogen and oxygen in water and tritium activities. Samples from 51 wells were analyzed for stable isotopes of carbon in dissolved inorganic carbon and carbon-14 abundance. Stable isotope ratios are reported in the standard delta notation $(\delta)$, the ratio of a heavier isotope to more common lighter isotope of that element, relative to a standard reference material. Tritium values less than the sample-specific critical level ( $\left.\mathrm{ssL}_{c}\right)$ are reported as non-detections (-). GAMA well identification number: BV, B orrego Valley study-area grid well; BV U, B orrego Valley study-area understanding well; CD, Central D esert study-area grid well; LU B, L ow-U se B asins of the M ojave and Sonoran Deserts study-area grid well; LUBU, Low-U se Basins of the M ojave and Sonoran Deserts studyarea understanding well. B enchmark type and benchmark level as of October 1, 2008. Benchmark type: M aximum contaminant level benchmarks are listed as M CL-US when the M CL-US and M CL-CA are identical, and as M CL-CA when the M CL-CA is lower than the M CL-US or no M CL-US exists. MCL-CA, California Department of Public Health maximum contaminant level. Other abbreviations: USGS, U.S. Geological Survey; $\mathrm{H}$, hydrogen; $\mathrm{O}$, oxygen; $\mathrm{C}$, carbon; CSU, 1-sigma combined standard uncertainty; pCi/L, picocuries per liter; -, not detected; \pm , plus or minus; na, not available]

\begin{tabular}{|c|c|c|c|c|c|c|}
\hline $\begin{array}{c}\text { GAMA well } \\
\text { identification } \\
\text { number }\end{array}$ & $\begin{array}{c}\delta^{2} \mathrm{H} \\
\text { (per mil) } \\
(\mathbf{8 2 0 8 2})\end{array}$ & $\begin{array}{c}\delta^{18} 0 \\
\text { (per mil) } \\
(82085)\end{array}$ & \multicolumn{2}{|c|}{$\begin{array}{l}\text { Tritium } \\
\text { (pCi/L) } \\
\text { (07000) }\end{array}$} & $\begin{array}{c}\delta^{13} \mathrm{C} \\
\text { (per mil) } \\
(82081)\end{array}$ & $\begin{array}{c}\text { Carbon-14 } \\
\text { (percent } \\
\text { modern) } \\
\text { (49933) }\end{array}$ \\
\hline Benchmark type & na & na & \multicolumn{2}{|c|}{ MCL-CA } & na & na \\
\hline Benchmark level & na & na & \multicolumn{2}{|c|}{20,000} & na & na \\
\hline & & & Result \pm CSU & ssL $_{c}$ & & \\
\hline \multicolumn{7}{|c|}{ Low-Use Basins of the Mojave and Sonoran Deserts study area (27 grid wells sampled)_Continued } \\
\hline LUB-06 & -93.40 & -11.4 & $0.5 \pm 0.38$ & 0.35 & -8.64 & 22.24 \\
\hline LUB-07 & -95.90 & -11.9 & - & 0.35 & -5.82 & 6.020 \\
\hline LUB-08 & -97.50 & -12.4 & - & 0.35 & -8.31 & 8.220 \\
\hline LUB-09 & -85.90 & -10.6 & - & 0.38 & -3.27 & 22.04 \\
\hline LUB-10 & -69.10 & -9.49 & - & 0.35 & -7.30 & 14.51 \\
\hline LUB-11 & -102.0 & -13.1 & - & 0.35 & -9.33 & 6.820 \\
\hline LUB-12 & -90.20 & -11.9 & - & 0.35 & -9.97 & 25.31 \\
\hline LUB-13 & -89.70 & -12.4 & - & 0.32 & -8.85 & 15.90 \\
\hline LUB-14 & -65.00 & -9.17 & - & 0.32 & -12.80 & 56.20 \\
\hline LUB-15 & -73.10 & -10.2 & - & 0.32 & -10.13 & 31.76 \\
\hline LUB-16 & -94.30 & -11.4 & $17.8 \pm 0.67$ & 0.32 & -7.89 & 89.60 \\
\hline LUB-17 & -54.40 & -7.26 & - & 0.32 & -8.52 & 9.440 \\
\hline LUB-18 & -57.30 & -8.27 & $1.2 \pm 0.32$ & 0.32 & -14.97 & 89.61 \\
\hline LUB-19 & -67.50 & -8.55 & - & 0.32 & -10.30 & 30.84 \\
\hline LUB-20 & -73.00 & -10.2 & - & 0.32 & -10.41 & 34.20 \\
\hline LUB-21 & -79.80 & -10.6 & - & 0.32 & -10.07 & 14.74 \\
\hline LUB-22 & -73.70 & -9.69 & - & 0.32 & -5.43 & 3.040 \\
\hline LUB-23 & -70.80 & -9.78 & $0.3 \pm 0.35$ & 0.35 & -9.88 & 53.99 \\
\hline LUB-24 & -88.00 & -12.1 & $0.6 \pm 0.35$ & 0.35 & -6.46 & 4.230 \\
\hline LUB-25 & -79.50 & -10.5 & $0.6 \pm 0.32$ & 0.32 & -8.11 & 9.790 \\
\hline LUB-26 & -75.20 & -10.1 & $3.9 \pm 0.41$ & 0.35 & -8.98 & 99.20 \\
\hline LUB-27 & -83.70 & -11.4 & - & 0.35 & -8.37 & 10.44 \\
\hline \multicolumn{7}{|c|}{ CLUB understanding wells ( 3 wells sampled) } \\
\hline BVU-01 & -70.40 & -9.73 & - & 0.32 & -11.27 & 18.51 \\
\hline LUBU-01 & -79.40 & -11.1 & - & 0.38 & -10.33 & 38.49 \\
\hline LUBU-02 & -98.30 & -12.7 & - & 0.35 & -9.48 & 18.50 \\
\hline
\end{tabular}

\footnotetext{
${ }^{1}$ Sample bottle broken during shipment to the laboratory.
} 
Table 14A. Radon-222 detected in samples collected for the Borrego Valley, Central Desert, and Low-Use Basins of the Mojave and Sonoran Deserts (CLUB) Groundwater Ambient Monitoring and Assessment (GAMA) study, California, December 2008 to March 2010.

[The five-digit USGS parameter code below the constituent name is used to uniquely identify a specific constituent or property. Samples from 23 slow wells were analyzed. Information about the analytes given in table 3]. GAMA well identification number: BV, Borrego Valley study-area grid well; BV U, B orrego Valley study-area understanding well; CD, Central Desert study-area grid well; LUB, Low-U se B asins of the M ojave and Sonoran Deserts study-area grid well. B enchmark type and benchmark level as of October 1, 2008. Benchmark type: M aximum contaminant level benchmarks are listed as M CL-US when the MCL-US and MCL-CA are identical, and as M CL-CA when the M CL-CA is lower than the M CL-US or no M CL-US exists. M CL-US, U.S. Environmental Protection A gency maximum contaminant level. Other abbreviations: USGS, U.S. Geological Survey; CSU, combined standard uncertainty; pCi/L, picocuries per liter; $s s L_{C}$, sample-specific critical level; \pm , plus or minus]

\begin{tabular}{|c|c|c|}
\hline \multirow{2}{*}{$\begin{array}{c}\text { GAMA well } \\
\text { identification } \\
\text { number }\end{array}$} & \multicolumn{2}{|c|}{$\begin{array}{c}\text { Radon-222 } \\
\text { (pCi/L) } \\
(82303)\end{array}$} \\
\hline & Result \pm CSU & $\operatorname{ssL}_{\mathrm{C}}$ \\
\hline Benchmark type & \multicolumn{2}{|c|}{ Proposed MCL-US } \\
\hline Benchmark level & \multicolumn{2}{|c|}{4,000} \\
\hline
\end{tabular}

CLUB Grid wells (22 wells sampled) ${ }^{1}$

\begin{tabular}{lcl}
\hline \multicolumn{3}{l}{ Borrego Valley study area (3 grid wells sampled) } \\
\hline BV-03 & $390 \pm 26$ & 13 \\
BV-04 & $175 \pm 15$ & 13 \\
BV-07 & $600 \pm 36$ & 12 \\
\hline Central Desert study area (8 grid wells sampled) & \\
\hline CD -01 & $630 \pm 38$ & 12 \\
CD-03 & $1,090 \pm 61$ & 10 \\
CD-04 & $1,700 \pm 95$ & 12 \\
CD -07 & $510 \pm 32$ & 12 \\
CD -09 & $1,080 \pm 61$ & 11 \\
CD-11 & $810 \pm 47$ & 11 \\
CD-12 & $810 \pm 47$ & 13 \\
CD-14 & $670 \pm 40$ & 12 \\
\hline
\end{tabular}

\begin{tabular}{|c|c|c|}
\hline \multirow{2}{*}{$\begin{array}{c}\text { GAMA well } \\
\text { identification } \\
\text { number }\end{array}$} & \multicolumn{2}{|c|}{$\begin{array}{c}\text { Radon-222 } \\
\text { (pCi/L) } \\
(82303)\end{array}$} \\
\hline & Result \pm CSU & ssL $_{\mathrm{C}}$ \\
\hline Benchmark type & \multicolumn{2}{|c|}{ Proposed MCL-US } \\
\hline Benchmark level & \multicolumn{2}{|c|}{4,000} \\
\hline
\end{tabular}

Low-Use Basins of the Mojave and Sonoran Deserts study area (11 grid wells sampled)

\begin{tabular}{lrc}
\hline LUB-01 & $400 \pm 26$ & 13 \\
LUB-03 & $570 \pm 35$ & 13 \\
LUB-07 & $830 \pm 48$ & 11 \\
LUB-10 & $1,540 \pm 86$ & 12 \\
LUB-13 & $660 \pm 39$ & 11 \\
LUB-18 & $240 \pm 19$ & 14 \\
LUB-19 & $270 \pm 20$ & 13 \\
LUB-20 & $340 \pm 22$ & 11 \\
LUB-23 & $1,400 \pm 79$ & 15 \\
LUB-26 & $760 \pm 45$ & 14 \\
LUB-27 & $490 \pm 30$ & 11 \\
\hline & CLUB understanding wells (1 well sampled) \\
\hline BVU-01 & $330 \pm 22$ & 12
\end{tabular}

\footnotetext{
${ }^{1}$ Sample from CD-13 was not collected.
} 
Table 14B. Radium isotopes detected in samples collected for the Borrego Valley, Central Desert, and Low-Use Basins of the Mojave and Sonoran Deserts (CLUB) Groundwater Ambient Monitoring and Assessment (GAMA) study, California, December 2008 to March 2010.

[The five-digit USGS parameter code below the constituent name is used to uniquely identify a specific constituent or property. Samples from the 24 slow wells were analyzed. Information about the analytes given in table 3|. Values less than the samplespecific critical level $\left(\mathrm{ssL}_{C}\right)$ are reported as non-detections. GAMA well identification number: BV, B orrego Valley study-area grid well; BVU, B orrego Valley study-area understanding well; CD, Central Desert study-area grid well; LUB, Low-U se Basins of the M ojave and Sonoran Deserts study-area grid well; LUBU, L ow-U se Basins of the M ojave and Sonoran Deserts study-area understanding well. B enchmark type and benchmark level as of October 1, 2008. Benchmark type: M aximum contaminant level benchmarks are listed as M CL-US when the M CL-US and M CL-CA are identical, and as M CL-CA when the M CL-CA is lower than the M CL-US or no M CL-US exists. M CL-US, U.S. Environmental Protection A gency maximum contaminant level. Other abbreviations: USGS, U.S. G eological Survey; CSU, combined standard uncertainty; pCi/L, picocuries per liter; \pm , plus or minus; - , not detected]

\begin{tabular}{|c|c|c|c|c|}
\hline \multirow{2}{*}{$\begin{array}{c}\text { GAMA well } \\
\text { identification } \\
\text { number }\end{array}$} & \multicolumn{2}{|c|}{$\begin{array}{c}\text { Radium-226 } \\
\text { (pCi/L) } \\
(09511)\end{array}$} & \multicolumn{2}{|c|}{$\begin{array}{c}\text { Radium-228 } \\
\text { (pCi/L) } \\
(81366)\end{array}$} \\
\hline & Result \pm CSU & $\mathbf{s s L}_{\mathbf{C}}$ & Result \pm CSU & ssL $_{c}$ \\
\hline Benchmark type & \multicolumn{2}{|c|}{ MCL-US } & \multicolumn{2}{|c|}{ MCL-US } \\
\hline Benchmark level & \multicolumn{2}{|c|}{15} & \multicolumn{2}{|c|}{15} \\
\hline \multicolumn{5}{|c|}{ CLUB grid wells (22 wells sampled) ${ }^{1}$} \\
\hline \multicolumn{5}{|c|}{ Borrego Valley study area (3 grid wells sampled) } \\
\hline BV-03 & $0.08 \pm 0.011$ & 0.013 & $0.55 \pm 0.085$ & 0.17 \\
\hline BV-04 & $0.07 \pm 0.015$ & 0.017 & - & 0.20 \\
\hline BV-07 & $0.036 \pm 0.011$ & 0.016 & $0.29 \pm 0.13$ & 0.20 \\
\hline \multicolumn{5}{|c|}{ Central Desert study area (8 grid wells sampled) } \\
\hline CD-01 & $0.048 \pm 0.013$ & 0.015 & $0.82 \pm 0.11$ & 0.22 \\
\hline CD-03 & $0.103 \pm 0.017$ & 0.014 & $0.48 \pm 0.098$ & 0.22 \\
\hline CD-04 & $0.097 \pm 0.016$ & 0.014 & - & 0.27 \\
\hline$C D-07$ & $0.068 \pm 0.011$ & 0.010 & - & 0.18 \\
\hline CD-09 & $0.188 \pm 0.021$ & 0.017 & $0.27 \pm 0.12$ & 0.24 \\
\hline CD-11 & $0.09 \pm 0.016$ & 0.016 & $0.57 \pm 0.12$ & 0.23 \\
\hline CD-12 & $0.035 \pm 0.012$ & 0.015 & - & 0.18 \\
\hline CD-13 & $0.0331 \pm 0.0084$ & 0.015 & - & 0.18 \\
\hline CD-14 & $0.05 \pm 0.01$ & 0.016 & - & 0.17 \\
\hline \multicolumn{5}{|c|}{ Low-Use Basins of the Mojave and Sonoran Deserts study area (11 grid wells sampled) } \\
\hline LUB-01 & $0.035 \pm 0.01$ & 0.014 & - & 0.20 \\
\hline LUB-03 & $0.114 \pm 0.016$ & 0.011 & $0.344 \pm 0.092$ & 0.21 \\
\hline LUB-07 & $0.04 \pm 0.013$ & 0.015 & - & 0.21 \\
\hline LUB-10 & $0.018 \pm 0.011$ & 0.015 & - & 0.22 \\
\hline LUB-13 & $0.067 \pm 0.015$ & 0.016 & - & 0.17 \\
\hline LUB-18 & $0.137 \pm 0.016$ & 0.014 & - & 0.20 \\
\hline LUB-19 & $0.058 \pm 0.011$ & 0.015 & $0.244 \pm 0.096$ & 0.22 \\
\hline LUB-20 & $0.085 \pm 0.016$ & 0.017 & - & 0.20 \\
\hline LUB-23 & $0.114 \pm 0.019$ & 0.016 & $0.78 \pm 0.14$ & 0.18 \\
\hline LUB-26 & $0.088 \pm 0.013$ & 0.013 & $0.355 \pm 0.077$ & 0.16 \\
\hline \multicolumn{5}{|c|}{ CLUB understanding wells (1 well sampled) } \\
\hline BVU-01 & $0.03 \pm 0.01$ & 0.015 & $0.26 \pm 0.13$ & 0.26 \\
\hline
\end{tabular}

1 The M CL-US benchmark for radium is the sum of radium-226 and radium- 228 . 
Table 14C. Gross alpha and beta radioactivity detected in samples collected for the Borrego Valley, Central Desert, and Low-Use Basins of the Mojave and Sonoran Deserts (CLUB) Groundwater Ambient Monitoring and Assessment (GAMA) study, California, December 2008 to March 2010.

[The five-digit USGS parameter code below the constituent name is used to uniquely identify a specific constituent or property. Samples from the 24 slow wells were analyzed. Information about the analytes given in table 3. . The reference nuclide for measurement of gross alpha is thorium-230, and the reference nuclide for measurement of gross beta is cesium-137. Measured values less than the sample-specific critical level ( $\mathrm{ssL}_{C}$ ) are reported as non-detections. GAMA well identification number: BV, B orrego Valley study-area grid well; BVU, B orrego Valley study-area understanding well; CD, Central Desert study-area grid well; LUB, L ow-U se B asins of the M ojave and Sonoran Deserts study-area grid well; LUBU, L ow-U se Basins of the M ojave and Sonoran Deserts study-area understanding well. B enchmark type and benchmark level as of October 1, 2008. Benchmark type: M aximum contaminant level benchmarks are listed as M CL-US when the MCL-US and M CL-CA are identical, and as M CL-CA when the M CL-CA is lower than the M CL-US or no M CL-US exists. M CL-US, U.S. Environmental Protection A gency maximum contaminant level. Other abbreviations: USGS, U.S. Geological Survey; CSU, 1-sigma combined standard uncertainty; pCi/L, picocuries per liter; -, not detected; \pm , plus or minus; *, value is at a concentration greater than benchmark level]

\begin{tabular}{|c|c|c|c|c|c|c|c|c|}
\hline \multirow[t]{2}{*}{$\begin{array}{c}\text { GAMA well } \\
\text { identification } \\
\text { number }\end{array}$} & \multicolumn{2}{|c|}{$\begin{array}{c}\text { Gross alpha } \\
\text { radioactivity, } \\
\text { 72-hour count } \\
\text { (pCi/L) } \\
(62636)\end{array}$} & \multicolumn{2}{|c|}{$\begin{array}{l}\text { Gross alpha } \\
\text { radioactivity, } \\
\text { 30-day count } \\
\text { (pCi/L) } \\
\text { (62639) }\end{array}$} & \multicolumn{2}{|c|}{$\begin{array}{l}\text { Gross beta } \\
\text { radioactivity, } \\
\text { 72-hour count } \\
\text { (pCi/L) } \\
\text { (62642) }\end{array}$} & \multicolumn{2}{|c|}{$\begin{array}{c}\text { Gross beta } \\
\text { radioactivity, } \\
\text { 30-day count } \\
\text { (pCi/L) } \\
(62645)\end{array}$} \\
\hline & Result \pm CSU & $\mathbf{s s L}_{\mathrm{c}}$ & Result \pm CSU & ssL $_{c}$ & Result \pm CSU & ssL $_{c}$ & Result \pm CSU & $\mathbf{s s L}_{\mathrm{c}}$ \\
\hline Benchmark type & \multicolumn{2}{|c|}{ MCL-US } & \multicolumn{2}{|c|}{ MCL-US } & \multicolumn{2}{|c|}{ MCL-CA } & \multicolumn{2}{|c|}{ MCL-CA } \\
\hline \multicolumn{9}{|c|}{ CLUB grid wells ( 23 wells sampled) } \\
\hline \multicolumn{9}{|c|}{ Borrego Valley study area (3 grid wells sampled) } \\
\hline BV -03 & $9.4 \pm 1.7$ & 1.2 & $6.3 \pm 1.5$ & 1.3 & ${ }^{1} 10.7 \pm 0.76$ & 0.51 & $21.4 \pm 1.4$ & 0.84 \\
\hline BV-04 & - & 1.4 & - & 1.2 & $5.8 \pm 0.72$ & 0.89 & $5.35 \pm 0.71$ & 0.91 \\
\hline BV-07 & $2.54 \pm 0.89$ & 0.97 & - & 0.94 & $2.61 \pm 0.57$ & 0.83 & $1.87 \pm 0.56$ & 0.83 \\
\hline CD -04 & $3.92 \pm 0.68$ & 0.46 & $4.33 \pm 0.75$ & 0.60 & $1.46 \pm 0.31$ & 0.43 & $2.19 \pm 0.46$ & 0.71 \\
\hline CD -07 & $7.0 \pm 1.0$ & 0.51 & $3.42 \pm 0.83$ & 0.62 & $2.85 \pm 0.38$ & 0.48 & $3.14 \pm 0.52$ & 0.68 \\
\hline CD -09 & $10.8 \pm 1.7$ & 1.4 & $3.5 \pm 1.2$ & 1.5 & $1.97 \pm 0.46$ & 0.66 & $3.75 \pm 0.51$ & 0.66 \\
\hline$C D-11$ & $* 28.7 \pm 3.7$ & 1.2 & $14.4 \pm 2.3$ & 1.4 & $8.32 \pm 0.68$ & 0.66 & $17.0 \pm 1.2$ & 0.86 \\
\hline CD-12 & $* 20.8 \pm 2.4$ & 0.36 & $* 21.0 \pm 2.5$ & 1.2 & $1.09 \pm 0.33$ & 0.46 & $6.09 \pm 0.51$ & 0.47 \\
\hline CD-13 & $10.5 \pm 1.4$ & 0.64 & $9.1 \pm 1.3$ & 0.60 & $3.17 \pm 0.48$ & 0.65 & $3.67 \pm 0.44$ & 0.52 \\
\hline CD-14 & $2.23 \pm 0.51$ & 0.43 & $2.23 \pm 0.51$ & 0.46 & $2.43 \pm 0.36$ & 0.48 & $2.74 \pm 0.34$ & 0.43 \\
\hline \multicolumn{9}{|c|}{ Low-Use Basins of the Mojave and Sonoran Deserts study area (11 grid wells sampled) } \\
\hline LUB-01 & - & 2.2 & - & 1.5 & $1.64 \pm 0.39$ & 0.58 & $2.09 \pm 0.50$ & 0.75 \\
\hline LUB-23 & $13.4 \pm 1.8$ & 0.55 & $4.9 \pm 0.9$ & 0.66 & $1.88 \pm 0.39$ & 0.54 & $2.68 \pm 0.41$ & 0.54 \\
\hline LUB-26 & $1 * 19.1 \pm 3.1$ & 1.9 & $13.7 \pm 2.6$ & 1.9 & ${ }^{1} 4.31 \pm 0.55$ & 0.68 & $7.41 \pm 0.68$ & 0.68 \\
\hline LUB-27 & $6.6 \pm 1.1$ & 0.54 & $5.6 \pm 0.99$ & 0.73 & $4.96 \pm 0.66$ & 0.87 & $5.5 \pm 0.58$ & 0.74 \\
\hline \multicolumn{9}{|c|}{ CLUB understanding wells (1 well sampled) } \\
\hline BVU-01 & $0.7 \pm 0.44$ & 0.59 & - & 1.3 & $2.67 \pm 0.42$ & 0.58 & $2.6 \pm 0.37$ & 0.49 \\
\hline
\end{tabular}

${ }^{1} 72$-hour holding time exceeded by 4 to 7 days. A delay in the counting by the laboratory may result in lower activities than may have been observed for these analytes if the count had been performed within the 72 -hour time period 


\section{Appendix}

This appendix includes discussions of the methods used to collect and analyze groundwater samples and to report the resulting water-quality data. These methods were selected to obtain representative samples of the groundwater from each well and to minimize the potential for contamination of the samples or bias in the data. Procedures used to collect and assess $Q C$ data, and the results of the $Q C$ assessments also are discussed.

In the CLUB study unit, groundwater samples were collected and QA/QC procedures were implemented by using standard and modified USGS protocols from the NAW QA Program (K oterba and others, 1995), the NFM (U.S. Geological Survey, variously dated), and protocols described by Shelton and others (2001) and Wright and others (2005). The QA plan followed by the NW Q L, the primary laboratory used to analyze samples for this study, is described in M aloney (2005) and Pirkey and Glodt (1998).

\section{Sample Collection and Analysis}

Prior to sampling, each well was pumped continuously to purge at least three casing-volumes of water from the well (Wilde and others, 1999). Wells were sampled using Teflon ${ }^{\circledR}$ tubing with brass and stainless-steel fittings attached to a sampling point on the well discharge pipe as close to the well head as possible. The sampling point was located upstream from water-storage tanks and upstream from the well-head treatment system (if a system existed). If a chlorinating system was attached to the well, the chlorinator was shut off, when possible, before the well was purged and sampled, in order to clear all chlorine out of the system. The absence of free chlorine was verified using a $\mathrm{Hach}^{\circledR}$ field test kit. For the fast schedule, samples were collected at the well head using a foot-long length of Teflon ${ }^{\circledR}$ tubing. For the slow schedule, the samples were either collected in the same manner as the fast schedule or collected inside an enclosed chamber located inside a mobile laboratory and connected to the well head by a $10-50 \mathrm{ft}$ length of the Teflon ${ }^{\circledR}$ tubing ( $L$ ane and others, 2003). All fittings and lengths of tubing were cleaned between samples (Wilde, 2004).

For the field measurements, groundwater was pumped through a flow-through chamber (that was attached to the sampling point) fitted with a multi-probe meter that simultaneously measures the field water-quality indicatorsdissolved oxygen, temperature, $\mathrm{pH}$, and specific conductance. Field measurements were made in accordance with protocols in the NFM (Radtke and others, 2005; Wilde and R adtke, 2005; Lewis, 2006; Wilde, 2006; Wilde and others, 2006). All sensors on the multi-probe meter were calibrated daily. $M$ easured temperature, dissolved oxygen, $\mathrm{pH}$, and specific-conductance values were recorded at 5-minute (min) intervals, and when these values remained stable for a minimum of $30 \mathrm{~min}$, samples for laboratory analyses then were collected.

Field measurements and instrument calibrations were recorded on field record sheets and electronically in the Personal Computer Field Form (PCFF) program. A nalytical service requests for the NW Q L were generated by PCFF, whereas analytical service requests for non-NW Q L analysis were entered into laboratory-specific spreadsheets. Information from PCFF was uploaded directly into the USGS NWIS database at the end of every week of sample collection.

Prior to sample collection, polyethylene sample bottles were pre-rinsed two times using deionized water, and then once with native sample water before sample collection. Samples requiring acidification were acidified to a $\mathrm{pH}$ of between 2 and 1 with the appropriate acids using ampoules of certified, traceable concentrated acids obtained from the NW Q L.

Temperature-sensitive samples were stored on ice prior to and during daily shipping to the various laboratories. The non-temperature sensitive samples for species of inorganic chromium, tritium, stable isotopes of hydrogen and oxygen in water, stable isotopes of boron and strontium in water, and dissolved noble gases were shipped monthly. Temperature- or time-sensitive samples for VOCS, pesticides and pesticide degradates, pharmaceutical compounds, perchlorate, NDM A, trace elements, nutrients, major and minor ions, silica, TDS, laboratory al kalinity, chromium-IV, radon-222, radium isotopes, and gross al pha and gross beta radioactivity were shipped daily. The temperature-sensitive samples for stable isotopes of carbon in dissolved inorganic carbon and carbon-14 abundance were stored on ice, archived in a laboratory refrigerator, and shipped after all of the alkalinity measurements were collected.

Detailed sampling protocols for individual analyses and groups of analytes are described in K oterba and others (1995), the NFM (Wilde and others, 1999, 2004), and in the references for analytical methods listed in table A 1; only brief descriptions are given here. V OC samples were collected in three 40-mL sample vials that were purged with three vial volumes of groundwater before bottom filling to eliminate atmospheric contamination. One to one (1:1) hydrochloric acid to water $\left(\mathrm{HCl} / \mathrm{H}_{2} \mathrm{O}\right)$ solution was added as a preservative to the VOC samples. Each sample to be analyzed for perchlorate was collected in a 125-milliliter ( $\mathrm{mL}$ ) polystyrene bottle and then filtered in two or three $20-\mathrm{mL}$ aliquots of groundwater through a 0.20 -micrometer $(\mu \mathrm{m})$ pore-size Corning ${ }^{\circledR}$ syringe-tip disk filter into a sterilized $125-\mathrm{mL}$ bottle. Tritium samples were collected by bottom filling one 1-L polyethylene bottle and one 1-L glass bottle with unfiltered groundwater, after first overfilling the bottles with three volumes of unfiltered 
groundwater. Samples for analysis of stable isotopes of hydrogen and oxygen in water were collected in a $60-\mathrm{mL}$ clear glass bottle filled with unfiltered groundwater, sealed with a conical cap, and secured with electrical tape to prevent leakage and evaporation.

Pesticides and pesticide degradates, pharmaceutical compounds, and NDM A samples were collected in 1-L baked amber glass bottles. Pesticide and pharmaceutical samples were filtered through a $0.7-\mu \mathrm{m}$ nominal pore-size glass fiber filter during collection, whereas the NDMA samples were filtered at Weck Laboratories, Inc., City of Industry, California, prior to analysis. NDM A sample containers, treated with $0.05 \mathrm{gram}(\mathrm{g})$ of sodium thiosulfate $\left(\mathrm{Na}_{2} \mathrm{~S}_{2} \mathrm{O}_{3}\right)$ as a preservative, were provided by Weck Laboratories, Inc.

Groundwater samples for trace elements, major and minor ions, silica, and TDS analyses required filling one 250 -mL polyethylene bottle with unfiltered groundwater and one $500-\mathrm{mL}$ and one $250-\mathrm{mL}$ polyethylene bottle with filtered groundwater (Wilde and others, 2004). Filtration was done using either a $0.45-\mu \mathrm{m}$ pore-size $W$ hatman ${ }^{\circledR}$ vented capsule filter or a $0.45-\mu \mathrm{m}$ pore-size PALL ${ }^{\circledR}$ unvented capsule filter that was pre-rinsed with $2-L$ of deionized water, then rinsed with 1-L of groundwater prior to sampling. The $250-\mathrm{mL}$ filtered sample then was preserved with 7.5-Normal $(\mathrm{N})$ nitric acid. Nutrient samples were collected by filtering groundwater into a 125-mL brown polyethylene bottle. Cr-VI samples for analysis at TALIR were collected by filtering groundwater into a 500- $\mathrm{mL}$ polyethylene bottle and buffering to a $\mathrm{pH}$ range of 9.3 to 9.7 with a solution consisting of ammonium sulfate, ammonium hydroxide, and ultrapure water. Stable isotopes of boron and strontium in water samples were filtered into one 250-mL polyethylene bottle and secured with electrical tape to prevent leakage and evaporation. Radium isotope and gross alpha and gross beta radioactivity samples were each filtered into individual $1-\mathrm{L}$ polyethylene bottles and then preserved with 7.5-N nitric acid. Stable isotopes of carbon in dissolved inorganic carbon and carbon-14 abundance samples were filtered and bottom filled into $500-\mathrm{mL}$ glass bottles that first were overfilled with three bottle volumes of groundwater. These samples had no headspace and were seal ed with conical caps to avoid atmospheric contamination. Samples for laboratory or field alkalinity titrations were collected by filtering groundwater into a $500-\mathrm{mL}$ polyethylene bottle.

Species of inorganic chromium, radon-222, and noble gases samples were collected from the hose bib at the well head, regardless of the sampling schedule (fast or slow).

Species of inorganic chromium samples for analysis at the N RP-TM L were collected using a 10-mL syringe with an attached $0.45-\mu \mathrm{m}$ pore-size MILLEX ${ }^{\circledR} \mathrm{HA}$ disk filter. After the syringe was rinsed thoroughly and filled with groundwater, $4 \mathrm{~mL}$ of sample water was forced through the disk filter; the next $2 \mathrm{~mL}$ of the groundwater was filtered slowly into a small centrifuge vial for analysis of total chromium. Cr-VI then was collected by attaching a small cation-exchange column to the syringe filter and, after conditioning the column with
$2 \mathrm{~mL}$ of sample water, an additional $2 \mathrm{~mL}$ of sample water was collected in a second centrifuge vial. B oth vials were preserved with 10 microliters $(\mu \mathrm{L})$ of $7.5-\mathrm{N}$ nitric acid (Ball and M cClesky, 2003a,b).

For the collection of radon-222 samples, a stainless-steel and Teflon ${ }^{\circledR}$ valve assembly was attached to the sampling port at the well head (Wilde and others, 2004). The valve was partially closed to create back pressure, and a $10-\mathrm{mL}$ groundwater sample was taken through a Teflon ${ }^{\circledR}$ septum on the valve assembly using a glass syringe affixed with a stainless-steel needle. The sample was then injected into a $25-\mathrm{mL}$ vial partially filled with a scintillation mixture (mineral oil) and shaken. The vial then was placed in an insulated cardboard tube to protect the sample during shipping.

Dissolved noble gases were collected in $3 / 8$-inch-diameter copper tubes using reinforced nylon tubing connected to the hose bib at the well head. Groundwater was flushed through the tubing to dislodge bubbles before the flow was restricted with a back pressure valve. Clamps on either side of the copper tube then were tightened, trapping a sample of groundwater for analyses of dissolved noble gases (Weiss, 1968).

Field alkalinity was measured in the mobile laboratory at the well site. Alkalinity was measured on filtered samples by Gran's titration method (Gran, 1952). Titration data were entered directly into PCFF, and the concentrations of bicarbonate $\left(\mathrm{HCO}_{3}{ }^{-}\right)$and carbonate $\left(\mathrm{CO}_{3}{ }^{2-}\right)$ automatically were calculated from the titration data using the advanced speciation method (http://or.water.usgs.gov/alk/methods.html) with $\mathrm{pK}_{1}=6.35, \mathrm{pK}_{2}=10.33$, and $\mathrm{pK}_{\mathrm{W}}=14$. Concentrations of $\mathrm{HCO}_{3}{ }^{-}$and $\mathrm{CO}_{3}{ }^{2-}$ also were calculated from the laboratory alkalinity and laboratory $\mathrm{pH}$ measurements.

$\mathrm{N}$ ine laboratories performed chemical analyses for this study (table A 1), although most of the analyses were performed at the NW QL or by laboratories contracted by the NW QL. The NWQL maintains a rigorous QA program (Pirkey and Glodt, 1998; M aloney, 2005). Laboratory QC samples, including method blanks, continuing calibration verification standards, standard reference samples, reagent spikes, external certified reference materials, and external blind proficiency samples are analyzed regularly. M ethod detection limits are tested continuously, and laboratory reporting levels are updated accordingly. NW Q L maintains the National Environmental L aboratory A ccreditation Program (NELAP) and other certifications (http://www.nelac-institute.org/accredlabs.php). In addition, the USGS B ranch of Quality Systems (BQS) maintains independent oversight of QA at the NW QL and laboratories contracted by the NW QL. The BQS also runs the National Field Quality A ssurance Program (NFQA) that includes annual testing of all USGS field personnel for proficiency in making field water-quality measurements (http://qadata.cr.usgs.gov/nfqa/). Results for analyses made at the NW Q L or by laboratories contracted by the NW QL are uploaded directly into the USGS NWIS database. Results of analyses made at other laboratories are compiled in a project 
database and uploaded from there into the USGS N WIS database. Some laboratory QC data are stored in the USGS NWIS database also.

\section{Data Reporting}

The following section gives details for the laboratory reporting conventions and the constituents that are determined by multiple methods or by multiple laboratories.

\section{Reporting Limits}

The NW Q L uses the $L R L$ as a benchmark for reporting analytical results. The $L R L$ is set to minimize the reporting of false negatives (not detecting a compound when it actually is present in a sample) to less than 1 percent (Childress and others, 1999). The NW Q L updates $L R L$ values regularly, and the values listed in this report were in effect during the period groundwater samples from the CLUB study unit were analyzed (December 2008 to $M$ arch 2010). LRL values for some constituents changed on 0 ctober 1, 2009; therefore, two $L R L S$ are reported (table $3 A, 3 B, 3 E-G$ ): the $L R L$ for samples collected before 0 ctober 1,2009 , and the $L R L$ for samples collected on or after $O$ ctober 1,2009 . The highest L RL is used for this report.

The $L R L$ usually is set at two times the long-term method detection level (LT-M DL). The LT-M DL is derived from the standard deviation of at least 24 method detection level (M DL) determinations made over an extended period of time. The MDL is the minimum concentration of a substance that can be measured and reported with 99 -percent confidence that the concentration is greater than zero (at the M DL there is less than 1 percent chance of a false positive). LT-M D L s continually are monitored and updated (C hildress and others, 1999; U.S. Environmental Protection A gency, 2002). Concentrations less than the LT-M DL are reported as non-detections with a dash (-) in the data tables.

Concentrations between the $L R L$ and the LT-M DL are reported as estimated concentrations (coded by the letter " $E$ " preceding the values in the tables and text). For informationrich methods, detections less than the LT-M DL have high certainty of detection, but the precise concentration is uncertain. These values are al so E-coded. Information-rich methods are those that utilize gas chromatography or high-performance liquid chromatography (HPLC) with mass spectrometry detection, such as those methods used to analyze VOCs and pesticides. Compounds are identified by presence of characteristic fragmentation patterns in their mass spectra in addition to being quantified by measurement of peak areas at their associated chromatographic retention times. E-coded values also may result from detections outside the range of calibration standards, from detections that did not meet all laboratory QC criteria, and from samples that were diluted prior to analysis (Childress and others, 1999).
Some constituents in this study are reported by using minimum reporting levels (M RLs) or method uncertainties (MU). The M RL is the smallest measurable concentration of a constituent that may be reliably reported using a given analytical method (Timme, 1995). The MU generally indicates the precision of a particular analytical measurement; it gives a range of values wherein the true value will be found.

Results for most constituents are presented using the $L R L, M D L$, or $M R L$ values provided by the analyzing laboratories. Results for some organic and inorganic constituents are presented using study reporting levels ( $S R L$ ) derived from assessment of data from $Q C$ samples associated with groundwater samples collected as part of the GAM A -PB P (see the appendix section titled "A ssessment of Blank Results and SRLs").

The methods used for analysis of radiochemical constituents (tritium, radon-222, radium isotopes, and gross al pha and gross beta radioactivity) measure activities by counting techniques (table A 1). The reporting limits for radiochemical constituents are based on sample-specific critical levels ( $s \mathrm{~L}_{c}$ ) (M cCurdy and others, 2008). The critical level is analogous to the LT-M DL used for reporting analytical results for organic and non-radioactive inorganic constituents. Here, the critical level is defined as the minimum measured activity that indicates a positive detection of the radionuclide in the sample with less than a 5-percent probability of a false positive detection. Sample-specific critical levels are used for radiochemical measurements because the critical level is sensitive to sample size and sample yield during analytical processing and is dependent on instrument background, on counting times for the sample and background, and on the characteristics of the instrument being used and the nuclide being measured. A $n s \mathrm{~L}_{c}$ is calculated for each sample, and the measured activity in the sample is compared to the $\mathrm{SSL}_{C}$ associated with that sample. M easured activities less than the $s s \mathrm{~L}_{C}$ are reported as non-detections with a dash (-) in the data tables.

The analytical uncertainties associated with measurement of activities also are sensitive to sample-specific parameters, including sample size, sample yield during analytical processing, and time elapsed between sample collection and various steps in the analytical procedure, as well as parameters associated with the instrumentation. Therefore, measured activities of radioactive constituents are reported with sample-specific combined standard uncertainties (CSU). The CSU is reported at the 68-percent confidence level (1-sigma).

\section{Notation}

Stable isotopic compositions of oxygen, boron, carbon, and hydrogen are reported as relative isotope ratios in units of per mil using the standard delta notation (Coplen and others, 2002): 


$$
\delta^{i} \mathrm{E}=\left[\frac{\mathrm{R}_{\text {sample }}}{\mathrm{R}_{\text {reference }}}-1\right] \times 1,000 \text { per mil, }
$$

where

$i$ is the atomic mass of the heavier isotope of the element,

$E$ is the element ( $O$ for oxygen, $B$ for boron, $\mathrm{C}$ for carbon, $\mathrm{H}$ for hydrogen), $\mathrm{R}_{\text {sample }}$ is the ratio of the abundance of the heavier isotope of the element $\left({ }^{18} \mathrm{O},{ }^{11} \mathrm{~B},{ }^{13} \mathrm{C}\right.$, ${ }^{2} \mathrm{H}$ ) to the lighter isotope of the element $\left({ }^{16} \mathrm{O},{ }^{10} \mathrm{~B},{ }^{12} \mathrm{C},{ }^{1} \mathrm{H}\right)$ in the sample, and $R_{\text {reference }}$ is the ratio of the abundance of the heavier isotope of the element to the lighter isotope of the element in the reference material.

The reference material for oxygen and hydrogen is Vienna Standard M ean Ocean Water (V SM OW), which is assigned $\delta^{18} \mathrm{O}$ and $\delta^{2} \mathrm{H}$ values of 0 per mil (note than $\delta^{2} \mathrm{H}$ is sometimes written as $\delta \mathrm{D}$ because the common name of the heavier isotope of hydrogen, hydrogen-2, is deuterium) (Coplen and others, 2002). The reference material for boron is the National Institute of Standards and Technology (NIST) reference material SRM 951 boric acid, which is assigned a $\delta^{11} \mathrm{~B}$ value of 0 per mil. The reference material for carbon is Vienna Pee Dee Belemnite (VPDB), which is assigned a $\delta^{13} \mathrm{C}$ value of 0 per mil (Coplen and others, 2002). Positive values indicate enrichment of the heavier isotope, and negative values indicate depletion of the heavier isotope, compared to the ratios observed in the standard reference material.

Stable isotopic composition of strontium is presented as the abundance of atoms of the heavier isotope $\left({ }^{87} \mathrm{Sr}\right)$ to the lighter isotope $\left({ }^{86} \mathrm{Sr}\right.$ ) of the element.

\section{Constituents on Multiple Analytical Schedules}

Six constituents targeted in this study were measured by more than one analytical method or by more than one laboratory (table A 2). The preferred methods for these constituents were selected on the basis of the procedure recommended by the NW Q L (http://wwwnwal.cr.usgs.gov/ dyn.shtml?Preferred method selection procedure).

The water-quality indicators - alkalinity, $\mathrm{pH}$, and specific conductance - were measured in the field and at the NWQL. The field measurements are the preferred method for all three constituents; however, both measurements are reported on table 4. Field values are generally preferred because field conditions are considered more representative of groundwater conditions (Hem, 1985).

For total chromium concentrations, the approved method (Schedule 1948, which is used by the NW QL) is preferred over the research methods used by the NRP-TM L; however, both measurements are reported (tables 8 and 11). The concentrations measured by the NR P-TM L only are used to calculate ratios of the abundance of the oxidized species to the abundance of the reduced species for the element.

For example,

$$
\frac{\mathrm{Cr}(\mathrm{III})}{\mathrm{Cr}(\mathrm{VI})}=\frac{\mathrm{Cr}(\mathrm{T})-\mathrm{Cr}(\mathrm{VI})}{\mathrm{Cr}(\mathrm{VI})},
$$

where

$\mathrm{Cr}(\mathrm{T})$ is the total chromium concentration (measured),

$\mathrm{Cr}(\mathrm{VI})$ is the concentration of hexavalent chromium (measured), and

$\mathrm{Cr}(\mathrm{III})$ is the concentration of trivalent chromium (calculated).

Cr-VI was measured at two laboratories-NRP-TML and TALIR - and both sets of results are reported.

A dditionally, tritium was measured at two laboratories: LLN L and USGS Stable Isotope and Tritium L aboratory, M enlo Park, California (SITL). Only tritium data from the SITL was available for reporting at the time of this publication.

\section{Quality-Assurance Methods}

The purpose of QA is to identify which data best represent environmental conditions and which may have been affected by contamination or bias during sample collection, processing, storage, transportation, and (or) laboratory analysis. Four types of $Q C$ tests were used in this study: (1) blank samples were collected to assess positive bias as a result of contamination during sample handling or analysis, (2) replicate samples were collected to assess variability, (3) matrix-spike tests were done to assess positive or negative bias, and (4) surrogate compounds were added to samples analyzed for organic constituents to assess bias of laboratory analytical methods. Results that were found to have significant contamination bias, on the basis of the $\mathrm{QC}$ data collected from this study and previous studies, were flagged with an appropriate remark code (described in subsequent sections) and rejected from subsequent use, including calculations of detection frequency.

\section{Blanks}

The primary purposes of collecting blanks are to evaluate the magnitude of potential contamination of samples with compounds of interest during sample collection, processing, transport, and (or) analysis, and to identify and mitigate these sources of sample contamination. 


\section{Blank Collection and Analysis}

Field blanks were collected using blank water certified by the NWQL to contain less than the $L R L, M D L$, or MRL of the analytes investigated in the study (http://wwwnwql.cr.usgs. gov/USGS/O BW/obw.html). Nitrogen-purged, organic-free blank water was used for field blanks of organic constituents, and inorganic-free blank water was used for field blanks of other constituents.

Field blanks were analyzed for $\mathrm{V} O \mathrm{Cs}$, pesticides and pesticide degradates, perchlorate, NDM A, trace el ements, nutrients, major and minor ions, silica, TDS, species of inorganic chromium, radium isotopes, and gross alpha and gross beta radioactivity. Field blanks were not collected for tritium or dissolved noble gases. Tritium and dissolved noble gases are in the atmosphere and would dissolve into any solution used in collecting a blank, making it impractical to collect a blank for these analytes. Stable-isotopic ratios of boron, carbon, hydrogen, oxygen, and strontium are an intrinsic property of any of these elements; therefore, the concept of a blank does not apply to these ratios.

To collect field blanks, blank water either was pumped or poured through the sampling equipment (fittings and tubing) used to collect groundwater samples, then processed and transported using the same protocols as were used for the groundwater samples. Twelve liters of blank water were pumped or poured through the sampling equipment before each field blank was collected.

\section{Assessment of Blank Results and SRLs}

Contamination in blanks may originate from several different types of sources that require different strategies for assessment of potential contamination of groundwater samples during sample collection, handling, and analysis. Four primary modes of contamination are assessed in the event of detections in blanks or atypical results in groundwater samples: (1) impurities in the water used to collect the blanks, (2) contamination during sample collection and handling from a known source or condition present at the field site, (3) carry-over of material on the sampling equipment from one sample to the next sample, (4) systematic and random contamination from field and laboratory equipment and processes. The fourth source of contamination (systematic and random) is being addressed using a larger set of blank results from multiple studies, in addition to the results from the field blanks collected from the CLUB study unit. The development of this approach and its methods are described by M.S. Fram, L.D. Olsen, and K. B elitz, U.S. Geological Survey, written commun. (2011) for V OCs and by OIsen and others (2010) for trace elements.

The first potential mode that was evaluated is the presence of impurities in the water used to collect the blank. Because the blanks were collected using blank water certified by the NWQL to contain less than the $L R L, M D L$, or MRL of the analytes investigated in the study, the blank water is rarely the source of constituents detected in blanks. However, blank water sometimes is used before the certification process has been completed; thus, the certificates of analysis always must be checked. Blank water used in the CLUB study unit was certified by the NWQL prior to field blank collection.

The second potential mode that was evaluated is contamination from identifiable, known sources present at a specific field site. Contamination from specific sources may produce distinctive patterns of detections in blanks and groundwater samples, particularly for the V OCs. Substances that may be encountered at the field site contain recognizable associations of V OC constituents. For example, cements used on polyvinyl chloride (PVC) piping are primarily composed of tetrahydrofuran with lesser amounts of acetone and methyl ethyl ketone (2-butanone). However, detection of these recognizable associations of V OC constituents in groundwater samples does not necessarily indicate contamination during sample collection because these V OC constituents also may occur together in groundwater.

If a recognizable association of $\mathrm{VOC}$ constituents was detected in a field blank or in a groundwater sample, the field notes and photographs from the site at which the field blank or groundwater sample was collected were examined for conditions that may have caused the field blank or the groundwater sample to be contaminated. If such conditions were present, the detections of VOC constituents in the field blank or groundwater sample were considered suspect.

The third potential mode of contamination that was evaluated was carry-over from the previous groundwater sample or blank collected with the same equipment. Carry-over between samples is rare because the procedures used to clean the equipment between samples have been developed and extensively tested to assure that carry-over is mitigated as much as possible. Potential carry-over was evaluated using time-series analysis to look for patterns suggestive of carry-over of constituents from a sample with high concentrations to the next groundwater sample or blank collected with the same equipment. If non-detections were reported in blanks or groundwater samples collected after the collection of groundwater samples containing high concentrations of the constituent, then carry-over as a mode of contamination was ruled out.

The fourth potential mode of contamination that was evaluated was random or systematic contamination from field or laboratory equipment or processes. All detections in blanks that could not be accounted for by impurities in the source-solution water, by specific known conditions at field sites, or by carry-over betw een samples were evaluated for random contamination. Random contamination in field and laboratory processes has an equal chance of affecting each groundwater sample; thus, strategies for flagging detections of constituents that are subject to random contamination in field and laboratory processes must be applied to all groundwater samples. Random or systematic contamination in field and laboratory processes generally is the most common of the four modes of contamination and is addressed by applying SRL $S$. 
The SRLs for some VOCs were defined on the basis of concentrations and detection frequencies in field blanks and source-solution blanks collected for the first 32 GAMA-PBP study units ( $M$ ay 2004 through September 2010) and in NW Q L instrument and preparation blanks analyzed during the same time period as the samples (M .S. Fram, L.D. Olsen, and K. Belitz, U.S. Geological Survey, written commun., 2011). SRLs were defined for five hydrocarbons (ethylbenzene, toluene, 1,2,4-trimethylbenzene, $\mathrm{m}$ - and $\mathrm{p}$-xylenes, and 0 -xylene), three solvents (acetone, 2-butanone, and tetrahydrofuran), and one VOC that occurs naturally and also is used in industrial processes (carbon disulfide).

For organic and special-interest constituents detected less frequently in blanks than in groundwater samples, the concentration corresponding to the $95^{\text {th }}$ percentile of the cumulative frequency distribution of the field blanks, source-solution blanks, or laboratory blanks, whichever was highest, was defined as the SRL. For most constituents, the $95^{\text {th }}$ percentiles of the cumulative frequency distributions were non-detections (values bel ow the RL); thus, no SRL s were required. Concentrations of those constituents reported by the laboratory that were less than the SRL are flagged with a less than or equal to $(\leq)$ symbol preceding the reported value. Organic and special-interest constituent results flagged with a $\leq$ symbol were not considered detections in the GAMAPBP study and were not included in the calculations of detection frequencies.

The SRL $s$ for all trace el ements except cobalt and molybdenum were determined by statistical assessment of results from the field blanks collected in the first 20 GA M A -PBP study units (M ay 2004 through J anuary 2008) (Olsen and others, 2010). The assessment used order statistics and binomial probabilities to construct an upper confidence limit (Hahn and Meeker, 1991) for the maximum concentration of constituents possibly introduced while groundwater samples were collected, handled, transported, and analyzed. The resulting SR L s for trace elements were set at concentrations representing a confidence limit of 90 percent for the $90^{\text {th }}$ percentile of the 86 field blanks used in the assessment. Concentrations of those constituents reported by the NWQL that were less than the SRL are flagged with a $\leq$ symbol preceding the reported value.

For all other inorganic constituents, the SRL for applying the $\leq$ symbol was determined from assessment of the field blanks collected in the CLUB study unit and was defined as equal to the highest concentration measured in the field blanks.

\section{Replicates}

Sequential replicate samples were collected to assess the precision of the water-quality data. Estimates of data precision are needed to assess whether differences between concentrations in samples are because of differences in groundwater quality or because of variability that may result from collecting, processing, and analyzing the samples.
Two methods for measuring variability were needed to adequately assess precision over the broad range of measured concentrations of most constituents. The variability between measured concentrations in the pairs of sequential replicate samples was represented by the standard deviation (SD) for low concentrations and by relative standard deviation (RSD) for high concentrations (A nderson, 1987; M ueller and Titus, 2005). The RSD is defined as the SD divided by the mean concentration for each replicate pair of samples expressed as a percentage. The boundary between concentrations for which variability is assessed with SD and concentrations for which variability is assessed with RSD was defined as five times the reporting level $(R L)$ for each constituent. The $R L$ may be an $L R L, S R L, M D L$, or $M R L$ for each constituent.

For this study, acceptable precision for replicate sample pairs is defined as follows.

- For concentrations less than five times the RL $(<5 \mathrm{RL})$, an $S D$ of $<1 / 2$ the $R L$ is acceptable.

- For concentrations greater than (or equal to) five times the RL ( $\geq 5 \mathrm{RL}$ ), an RSD of $<10$ percent is acceptable. For comparison, an RSD of 10 percent is equivalent to a relative percent difference (RPD) of 14 percent.

- For activities of radiochemical constituents (except carbon-14), replicate pairs with values that are statistically indistinguishable at a confidence level $(\alpha)$ of $\alpha=0.05$ are defined as acceptable.

If results from replicate sample pairs indicate that precision is unacceptable for a constituent and no specific reason can be identified, then this greater variability must be considered when interpreting the data. If measured concentrations are slightly greater than a water-quality benchmark, then actual concentrations could be slightly less than that benchmark. Similarly, if measured concentrations are slightly less than a water-quality benchmark, then actual concentrations could be slightly greater than a benchmark. A Iso, if a constituent has high variability in replicate sample pairs, then a larger difference between concentrations measured in two samples is required to conclude that the two samples have significantly different concentrations.

Replicate pairs of analyses of all constituents except for radiochemical constituents were evaluated as follows.

- If both values were reported as detections, the SD was calculated if the mean concentration was $<5 R L$ for the constituent, or the RSD was calculated if the mean concentration was $\geq 5 \mathrm{RL}$ for the constituent.

- If both values were reported as non-detections, the variability was set to zero by definition.

- If one value was reported as a non-detection, and the other value was reported as a detection less than the $R L$, then a value of zero was substituted for the non-detection, and the SD was calculated. Substituting zero for the non-detection yielded the maximum estimate of variability for the replicate pair. 
- If one value for a sample pair was reported as a non-detection and the other value was reported as a $\leq$-coded value (less than or equal to the SRL), or if both values were reported as $\leq$-coded values (less than or equal to the $S R L$ ), the SD was not calculated because the values may be analytically identical. The $\leq$-code indicates that the value is a maximum potential concentration and that concentration may be low enough to be reported as a non-detection.

- If one value was reported as a non-detection and the other value was reported as a detection greater than the $R L$, the variability for the pair was considered unacceptable.

Replicate pairs of analyses of radiochemical constituents were evaluated using the following equation ( $\mathrm{M} \mathrm{cC}$ urdy and others, 2008):

$$
z=\frac{\left|R_{1}-R_{2}\right|}{\sqrt{\left(\operatorname{CSU}_{1}^{2}+\operatorname{CSU}_{2}^{2}\right)}},
$$

where

$\mathrm{z}$ is the test statistic,

$R_{1}$ and $R_{2}$ are the results for the two samples in the replicate pair, and

$\mathrm{CSU}_{1}^{2}$ and $\mathrm{CSU}_{2}^{2}$ are the combined standard uncertainties associated with the results.

Values of $\mathrm{z}<1.65$ correspond to significant levels $(\mathrm{p})<\alpha=$ 0.05 , and thus indicate replicate pairs with acceptable precision.

\section{Matrix Spikes}

A ddition of a known concentration of a constituent (spike) to a replicate environmental sample enables the analyzing laboratory to determine the effect of the matrix, in this case groundwater, on the analytical technique used to measure the constituent. The known compounds added in matrix spikes are the same as those being analyzed in the method. This enables an analysis of matrix interferences on a compound-by-compound basis. For this study, matrix spikes were added by the laboratory performing the analysis. Low matrix-spike recovery may indicate that the compound might not be detected in some samples if it were present at very low concentrations. Low and high matrix-spike recoveries may be a potential concern if the concentration of a compound in a groundwater sample is close to the health-based benchmark; a low recovery could result in a fal sely measured concentration less than the health-based benchmark, whereas a high recovery could result in a falsely measured concentration greater than the health-based benchmark.
The GAMA-PBP defined the data-quality objective range for acceptable matrix-spike recoveries as 70 to 130 percent. Only constituents with median matrix-spike recoveries outside of this range were flagged as having unacceptable recoveries. For many constituents, an acceptable range of 70 to 130 percent for matrix-spike recovery was more restrictive than the acceptable control limits for laboratory-set spike recoveries. Laboratory-set spikes are aliquots of laboratory blank water to which the same spike solution used for the matrix spikes has been added. One set spike is analyzed with each set of samples. A cceptable control limits for set spikes are defined relative to the long-term variability in recovery. For example, for many NW QL schedules, acceptable set-spike recovery is within $\pm 3 \mathrm{~F}$-pseudosigma of the median recovery for at least 30 set spikes (Conner and others, 1998). The F-pseudosigma is calculated by dividing the fourth-spread (analogous to interquartile range) by 1.349; therefore, the smaller the F-pseudosigma, the more precise the determinations (H oaglin, 1983).

$M$ atrix spikes were performed for $\mathrm{V} O \mathrm{C} s$, pesticides and pesticide degradates, pharmaceutical compounds, perchlorate, and NDM A because the analytical methods for these constituents may be susceptible to matrix interferences.

\section{Surrogates}

Surrogate compounds are added to groundwater samples in the laboratory prior to analysis to evaluate the recovery of similar constituents. Surrogate compounds were added in the laboratory to all groundwater and QC samples that were analyzed by the NW QL for V OCs, pesticides, and pharmaceutical compounds. M ost of the surrogate compounds are deuterated analogs of compounds being analyzed. For example, the surrogate toluene-d8 that is used for the V OC analytical method has the same chemical structure as toluene, except that the eight hydrogen-1 atoms on the molecule have been replaced by deuterium (hydrogen-2). Toluene- $d 8$ and toluene behave very similarly in the analytical procedure, but the small mass difference between the two results in slightly different chromatographic retention times; thus, the use of a toluene-d8 surrogate does not interfere with the analysis of toluene (Grob, 1995). Only 0.015 percent of hydrogen atoms are deuterium (Firestone and others, 1996); thus, deuterated compounds such as toluene-d8 do not occur naturally and are not detected in groundwater samples. Surrogates are used to identify general problems that may arise during laboratory sample analysis that could affect the analysis results for all compounds in that sample. Potential problems include matrix interferences (such as high levels of DOC) that produce a positive bias or incomplete laboratory recovery (possibly because of improper maintenance and calibration of analytical equipment) that produces a negative bias. A 70 to 130 percent recovery of surrogates, in general, is considered acceptable; values outside this range indicate possible problems with the processing and analysis of samples (Connor and others, 1998; Sandstrom and others, 2001). 


\section{Quality-Control Results}

\section{Detections in Field Blanks and Application of SRLS}

Table A 3 presents a summary of detections in the field blanks and the SRLs applied for the CLUB study unit. Field blanks were collected at approximately 2 to 10 percent of the sites sampled in the CLUB study unit.

Of the five field blanks analyzed for VOCs, PCE was detected in one blank. The PCE detection was considered to be random contamination, likely from a field process, but the exact source could not be identified. This blank detection had an equal chance of affecting each groundwater sample. PCE was detected in the field blank at a concentration of E $0.02 \mu \mathrm{g} / \mathrm{L}$, creating an SRL of $0.02 \mu \mathrm{g} / \mathrm{L}$. PCE was detected at concentrations less than the SRL in two groundwater samples, and these concentrations were flagged with a $\leq$ symbol. These groundwater samples were reclassified as non-detections and were not included in the calculations of PCE detection frequencies (tables 5 and A 3).

GAM A SRLs from M.S. Fram, L.D. Olsen, and K. B elitz, U.S. Geological Survey, written commun. (2011) were used for nine V OCs. Of these V OCs with SRLs, three were detected in field blanks and (or) groundwater samples from the CLUB study unit. Toluene was detected in 1 of 5 field blanks at a concentration of E $0.02 \mu \mathrm{g} / \mathrm{L}$ (table A 3) and in two groundwater samples at concentrations of E $0.01 \mu \mathrm{g} / \mathrm{L}$ and $\mathrm{E} 0.02 \mu \mathrm{g} / \mathrm{L}$ (table 5). B oth detections were measured at concentrations less than the SRL of $0.69 \mu \mathrm{g} / \mathrm{L}$ and were reclassified as non-detections. The source of the toluene contamination is uncertain.

1,2,4-trimethyl benzene was detected in 12 of 52 groundwater samples at concentrations ranging from $\mathrm{E} 0.01 \mu \mathrm{g} / \mathrm{L}$ to $1.82 \mu \mathrm{g} / \mathrm{L}$ (median $0.21 \mu \mathrm{g} / \mathrm{L}$ ) (table 5 ). $\mathrm{N}$ ine of the detections were measured at concentrations less than the SRL of $0.56 \mu \mathrm{g} / \mathrm{L}$ and were reclassified as non-detections. The three remaining detections were considered to be representative of groundwater quality and are presented on table 5 . For the GA M A-PBP, detections of 1,2,4-trimethylbenzene in blanks and groundwater samples are correlated with the presence in field vehicles of equipment used for collecting radon samples (M .S. F ram, L.D. Olsen, and K. B elitz, U.S. G eological Survey, written commun., 2011). The vials used to collect radon samples contain a scintillation cocktail made of mineral oil and 1,2,4-trimethylbenzene. Radon samples were collected at 22 wells in the CLUB study unit; therefore, there was a potential for the contamination of groundwater samples.

A cetone was detected in one groundwater sample at a concentration of $7 \mu \mathrm{g} / \mathrm{L}$ (table 5). Contamination of groundwater samples and field blanks by acetone, tetrahydrofuran, and (or) 2-butanone is associated with presence of PV C-cement at sample collection sites (some wells are plumbed with PV C piping) and with contamination of sample collection equipment by the methanol used for cleaning equipment (M.S. Fram, L.D. Olsen, and K. B elitz, U.S. Geological Survey, written commun., 2011). Field blanks with contamination from either of these two sources were not considered representative; therefore, no QC assessment could be made for these three solvents, and no concentration threshold could be established for the SRL. The SRL consists of reclassifying these three solvents as "not analyzed" and detections in groundwater samples as non-detections.

Five field blanks were collected for analysis of trace elements. Five trace elements were detected in at least one field blank-cobalt, copper, iron, lead, and molybdenum (table A 3). The detections of copper, iron, and lead were measured at concentrations less than the SRL assigned by OIsen and others (2010). SRL $s$ for cobalt $(0.18 \mu \mathrm{g} / \mathrm{L})$ and molybdenum $(0.32 \mu \mathrm{g} / \mathrm{L})$ were established on the basis of the highest detected concentration in the two field blanks. $M$ easured concentrations that were less than the $S R L$ were flagged with a symbol (table 8). There were no other trace elements detected in any of the field blanks in the CLUB study unit.

GA M A SRL s from Olsen and others (2010) were used for aluminum, barium, chromium, copper, iron, lead, manganese, nickel, tungsten, vanadium, and zinc. M easured concentrations that were less than the SRL were flagged with a $\leq$ symbol in table 8 .

Two field blanks were collected for analysis of radioactive constituents. Results from field blanks were not used to define SRLs for radiochemical constituents because the low activities of these constituents occasionally reported in GA M A -PBP blanks are thought to be an artifact of the al gorithms used to convert instrument response to activities for blank samples, rather than to reflect presence of these constituents in blank samples (Sylvia Stork, U.S. Geological Survey, written commun., 2010). A ctivities of radiochemical constituents reported in field blanks were lower than most of the activities reported in the CLUB study-unit groundwater samples, indicating that groundwater samples likely were not significantly contaminated by these constituents during collection, handling, or analysis (tables 14 and $\underline{A}$ ).

Constituents were not detected in the field blanks for the following analyte groups: pesticides and pesticide degradates (five field blanks); perchlorate (three field blanks); NDMA (two field blanks); nutrients (five field blanks); major and minor ions, silica, and TDS (five field blanks); species of inorganic chromium (one field blank); Cr-VI from TALIR (one field blank); radium-228 (two field blanks); gross alpha radioactivity (30-day count, two field blanks); and gross beta radioactivity (72-hour and 30-day counts, two field blanks).

\section{Variability in Replicate Samples}

Table A 4A-C summarizes the results of replicate analyses for constituents detected in groundwater samples collected in the CLUB study unit. Replicate analyses were made on approximately 4 to 10 percent of the samples collected. 
Of the 944 replicate pairs of constituents analyzed, 269 were for constituents detected in at least one groundwater sample. Of these 269 pairs, 2 pairs (tritium) were outside the limits for acceptable precision. Results for replicate analyses for constituents that were not detected in groundwater samples are not reported in table A $4 \mathrm{~A}-\mathrm{C}$.

Five replicate pairs of samples were analyzed for the $85 \mathrm{VOCs}$, and all pairs were composed of two values reported as non-detections or two values $\leq$-coded with the exception of two replicate pairs of chloroform and PCE and one replicate pair of diisopropyl ether (DIPE), benzene, and trichloroethene (TCE) (table A 4A). These replicate pairs either yielded two values reported as detections or one value reported as a detection and one reported as a non-detection. All replicate pair analyses resulted in SDs and RSDs within acceptable precision.

Five replicate pairs of samples were analyzed for the 63 pesticide and pesticide degradate compounds and all pairs were composed of two values reported as non-detections with the exception of one replicate pair of atrazine, deethylatrazine, 3,4-dichloroaniline, and dieldrin (table A 4A). The replicate pairs all yielded two values reported as detections, and all replicate pair analyses resulted in SDs within acceptable precision.

Five replicate pairs for perchlorate and two replicate pairs for NDM A were analyzed at Weck L aboratories, Inc., for variability (table A 4A). One of the replicate pairs for perchlorate and both replicate pairs for NDM A were composed of two values reported as non-detections. The other four replicate pairs for perchlorate yiel ded two values reported as detections, and all replicate pair analyses resulted in SDs or RSD s within acceptable precision.

Replicate pairs of samples were analyzed for the 24 trace elements (four pairs); 5 nutrients (four pairs); 9 major and minor ions, silica, and TDS (four pairs); Cr-V I from TALIR (two pairs); and 4 isotope tracers (four pairs). The SD or RSD values for all pairs were within acceptable precision (table A 4B).

Five replicate pairs for tritium were analyzed for variability (table A 4C). Two of these replicate pairs resulted in values of $p>0.05$, which indicates that these replicate pairs do not have acceptable precision. However, these samples were reported as non-detections and (or) concentrations more than four orders of magnitude less than the corresponding M CL-CA (tables 3 J and 13). For tritium concentrations less than health-based benchmarks, precision that is less than acceptable will not affect the assessments of groundwater quality being made by the GAMA-PB P.

Two replicate pairs for radon-222, radium isotopes, and gross al pha and gross beta radioactivity were analyzed for variability (table A 4C). A II replicate pairs for these radioactive constituents yielded statistically similar results $(\mathrm{p} \leq 0.05)$ and were, therefore, considered acceptable.

Environmental detections were not modified on the basis of the replicate analysis.

\section{Matrix-Spike Recoveries}

Table A $5 A-C$ presents a summary of matrix-spike recoveries for the CLUB study unit. Replicate samples for spike additions were collected at approximately 2 to 10 percent of the wells sampled.

Five groundwater samples were spiked with $\mathrm{V} O \mathrm{CS}$ to cal culate matrix-spike recoveries (table A 5A). M edian matrix-spike recoveries for all $85 \mathrm{~V} \mathrm{OC}$ spike compounds were between 70 and 130 percent. Eight V OC spike compounds had one matrix-spike recovery greater than 130 percent. of these V OC spike compounds, one constituent, chloroform, also was detected in groundwater samples (tables $3 \mathrm{~A}$ and $\underline{5}$ ). Three V OC spike compounds had one matrix-spike recovery less than 70 percent, and none of these $\mathrm{VOC}$ spike compounds were detected in groundwater samples (tables $3 A$ and A $5 A$ ).

Five groundwater samples were spiked with pesticide and pesticide degradate compounds to calculate matrix-spike recoveries (table A 5B). M edian matrix-spike recoveries for 40 of the 63 spike compounds were between 70 and 130 percent. Twenty-four of the compounds had median matrix-spike recoveries less than 70 percent. One compound (tebuthiuron) had a median matrix-spike recovery greater than 130 percent.

Two of the three compounds detected in groundwater samples (3,4-dichloroaniline and atrazine) had median matrix-spike recoveries within the acceptable range (tables 3B and $\underline{6}$ ).

The median matrix-spike recovery for the third compound detected in groundwater samples, deethylatrazine, had a median matrix-spike recovery less than the acceptable range (63 percent). D eethylatrazine was detected at concentrations $(E 0.009 \mu \mathrm{g}$ and $E 0.007 \mu \mathrm{g})$ less than the $L R L$ of $0.014 \mu \mathrm{g}$ in two grid wells in the LUB study area (table 6). B ecause deethylatrazine was detected at concentrations much lower than the $L R L$, it was determined that the less than acceptable median matrix-spike recovery did not affect the analysis and results from the NW Q L. Tebuthiuron had a median matrix-spike recovery of 149 percent, but this compound was not detected in groundwater samples.

A t least one matrix-spike recovery for six pesticide and pesticide degradate spike compounds was greater than 130 percent (table A 5B). Of these six, four pesticide and pesticide degradate spike compounds had at least one matrix-spike recovery greater than 130 percent and one matrix-spike recovery less than 70 percent. A t least one matrix-spike recovery for 48 pesticide and pesticide degradate spike compounds was less than 70 percent. Of these pesticide and pesticide degradate spike compounds, 3,4-dichloroaniline and deethylatrazine were detected in groundwater samples (tables $3 B, \underline{6}$, and $\underline{A} 5 B$ ). A similar pattern of unusually low matrix-spike recoveries that started in $M$ arch 2008 was noted in an assessment of method performance by the Organic B lind Sample Program (OBSP) of the BQS (http://bqs.usgs. gov/OBSP/). 
One groundwater sample was spiked with perchlorate, and two groundwater samples were spiked with NDM A to calculate matrix-spike recoveries at Weck $L$ aboratories, Inc. (table A 5C). A II median matrix-spike recoveries were between 70 and 130 percent.

Environmental detections were not modified on the basis of the matrix-spike recovery analysis.

\section{Surrogate Compound Recoveries}

Table $A 6$ presents a summary of the surrogate recoveries for the CLUB study unit. The table lists the surrogate, the analytical schedule on which it was applied, the number of analyses for blank and environmental samples, the number of surrogate recoveries less than 70 percent, and the number of surrogate recoveries greater than 130 percent for the blank and environmental samples. B lank and environmental samples were considered separately to assess whether or not the matrixes present in environmental samples affect surrogate recoveries.

M ost surrogate recoveries for the blank and environmental samples were within the acceptable range of 70 to 130 percent. In total, 93 percent of the blank and 83 percent of the environmental sample surrogate recoveries for $\mathrm{VOC}$ analyses were within the acceptable range (table A 6). In addition, 100 percent of the blank and 90 percent of the environmental sample surrogate recoveries for pesticide and pesticide degradate analyses were within the acceptable range (table $A 6$ ). There were no significant differences between $\mathrm{VOC}$ and pesticide and pesticide degradate surrogate recoveries in blank and environmental samples (Wilcoxon rank sum test, $p<0.05$ ).

Environmental detections were not modified on the basis of the surrogate recovery analysis.

\section{Other Quality-Control Results}

Two other laboratory QC matters arose during the analysis of samples collected for CLUB study unit: the effect of holding time violations on the results of radioactive constituent data and the effect of internal laboratory QC tests indicating bias on the results of trace element data.

$\mathrm{Hol}$ ding time refers to the time in cal endar days from sample collection to the analysis of the sample. A holding time violation is when a sample is analyzed past the given holding time for a particular analysis. The remote sampling areas within the CLUB study unit did not allow for immediate shipment of a few radioactive samples for the analysis of gross alpha and beta radioactivity. This resulted in the later arrival times at the laboratory; thus, the analysis was completed after the holding time. This may be important because a delay in the analysis at the laboratory may result in lower measured activities than what may have been present in the groundwater.
The gross alpha and beta radioactivity reported result is the amount measured in the sample. Radioactive decay occurs betw een the time of sample collection and measurement; therefore, gross al pha and gross beta change with time. Generally, gross alpha decreases during the first 10 days due to decay of unsupported members of the thorium-232 decay series (in particular, Ra-224 and its progeny). A t least one result from the analysis of gross alpha and beta radioactivity (72-hour count) was analyzed past the holding time for three groundwater samples. The results for these three samples are footnoted in table 14C. Gross al pha and beta radioactivity (72-hour count) will be lower in samples analyzed late. If there were samples with a gross al pha or beta radioactivity count just over the benchmark (or just over $1 / 2$ benchmark) that were present in the groundwater, then late analysis could result in the reported activities for these samples being below the benchmark. One of the late samples in the CLUB study unit may be in this category: gross alpha radioactivity (72-hour count) in LUB - 07 was measured at $10.5 \pm 2.1 \mathrm{pCi} / \mathrm{L}$. This sample was analyzed 4 days past the holding time.

L aboratory bias as indicated from internal laboratory QC tests is another issue that must be investigated to determine whether or not the data are affected. The B QS operates an independent, external QA project called the Inorganic B lind Sample Project (IBSP) to monitor and evaluate the quality of results for analyses of trace elements, nutrients, major and minor ions, silica, and TDS by the NW QL. The IBSP submits standard reference samples consisting of natural matrix water samples spiked with reagent chemicals that contain known concentrations of the inorganic constituents (Farrar and L ong, 1997). The IBSP samples are disguised as regular groundwater samples for submission to the NWQL. The BQS uses results from the IBSP samples to evaluate potential bias, positive or negative, in the results reported by the NW QL on a continuous basis. The BQS IBSP data are readily available on the BQS website, and the BQS issues monthly summaries of the results, reporting the amount of bias (if any) observed in the results (http://bqs.usgs.gov/ibsp/).

The BQS monthly summaries were examined for the period of time during which samples were analyzed for the CLUB study unit. In summary, the BQS reported that four inorganic constituents showed evidence of bias: a positive bias for cadmium, sulfate, and zinc and a negative bias for magnesium. Examination of the results for the IB SP samples for these four constituents indicated that the analytical biases reported by the BQS were not significant for the data collected for the CLUB study unit.

The IBSP samples for cadmium had concentrations ranging from $0.18 \mu \mathrm{g} / \mathrm{L}$ to $1.8 \mu \mathrm{g} / \mathrm{L}$. The average difference between the measured and expected concentrations was $0.14 \mu \mathrm{g} / \mathrm{L}$ (standard deviation $=0.08 \mu \mathrm{g} / \mathrm{L}$ ), and the average relative percent difference between the measured and expected concentrations was 16 percent (standard deviation = 22 percent). The M CL-US for cadmium is $5 \mu \mathrm{g} / \mathrm{L}$, thus the 
estimate of bias from the ISBP samples would be relevant for assessment of whether groundwater samples have cadmium concentrations greater than or less than the M CL -US concentration or greater than or less than $1 / 2$ of the M CL -US concentration. However, the maximum concentration of cadmium in samples from the CLUB study unit was $0.45 \mu \mathrm{g} / \mathrm{L}$ (table 8); thus, a potential positive bias of $0.14 \mu \mathrm{g} / \mathrm{L}$ or 16 percent would not result in a measured concentration above either threshold when the true concentration would have been below the threshold.

The IBSP samples for sulfate had concentrations ranging from $14.9 \mathrm{mg} / \mathrm{L}$ to $31.3 \mathrm{mg} / \mathrm{L}$. The average difference betw een the measured and expected concentrations was $0.7 \mathrm{mg} / \mathrm{L}$ (standard deviation $=1.1 \mathrm{mg} / \mathrm{L}$ ), and the average relative percent difference between the measured and expected concentrations was 4 percent (standard deviation = 6 percent). The upper SM CL-CA for sulfate is $500 \mathrm{mg} / \mathrm{L}$, a concentration much higher than the maximum concentration in the IB SP samples. A positive bias of 4 percent or $0.7 \mathrm{mg} / \mathrm{L}$ for groundwater samples with measured concentrations of less than $31.3 \mathrm{mg} / \mathrm{L}$ (table 10) does not affect assessment of whether groundwater samples in the CLUB study unit have sulfate concentrations greater than or less than the upper SM CL -CA concentration or greater than or less than $1 / 2$ of the upper SM CL-CA concentration. M oreover, a determination of bias at low concentrations does not imply that there is equivalent bias at higher concentrations.
The IBSP samples for zinc had concentrations ranging from $5.9 \mu \mathrm{g} / \mathrm{L}$ to $36.4 \mu \mathrm{g} / \mathrm{L}$. The average difference between the measured and expected concentrations was $1.6 \mu \mathrm{g} / \mathrm{L}$ (standard deviation $=1.9 \mu \mathrm{g} / \mathrm{L}$ ), and the average relative percent difference between the measured and expected concentrations was 8 percent (standard deviation = 15 percent). The SM CL-CA for zinc is 5,000 $\mu \mathrm{g} / \mathrm{L}$, a concentration much higher than the maximum concentration in the IBSP samples. A positive bias of 8 percent or $1.6 \mu \mathrm{g} / \mathrm{L}$ for groundwater samples with measured concentrations of less than $36.4 \mu \mathrm{g} / \mathrm{L}$ (table 8) does not affect assessment of whether groundwater samples in the CLUB study unit have sulfate concentrations greater than or less than the SM CL-CA concentration or greater than or less than $1 / 2$ of the SM CL-CA concentration.

The IB SP samples for magnesium had concentrations ranging from $0.05 \mathrm{mg} / \mathrm{L}$ to $7.3 \mathrm{mg} / \mathrm{L}$. The average difference between the measured and expected concentrations was $-0.19 \mathrm{mg} / \mathrm{L}$ (standard deviation $=0.2 \mathrm{mg} / \mathrm{L}$ ), and the average relative percent difference betw een the measured and expected concentrations was -6 percent (standard deviation $=$ 3 percent). A negative bias of 6 percent or $0.2 \mathrm{mg} / \mathrm{L}$ can only potentially affect measured concentrations of less than $7.3 \mathrm{mg} / \mathrm{L}$ in CLUB study unit groundwater samples (table 10). $M$ agnesium does not currently have an established regulatory or non-regulatory health-based benchmark or a non-regulatory benchmark established for aesthetic concerns; therefore, this negative bias will not affect the assessments of groundwater quality being made by the GAMA-PBP. 


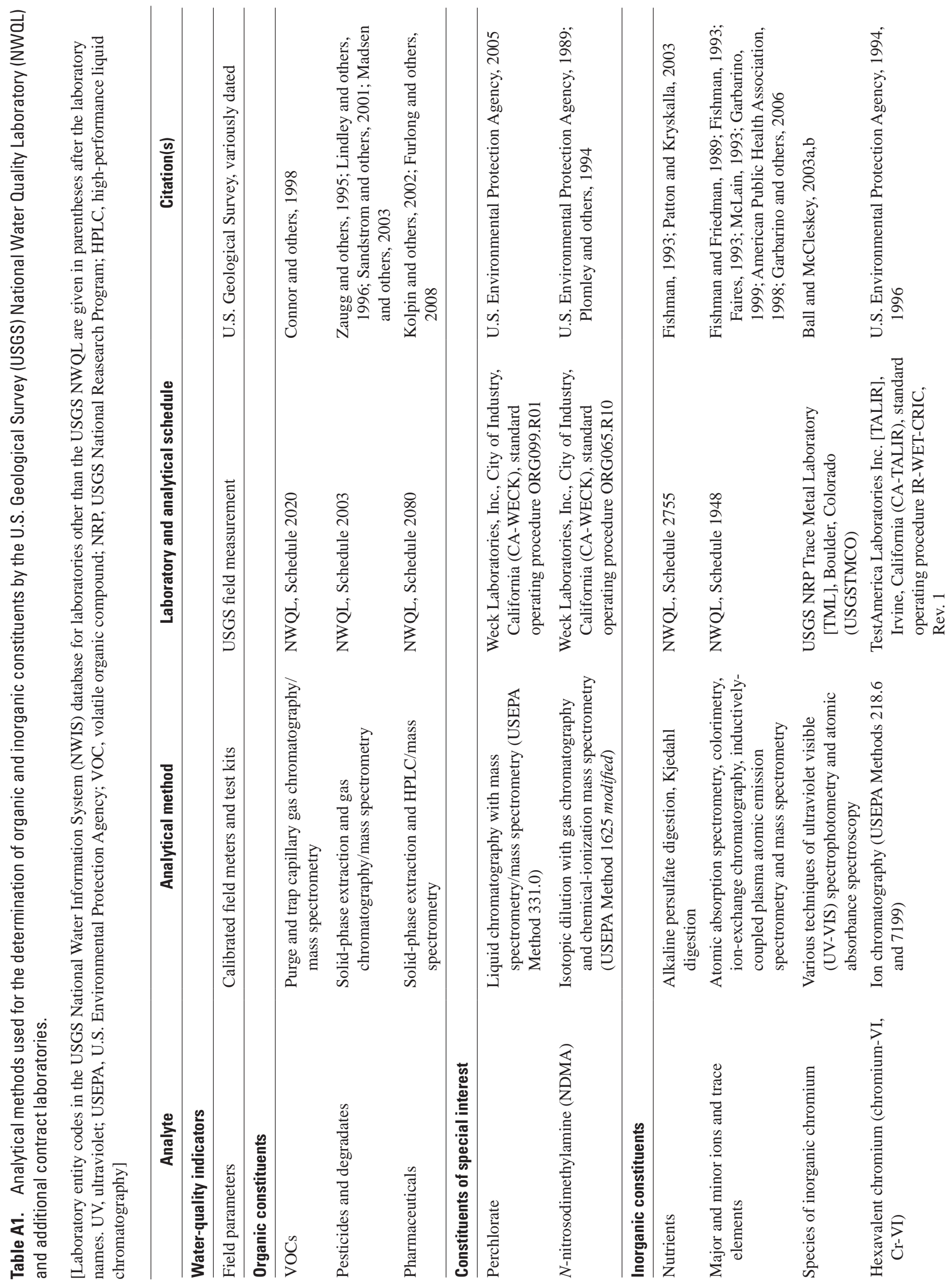




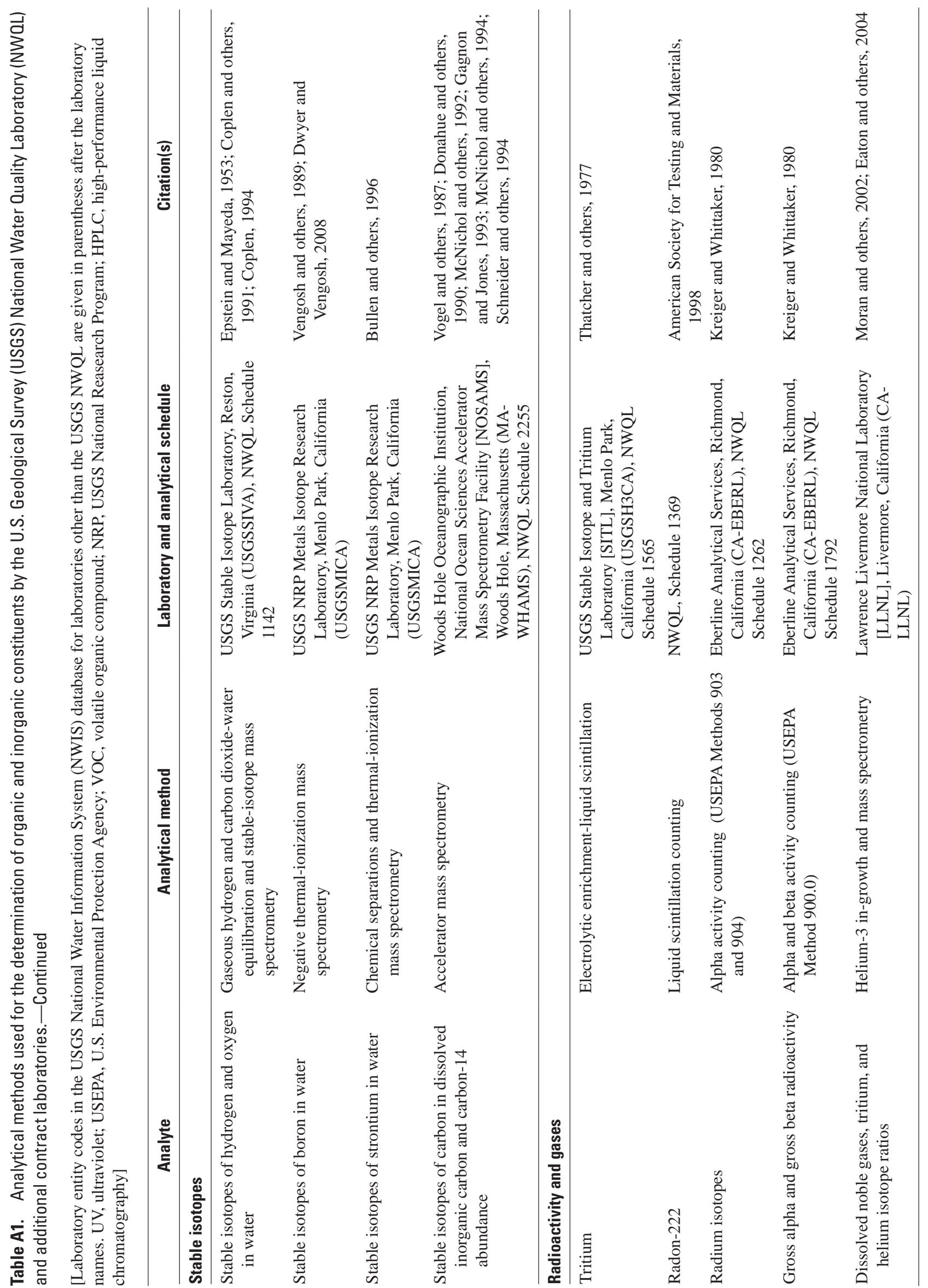


Table A2. Preferred analytical schedules for selected constituents collected for the Borrego Valley, Central Desert, and Low-Use Basins of the Mojave and Sonoran Deserts (CLUB) Groundwater Ambient Monitoring and Assessment (GAMA) study, California, December 2008 to March 2010.

[Preferred analytical schedules/methods are selected on the basis of the procedure recommended by the USGS National Water Quality Laboratory (NW QL) (http://wwwnwql.cr.usgs.gov/dyn.shtml?Preferred method selection_procedure). Abbreviations: TML, USGS Trace M etal Laboratory, B oulder, Colorado; TA LIR, TestA merica, Inc., Irvine, California; np, no preference; SITL, USGS Stable Isotope L aboratory, Reston, Virginia; LL NL, Lawrence Livermore National Laboratory, Livermore, California; USGS, U.S. Geological Survey]

\begin{tabular}{lllc}
\hline \multicolumn{1}{c}{ Constituent } & \multicolumn{1}{c}{$\begin{array}{c}\text { Primary constituent } \\
\text { classification }\end{array}$} & $\begin{array}{c}\text { Analytical } \\
\text { schedules }\end{array}$ & $\begin{array}{c}\text { Preferred analytical } \\
\text { schedule }\end{array}$ \\
\hline Results from both methods reported & & & \\
\hline Alkalinity & Water-quality indicator & Field, 1948 & Field \\
pH & Water-quality indicator & Field, 1948 & Field \\
Specific conductance & Water-quality indicator & Field, 1948 & Field \\
Chromium, total & Trace element & $1948, T M L$ & 1948 \\
Hexavalent chromium (chromium-VI, Cr-VI) & Trace element species & TML, TALIR & $\mathrm{np}$ \\
Tritium & Inorganic tracer & SITL, LLNL & $\mathrm{np}$ \\
\hline
\end{tabular}


Table A3 91

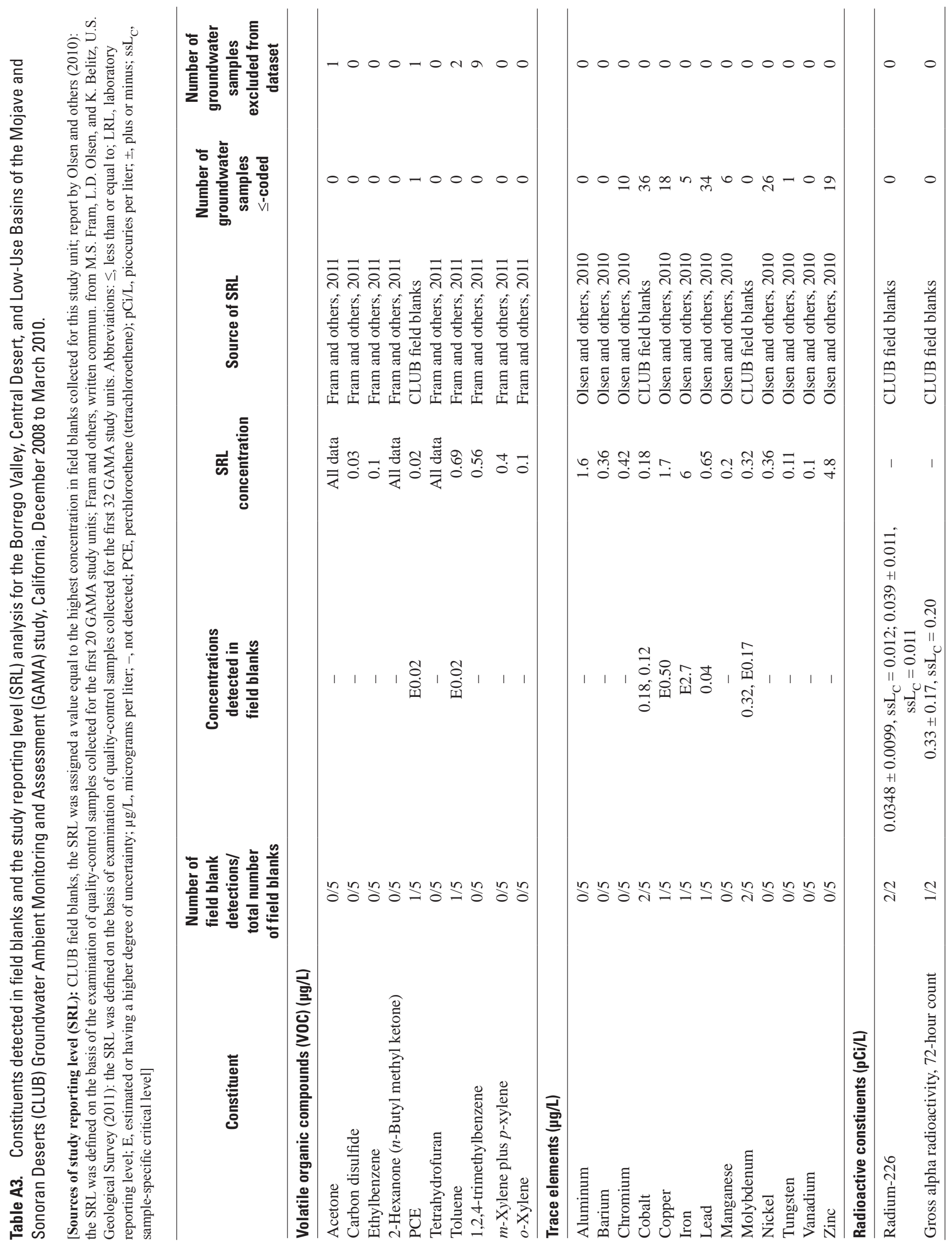




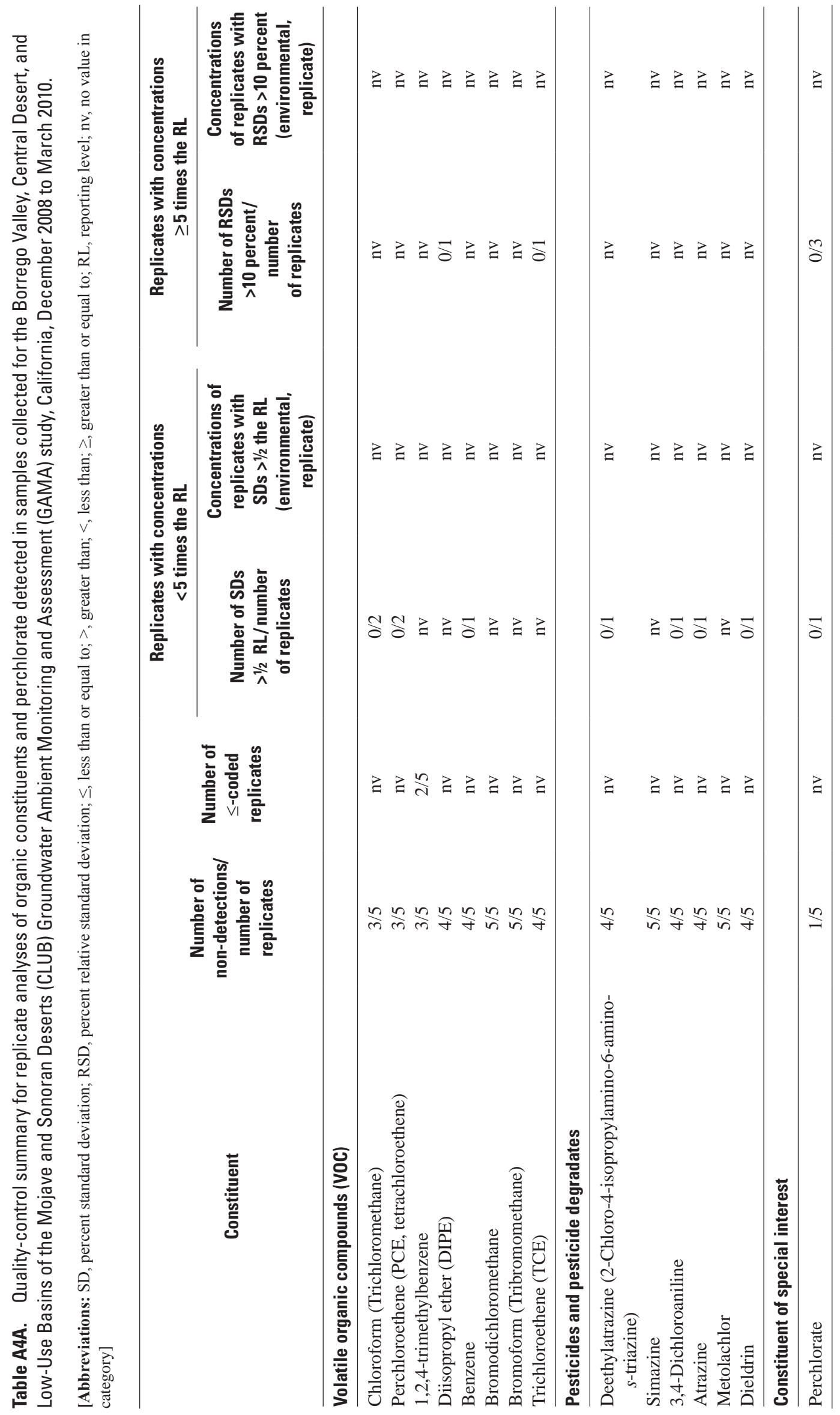


Table A4B. Quality-control summary for replicate analyses of inorganic constituents and isotope tracers detected in samples collected for the Borrego Valley, Central Desert, and Low-Use Basins of the Mojave and Sonoran Deserts (CLUB) Groundwater Ambient Monitoring and Assessment (GAMA) study, California, December 2008 to March 2010.

[Abbreviations: SD, percent standard deviation; RSD, percent relative standard deviation; >, greater than; $<$, less than; $\geq$, greater than or equal to; RL, reporting level; $\mu \mathrm{g} / \mathrm{L}$, micrograms per liter; $\mathrm{Cr}$-VI, hexavalent chromium (chromium-VI); TA LIR, TestA merica L aboratories, Inc., Irvine, California; SiO ${ }_{2}$, silicon dioxide; $\mathrm{H}$, hydrogen; $\mathrm{O}$, oxygen; $\mathrm{C}$, carbon; $\leq$, less than or equal to; $\mathrm{nv}$, no value in category]

\begin{tabular}{|c|c|c|c|c|c|}
\hline \multirow[b]{2}{*}{ Constituent } & \multirow{2}{*}{$\begin{array}{l}\text { Number of } \\
\text { non-detections } \\
\text { or } \leq- \text {-coded } \\
\text { replicates/ } \\
\text { number of } \\
\text { replicates }\end{array}$} & \multicolumn{2}{|c|}{$\begin{array}{l}\text { Replicates with concentrations } \\
\qquad 5 \text { times the } \mathrm{RL}\end{array}$} & \multicolumn{2}{|c|}{$\begin{array}{l}\text { Replicates with concentrations } \\
\qquad 5 \text { times the } R L\end{array}$} \\
\hline & & $\begin{array}{l}\text { Number of } \\
\text { SDs }>1 / 2 \text { the } \\
\text { RL/number } \\
\text { of replicates }\end{array}$ & $\begin{array}{l}\text { Concentrations } \\
\text { of replicates with } \\
\text { SDs }>1 / 2 \text { the } R L \\
\text { (environmental, } \\
\text { replicate) }\end{array}$ & $\begin{array}{l}\text { Number of RSDs } \\
>10 \text { percent } / \text { number } \\
\text { of replicates }\end{array}$ & $\begin{array}{l}\text { Concentrations } \\
\text { of replicates with } \\
\text { RSDs }>10 \text { percent } \\
\text { (environmental, } \\
\text { replicate) }\end{array}$ \\
\hline Aluminum & $3 / 4$ & $0 / 1$ & nv & nv & nv \\
\hline A ntimony & $2 / 4$ & $0 / 2$ & nv & nv & nv \\
\hline A rsenic & $0 / 4$ & nv & nv & $0 / 4$ & nv \\
\hline Barium & $0 / 4$ & nv & nv & $0 / 4$ & nv \\
\hline B eryllium & $3 / 4$ & $0 / 1$ & nv & nv & nv \\
\hline Cobalt & $0 / 4$ & $0 / 3$ & nv & $0 / 1$ & nv \\
\hline Copper & $3 / 4$ & $0 / 1$ & nv & nv & nv \\
\hline Iron & $3 / 4$ & $0 / 1$ & nv & nv & $\mathrm{nv}$ \\
\hline Lead & $4 / 4$ & $\mathrm{nv}$ & nv & nv & $\mathrm{nv}$ \\
\hline Lithium & $0 / 4$ & nv & nv & $0 / 4$ & nv \\
\hline M anganese & $1 / 4$ & $0 / 2$ & nv & $0 / 1$ & nv \\
\hline M olybdenum & $0 / 4$ & nv & nv & $0 / 4$ & nv \\
\hline Nickel & $0 / 4$ & $0 / 3$ & nv & $0 / 1$ & nv \\
\hline Selenium & $0 / 4$ & nv & nv & $0 / 4$ & nv \\
\hline Silver & $3 / 4$ & $0 / 1$ & nv & nv & nv \\
\hline Strontium & $0 / 4$ & $\mathrm{nv}$ & nv & $0 / 4$ & nv \\
\hline N itrate plus nitrite (as nitrogen) & $0 / 4$ & nv & nv & $0 / 4$ & nv \\
\hline N itrite (as nitrogen) & $3 / 4$ & nv & nv & $0 / 1$ & nv \\
\hline $\begin{array}{l}\text { Total nitrogen (ammonia + nitrite + } \\
\text { nitrate + organic nitrogen) }\end{array}$ & $0 / 4$ & $0 / 1$ & nv & $0 / 3$ & nv \\
\hline $\begin{array}{l}\text { Phosphate, orthophosphate (as } \\
\text { phosphorus) }\end{array}$ & $0 / 4$ & $0 / 4$ & nv & nv & nv \\
\hline
\end{tabular}


Table A4B. Quality-control summary for replicate analyses of inorganic constituents and isotope tracers detected in samples collected for the Borrego Valley, Central Desert, and Low-Use Basins of the Mojave and Sonoran Deserts (CLUB) Groundwater Ambient Monitoring and Assessment (GAMA) study, California, December 2008 to March 2010. - Continued

[Abbreviations: SD, percent standard deviation; RSD, percent relative standard deviation in percent; >, greater than; <, less than; $\geq$, greater than or equal to; $\mathrm{RL}$, reporting level; $\mu \mathrm{g} / \mathrm{L}$, micrograms per liter; $\mathrm{Cr}$-VI, hexaval ent chromium (chromium-VI); TA LIR, TestA merica L aboratories, Inc., Irvine, California; SiO ${ }_{2}$ silicon dioxide; $\mathrm{H}$, hydrogen; $\mathrm{O}$, oxygen; $\mathrm{C}$, carbon; $\leq$, less than or equal to; nv, no value in category]

\begin{tabular}{|c|c|c|c|c|c|}
\hline \multirow[b]{2}{*}{ Constituent } & \multirow{2}{*}{$\begin{array}{l}\text { Number of } \\
\text { non-detections } \\
\text { or } \leq- \text {-coded } \\
\text { replicates/ } \\
\text { number of } \\
\text { replicates }\end{array}$} & \multicolumn{2}{|c|}{$\begin{array}{l}\text { Replicates with concentrations } \\
\quad<5 \text { times the } R L\end{array}$} & \multicolumn{2}{|c|}{$\begin{array}{l}\text { Replicates with concentrations } \\
\quad \geq 5 \text { times the } R L\end{array}$} \\
\hline & & $\begin{array}{l}\text { Number of } \\
\text { SDs }>1 / 2 \text { the } \\
\text { RL/number } \\
\text { of replicates }\end{array}$ & $\begin{array}{l}\text { Concentrations } \\
\text { of replicates with } \\
\text { SDs }>1 / 2 \text { the } R L \\
\text { (environmental, } \\
\text { replicate) }\end{array}$ & $\begin{array}{l}\text { Number of RSDs } \\
>10 \text { percent / number } \\
\text { of replicates }\end{array}$ & $\begin{array}{c}\text { Concentrations } \\
\text { of replicates with } \\
\text { RSDs }>10 \text { percent } \\
\text { (environmental, } \\
\text { replicate) }\end{array}$ \\
\hline Bromide & $0 / 4$ & $0 / 4$ & nv & nv & nv \\
\hline Calcium & $0 / 4$ & nv & nv & $0 / 4$ & nv \\
\hline Chloride & $0 / 4$ & nv & nv & $0 / 4$ & nv \\
\hline Fluoride & $0 / 4$ & $0 / 3$ & nv & $0 / 1$ & nv \\
\hline Iodide & $0 / 4$ & $0 / 2$ & nv & $0 / 2$ & nv \\
\hline M agnesium & $0 / 4$ & nv & nv & $0 / 4$ & nv \\
\hline Silica (as $\mathrm{SiO}_{2}$ ) & $0 / 4$ & nv & nv & $0 / 4$ & nv \\
\hline TDS & $0 / 4$ & nv & nv & $0 / 4$ & nv \\
\hline \multicolumn{6}{|l|}{ Isotope tracers and radioactivity } \\
\hline$\delta^{2} \mathrm{H}$ in water & $0 / 4$ & nv & nv & $0 / 4$ & nv \\
\hline$\delta^{18} \mathrm{O}$ in water & $0 / 4$ & nv & nv & $0 / 4$ & nv \\
\hline$\delta^{13} \mathrm{C}$ in dissolved inorganic carbon & $0 / 4$ & nv & nv & $0 / 4$ & nv \\
\hline Carbon-14 & $0 / 4$ & nv & nv & $0 / 4$ & nv \\
\hline
\end{tabular}


Table A4C. Quality-control summary for replicate analyses of radioactive constiuents detected in samples collected for the Borrego Valley, Central Desert, and Low-Use Basins of the Mojave and Sonoran Deserts (CLUB) Groundwater Ambient Monitoring and Assessment (GAMA) study, California, December 2008 to March 2010.

[For activities of radiochemical constituents, a replicate pair of analyses is defined as acceptable if the p-value for the normalized absolute difference is less than the significance level, $\alpha=0.05$. Abbreviations: $>$, greater than; $\mathrm{pCi} / \mathrm{L}$, picocuries per liter; \pm , plus or minus; nv, no value in category; -, not detected]

\begin{tabular}{lcc}
\hline \multicolumn{1}{c}{ Constituent } & $\begin{array}{c}\text { Number of pairs } \\
\text { with } \mathbf{p}>\mathbf{0 . 0 5 / \text { total }} \\
\text { number of replicates }\end{array}$ & $\begin{array}{c}\text { Activites for replicate } \\
\text { pairs with } \mathbf{p}>\mathbf{0 . 0 5} \\
\text { (environmental, replicate) } \\
\text { (pCi/L) }\end{array}$ \\
\hline Tritium & $2 / 5$ & nv \\
Radon-222 & $0 / 2$ & $\mathrm{nv}$ \\
Radium-226 & $0 / 2$ & $\mathrm{nv}$ \\
Radium-228 & $0 / 2$ & $\mathrm{nv}$ \\
Gross al pha radioactivity, 72-hour count & $0 / 2$ & $\mathrm{nv}$ \\
Gross alpha radioactivity, 30-day count & $0 / 2$ & $\mathrm{nv}$ \\
Gross beta radioactivity, 72-hour count & $0 / 2$ & $\mathrm{nv}$ \\
Gross beta radioactivity, 30-day count & $0 / 2$ & $0.7 \pm 0.32)$ \\
\hline
\end{tabular}


Table A5A. Quality-control summary for matrix-spike recoveries of volatile organic compounds (VOC) in samples collected for the Borrego Valley, Central Desert, and Low-Use Basins of the Mojave and Sonoran Deserts (CLUB) Groundwater Ambient Monitoring and Assessment (GAMA) study, California, December 2008 to March 2010.

[A cceptable recovery range is between 70 and 130 percent]

\begin{tabular}{|c|c|c|c|c|}
\hline Constituent & $\begin{array}{l}\text { Number of } \\
\text { spike } \\
\text { samples }\end{array}$ & $\begin{array}{l}\text { Minimum } \\
\text { recovery } \\
\text { (percent) }\end{array}$ & $\begin{array}{c}\text { Maximum } \\
\text { recovery } \\
\text { (percent) }\end{array}$ & $\begin{array}{l}\text { Median } \\
\text { recovery } \\
\text { (percent) }\end{array}$ \\
\hline A cetone & 5 & 106 & 138 & 122 \\
\hline Acrylonitrile & 5 & 98 & 124 & 107 \\
\hline tert-A myl methyl ether (TA M E) & 5 & 89 & 115 & 104 \\
\hline B enzene ${ }^{1}$ & 5 & 91 & 109 & 105 \\
\hline Bromobenzene & 5 & 94 & 109 & 101 \\
\hline B romochloromethane & 5 & 106 & 129 & 116 \\
\hline B romodichloromethane ${ }^{1}$ & 5 & 89 & 111 & 108 \\
\hline B romoform (Tribromomethane) ${ }^{1}$ & 5 & 96 & 117 & 102 \\
\hline B romomethane (M ethyl bromide) & 5 & 100 & 147 & 127 \\
\hline n-Butylbenzene & 5 & 75 & 102 & 82 \\
\hline sec-Butylbenzene & 5 & 79 & 100 & 93 \\
\hline tert-Butylbenzene & 5 & 93 & 107 & 99 \\
\hline Carbon disulfide & 5 & 68 & 97 & 73 \\
\hline Carbon tetrachloride (Tetrachloromethane) & 5 & 87 & 123 & 114 \\
\hline Chlorobenzene & 5 & 94 & 104 & 97 \\
\hline Chloroethane & 5 & 81 & 117 & 115 \\
\hline Chloroform (Trichloromethane) ${ }^{1}$ & 5 & 84 & 131 & 119 \\
\hline Chloromethane & 5 & 80 & 115 & 100 \\
\hline 3-Chloropropene & 5 & 94 & 119 & 114 \\
\hline 2-Chlorotoluene & 5 & 95 & 108 & 101 \\
\hline 4-Chlorotoluene & 5 & 95 & 110 & 98 \\
\hline Dibromochloromethane & 5 & 99 & 117 & 105 \\
\hline 1,2-Dibromo-3-chloropropane (DBCP) & 5 & 92 & 125 & 102 \\
\hline 1,2-Dibromoethane (EDB) & 5 & 99 & 116 & 112 \\
\hline Dibromomethane & 5 & 94 & 125 & 115 \\
\hline 1,2-Dichlorobenzene & 5 & 97 & 120 & 117 \\
\hline 1,3-Dichlorobenzene & 5 & 90 & 115 & 104 \\
\hline 1,4-Dichlorobenzene & 5 & 89 & 107 & 104 \\
\hline trans-1,4-Dichloro-2-butene & 5 & 97 & 111 & 104 \\
\hline Dichlorodifluoromethane (CFC-12) & 5 & 53 & 117 & 97 \\
\hline 1,1-Dichloroethane $(1,1-D C A)^{1}$ & 5 & 92 & 120 & 117 \\
\hline 1,2-Dichloroethane (1,2-DCA ) & 5 & 88 & 124 & 122 \\
\hline 1,1-Dichloroethene (1,1-DCE) & 5 & 93 & 105 & 103 \\
\hline cis-1,2-Dichloroethene (cis-1,2-DCE) & 5 & 97 & 113 & 106 \\
\hline trans-1,2-Dichloroethene (trans-1,2-DCE) & 5 & 93 & 121 & 112 \\
\hline 1,2-Dichloropropane & 5 & 90 & 110 & 102 \\
\hline 1,3-Dichloropropane & 5 & 99 & 117 & 110 \\
\hline 2,2-Dichloropropane & 5 & 83 & 95 & 92 \\
\hline 1,1-Dichloropropene & 5 & 82 & 103 & 93 \\
\hline cis-1,3-Dichloropropene & 5 & 83 & 98 & 89 \\
\hline trans-1,3-Dichloropropene & 5 & 84 & 98 & 92 \\
\hline Diethyl ether & 5 & 100 & 124 & 114 \\
\hline Diisopropyl ether (DIPE) ${ }^{1}$ & 5 & 88 & 119 & 108 \\
\hline
\end{tabular}


Table A5A. Quality-control summary for matrix-spike recoveries of volatile organic compounds (VOC) in samples collected for the Borrego Valley, Central Desert, and Low-Use Basins of the Mojave and Sonoran Deserts (CLUB) Groundwater Ambient Monitoring and Assessment (GAMA) study, California, December 2008 to March 2010.—Continued

[A cceptable recovery range is between 70 and 130 percent]

\begin{tabular}{|c|c|c|c|c|}
\hline Constituent & $\begin{array}{l}\text { Number of } \\
\text { spike } \\
\text { samples }\end{array}$ & $\begin{array}{c}\text { Minimum } \\
\text { recovery } \\
\text { (percent) }\end{array}$ & $\begin{array}{c}\text { Maximum } \\
\text { recovery } \\
\text { (percent) }\end{array}$ & $\begin{array}{l}\text { Median } \\
\text { recovery } \\
\text { (percent) }\end{array}$ \\
\hline Ethylbenzene & 5 & 80 & 97 & 91 \\
\hline Ethyl tert-butyl ether (ETBE) & 5 & 83 & 110 & 97 \\
\hline Ethyl methacrylate & 5 & 85 & 105 & 99 \\
\hline 0 -Ethyl toluene (1-Ethyl-2-methyl benzene) & 5 & 82 & 97 & 90 \\
\hline Hexachlorobutadiene & 5 & 65 & 98 & 86 \\
\hline Hexachloroethane & 5 & 83 & 119 & 108 \\
\hline 2-H exanone (n-Butyl methyl ketone) & 5 & 90 & 130 & 108 \\
\hline Iodomethane (M ethyl iodide) & 5 & 111 & 137 & 125 \\
\hline Isopropylbenzene & 5 & 78 & 98 & 89 \\
\hline 4-Isopropyl-1-methyl benzene & 5 & 82 & 102 & 86 \\
\hline M ethyl acrylate & 5 & 101 & 121 & 116 \\
\hline M ethyl acrylonitrile & 5 & 105 & 137 & 120 \\
\hline M ethyl tert-butyl ether (MTBE) ${ }^{1}$ & 5 & 103 & 117 & 109 \\
\hline M ethyl iso-butyl ketone (MIBK) & 5 & 84 & 114 & 102 \\
\hline M ethylene chloride (Dichloromethane) & 5 & 86 & 116 & 110 \\
\hline M ethyl ethyl ketone (2-butanone, M EK ) & 5 & 103 & 194 & 111 \\
\hline M ethyl methacrylate & 5 & 83 & 102 & 100 \\
\hline N aphthal ene & 5 & 81 & 104 & 90 \\
\hline Perchloroethene (PCE, Tetrachloroethene) ${ }^{1}$ & 5 & 98 & 126 & 104 \\
\hline n-Propylbenzene & 5 & 85 & 98 & 88 \\
\hline Styrene & 5 & 70 & 97 & 88 \\
\hline 1,1,1,2-Tetrachloroethane & 5 & 92 & 117 & 113 \\
\hline 1,1,2,2-Tetrachloroethane & 5 & 90 & 120 & 110 \\
\hline Tetrahydrofuran & 5 & 94 & 124 & 109 \\
\hline 1,2,3,4-Tetramethylbenzene & 5 & 74 & 101 & 87 \\
\hline 1,2,3,5-Tetramethylbenzene & 5 & 81 & 117 & 91 \\
\hline Toluene & 5 & 92 & 102 & 98 \\
\hline 1,2,3-Trichlorobenzene & 5 & 95 & 110 & 103 \\
\hline 1,2,4-Trichlorobenzene & 5 & 81 & 94 & 89 \\
\hline 1,1,1-Trichloroethane (1,1,1-TCA ) & 5 & 90 & 127 & 117 \\
\hline 1,1,2-Trichloroethane (1,1,2-TCA) & 5 & 102 & 122 & 110 \\
\hline Trichloroethene (TCE) ${ }^{1}$ & 5 & 90 & 105 & 100 \\
\hline Trichlorofluoromethane (CFC-11) & 5 & 83 & 129 & 118 \\
\hline 1,2,3-Trichloropropane (1,2,3-TCP) & 5 & 95 & 129 & 106 \\
\hline Trichlorotrifluoroethane (CFC-113) & 5 & 76 & 134 & 98 \\
\hline 1,2,3-Trimethyl benzene & 5 & 92 & 119 & 99 \\
\hline $1,2,4$-Trimethylbenzene ${ }^{1}$ & 5 & 84 & 108 & 95 \\
\hline 1,3,5-Trimethylbenzene & 5 & 81 & 99 & 92 \\
\hline Vinyl bromide (B romoethene) & 5 & 88 & 123 & 96 \\
\hline 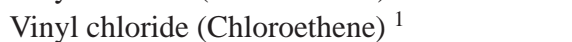 & 5 & 76 & 138 & 115 \\
\hline $\mathrm{m}$ - and $\mathrm{p}$-Xylene & 5 & 85 & 104 & 100 \\
\hline $0-X y l e n e$ & 5 & 89 & 97 & 89 \\
\hline
\end{tabular}

\footnotetext{
${ }^{1}$ Constituents detected in groundwater samples.
} 
Table A5B. Quality-control summary for matrix-spike recoveries of pesticides and pesticide degradates in samples collected for the Borrego Valley, Central Desert, and Low-Use Basins of the Mojave and Sonoran Deserts (CLUB) Groundwater Ambient Monitoring and Assessment (GAMA) study, California, December 2008 to March 2010.

[A cceptable recovery range is between 70 and 130 percent]

\begin{tabular}{|c|c|c|c|c|}
\hline Constituent & $\begin{array}{c}\text { Number of } \\
\text { spike } \\
\text { samples }\end{array}$ & $\begin{array}{l}\text { Minimum } \\
\text { recovery } \\
\text { (percent) }\end{array}$ & $\begin{array}{c}\text { Maximum } \\
\text { recovery } \\
\text { (percent) }\end{array}$ & $\begin{array}{c}\text { Median } \\
\text { recovery } \\
\text { (percent) }\end{array}$ \\
\hline Alachlor & 5 & 73 & 116 & 90 \\
\hline A trazine $^{1}$ & 5 & 80 & 118 & 88 \\
\hline A zinphos-methyl & 5 & 67 & 116 & 83 \\
\hline Carbaryl & 5 & 66 & 156 & 103 \\
\hline 2-Chloro-2,6-diethylacetanilide & 5 & 71 & 125 & 84 \\
\hline 4-Chloro-2-methylphenol & 5 & 34 & 80 & 70 \\
\hline Chlorpyrifos & 5 & 54 & 90 & 63 \\
\hline Chlorpyrifos-oxon & 5 & 16 & 40 & 37 \\
\hline Desulfinylfipronil & 5 & 65 & 128 & 93 \\
\hline Desulfinylfipronil amide & 5 & 71 & 112 & 79 \\
\hline Diazinon & 5 & 73 & 105 & 82 \\
\hline 3,4-Dichloroaniline ${ }^{1}$ & 5 & 61 & 102 & 70 \\
\hline Dichlorvos & 5 & 5 & 51 & 14 \\
\hline Dicrotophos & 5 & 17 & 76 & 32 \\
\hline Dieldrin $^{1}$ & 5 & 65 & 93 & 77 \\
\hline 2,6-Diethylaniline & 5 & 86 & 95 & 95 \\
\hline Dimethoate & 5 & 30 & 65 & 42 \\
\hline Ethion & 5 & 50 & 95 & 65 \\
\hline Fipronil sulfone & 5 & 56 & 74 & 67 \\
\hline Fonofos & 5 & 62 & 103 & 80 \\
\hline Hexazinone & 5 & 48 & 95 & 69 \\
\hline Iprodione & 5 & 50 & 101 & 75 \\
\hline Isofenphos & 5 & 61 & 118 & 110 \\
\hline Malaoxon & 5 & 53 & 112 & 108 \\
\hline M alathion & 5 & 56 & 116 & 108 \\
\hline M etalaxyl & 5 & 73 & 146 & 114 \\
\hline M ethidathion & 5 & 67 & 103 & 90 \\
\hline M etolachlor ${ }^{1}$ & 5 & 68 & 103 & 93 \\
\hline M etribuzin & 5 & 60 & 110 & 83 \\
\hline M yclobutanil & 5 & 63 & 134 & 80 \\
\hline 1-Naphthol & 5 & 11 & 23 & 19 \\
\hline Paraoxon-methyl & 5 & 30 & 80 & 65 \\
\hline Parathion-methyl & 5 & 60 & 106 & 70 \\
\hline
\end{tabular}


Table A5B. Quality-control summary for matrix-spike recoveries of pesticides and pesticide degradates in samples collected for the Borrego Valley, Central Desert, and Low-Use Basins of the Mojave and Sonoran Deserts (CLUB) Groundwater Ambient Monitoring and Assessment (GAMA) study, California, December 2008 to March 2010—Continued

[A cceptable recovery range is between 70 and 130 percent]

\begin{tabular}{lcccc}
\hline Constituent & $\begin{array}{c}\text { Number of } \\
\text { spike } \\
\text { samples }\end{array}$ & $\begin{array}{c}\text { Minimum } \\
\text { recovery } \\
\text { (percent) }\end{array}$ & $\begin{array}{c}\text { Maximum } \\
\text { recovery } \\
\text { (percent) }\end{array}$ & $\begin{array}{c}\text { Median } \\
\text { recovery } \\
\text { (percent) }\end{array}$ \\
\hline Pendimethalin & 5 & 59 & 107 & 88 \\
cis-Permethrin & 5 & 36 & 66 & 50 \\
Phorate & 5 & 34 & 81 & 59 \\
Phorate oxon & 5 & 67 & 122 & 95 \\
Phosmet & 5 & 7 & 89 & 35 \\
Phosmet oxon & 5 & 12 & 78 & 40 \\
Prometon & 5 & 66 & 103 & 79 \\
Prometryn & 5 & 67 & 118 & 93 \\
Pronamide (Propyzamide) & 5 & 71 & 111 & 80 \\
Simazine & 5 & 72 & 118 & 87 \\
Tebuthiuron & 5 & 94 & 205 & 149 \\
Terbufos & 5 & 60 & 95 & 67 \\
Terbufos oxon sulfone & 5 & 44 & 154 & 102 \\
Terbuthylazine & 5 & 80 & 116 & 92 \\
Tribufos & 5 & 34 & 66 & 57 \\
Trifluralin & 5 & 60 & 94 & 69 \\
\hline
\end{tabular}

${ }^{1}$ Constituents detected in groundwater samples.

Table A5C. Quality-control summary for matrix-spike recoveries of constituents of special interest in samples collected for the Borrego Valley, Central Desert, and Low-Use Basins of the Mojave and Sonoran Deserts (CLUB) Groundwater Ambient Monitoring and Assessment (GAMA) study, California, December 2008 to March 2010.

[A cceptable recovery range is between 70 and 130 percent]

\begin{tabular}{lcccc}
\hline \multicolumn{1}{c}{ Constituent } & $\begin{array}{c}\text { Number of } \\
\text { spike } \\
\text { samples }\end{array}$ & $\begin{array}{c}\text { Minimum } \\
\text { recovery } \\
\text { (percent) }\end{array}$ & $\begin{array}{c}\text { Maximum } \\
\text { recovery } \\
\text { (percent) }\end{array}$ & $\begin{array}{c}\text { Median } \\
\text { recovery } \\
\text { (percent) }\end{array}$ \\
\hline Perchlorate ${ }^{1}$ & 1 & 113 & 294 \\
N-nitrosodimethylamine (NDMA) & 2 & 120 & 116.5 \\
\hline
\end{tabular}

\footnotetext{
${ }^{1}$ Constituent detected in groundwater samples.

${ }^{2} \mathrm{M}$ edian recovery represented by the single spike value.
} 


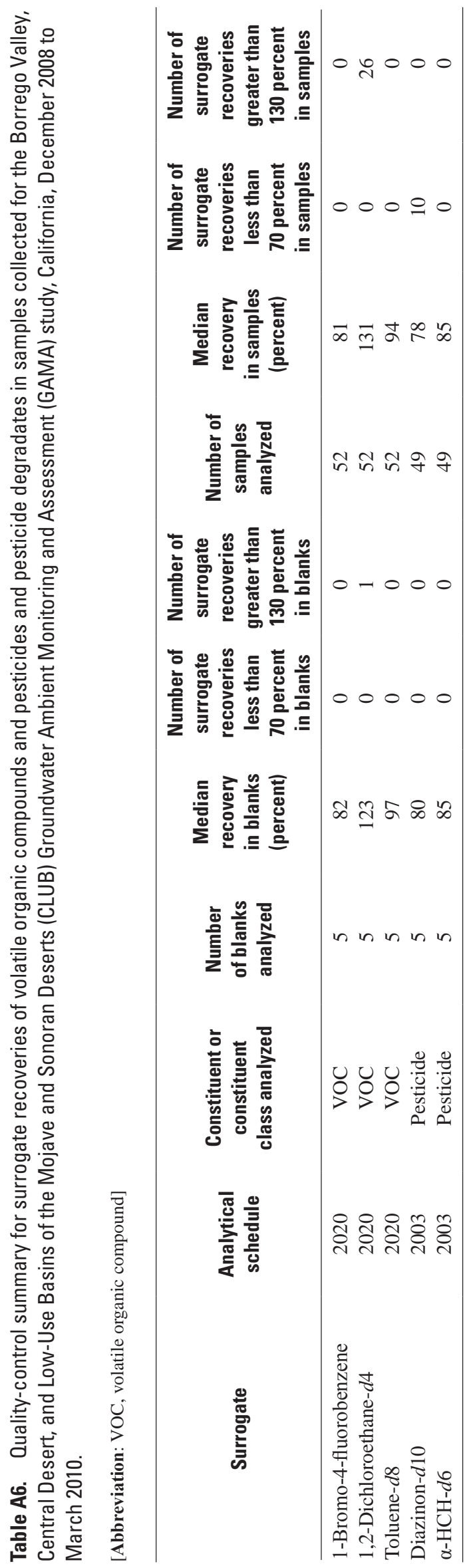


Publishing support provided by the U.S. Geological Survey Science

Publishing Network, Sacramento, Tacoma, and Raleigh Publishing Service Centers

For more information concerning the research in this report, contact the

Director, California Water Science Center

U.S. Geological Survey

6000 J Street, Placer Hall

Sacramento, California 95819

http://ca.water.usgs.gov 
